\title{
THIS IS (NOT) A LANEWAY. ENVISIONING TORONTO'S FUTURE MID-BLOCK COMMUNITIES.
}

\author{
by \\ Maya Janikowski \\ BCD, BEDS Dalhousie University, 2008 \\ A design Thesis Project \\ presented to Ryerson University \\ in partial fulfillment of the \\ requirements for the degree of \\ Master of Architecture \\ in the Program of
}

Architecture

Toronto, Ontario, Canada, 2011

(C) Maya Janikowski, 2011 



\section{Author's Declaration}

I hereby declare that I am the sole author of this thesis project. I authorize Ryerson University to lend this thesis project to other institutions or individuals for the purpose of scholarly research.

Maya Janikowski

I further authorize Ryerson University to reproduce this thesis project by photocopying or by other means, in total or in part, at the request of other institutions or individuals for the purpose of scholarly research.

Maya Janikowski 



\title{
THIS IS (NOT) A LANEWAY. ENVISIONING TORONTO’S FUTURE MID-BLOCK COMMUNITIES.
}

\author{
By. Maya Janikowski \\ MArch. Department of Architecture. Ryerson University.
}

\begin{abstract}
The City of Toronto's laneway network is an untapped resource whose potential for residential development can support unique architectural opportunities and promote much needed sustainable and livable urban communities. Residential laneway development, as a form of infill, has the potential to increase the City's density without threatening the existing City fabric while providing a highly demanded housing typology.

This thesis is structured around three intentions. It attempts to prove that laneway housing development is an opportunity for alleviating Toronto's housing requirements; imagines what this housing typology would look like in the context of Toronto's urban form; and explores the evolution of the laneway housing form in the entire laneway context. Arguing that when designed from this perspective, the laneway housing form has the potential to foster the growth of strong and desirable mid-block communities.
\end{abstract}





\section{Acknowledgments}

Firstly, I would like to thank the Ryerson University Graduate Program for their support and funding of my graduate education.

To my mother, thank you for encouraging me down the path of Architectural education and believing in me throughout the entire process.

To my father, thank you for reassuring me of my potentials and giving me the strength to continue in my times of doubt.

To my boyfriend, and my friends, thank you for your support, love and companionship during the stress filled late nights.

To Brigitte Shim and Howard Sutcliffe for designing the house that inspired this thesis and to David Donnelly for introducing it to me.

To Terence Van Elslander, Graeme Perry, Chris Chopik and Michael Vaughan, thank you for taking the time to share your knowledge of laneway housing with me, and to John Twomey for feeding my passion on the subject.

A special thank you to Miljana Horvat, for your dedication and support throughout this past year. 



\section{Table of Contents}

Abstract $\quad \mathrm{v}$

List of Tables xiii

List of Figures $\quad$ XV

The House That Started It All 1

An Invitation 3

Introduction $\quad 5$

$\begin{array}{ll}\text { Motivation } & 6\end{array}$

$\begin{array}{ll}\text { Research Methodology } & 7\end{array}$

$\begin{array}{ll}\text { Review of Literature } & 9\end{array}$

$\begin{array}{ll}\text { The Changing Face of Urban Growth } & 9\end{array}$

$\begin{array}{ll}\text { Opportunity in Existing Urban Form } & 11\end{array}$

$\begin{array}{ll}\text { The Changing Face of Housing Form } & 16\end{array}$

An Argument for Laneway Housing in Toronto 21

Laneway and Laneway Housing History $\quad 21$

The Current State of Toronto's Laneways 23

Toronto's Laneway Typologies 25

Toronto's Laneway Housing Potential 26

Toronto's Deepening Growth Challenges $\quad 27$

Sustainable Development Initiatives $\quad 30$

Creating Great Neighbourhoods through Densification 31

Creating Walkable Neighbourhoods 31

Supporting Housing Choice and Affordability 32

Helping Expand Transportation Choices 33

Supporting Community Fiscal Health 33

Protecting The Environment 34

Toronto Laneway Interest and Recognition 35

Toronto's Laneway Housing Policy 37

Learning from Precedent 38 

Prove - It Can Be Done $\quad 41$

Urban Form (Lot Size) Restrictions $\quad 43$

Density 44

Housing Density Potential $\quad 46$

$\begin{array}{ll}\text { Scale } & 50\end{array}$

Height Determination Through Shadow Studies 51

Privacy / Overlook 54

Open Space / Day Lighting 55

Imagine - What it Could Look Like $\quad 57$

Site One - The Micro House 58

Site Two - The Family Home and The Live / Work Home 61

Site Three - The Townhouse (Row House) 65

Explore - Evolution and Organic Growth 71

A Comment on Existing Laneway Housing Form 72

$\begin{array}{ll}\text { Site Typology Analysis } & 74\end{array}$

$\begin{array}{ll}\text { Site Typology Development } & 75\end{array}$

$\begin{array}{ll}\text { Site Form Development } & 76\end{array}$

$\begin{array}{ll}\text { Final Design Manifestation } & 79\end{array}$

Proposed Sections $\quad 80$

Proposed Site Ground Floor Plan 81

A Design Tour $\quad 82$

Proposed North Elevations and Building Plans $\quad 85$

$\begin{array}{ll}\text { Proposed South Elevations and Building Plans } & 87\end{array}$

$\begin{array}{lr}\text { Further Considerations } & 89\end{array}$

$\begin{array}{ll}\text { Final Thoughts } & 93\end{array}$

$\begin{array}{ll}\text { Table Credits } & 97\end{array}$

Figure Credits $\quad 99$

$\begin{array}{ll}\text { Works Cited } & 113\end{array}$

$\begin{array}{ll}\text { Extended Reference List } & 117\end{array}$ 



\section{List of Tables}

* Table credits can be found on page 97.

2-01 Number and Length of City of Toronto public laneways. 24

2-02 Greater Toronto Area Forecasted Population. 29

2-03 City of Toronto's Housing Surplus and Shortfall. 29

2-04 Toronto neighbourhoods proximity to daily amenities. 32

2-05 Toronto G.H.G emission from weekday urban car trips. 34

2-06 Toronto laneway field research survey. 35 



\section{List of Figures}

${ }^{*}$ Figure credits can be found on page 99.

i-01 7 Leslie Garden Lane. Shim Sutcliffe Architects. 2

i-02 to i-05 Laneway Entrances, Toronto. 3

i-06 Residential Suburban Sprawl. 4

i-07 Toronto's High-Rise/High-Density Developments. 4

i-08 to i-11 Toronto's Laneway House Images. 4

1-01 A Toronto Laneway. 8

1-02 Trenton Terrace (laneway), Toronto. 8

1-03 Capris, Italy. 11

1-04 Markham New Urbanism Plaza Design. 11

1-05 Sherbourne Lanes section. 12

1-06 Sherbourne Lanes Street Fronting Character. 12

1-07 Sherbourne Lanes Aerial Photograph. 12

1-08 Belgrave Place (mews) London, England. 13

1-09 London Mews, Site Context Plan. 13

1-10 Washington Mews, NY, New York. 13

1-11 A Typical North American Residential Laneway. 14

1-12 Woonerf Street Design Example. 14

1-13 Pasadena, California, Laneway Entrance. 14

1-14 Warren Place, Garden Mews, NY, New York. 14

1-15 Woonerf Street Design Example. 15

1-16 Woonerf Design Principles Plan. 15

1-17 Chicago's Green Alleys Program. 15

1-18 Baltimore's Alley Gating and Greening Ordinance. 15

1-19 Vancouver's, Mole Hill. 15

1-20 Ancillary Dwelling Diagram. 16

1-21 Ancillary Dwelling Lot Design Considerations. 16

1-22 Vancouver's Laneway Housing Illustrative Examples. 16

1-23 Seattle's A Guide to Building a Backyard Cottage. 16

1-24 Vancouver's Laneway Houses. 17

1-25 Seattle's Backyard Cottages. 17

1-26 A Study of Laneway Housing in Toronto, Cover Image. 18

1-27 Site Unseen, Cover Image. 18 

2-01 Aerial photograph of Toronto's laneways. 20

2-02 Pre-Amalgamated City of Toronto Map In Context. 21

2-03 Toronto's Historical Urban Form Development. 21

2-04 Emergence of the City of Toronto`s Laneway System. 21

2-05 to 2-11 Toronto's Historical Laneway Photographs. 22

2-12 Toronto's Existing Laneway Frequency Map. 23

2-13 Toronto's Laneway System in Relation to Lake Ontario. 24

2-14 Current State of Toronto`s Laneways. 24

2-15 Laneway Typologies. 25

2-16 A Typical Laneway Section. 25

2-17 Potential Laneway Housing Sites (study area) Toronto. 26

2-18 Toronto Suburban Sprawl. 27

2-19 City of Apartments. 27

2-20 Toronto's Limited Ground Related Housing Stock. 27

2-21 The Uni-Centered City by Victor Lazzaro, 1978. 27

2-22 Toronto as the Uni-Centered City. 27

2-23 Toronto's Built Up Area. 29

2-24 Intensification Diagram. 30

2-25 A Toronto Established Neighbourhood. 31

2-26 Toronto Established Residential Neighbourhood. 31

2-27 Laneway Entrance off of Harbord Street, Toronto. 31

2-28 to 2-30 Toronto's High-Density/Mid to High-Rise Developments. 32

2-31 Laneway Townhouses, by Van Elslander Carter Arch. 32

2-32 BixiBike, Toronto. 33

2-33 AutoShare, Toronto. 33

2-34 Highway Infrastructure, Toronto. 33

2-35 Laneway Infrastructure, Toronto. 33

2-36 Alley Way Love Affair Tour Maps. 35

2-37 to 2-40 Toronto Urban Design Awards. 36

2-41 St. James Town Development, Toronto. 37

2-42 By-law 436-86 Section 4 (11)a . 37

3-01 Old (Pre-Amalgamated) City of Toronto Map. 42

3-02 Design Exploration Site Map. 42

3-03 Lot Size Restriction Comparison Exploration Plans. 43

3-04 Sherbourne Lanes, Density Distribution Comparison. 44

3-05 Laneway Lot Severance Options. 44 


4-13, 4-14 Site three Existing Laneway Houses. 65

4-15 Site Three Block Plan. 65

4-16 Curzon Street Elevation. 65

4-17 Site Three Site and Building Plans and Section. 66

4-18 Site Three Existing Lane Context. 67

4-19 Site Three Proposed Lane Context. 67

4-20 Site Two Block Plan Containing all L.W.H. Prototypes. 68

4-21 Laneway View One. 69

4-22 Laneway View Two. 69

4-23 Laneway View One - Constriction Diagram. 69

4-24 Laneway View Two - Constriction Diagram. 69

5-01 1 Ways Lane Sketch. 73

5-02 7 Leslie Garden Lane Sketch.

5-03 40R Shaftesbury Sketch. 73

5-04 Carlton Village Laneway House Sketch. 73

5-05 Final Design. Aerial View North East. 78

5-06 Final Design. Proposed Site Plan. 79

5-07 View From Roof Terrace. 80

5-08 Proposed Sections. 80

5-09 Proposed Ground Floor Site Plan. 81

5-10 A Design Tour. 83

5-11 Estate House Interior View. 84

5-12 Slice House Interior View. 84

5-13 Proposed North Elevations and Building Plans. 85

5-14 Live / Work House Interior View. 86

5-15 Townhouse Interior View. 86

5-16 Proposed South Elevations and Building Plans. 87

5-17 Proposed Lane View West. 88

5-18 Proposed Lane View East. 91

5-19 Proposed Lane View North West. 92 


$$
\text { THIS SNOT) A LANEWAY }
$$

1. Prove it can be done.

2 MAGINE. - What it could look like

3. EPLORE. - evolution -organic growth.

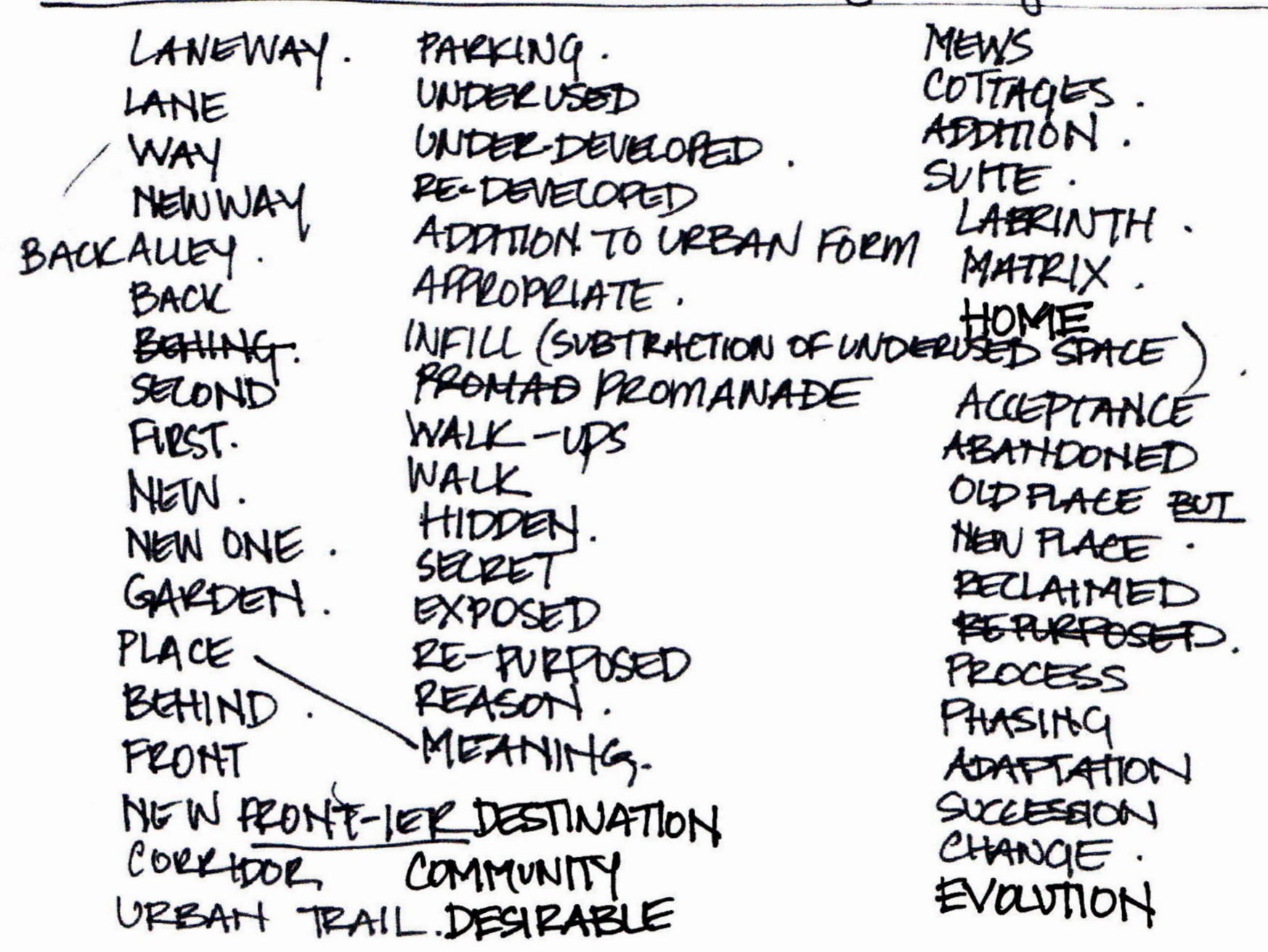

I SOMETHING THAT EXISTS BUT HAS YET TO BE RECOQNRED for IIS POTENTIAL'

$-x x i i-$ 


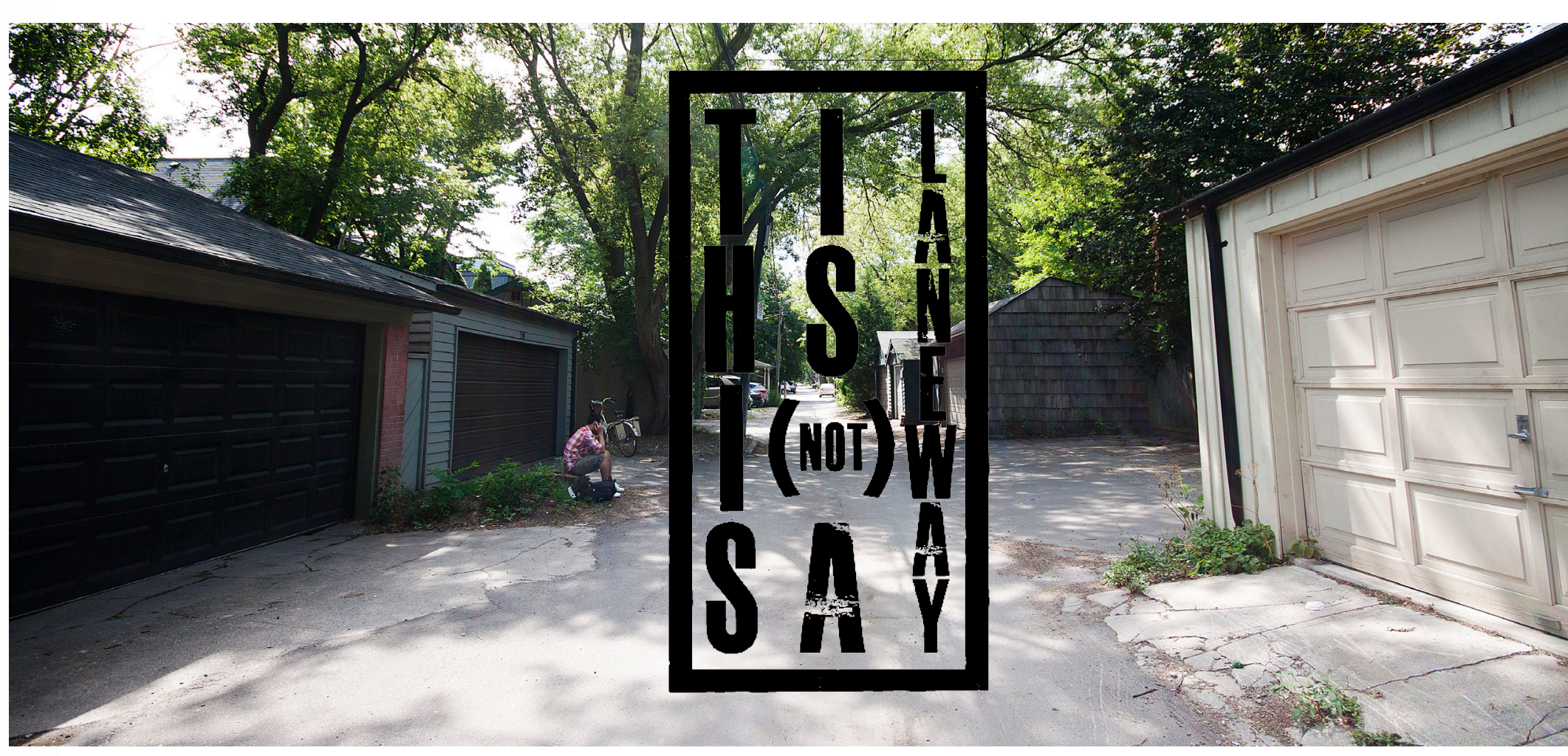




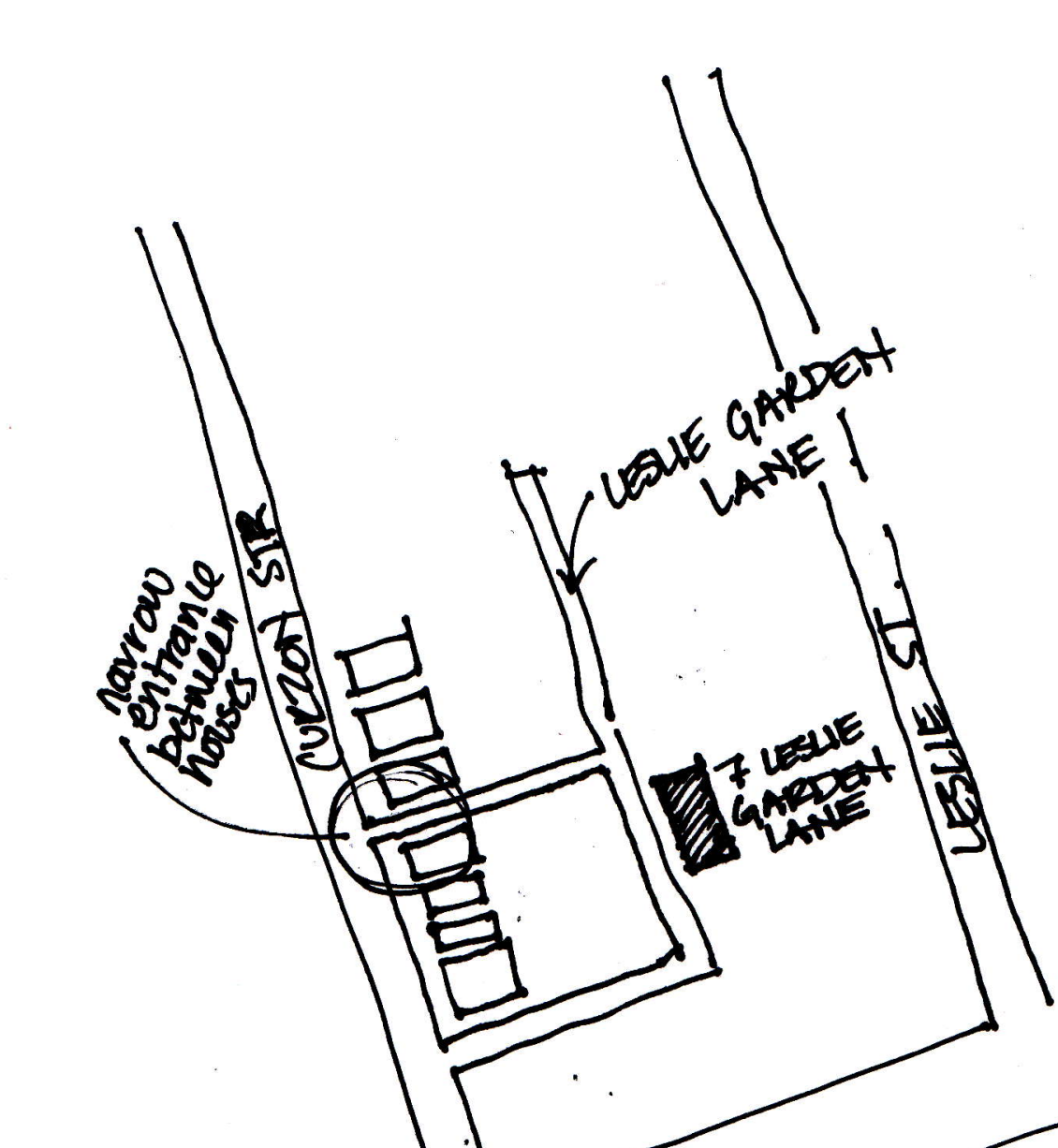




\section{The House That Started It All}

I was first introduced to laneway housing through a family friend who lives in Toronto's east end. One day after dinner he insisted that my mother and I join him for a walk because he wanted to show me something. We walked north from Queen Street along Curzon Street. The area immediately changes from bustling gentrified commercial to a quaint single family residential neighbourhood. Some twenty paces north of Queen Street our friend David turned right off of Curzon Street and began walking towards a narrow driveway opening between two houses. Intrigued by the assumed detour, we followed him with a feeling of wrong doing as if we were trespassing onto someone's private property.

The aromas from the adjacent houses, seeping out of the kitchen exhausts, engulfed us as we moved through the narrow space. As we made our way closer toward the inner block and away from the street, the noises of urban life dissipated as we emerged into a new territory. It was not someone's private yard, but an open space separated from the residences' back yards by fences and garages. A place behind place; an unknown space that exists mid block unbeknownst to those passersby who decide to ignore the invitation and stick to the public sidewalk. Consumed with greenery and parked cars, Leslie Garden Lane exists as if it anticipates visitors but only gets the occasional block resident who uses the space as rear parking access.

Distracted by the character of the lane as it turns left and runs in behind the main houses, I failed to notice a house tucked away to the right. Consumed with greenery growing along the walls that surround it, dropped into the ground, I had to look twice to make sure I was seeing it correctly. Was I being shown a private residence in this tucked away place? I had no idea such things existed in the City of Toronto. An excitement overwhelmed me, like the one that you get when you stumble upon a hidden courtyard or majestic street in a European city and wish that North America had the character and urban form to encourage such unique development.

THIS IS (NOT) A LANEWAY. ENVISIONING TORONTO'S FUTURE MID-BLOCK COMMUNITIES. September 16, 2011. By: Maya Janikowski. Supervisor: Miljana Horvat. 


\section{That day I fell in love with the concept of laneway housing.}

The creation by Shim Sutcliffe Architects on Leslie Garden Lane ignited an excitement in me that stayed with me as I embarked on my Master of Architectural studies.

It has fed my belief that Toronto's laneways hold incredible opportunities and as Architects we have the privilege to imagine these spaces for their potentials. Hence, with architecture as a guiding tool, this thesis is an exploration of these opportunities, arguing that the City of Toronto should allow for laneway development 'by right' and encourage the growth of mid block communities that promote unique built form and sustainable practices.

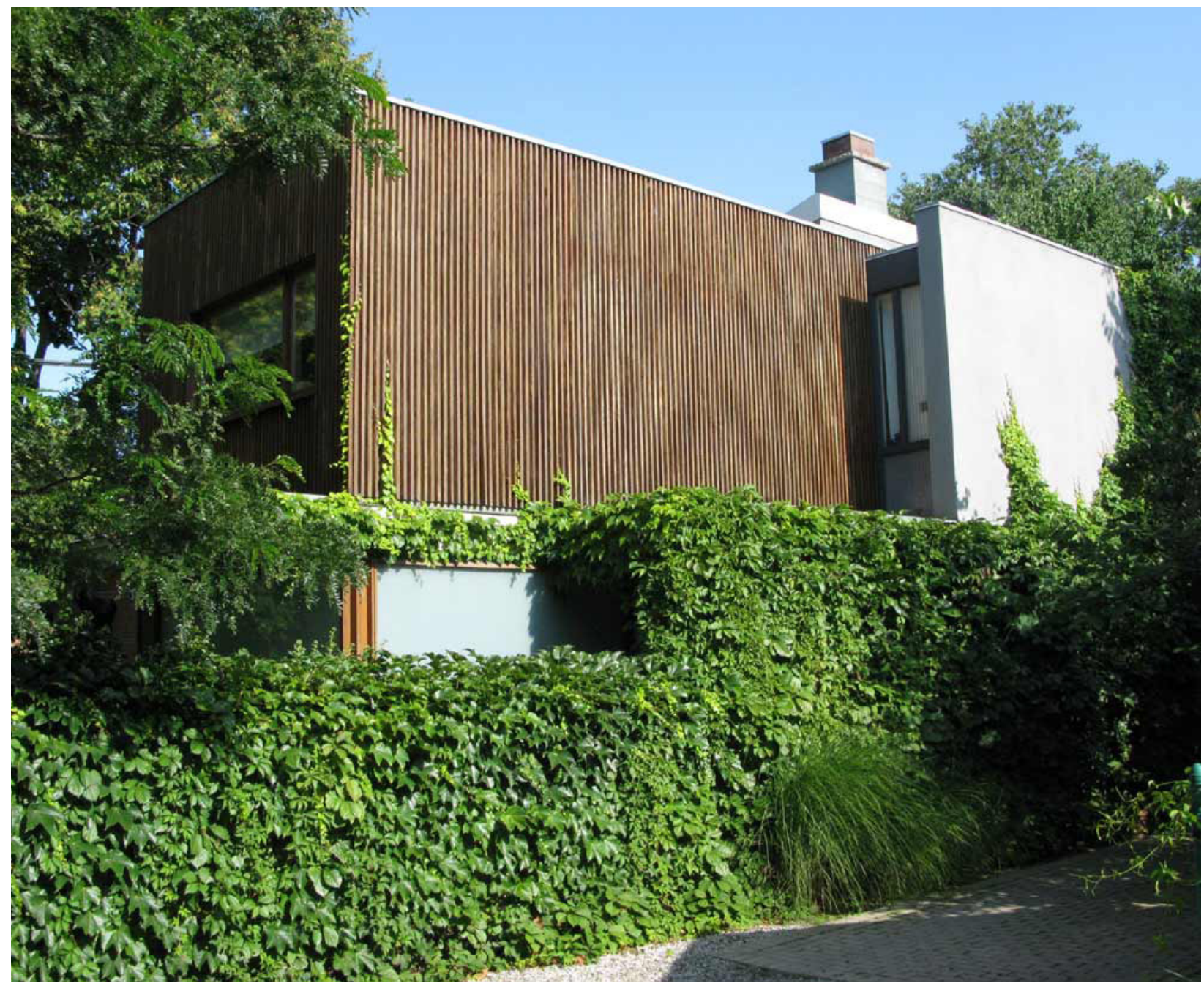

Figure i-01 7 Leslie Garden Lane. Shim Sutcliffe Architects. 


\section{An Invitation}

One can spend years living in this city and be oblivious of their existence, walking day in and day out and pass right by them. However, if one day you decide to pull your eyes away from the commonalities of the main street, you may catch a glimpse of them in the corner of your eye. They are,

\section{traditionally the paths less taken.}

(Jeremy Oberstein)

They emerge as breaks in the street front inviting those adventurous to explore. Explore them if you dare.

\section{Satisfy your primordial interest.}

(Jeremy Oberstein)

Allow your curiosity to introduce you to the forgotten parts of the city:

\section{a portal to another world. (Elaine Layabout) ${ }^{*}$}

These silent and empty places long for a reintroduction and an energy of presence. Explore. Explore and you may find the most interesting parts of the city in them. Hidden places that only a fortunate few know of. Explore and you may be surprised to see where they lead you or that they contain homes, communities and purpose. Explore and you may be pleasantly surprised to see these places for what they are and could be.

*Taken from Los Angeles Alleys, curated by Jeremy Oberstein (2011).
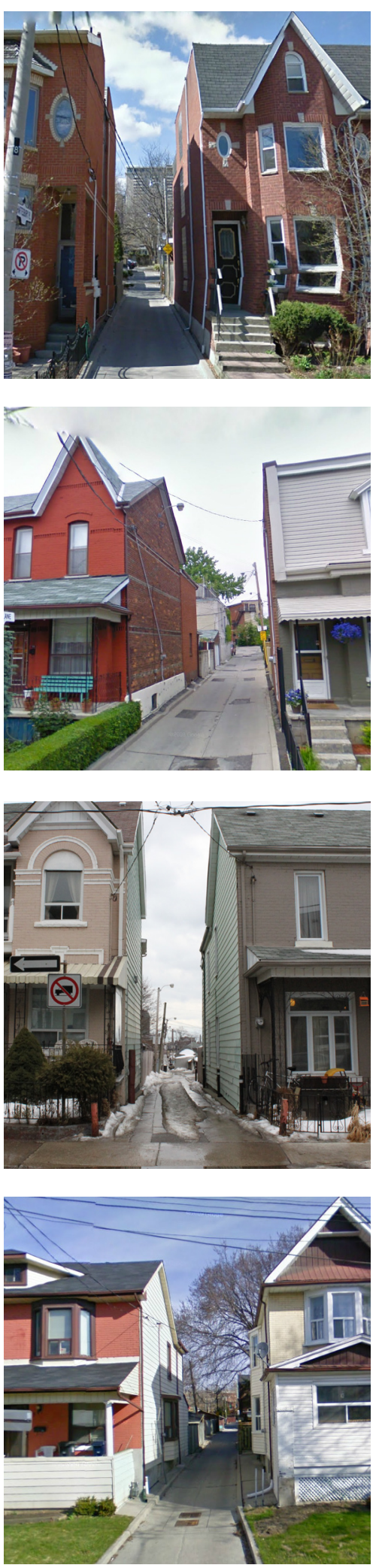

Figures i-02 - 05. 

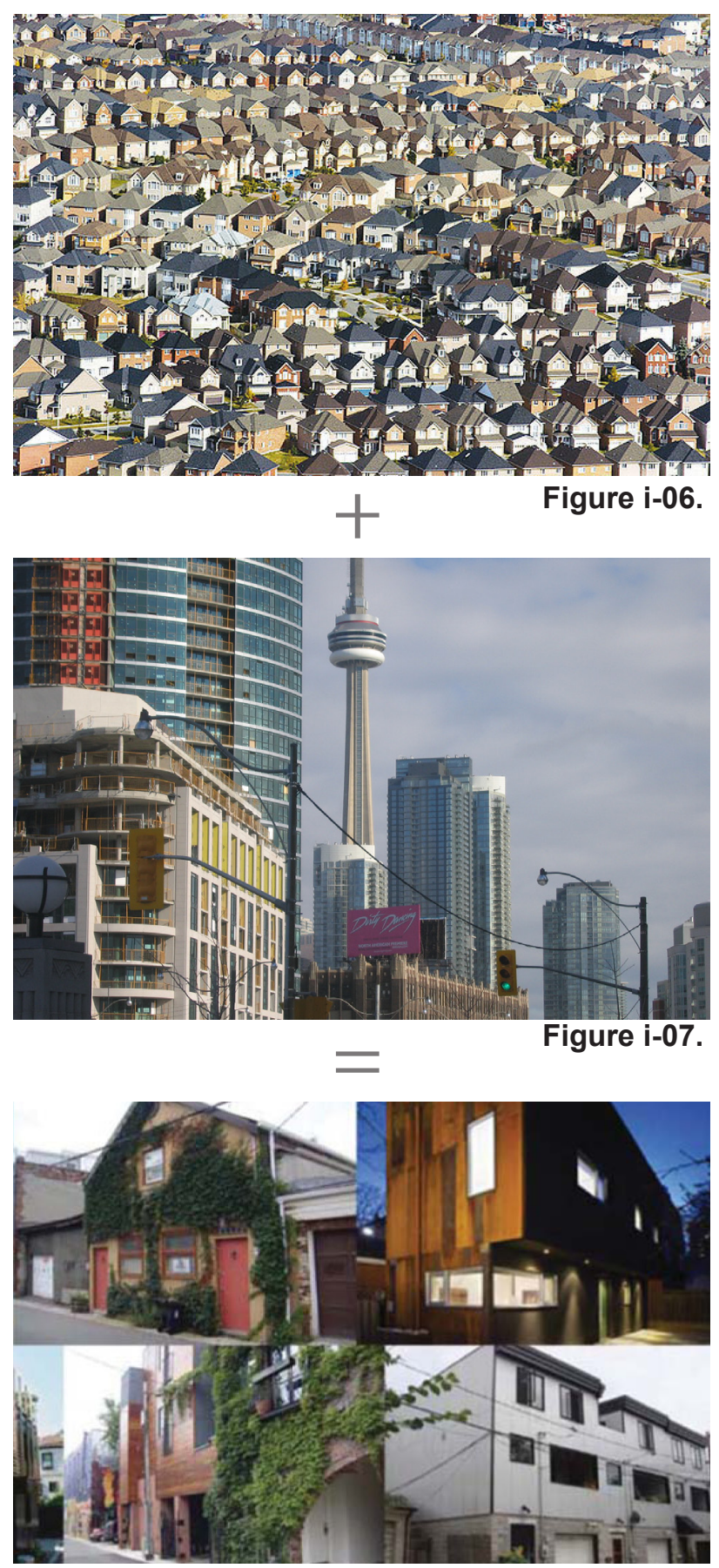

Figures (clockwise from top left) i-08 - i-11.
Laneways are an opportunity [for the City of Toronto] to mediate between two opposing trends: reconciling the desire to live downtown with the desire to live in a fully detached house.

(Shim \& Chong, 2004, p. 18) 


\section{Introduction}

Population growth has become and continues to be a serious planning issue. Presently, in an attempt to accommodate its rising population, Toronto's city center is growing skyward in the form of high rise developments and its boundaries are ever expanding outwards in the form of suburban sprawl. Cities like Toronto, whose populations are forecasted to increase significantly in the next twenty years, need to recognize unique and available opportunities in order to secure a sustainable living environment and good quality of life for their residents. Toronto's extensive laneway network is an example of one of these opportunities. The City of Toronto's laneway network is an untapped resource whose potential for residential development can support unique architectural opportunities and promote sustainable and liveable urban communities.

The City of Toronto is a burgeoning metropolis, yet at the same time, it is commonly described as a city of neighbourhoods. Ground related single family housing is in high demand in the City of Toronto and is driving up housing prices, forcing residents to chose from high-density/highrise condo living, in order to stay in the city, or the suburban lifestyle. The city is caught between these two polarized development typologies that provide quick solutions for housing. These developments are segregating people from their relationship to the streetscape and threatening the valuable Greenfield land resource. Residential laneway development, as a form of infill, has the potential to increase the city's density without threatening the existing city fabric while providing a highly demanded housing typology. 


\section{Motivation}

The problem lies in that current policy in Toronto does not allow for laneway development. Any existing residential development on laneways is either of the vernacular form or has fought through extensive zoning amendments for approval. In short, the city has turned its back on its laneways resulting in a large negative opinion of these spaces. The policy makers and residents of Toronto need to recognize these mid block networks for the opportunities they present.

These current policies, precedents and public opinion on the subject of laneway development in Toronto have inspired the guiding research questions of this thesis.

- Firstly, what opportunities exist in the development of Toronto's laneways for residential purposes?

- Secondly, can the City of Toronto's urban form support this type of development?

- And lastly, how can architecture be the driving force behind the solutions in how to create livable laneway residences that promote desirable laneway communities?

The intent of this thesis is to explore laneways through architectural means. Architecture is the art of problem solving through form and in order for laneway housing to be accepted by right negative pre-conceived notions of these places must be replaced with excitement and opportunity; a re-envisioning of space and a re-definition of place. Laneways are not only a place to store garbage and cars, but places to live, to grow, to play. They are not only a no-exit, and not only a through-way but an invitation, a destination, a community, a home. Architecture has the power to enlighten critics and prove that these spaces can support a good quality of life through attention to aesthetics, form and function, and a foundation for the growth of a community. 


\section{Research Methodology}

The design approach for this thesis was born out of research gathered on the changing face of urban form. Inspired by the writings of architects and theorists who criticize the existing urban development patterns and suggest reform in the way we plan and design our cities. Calling for the recognition that societal needs and wants are changing, and that cities contain unique vacant urban forms that should be recognized and respected for the opportunities they present. Specifically, this thesis was born out of the excitement triggered by research that recognized the specific opportunities in laneway infrastructure: opportunities for the urban renewal of these spaces and their potential opportunities for supporting housing development.

Supported by precedents, demographic trends, and environmental issues, this thesis is structured around three intentions.

Based on information gathered from A Study of Laneway Housing in Toronto (Stinson \& Van Elslander, 2003), and the City of Vancouver and Seattle's ancillary dwelling regulations, the first intention was to prove that laneway housing development is possible within Toronto's existing urban fabric.

The second intention was to imagine what this housing typology would look like in the context of Toronto's urban form.

The final intention of this thesis was born out of the conclusions and realizations of the previous two intentions. Its goal is to explore the laneway housing form, not solely on a lot by lot basis, but through its evolution in the entire laneway context, arguing that when designed from this perspective, the laneway housing form has the potential to foster the growth of strong and desirable mid-block communities. 

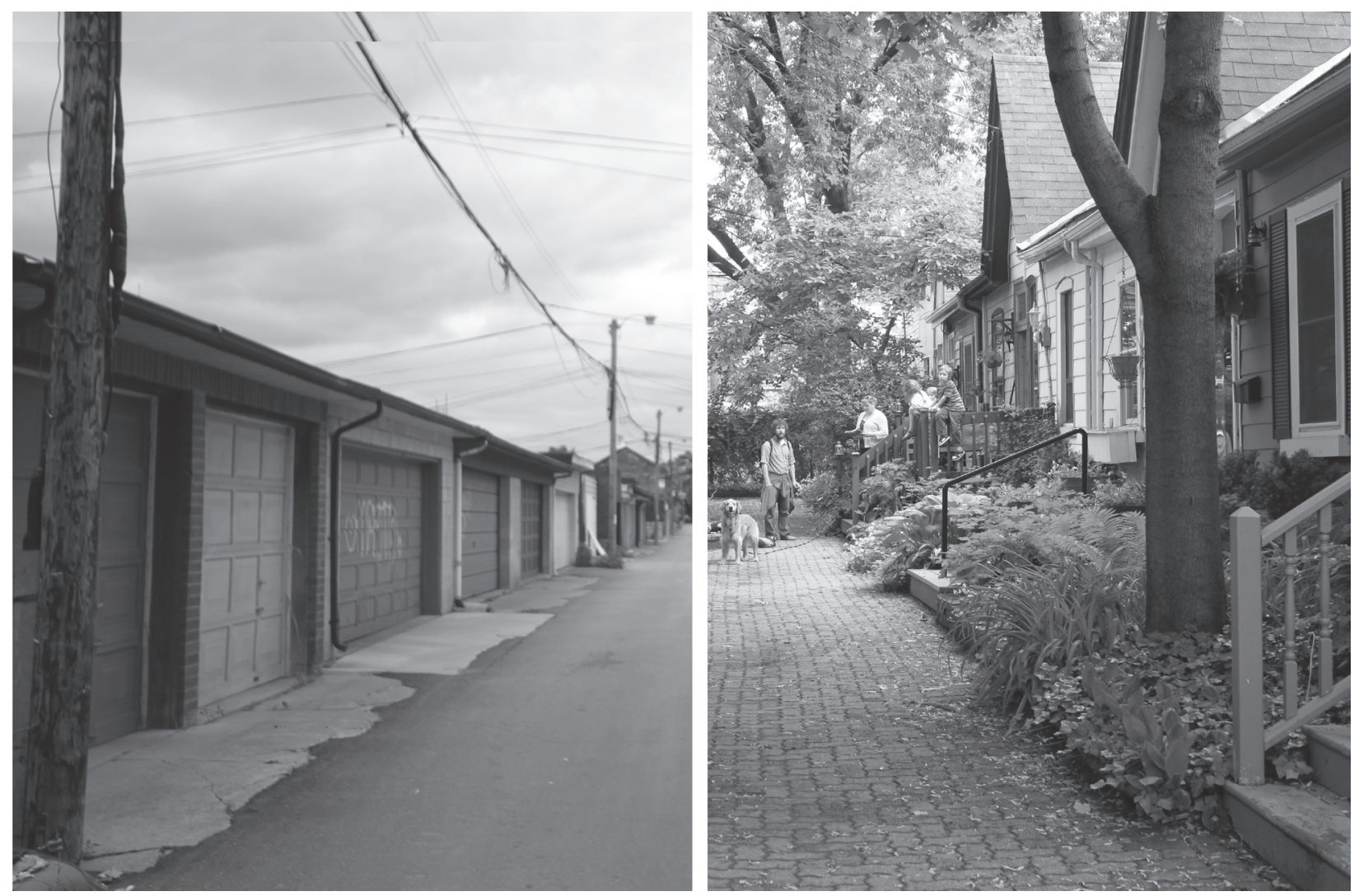

Figures 1-01, 1-02. 


\section{Review of Literature}

\section{The Changing Face of Urban Growth}

City centres used to be the hubs of all new growth. Offering employment and housing opportunities, cities attracted an influx of people from surrounding rural areas with the promise of a better life. The city's urban form adapted accordingly to support population growth and housing needs. However, the unprecedented growth in North American city centres eventually caused pressures on the urban environment. Preceding health standards and zoning regulations, that monitored density and building code standards, a manifestation of inhumane and dangerous living conditions emerged. The coming of the industrial revolution and the introduction of the automobile offered an escape from the deplorable living conditions of the city centre while providing a means to commute to work. This marked a time of major change in the urban growth of cities: from densification to sprawl. While the move to suburbia has now been a North American growth pattern for half a century, the past two decades have shown the most drastic shift in settlement patterns seeing "suburban populations increase at ten times the rate of the city centres they surround" (Friedman \& Kravitz, 2002, p. 73). Many North American cities, recognizing the pressures of population growth and housing shortages, are continuing to allow suburban developments and accommodating for necessary urban housing requirements in the form of high-rise/high-density developments. However, many theorists are suggesting that this type of reckless development is damaging not only to the environment but to our cities urban form and human psyche.
The arts of architecture and city planning could be evolved to provide sustainable and civilizing environments.

(Rogers, 1997, p. 4 ). 
Richard Rogers, in his book Cities For a Small Planet, refers to current sprawling cities as "parasites on the landscape" (Rogers, 1997, p. 27) calling for dramatic reconsiderations of planning policies in order to prevent sprawl and promote the sensitive re-densification of urban centres. Rogers' theories in his work echo those of The New Urbanists, who include architects, urban planners, and developers that believe housing requirements can be solved through "well-designed infill [that] can create vibrant and revitalized communities" (McConnell \& Wiley, 2010 , p. 2). New Urbanism can be defined as growing out of the realization that suburban living segregates people and has created undesirable neighbourhoods that are dependent on the automobile. Their principles call for "creating communities that are livable, walkable and sustainable while raising the quality of life" (New Urbanism). While it is agreed that the living conditions in the suburbs need to be addressed, more should be done to

Nowhere is the implementation of sustainability more potent and more beneficial than in the city.

(Rogers, 1997, p. 5 ). keep people in the city in the first place where walkable, and desirable neighbourhoods already exist and do not need to be forcefully created after the fact.

Rogers (1997) believes that the North American population contains an inherent fear of living in close proximity, challenging us to plan for and design more compact living and to "reconsider the advantages of living in each other's company" (p. 33). The recognition that people still believe that the quality of life in the suburbs with a 600 square foot backyard is, as environmental Lawyer David Donnelly says, worth the commute, is due to the fact that they do not know any better (Donnelly, 2010). Cities For A Small Planet is a testament to Rogers' belief that the arts of architecture and city planning have the power of providing sustainable solutions to our current urban growth challenges. 

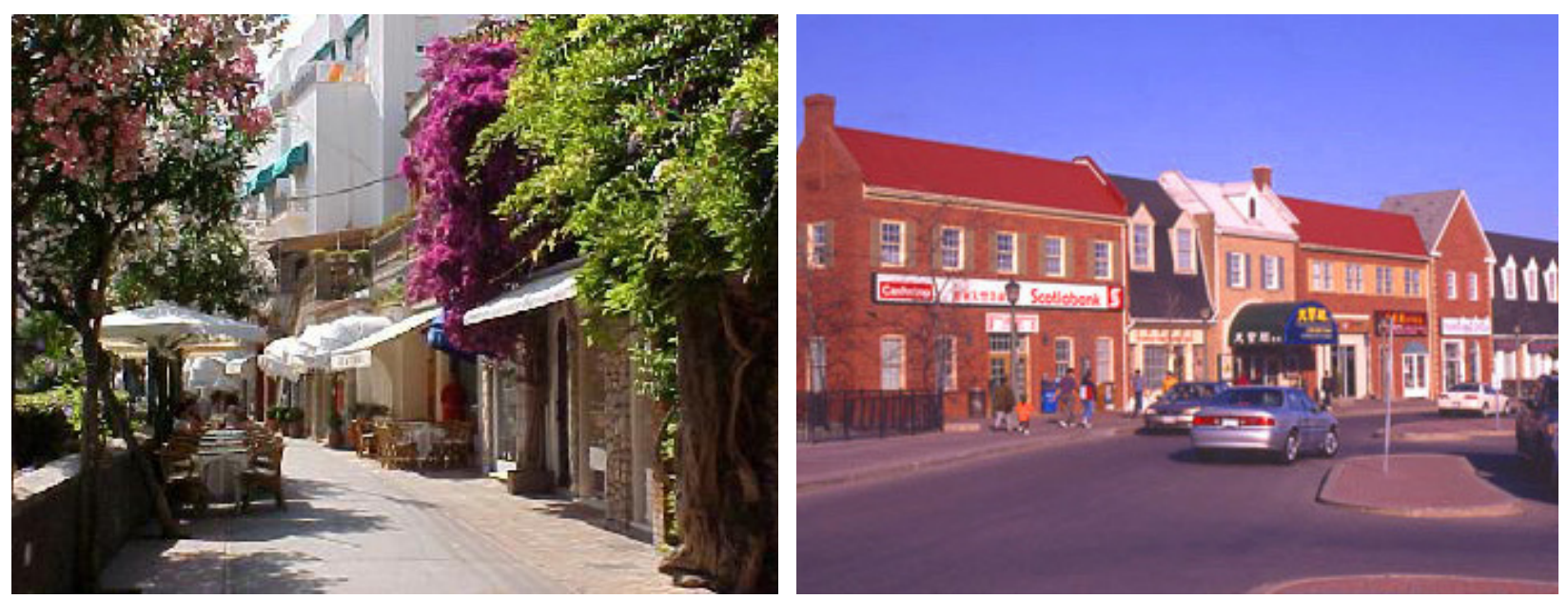

Figures 1-03, 1-04 The principles of New Urbanism attempt to promote desirable neighbourhood growth (such as the example newurbanism.org provides of a street in Capris, Italy) in existing suburban neighbourhoods. Toronto's suburban City of Markham's 'pedestrian friendly' street (image right) is an example of how New Urbanist principles are attempting to create a more aesthetic and usable condition to suburban developments.

\section{Opportunity in Existing Urban Form}

Vacant Lottery, is a term coined by Architects Barton Myers and George Baird used "to describe a philosophy of urban consolidation, an approach to urban development in opposition to...a uni-centered, high-density/high-rise North American city with its sprawling suburban periphery" (Myers \& Baird, 1978, p. 7). The strategy calls for looking for opportunities in existing urban form; finding unique solutions to increase density; and provide necessary housing without the need to destroy existing urban environments, instead finding underutilized pockets of urban fabric for development (Myers \& Baird, 1978, p. 7). This thesis echoes these beliefs, arguing that the under utilized infrastructure of laneways has the potential to provide housing in established desirable neighbourhoods that, with architecture as the tool, can convince people of the potential quality of life in these spaces.

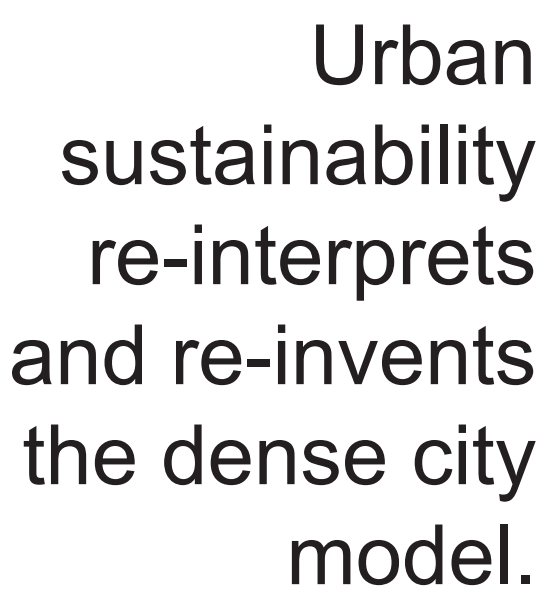

(Rogers, 1997, p. 32 ). 


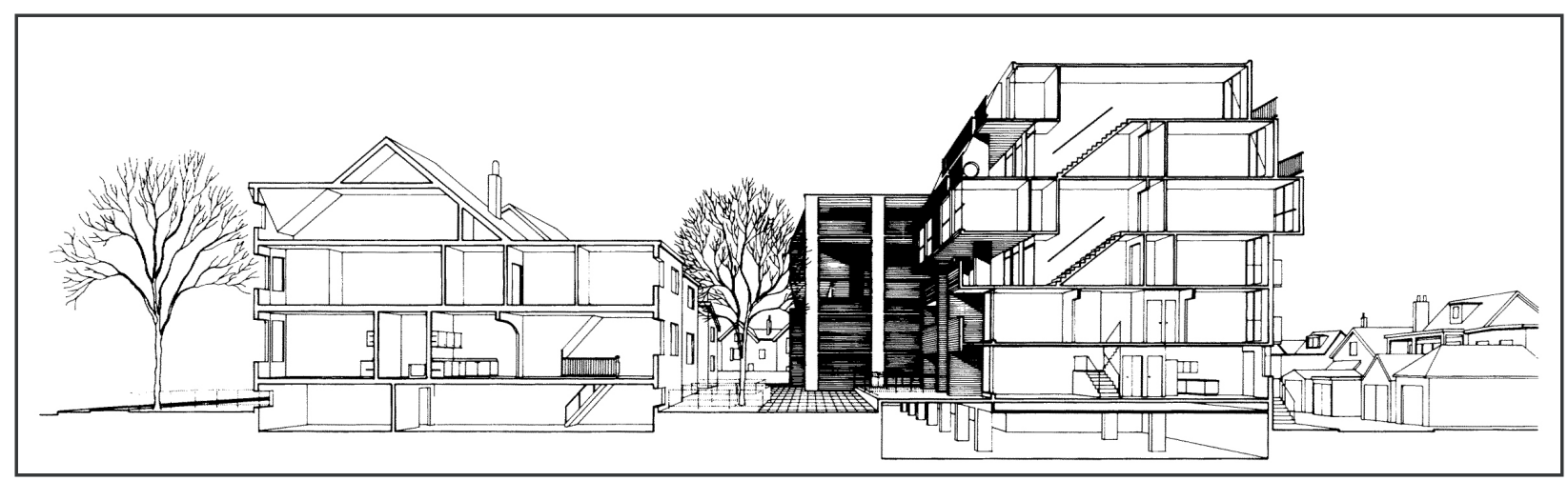

Figure 1-05 Sherbourne Lanes Section.

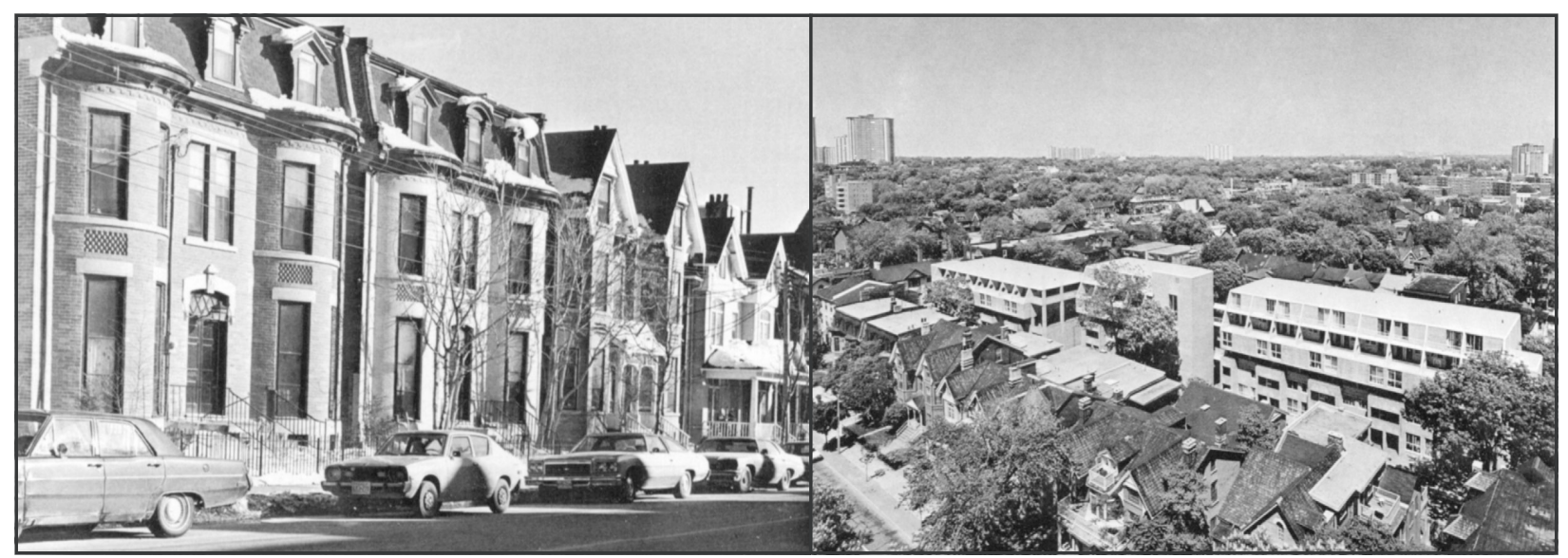

Figure 1-06, 1-07. The above images show how with careful consideration and unique architectural and planning interventions an increase in density is possible without the destruction of the existing character of established neighbourhoods.

Sherbourne Lanes, a Toronto infill project from 1976, is an example of how high-density infill can be achieved in a low-rise form without jeopardizing the existing character of a neighbourhood. The project, completed by Diamond and Myers, consisted of tucking a 6-storey apartment block behind a row of existing Victorian houses' deep lots. Part of a densification plan to provide affordable housing for the area, the architects managed to save the existing buildings, which were intended for destruction, by providing an infill design that achieved as many units as the originally proposed 28 storey towers. (Brytus, et al, 2001. p. 37). Their solution to fit the required number of units into an established neighbourhood on such as high-density scale is a precedent for laneway housing development which is feared due to the belief that this type of infill in established neighbourhoods will be destructive to their existing character. 
European cities have been setting precedents in using existing urban form to support housing requirements and sustainable initiatives for years. Many European cities have managed to maintain extensive density standards without compromising the necessity to increase building height allowances. They have accomplished this through employing unique ways of using existing urban form. One example of this is the Mews of London, England. Former stables, hidden on back alleys, these historical structures have been re-purposed for residential means. Hidden from the noise of main street congestion, London Mews, once simply an option to increase housing in the urban centre, have now become some of the most desirable residential neighbourhoods in the city.

Interest in the opportunities available in existing urban form in North American cities has been prevalent amoung urban planning theorists for decades now, constantly supported by the pressures of population growth and housing requirements. The City of New York has dealt with density by building vertically (specifically on the island of Manhattan) however, like London, England, New York's alleys, which used to house stables, have been converted into housing. Maintaining the historic essence of place, these residences in Greenwich Village are much desired addresses, offering a unique low rise, street related housing typology hard to find on the island.

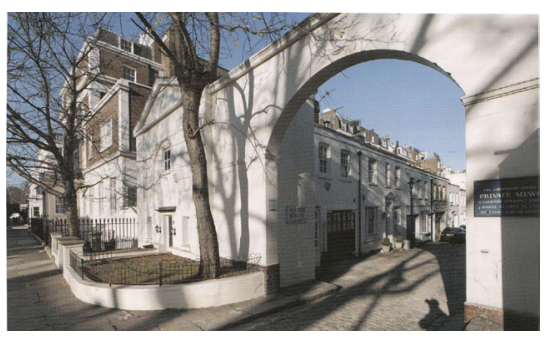

Figure 1-08 Entrance gate to Belgrave Place (private mews) in London, England.

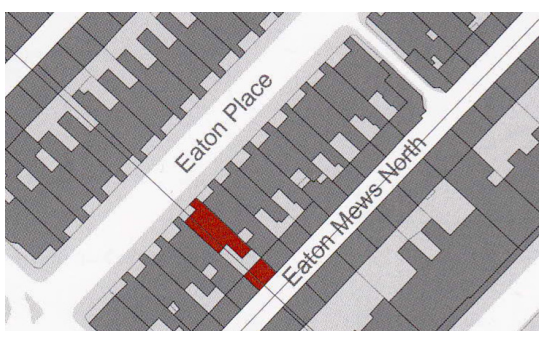

Figure 1-09 Site plan, showing London Mews, in context of the block typology and existing street fronting principal dwelling.

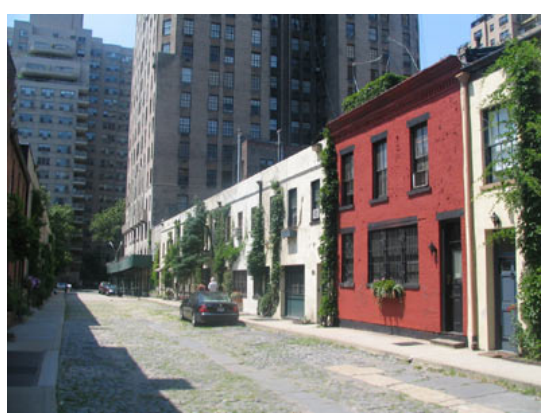

Figure 1-10 Washington Mews, Greenwich Village, NY. 


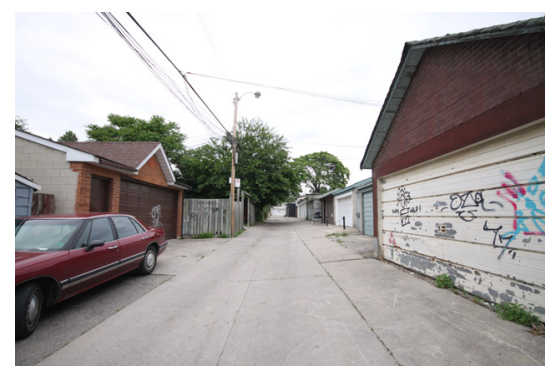

Figure 1-11 The typical North American residential laneway.

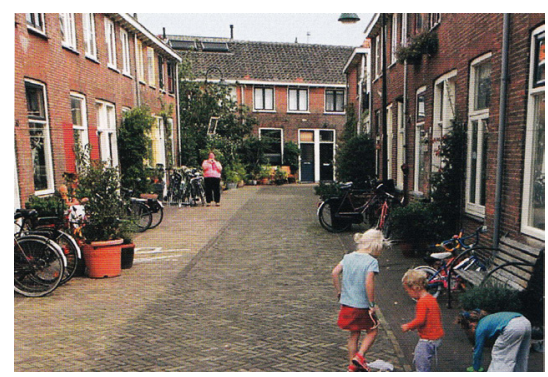

Figure 1-12 A European narrow street, where the users are given priority over the automobile.

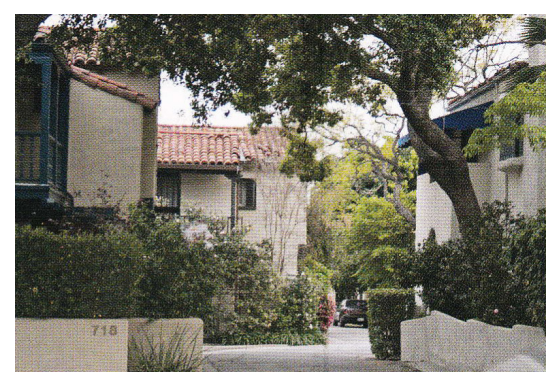

Figure 1-13 The entrance to a residential laneway in Pasadena, California.

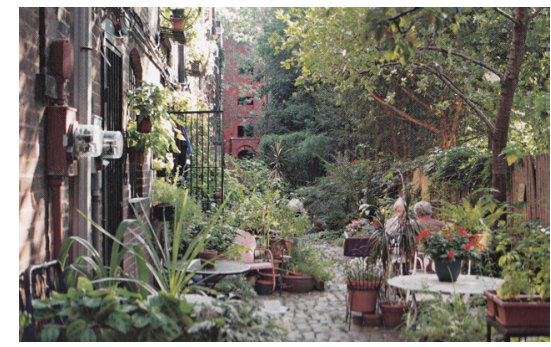

Figure 1-14 Warren Place, New York garden mews.
The recognition of alleys as extensive underused urban networks in the North American city occurred in the 1970s, in the midst of the environmental movement and boom of suburbia. The earliest and most thought out recognition of these spaces was completed by Grady Clay an American journalist. In 1979 Grady Clay was asked to examine the resource of alleys in Louisville, Kentucky. Once home to worker slums and stables Clay, in her book Alleys: A Hidden Resource (1979), recognized the potential of alleys for more than the storage of the automobile. Seeing them as an integral part of the larger urban system, Clay foresaw that rising energy prices and pressures on the environment would force a reconsideration of these places calling for policy reforms regarding land subdivision to allow the possibilities of housing development and the creation of communities in these spaces (Clay, 1979, p. 7).

\section{Out of sight, out of mind, the Ameri- can alley has been the academic, geo- graphic and social outcast of the built environment for at least a half-century.}

(Clay, 1979, p. 7)

The realization of the potentials for alley and laneway revitalization has been growing amoung numerous North American cities that contain this extensive infrastructure. Looking to precedents in Europe for ways to manage water runoff, increase pedestrian usability and reclaim the street from automobile dominance, the revitalization of alleys and laneways for greening programs and shared community spaces has been undertaken by Chicago, Seattle, Vancouver, Baltimore and Los Angeles with many other North American cities following suit. 

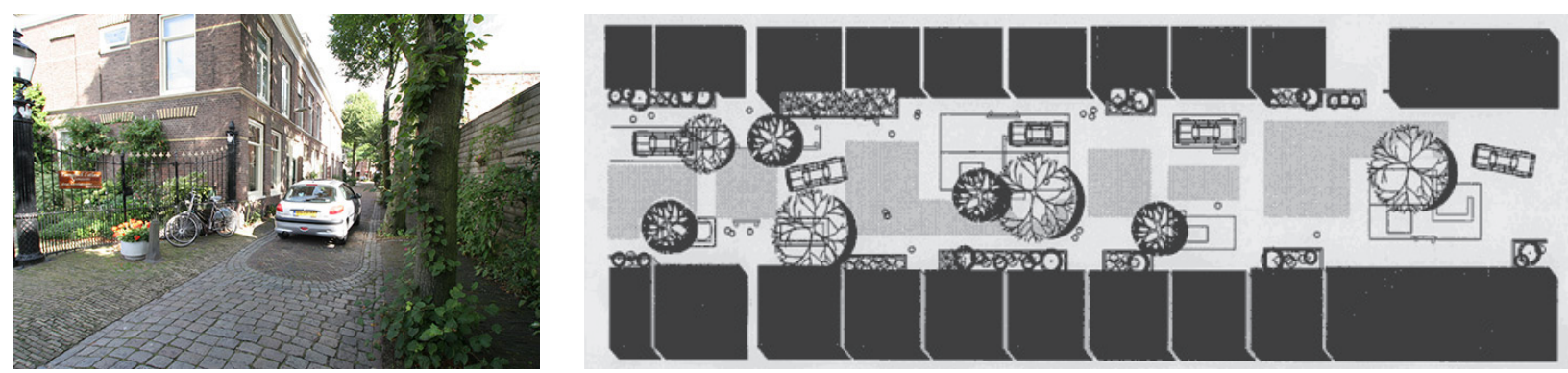

Figure 1-15, 1-16 Woonerf, literally meaning "living street," is a Dutch concept where pedestrians, bicyclists and casual loiterers have reign over the street, with paving, street furniture and planting forcefully controlling car usage and speeds (Chapin, 2011, p. 102). The woonerf concept has been adopted in North American cities that are attempting to reclaim the use of streets and lanes for community use.
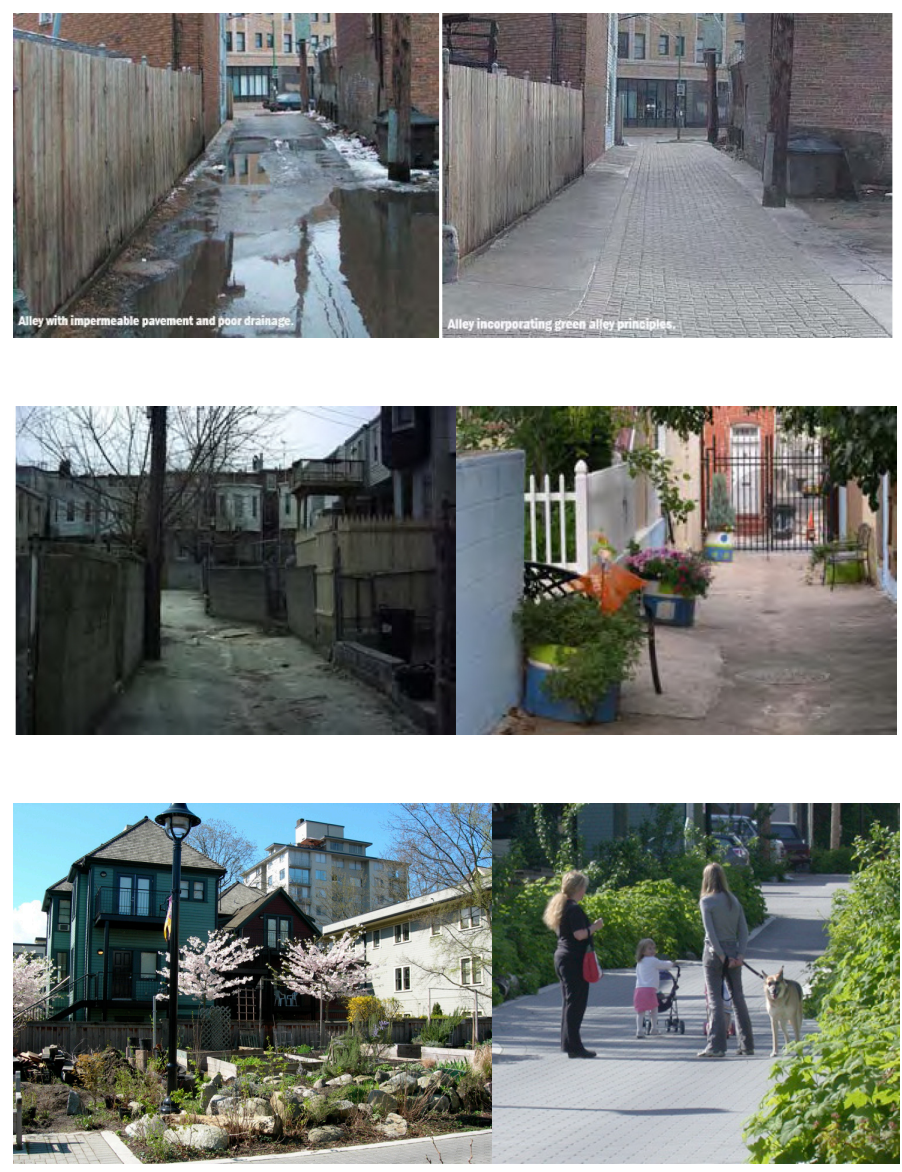

Figure 1-17 Chicago's Green Alleys Program recognizes the city's alley infrastructure as a place where sustainable management practices can be implemented. Permeable paving, dark sky lighting, and natural planting retention are being promoted throughout Chicago's alleys creating more favourable and usable spaces. (Attarian, 2010).

Figure 1-18 The City of Baltimore's Alley Gating and Greening Ordinance allows the city's residents to lease alleys and install gates as well as street furniture and implement gardening in order to "connect neighbors and strengthen social ties [and] create a vibrant, safe, and useful community space" (Cassidy et al, 2008, p. 21).

Figure 1-19 The City of Vancouver's preservation of the historical block of houses referred to as Mole Hill was completed in 2003. Part of the project, a laneway running in behind the existing houses, was envisioned as a shared community gathering place, encouraged through planting and community gardens.

\section{Think of streets as rooms...whose walls are made of build- ing faces, trees, hedges, and fences - rooms with a sense of enclosure that feel good to be in.}

(Chapin, 2011, p. 105) 


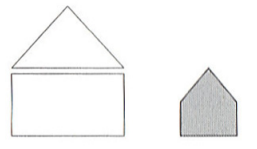

Constructing an ancillary unit

\begin{abstract}
unit to main house
\end{abstract}
Figure 1-20 Diagram of the ancillary dwelling in reference to the principal dwelling.

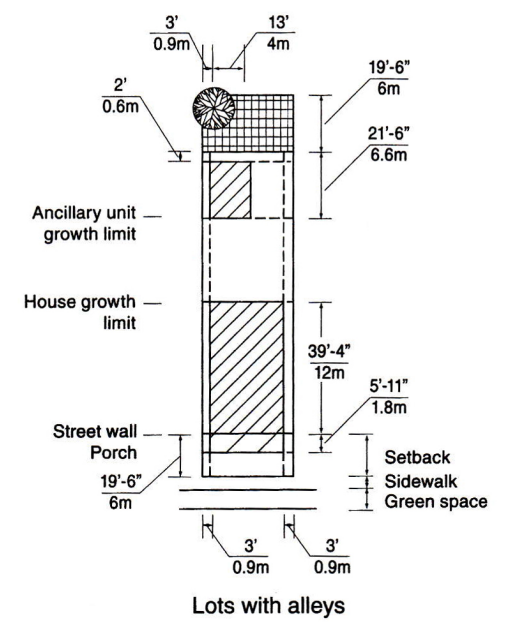

Figure 1-21 Avi Friedman's lot considerations in reference to ancillary dwelling design.

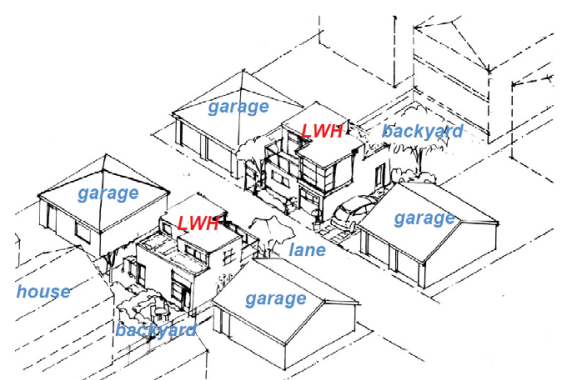

Figure 1-22 The City of Vancouver's Laneway Housing Illustrative Examples.

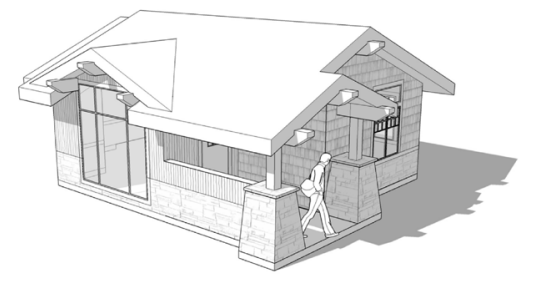

A GUIDE TO BUILDING A BACKYARD COTTAGE JUNE 2010

Figure 1-23 The City of Seattle's A Guide to Building a Backyard Cottage.

\section{The Changing Face of Housing Form}

Along with the growing recognition of the opportunities available in existing urban infrastructures such as laneways, there has been a parallel recognition of the move towards more unique forms of housing, based on societal changes. Peeking Through the Keyhole written by Architect and noted housing theorist Avi Friedman and colleague David Krawitz (2002), suggest that there is a large requirement for reconsidering our housing form, not only for the sake of protecting the environment, but also for the condition of the human psyche. Their theories argue that both suburban and high-rise/high-density living are isolated, out of context and absent of human scale (p.145), condemning current policies for continually supporting this type of development. Having dedicated his professional career to urban housing, Avi Friedman has written numerous books on the subject of changing housing form and its direct relationship to societal and environmental changes. All of Friedman's work has the underlying message that housing densification, in the form of ground related housing is necessary in achieving sustainable growth initiatives and providing the demanded type of housing in the demanded locations. Ancillary apartments have been suggested by Friedman as a solution to achieving the required housing form based on societal changes. Whether it be in the suburbs, or in existing inner city neighbourhoods, Friedman argues strongly for the potentials of ancillary dwelling units as an emerging and important future housing form.

While policy amendments to allow for urban centre residential densification strategies, such as accessory apartments and granny suites, have been prevalent in European countries for some time now, the push for these types of developments has only recently begun to occur in North American cities. 
The cities of Vancouver, British Columbia and Seattle, Washington have made a direct link between societal changes and the need for infill ground related housing in established neighbourhoods with the recognition of the sustainable and urban opportunities that existing laneway networks offer. In 2009 both cities amended their existing zoning policies to allow for laneway housing (backyard cottages in Seattle) development in their existing residential neighbourhoods.

This development has also proved to be extremely successful, attracting numerous user groups that want to live in established communities, in ground related housing. Young professionals, singles, and the aging, have been quick to recognize the opportunities that this building typology offers.
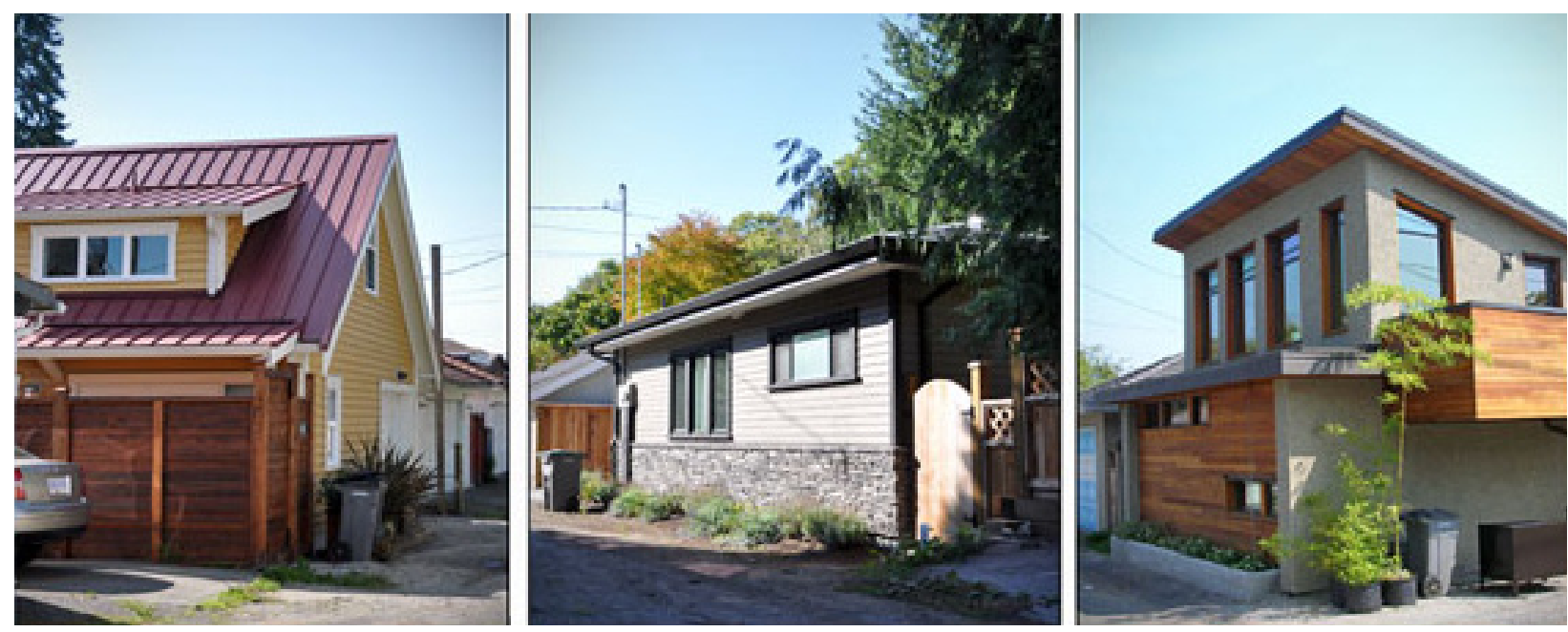

Figure 1-24 The City of Vancouver's laneway houses. Built behind existing dwellings, facing the lane. Vancouver approved laneway housing for rental tenure in 2009. Allowing the existing property owners to build laneway houses on their back lots has provided them with the opportunity to build an income property; a home to downsize into while renting out their existing property; or maintaining the presence of extended family members in close proximity. Restricted in size, to ensure market compatibility, these houses have also provided a much needed affordable rental typology for the City of Vancouver.

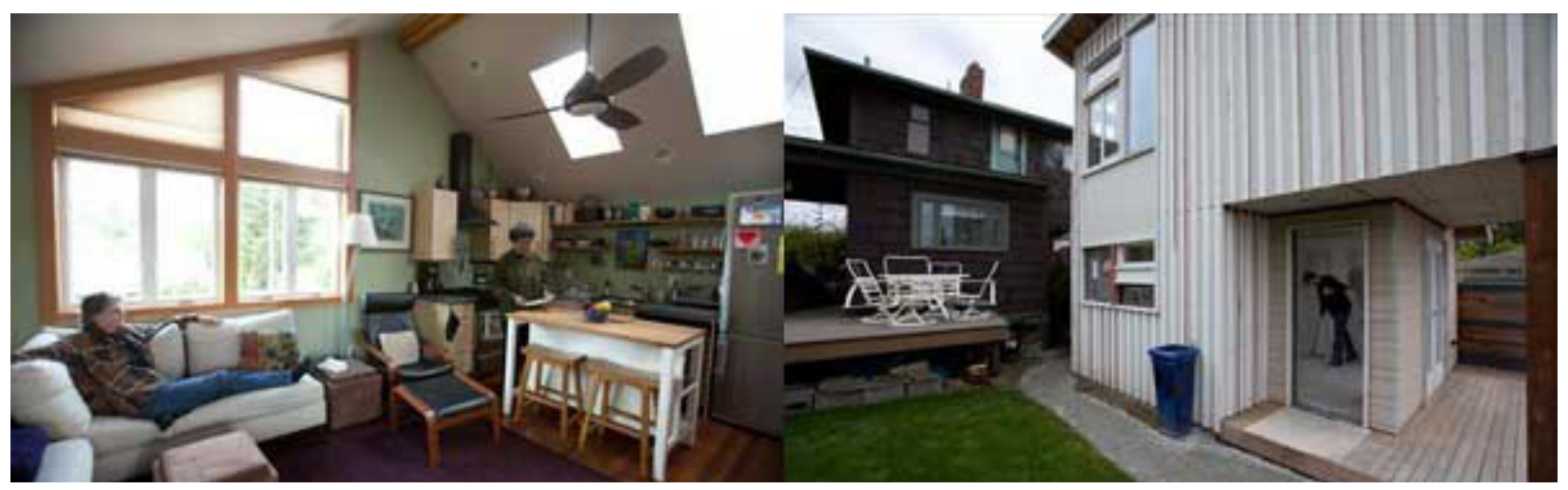

Figure 1-25 The City of Seattle's backyard cottages. Like Vancouver, Seattle's backyard cottages were approved for rental tenure city wide in 2009 , allowing existing property owners to maximize the return on their properties while contributing to the densification of the city. 


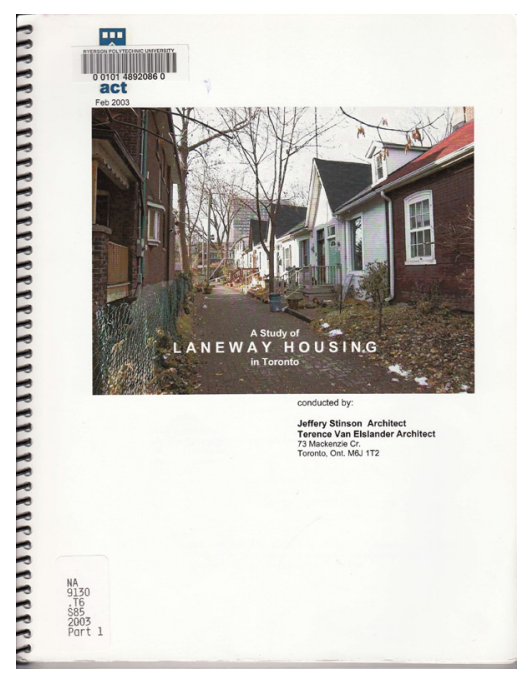

Figure 1-26 The typical North American residential laneway.

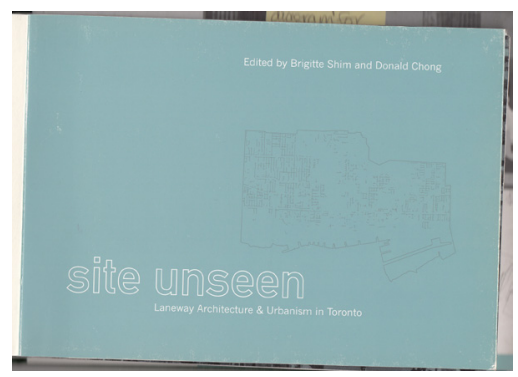

Figure 1-27 The typical North American residential laneway.
The City of Toronto is facing the same societal changes as many other North American cities. With issues of suburban sprawl, the need for sustainable development and an extensive existing laneway network, there have been several investigations conducted into the potential opportunities for laneway housing development in Toronto. While vernacular building forms exist in Toronto's laneways and a handful of progressive contemporary residential projects having been constructed, it was not until 2003, with A Study of Laneway Housing in Toronto (Stinson \& Van Elslander, 2003), that the potential for laneway housing on the city scale was investigated. This study, which argued that indeed the City of Toronto's urban form could support such development, gave way to subsequent works and inquiries on the subject.

In 2004 Architect Brigitte Shim, whose firm designed a Toronto laneway house in 1997 (see figure i-01), together with her colleague Donald Chong, led a studio on the subject of laneway housing at the University of Toronto's School of Architecture and Planning. Later published into a book Site Unseen: Laneway Architecture and Urbanism in Toronto (Shim \& Chong, 2004), this study, together with A Study of Laneway Housing in Toronto (Stinson \& Van Elslander, 2003) have become the most extensive, progressive and inspiring works on the potentials of laneway housing development in Toronto. 
Offering extensive analysis of Toronto's urban form and the evolution of the laneway infrastructure, both works also explore the development potentials in Toronto's laneways. Phase Two of $A$ Study of Laneway Housing in Toronto (Stinson \& Van Elslander, 2003) provides prototypical design suggestions for numerous laneway lot typologies, while Site Unseen: Laneway Architecture and Urbanism in Toronto (Shim \& Chong, 2004), offers imaginative student explorations for the different programmatically potentials of Toronto's laneway systems.

A Study of Laneway Housing in Toronto (Stinson \& Van Elslander, 2003), explores the relationship of the laneway house to the specific lot conditions, while the majority of the students work in Site Unseen: Laneway Architecture and Urbanism in Toronto (Shim \& Chong, 2004), observe the potentials of the laneway in its entirety, providing programmatic suggestions such as parks, student residences and markets. The combination of these two studies suggests the importance of understanding the relationship of the lanes built form to the lot and to the whole laneway on which it is constructed, and the envisioning of the potential evolution of these spaces into desirable pocket neighbourhoods. 


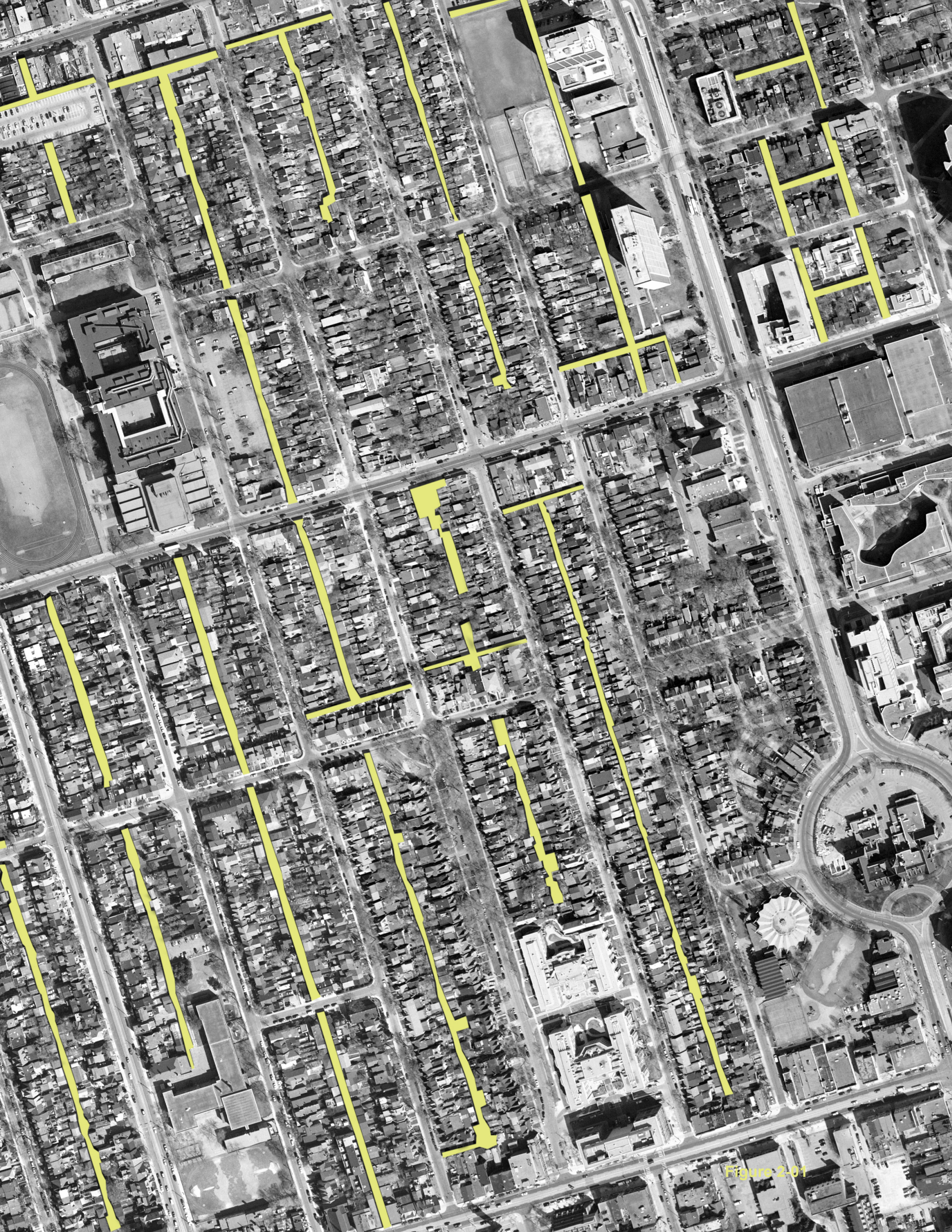




\section{An Argument for Laneway Housing in Toronto}

\section{Laneway and Laneway Housing History}

The word laneway is used to refer to a narrow street that runs either beside or behind buildings (SFS Planning, 2009, p. 7). The development of these laneways is a result of 19th century city planning. Toronto was originally settled along the waterfront and was organized into small square blocks, with large estates (park lots) granted to loyalist families running north-south between Queen Street (originally refereed to as Lot Street) and Bloor Street (Stinson \& Van Elslander, 2003). Throughout Toronto's history these estates were divided and sold off. Prior to subdivision control in the City, property owners were free to divide their properties as they wished (Vaughan, 2004, p. 2) resulting in varied forms of development throughout the City.

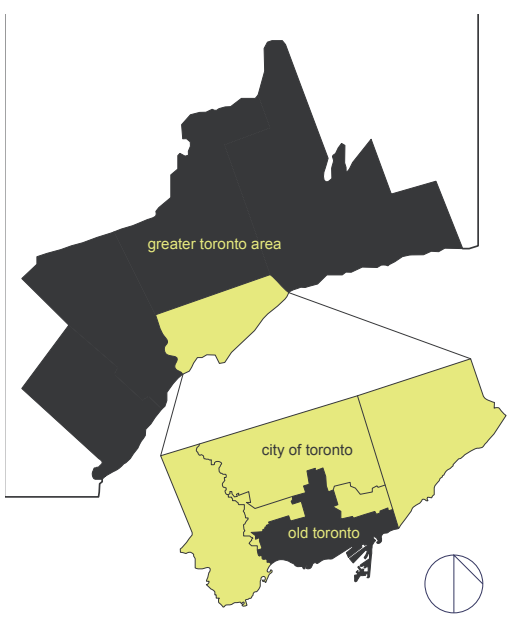

Figure 2-02 The Old City of Toronto in reference to the amalgamated City and Greater Toronto Area.
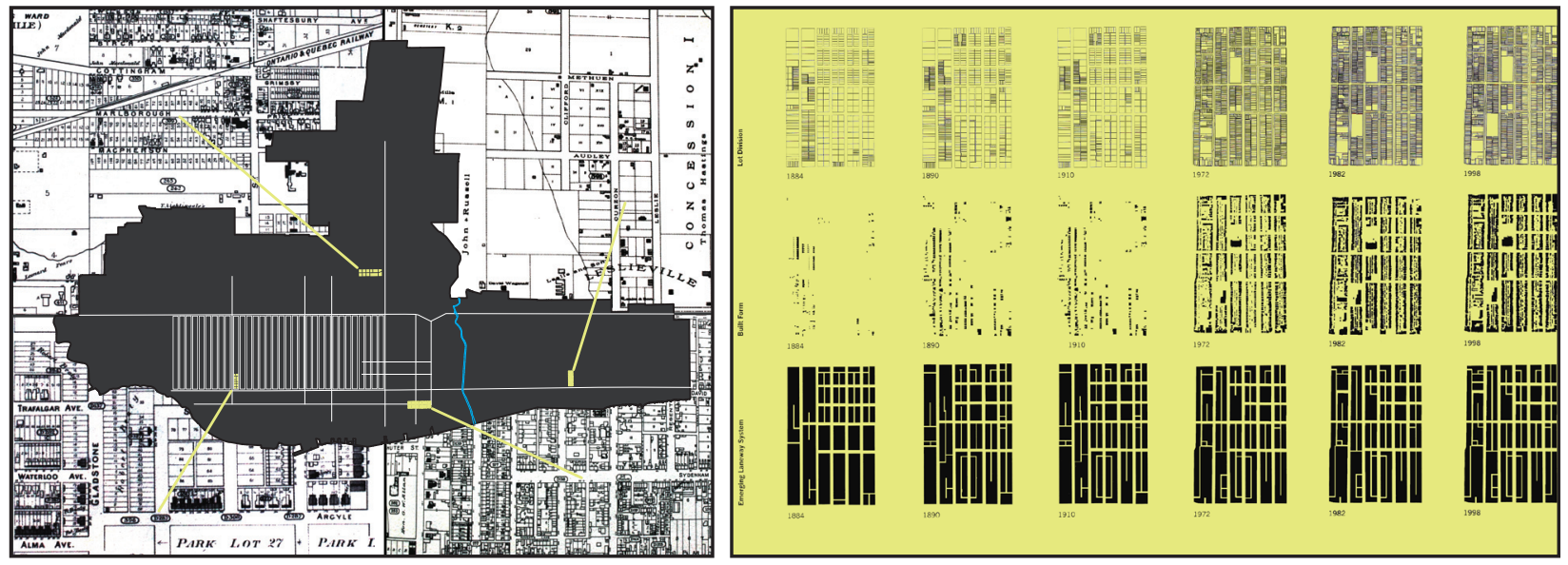

Figure 2-03, 2-04 (Left) Shows the City of Toronto's historical urban form development in reference to the park lots (shown in white). The division of land and building form density varied throughout the City. (Right) The emergence of the City of Toronto's laneway system in reference to lot division and built form.

Laneways became part of the urban fabric and were "instrumental in achieving density, the integration of services and uses and in maximizing land use" (Stinson \& Van Elslander, 2003). Most of Toronto's laneways were developed prior to automobile use and were used as pedestrian crossings or to aid in servicing residential and commercial buildings without causing main street congestion (Stinson \& Van Elslander, 2003). Laneways located in residential blocks provided access to carriage houses as well as housing for workers.

THIS IS (NOT) A LANEWAY. ENVISIONING TORONTO'S FUTURE MID-BLOCK COMMUNITIES. September 16, 2011. By: Maya Janikowski. Supervisor: Miljana Horvat. 


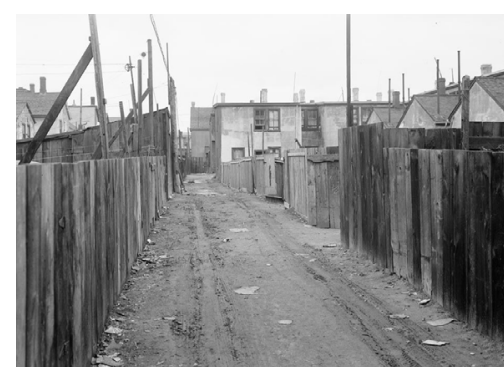

Figure 2-05

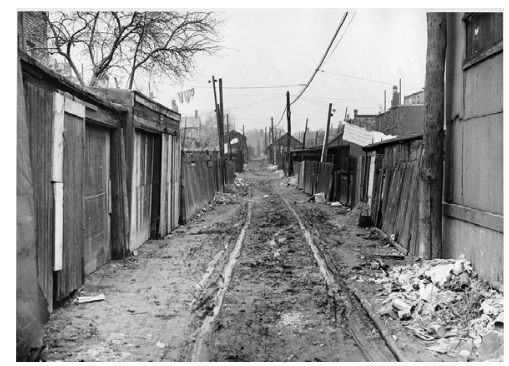

Figure 2-06

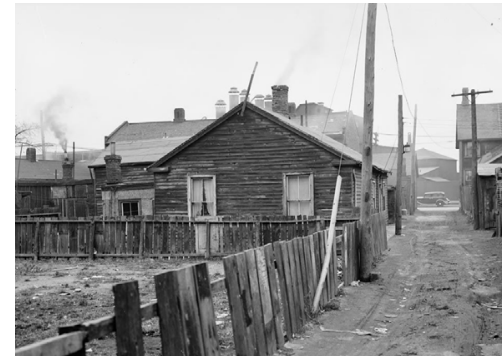

Figure 2-07

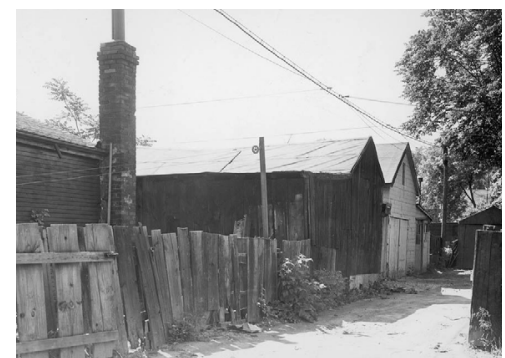

Figure 2-08

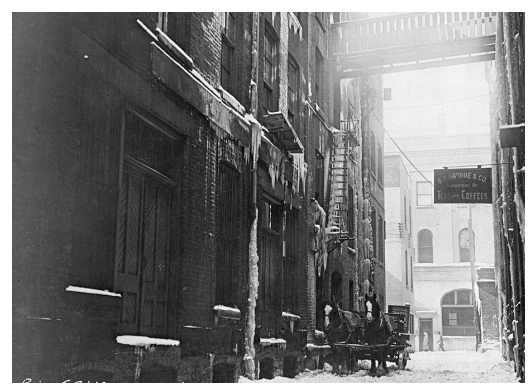

Laneway housing refers to "a detached form of infill housing that is ancillary to a principal dwelling and typically located in a rear yard and oriented towards the lane(way)" (Fisher, 2009, p. 1). The majority of these lots, where vernacular laneway buildings as well as some contemporary laneway houses are currently located, were formed prior to the implementation of zoning when there was no control over subdivision in Toronto and the owners of the lots could convey the use to what they wished (Vaughan, 2004, p.2).

Originally, these lots were severed to support numerous back alley industrial, commercial, storage purposes. Hundreds vernacular forms of this building type may still be found in Toronto. Some existing clustered housing on laneways emerged as turn of the century workers housing. Small plots of land were severed for the purpose of constructing temporary dwelling for the workers building the residential housing in new build turn of the century Toronto neighbourhoods. Many turned to disrepair and slums, giving these hidden housing types a bad reputation. Numerous barns, carriage and servant housing were also originally built in laneways and many have been well preserved and converted into residential, live work and studio spaces. These buildings are considered legal as they were constructed prior to the implementation of zoning as we know it.
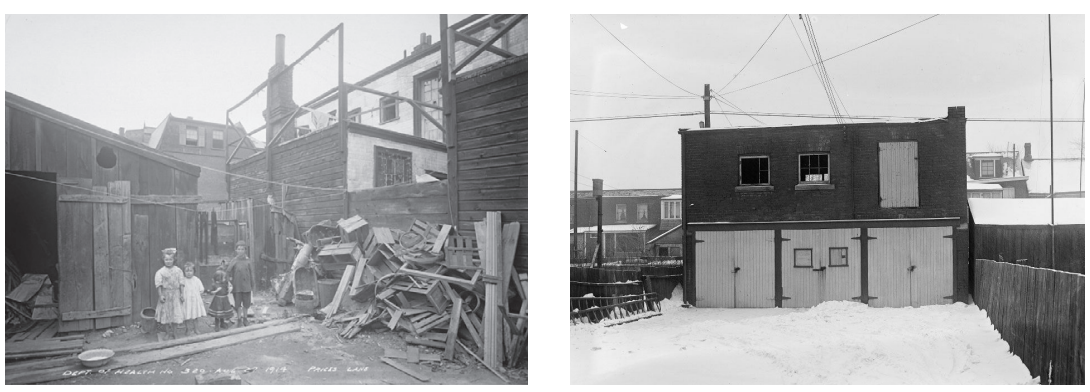

Figures 2-09 \& 2-10 Toronto's historical laneways. 


\section{The Current State of Toronto's Laneways}

Due to the nature of its historical development the City of Toronto contains a large number of laneways, with the largest concentration found within the Old or Pre-Amalgamated city. However, the majority of these laneways, especially those located within residential blocks, currently sit under used other than for the purpose of providing means to access parking garages. One of the reasons that the program of Toronto's laneways is so minimal is because of the way the municipal government views these spaces. The City of Toronto defines laneways solely as "facilities that are meant to provide vehicular access to properties, usually at the rear of lots" (Crowther, 2006, p. 7) seeing no other opportunity or purpose for this extensive network.

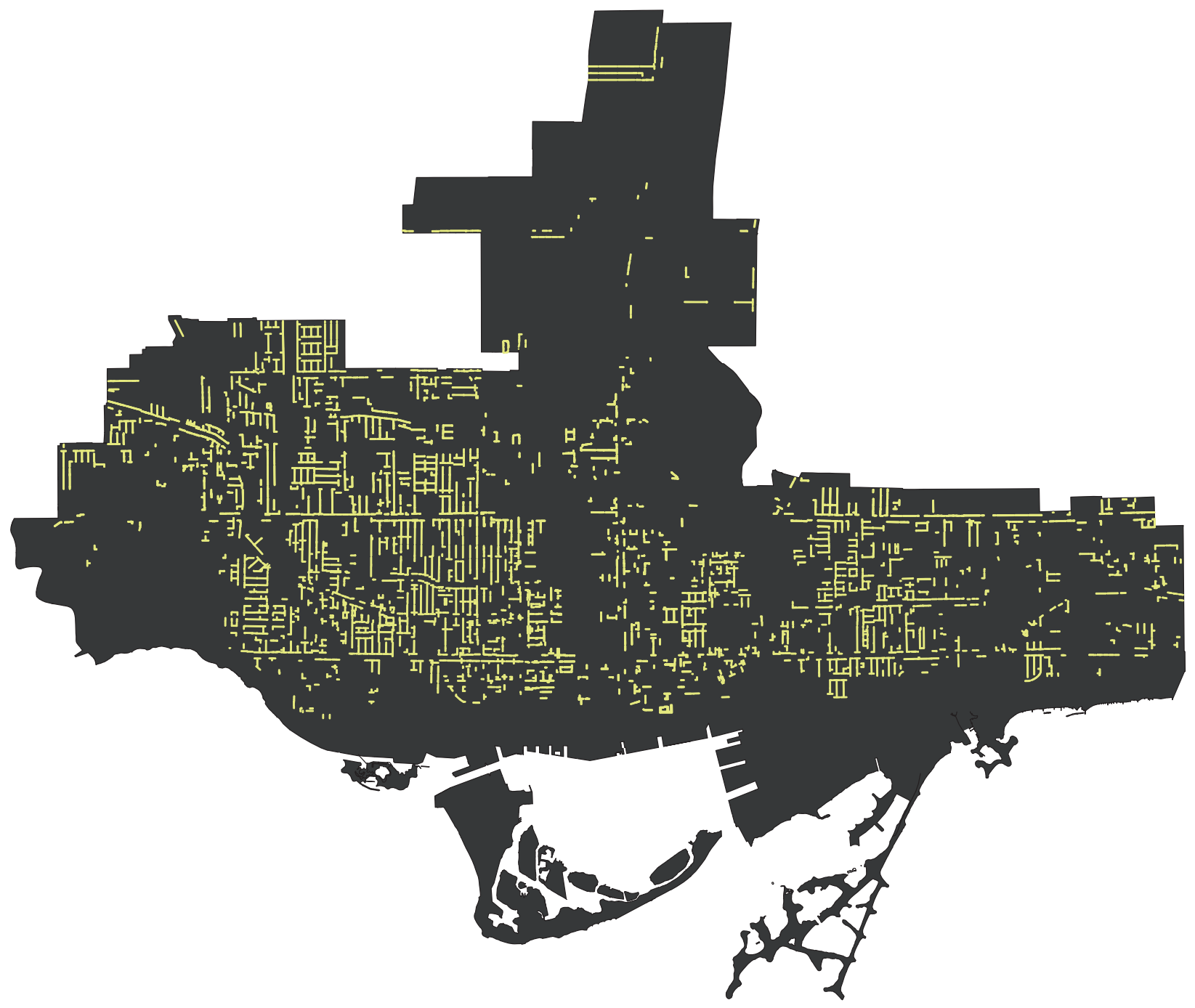

Figure 2-12 Laneway frequency in the Old (pre-amalgamated) City of Toronto. 


\begin{tabular}{|l|l|l|}
\hline Community \& council area & number of laneways & total length $(\mathrm{km})$ \\
\hline Toronto and East York & 1907 & 226.7 \\
\hline Etobicoke York & 359 & 56.5 \\
\hline North York & 109 & 19 \\
\hline Scarborough & 58 & 9.3 \\
\hline Total & 2433 & 311.5 \\
\hline
\end{tabular}

Table 2-01 Number and Length of City of Toronto public laneways by City Council Area.

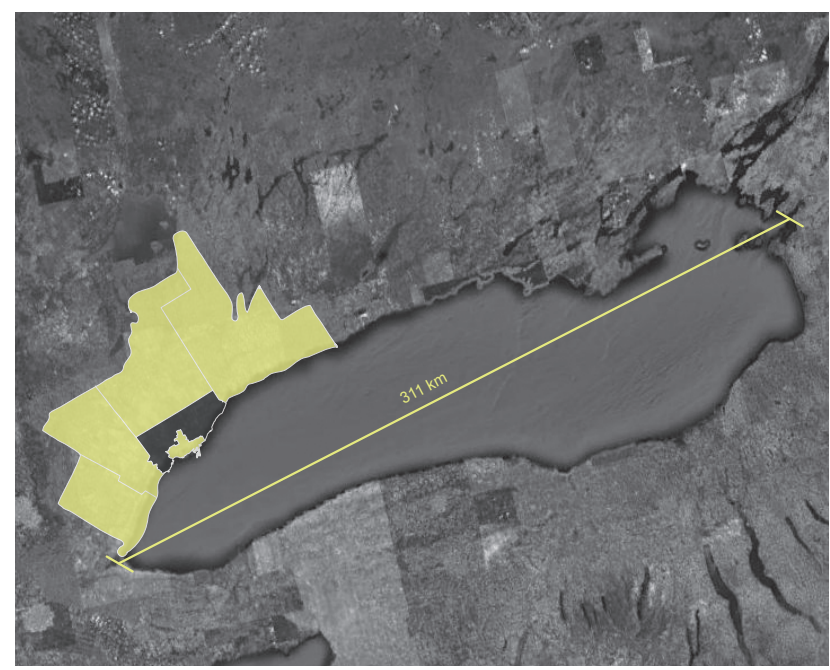

Figure 2-13 The City of Toronto's laneway system is equal to the length of Lake Ontario.
Misplaced in the political shuffle of the amalgamation of the City of Toronto, information and interest on the subject of laneways is almost non existent amoung the Municipality. It was not until recently when inquiries were being made into the repair and maintenance of this infrastructure, questioning the responsibility of the city, that the city requested a documentation of the exact extent of this infrastructure. The study identified 2,433 public laneways within the current city of Toronto, with the majority of them concentrated in the Old or Pre-amalgamated City, totalling over 300 kilometers in underused infrastructure. Only a fraction of these lanes are serviced with snow removal, garbage, mail and salting with service repairs occurring only by request.

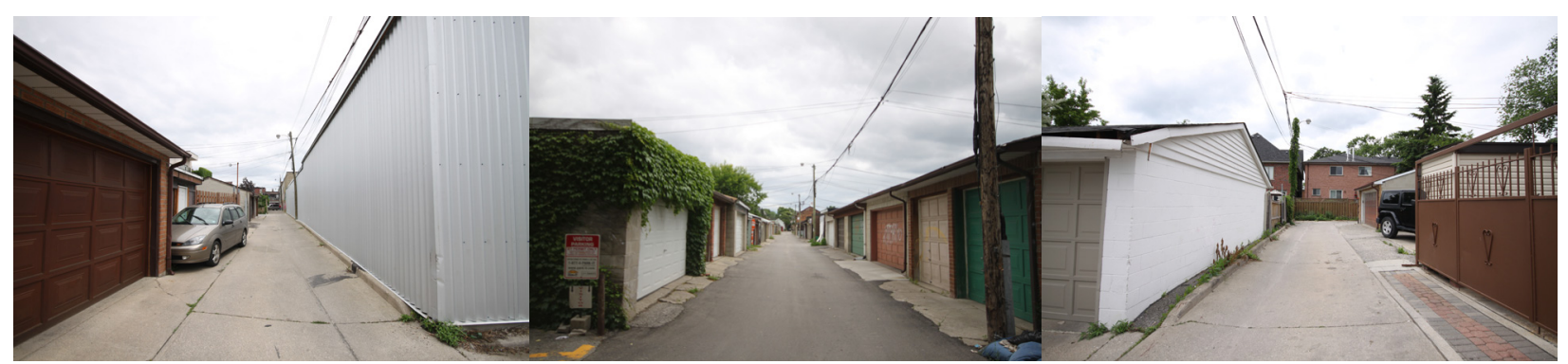

Figure 2-14 The current state of Toronto`s laneways. The majority of the city`s laneways sit under used. 


\section{Toronto's Laneway Typologies}

Emerging simultaneously with block division, the City of Toronto's laneway typologies and widths are varied, reflective of the neighbourhoods in which they exist and the original purposes they were intended to serve.
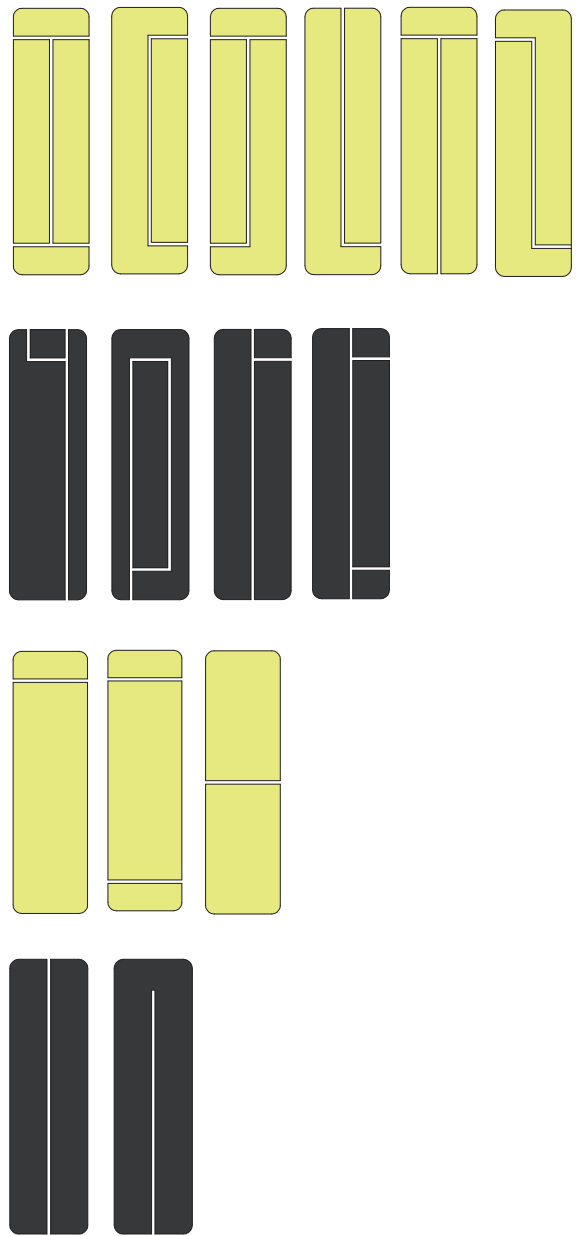

Figure 2-15
The alphabetical lane is a combination of short and long lanes. They are found in both strictly residential areas dividing commercial and residential lot typologies. Other than providing access to the long lane, the short lane commonly provides access to the backs of commercial properties. $43 \%$ frequency (Shim \& Chong, 2004, p. 29).

The miscellaneous lanes are most commonly attributed to unique block typologies (wide, extra long, irregular, etc). They can be found in residential, commercial or mixed neighbourhoods and provide access to rear commercial servicing and/or residential parking.

22\% frequency (Shim \& Chong, 2004, p. 29).

The short lane runs through the width of a block parallel to a main street separating commercial street fronting built form from residential built form. Most commonly used to service main street commercial building. They also create breaks in long residential blocks.

20\% frequency (Shim \& Chong, 2004, p. 28).

The long lane runs through the length of a block. More commonly found in residential areas, however this lane type could also run parallel to a main street separating commercial built form from residential built form. It provides access to commercial servicing as well as residential parking. $15 \%$ frequency (Shim \& Chong, 2004, p. 28).

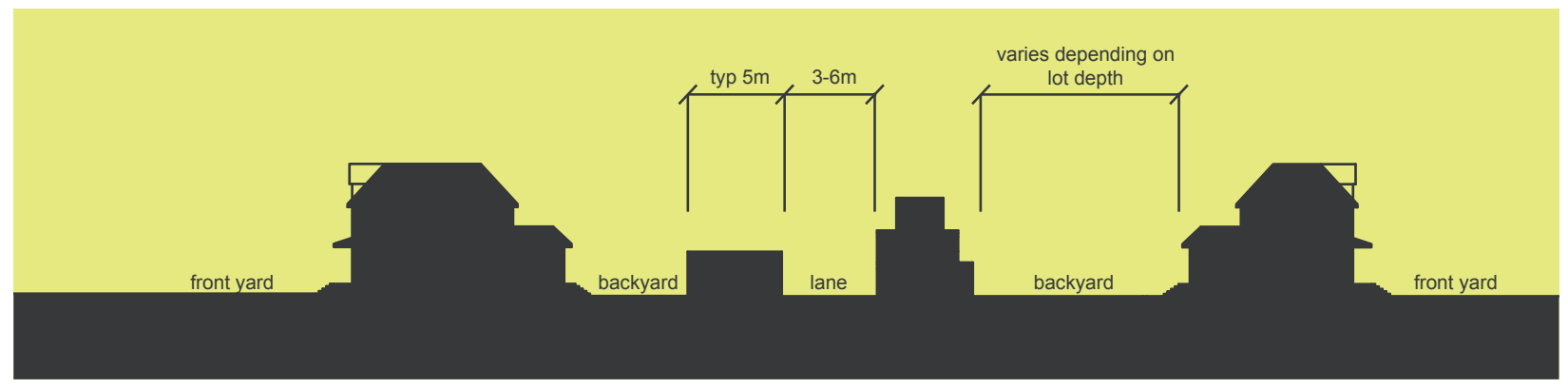

Figure 2-16 The typical Toronto residential block section containing a laneway, parking garages in the rear, and the occasional vernacular dwelling or laneway house. 


\section{Toronto's Laneway Housing Potential}

The current state of Toronto's laneways can be defined as one of abandonment and underuse. Not recognized as part of a larger system, their program is limited. However, A Study of Laneway Housing in Toronto (2003) conducted by architects Jeffrey Stinson and Terence Van Elslander discovered that the City of Toronto's laneways contain a significant potential for residential development. No longer viewed as an infrastructure void of purpose, this study has begun the discourse in the revitalization of laneways. The study concentrated on a portion of the Old City of Toronto. Based on strict criteria such as laneway lot sizes, densities, existing zoning regulations and the ability to sever land, the study discovered that laneway development could increase the number of dwellings in the Old (Pre-Amalgamated) City of Toronto by $5-10 \%$. According to this study, with 123,000 owned dwellings in pre-amalgamated Toronto $5 \%$ would amount to 6,150 ground level homes that could be added to Toronto's housing stock (Stinson \& Van Elslander, 2003).

By expanding the potential laneway housing boundaries to the whole City of Toronto which contains the laneway infrastructure the housing potential could be furthered. Using the same laneway lot resource parameters of $5-10 \%$ as The Study of Laneway Housing in Toronto (Stinson \& Van Elslander, 2003), with 532,490 owned dwellings in the City of Toronto (Statistics Canada), at $5 \%$ a potential of 26,625 homes could be added to the city.

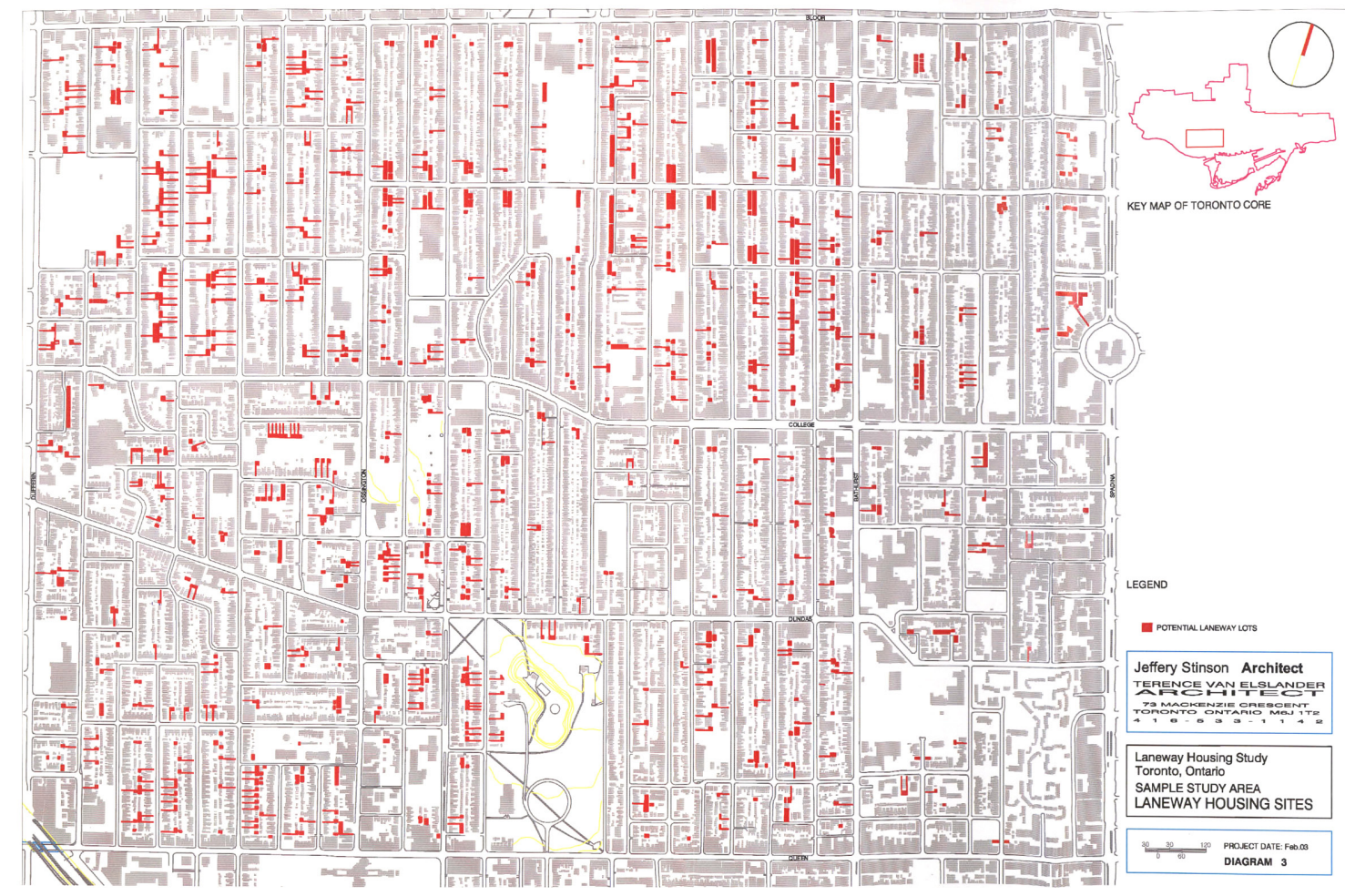

Figure 2-17 A Study of Laneway Housing in Toronto, Study Area Potential Laneway Housing Sites. 


\section{Toronto's Deepening Growth Challenges}

With an extensive laneway network that contains the potential to support housing development, The City of Toronto contains a significant opportunity in this hidden infrastructure. Making connections between available resources and growth challenges could be the key to the redefinition of laneway programing.

Barton Myers and George Baird, in their 1978 article titled Vacant Lottery, explain that "a lingering 19th century distrust of big cities; the poetic power of the 'garden city' concepts of Ebenezer Howards, reinterpreted by early modernists, Le Corbusier's 'towers in the park' concepts for inner core developments...and the extraordinary marketability of the single, detached suburban house (ranch) as the North American Dream" (Myers \& Baird, 1978, p. 11) are responsible for the current state of Toronto's urban form and development patterns. Favouring suburban sprawl and high-density/high-rise inner core developments for years, has resulted in the shortage of inner-city ground relating housing. This lack of this specific housing resource, has simply continued to perpetuate the negative and unsustainable development patterns, forcing those looking for ground related housing outside of the city, and those who favour city living into high-density/high rise options.
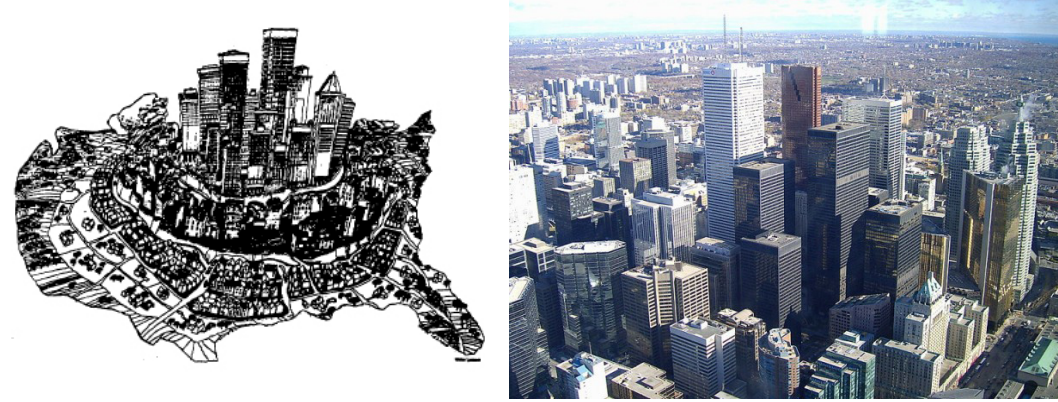

Figures 2-21, 2-22 (Left) Victor Lazzaro's 1978 vision of the USA as a uni-centered city. (Right) Contemporary City of Toronto resembles the qualities of the uni-centered city, with a high-rise/high-density inner city and sprawling peripheries.

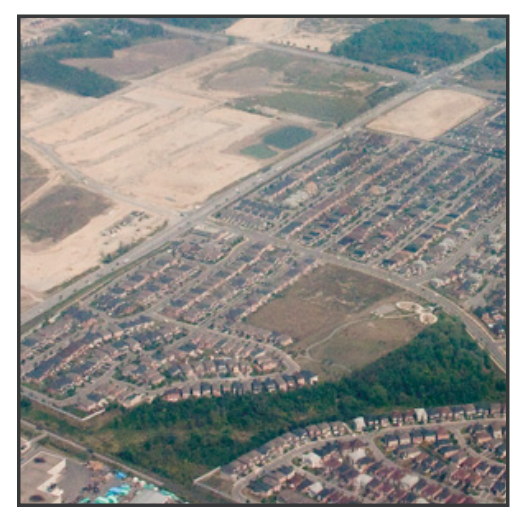

Figure 2-18 Toronto's suburban sprawl patterns are destroying greenfield land in order to provide a single family detached housing stock

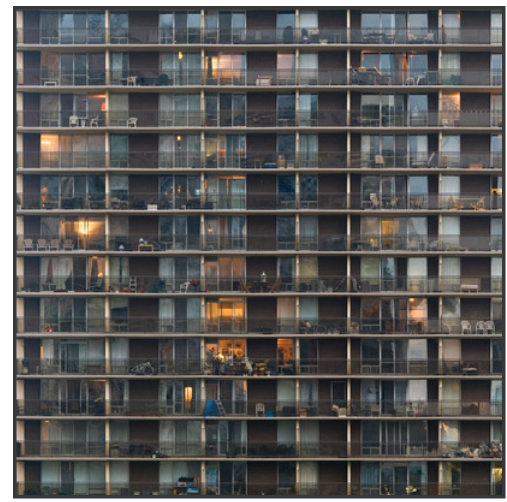

Figure 2-19 The City of Toronto is a city of apartments. Providing housing stock for those who want to stay in the city but cannot afford detached housing.

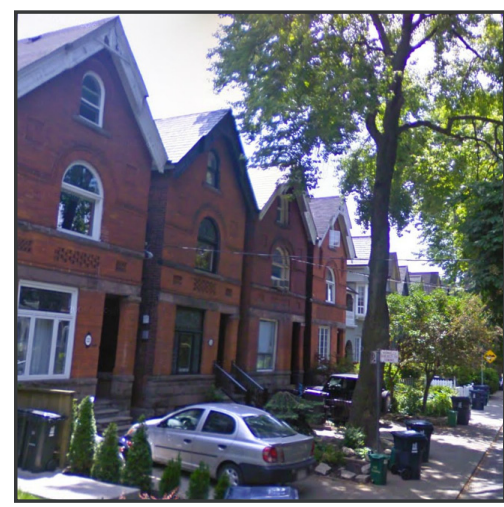

Figure 2-20 Toronto's limited ground related housing stock. Rising demand and prices are pushing people to periphery suburban developments in search of this housing typology. 
Toronto's population is projected to grow significantly in the next twenty years; however, most of this increase is forecasted to take place in the periphery regions of the Greater Toronto Area (GTA) and not in the City of Toronto (see figure 2-02). According to numerous studies on demographic patterns and housing tenure, the reason for settlement in the periphery of Toronto and not in the city itself is because, "the [City of] Toronto is now built out, and will accommodate housing growth [only] through intensification...many households looking for new housing, especially affordable ground related housing, have to look beyond the City" (Tyndorf, 2006, p. 5). This has caused a shift between the types of age groups living inside the City and those in the rest of the GTA. The majority of Toronto's young renters are concentrated in the city because $76 \%$ of the GTA's apartment units are in the City of Toronto. On the other hand, the majority of young people that are looking to own affordable ground related housing live outside of the city since $60 \%$ of these units are located in the rest of the GTA (Tyndorf, 2006, p. 10). This lack of ground related housing in the City of Toronto has caused a drastic shift in population distribution throughout Toronto over the last 30 years. Toronto's vulnerable population; such as young professionals, single parent families and the elderly, that depend on living in the city because of its available services and infrastructure, lack desirable and affordable housing options.

David Hulchansky in his study, The Three Cities Within Toronto. Income Polarization Among Toronto's Neighbourhoods, 1970-2005 (2010) explains that the city's highest income neighbourhoods are located within the central core or Old City of Toronto, while the lowest income households are located outside of the city in the periphery areas where there are inadequate services and infrastructures to support their daily needs. He suggests that "these growing trends could be slowed or reversed by public policies that would make housing more affordable to low-income households, by expanding access to transit and services to neighbourhoods where the need is greatest" (Hulchanski, 2010, p 1) or by bringing affordable housing into the City where transit and the necessary services already exist.

Toronto's ground related housing stock will most likely continue to be developed on Greenfield land beyond the in the periphery regions of the GTA and beyond where land is cheaper and where incentives seem to favour sprawl development. As a result, "unless households shift their preferences or elect to occupy the row housing, apartments and condominiums that do exist in greater amounts at that time, then they are likely to move out of the City in search of preferable housing" (Tyndorf, 2006, p. 17). 


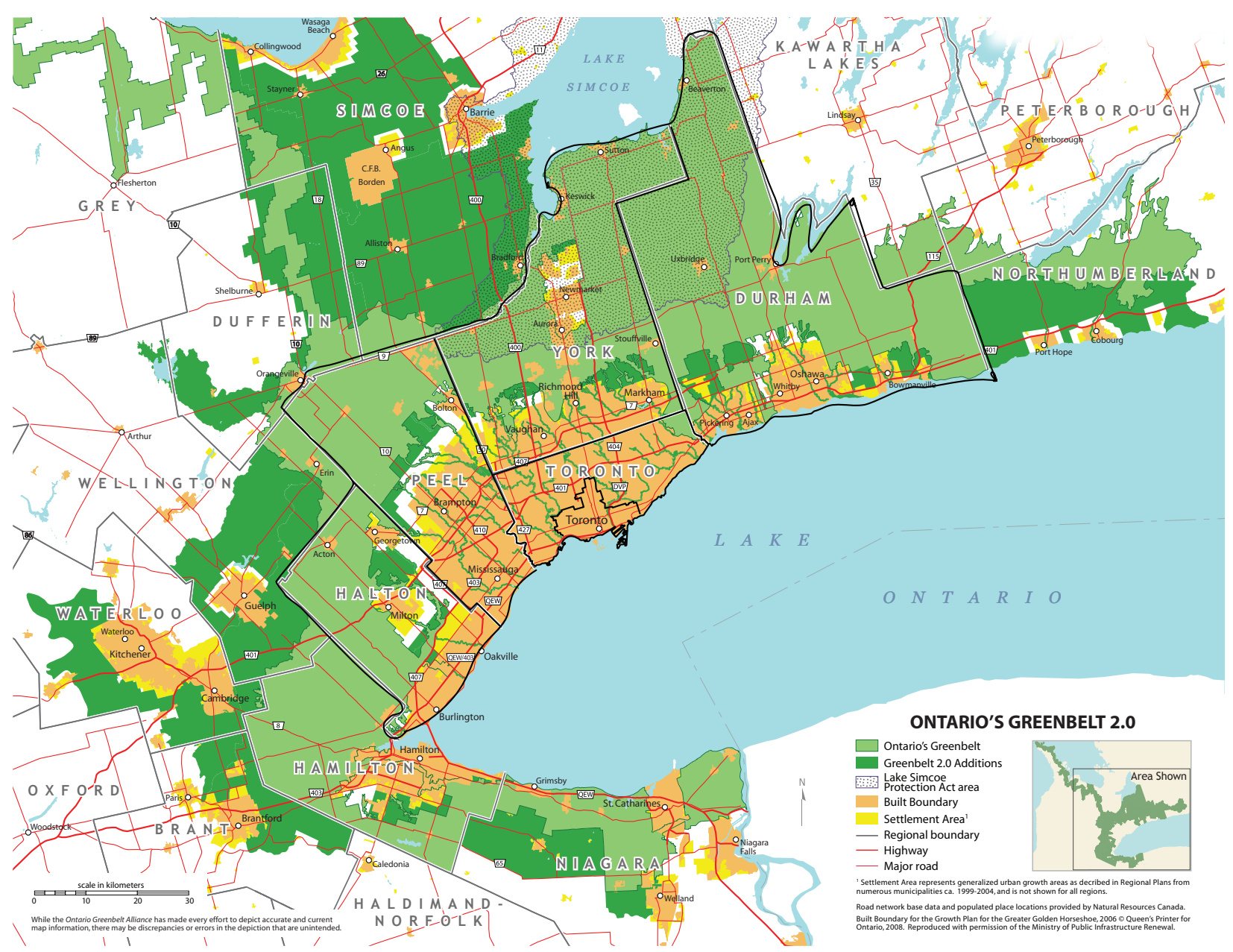

Figure 2-23 Toronto's built up area in reference to Ontario's protected greenbelt. The Old (pre-amalgamated) City of Toronto contains the largest concentration of Toronto's high-rise/high-density developments bordered by the city's old residential neighbourhoods. The new City of Toronto (post amalgamation) contains old-suburban lower density residential neighbourhoods, while the Greater Toronto Area contains continually growing auto-dependent new suburban developments that are infringing on protected greenfield land.
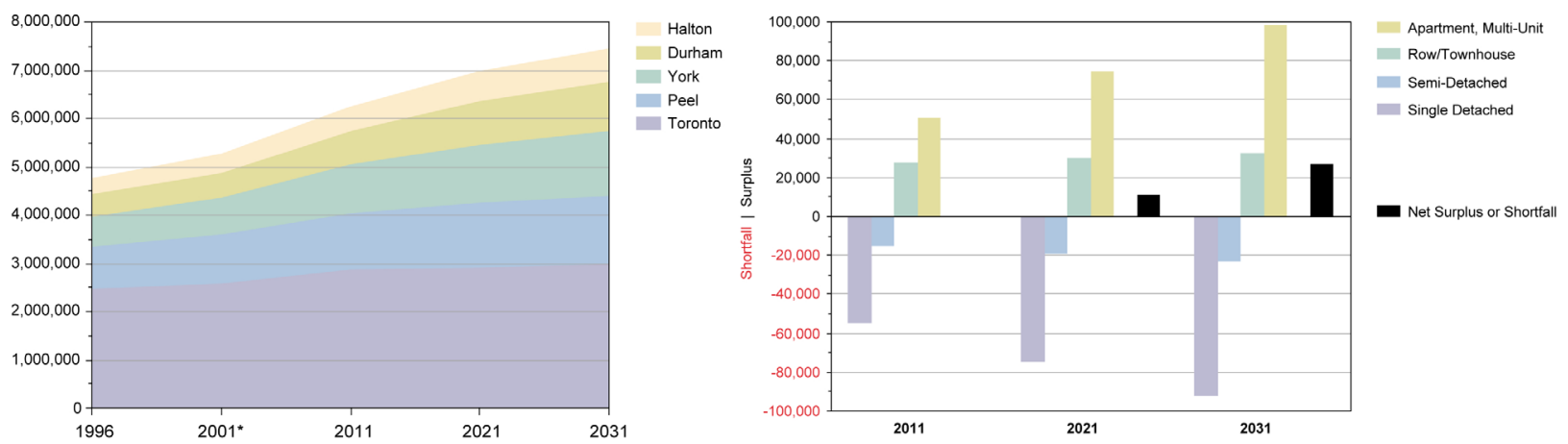

Table 2-02 (Left) Greater Toronto Area Forecasted Population showing the majority of growth will take place in low density suburban areas rather than in the City of Toronto. Table 2-03 (Right) The City of Toronto's Housing Surplus and Shortfall showing the current and projected shortage of single detailed ground related housing. 


\section{Sustainable Development Initiatives}

Recognizing the importance of planning for sustainable development to secure the requirements of the future population of Toronto, the city has adopted numerous initiatives to promote a smart growth plan for the Central Ontario region which includes the City of Toronto. Recommended by studies conducted by the Shape the Future Report (Central Ontario Smart Growth Panel, 2003) and Smart Development for Smart Growth report (Blais, 2003) the Toronto Official Plan (Tyndorf, T, 2009) recognizes the importance of density achieved through residential infill and intensification as an important housing initiative to curb sprawl development and promote smart growth. However, based on the directions of where to increase density dictated by the Toronto Official Plan, there still seems to be an inherent fear of the concept. According to the Plan, density in the form of reurbanization and infill will be directed in downtown mixed use and apartment neighbourhoods, suburban centers, and avenues and arterial corridors (Tyndorf, 2009). However, with the need for ground related housing in the City, these density directives seem to be avoiding densification where it is needed most; in existing established neighbourhoods.

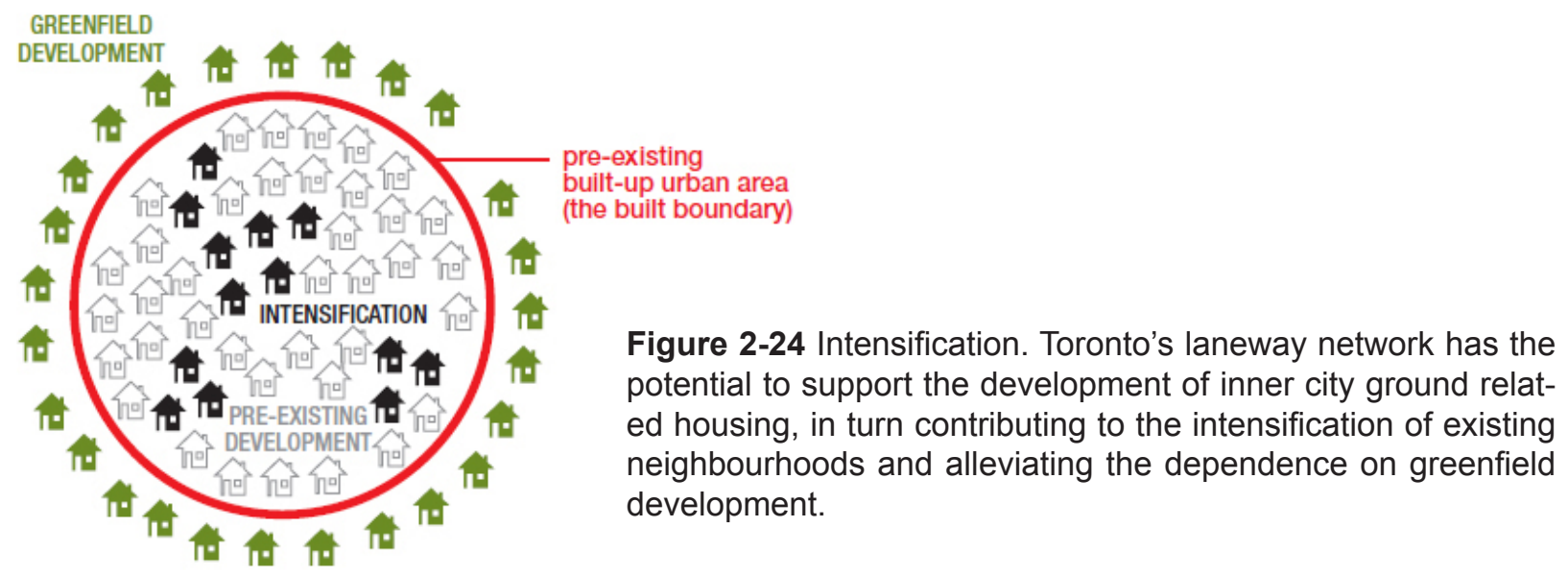

Laneway housing, as a form of infill, has the potential to encourage the densification of the City of Toronto with a ground related housing stock without jeopardizing the existing character of established residential neighbourhoods. 


\section{Laneway Housing's Role in Creating Great Neighbourhoods through Densification}

According to Creating Great Neighborhoods: Density in Your Community (US EPA, 2003) density creates great places to live by:

- creating walkable neighbourhoods;

- supports housing choice and affordability;

- helps expand transportation choices;

- supports community fiscal health;

- improves security and;

- protects the environment.

Laneway housing development contains all of the positive characteristics of considerate infill densification and in turn has the potential to help the city of Toronto allow for the continued growth of these neighbourhoods while building a foundation through which desirable micro neighbourhoods could be established on laneways.

\section{Creating Walkable Neighbourhoods}

The majority of Toronto's laneways are located within Old (pre-amalgamated) City of Toronto, which is home to the oldest and most established and vibrant residential neighbourhoods in the city. Located in pockets surrounded by commercial avenues, these residential neighbourhoods are within walking distance to all necessary amenities such as schools, parks, public transport, and places of work. Laneway housing infill would provide the necessary ground related housing in Toronto`s established and walkable communities.

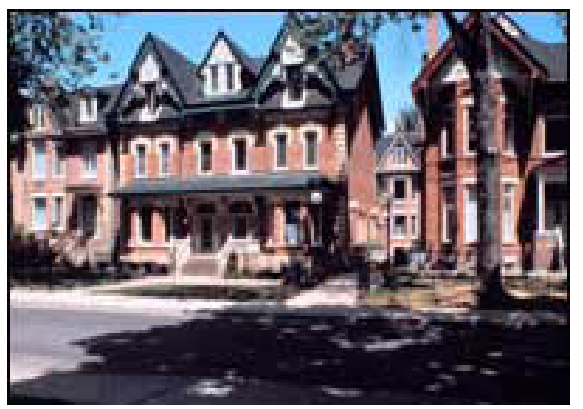

Figures 2-25 A established residential City of Toronto neighbourhood.

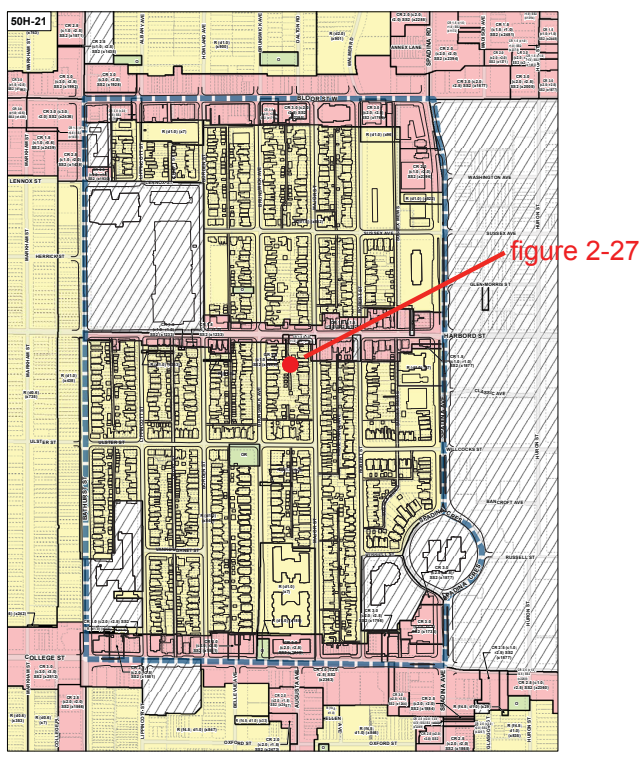

Figures 2-26 Map of a City of Toronto established residential neighbourhood (yellow) containing laneways in proximity to commercial/mixed use corridors (red).

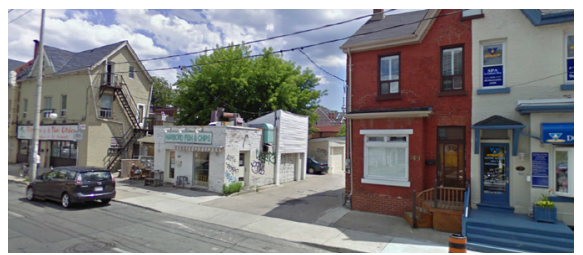

Figures 2-27 Laneway entrance off Harbord Street leading into residential neighbourhood. (see figure 2-26 for location). 


\begin{tabular}{|c|c|c|c|c|c|c|}
\hline & $\begin{array}{l}\text { Central area, mostly } \\
\text { high-llow-rise apts. } \\
\text { (e.g. Harbourtront) }\end{array}$ & $\begin{array}{l}\text { Cental area, mix of } \\
\text { housing } \\
\text { (e.g. Riverdale) }\end{array}$ & $\begin{array}{l}\text { Inner suburbs, mix } \\
\text { of housing } \\
\text { (e.g. Willowdale) }\end{array}$ & $\begin{array}{l}\text { Inner suburbs, } \\
\text { mostly detached } \\
\text { homes } \\
\text { (e.g. West Humber) }\end{array}$ & $\begin{array}{l}\text { Outer suburbs, mix } \\
\text { of housing } \\
\text { (e.g. Streetsville) }\end{array}$ & $\begin{array}{l}\text { Outer suburbs, } \\
\text { mostly detached } \\
\text { homes } \\
\text { (e.g. Vaughn) }\end{array}$ \\
\hline $\begin{array}{l}\text { Avg. no. of } \\
\text { schools within } 1 \\
\mathrm{~km}^{*}\end{array}$ & 11.9 & 13.5 & 7 & 5.5 & 3.6 & 3.2 \\
\hline $\begin{array}{l}\text { Avg. distance to } \\
\text { parks (m) }\end{array}$ & 300 & 290 & 330 & 380 & 640 & 660 \\
\hline $\begin{array}{l}\text { Jobs within } 1 \mathrm{~km} \\
\text { from home }\end{array}$ & 29,000 & 8,000 & 4,000 & 3,800 & 2,120 & 1,500 \\
\hline $\begin{array}{l}\text { Jobs within } 5 \mathrm{~km} \\
\text { from home }\end{array}$ & 328,000 & 290,000 & 116,000 & 86,000 & 48,000 & 37,000 \\
\hline $\begin{array}{l}\% \text { homes within } \\
1 \text { km of rapid } \\
\text { transit station }\end{array}$ & $67 \%$ & $45 \%$ & $12 \%$ & $7 \%$ & $0 \%$ & $0 \%$ \\
\hline
\end{tabular}

Table 2-04 Proximity to Daily Amenities. The Canadian Housing and Mortgage Corporation calculation of proximity to daily amenities based on the Toronto's residential areas.

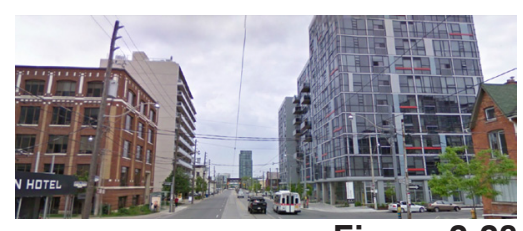

Figure 2-28

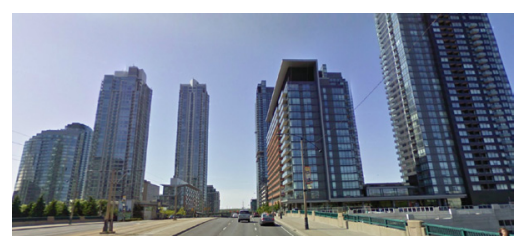

Figure 2-29

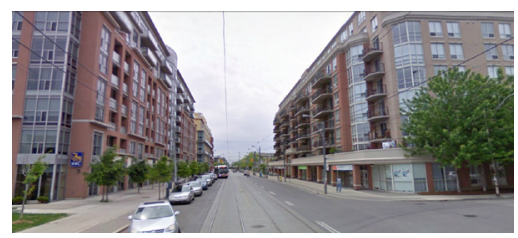

Figure 2-30

The City of Toronto's high-density/mid to high-rise residential developments constructed on the city's major avenues and commercial/mixed use corridors.

\section{Supporting Housing Choice and Affordability}

The City of Toronto's densification strategies along avenues and commercial corridors are producing a repetitive housing typology in high-density/mid to high-rise residential developments. Laneway housing, appealing to single people, working people, seniors and young families, has the opportunity to provide unique residential, even live work spaces, that can accommodate more diverse user groups than suburban and high-rise/ high-density developments, within Toronto's established neighbourhoods.

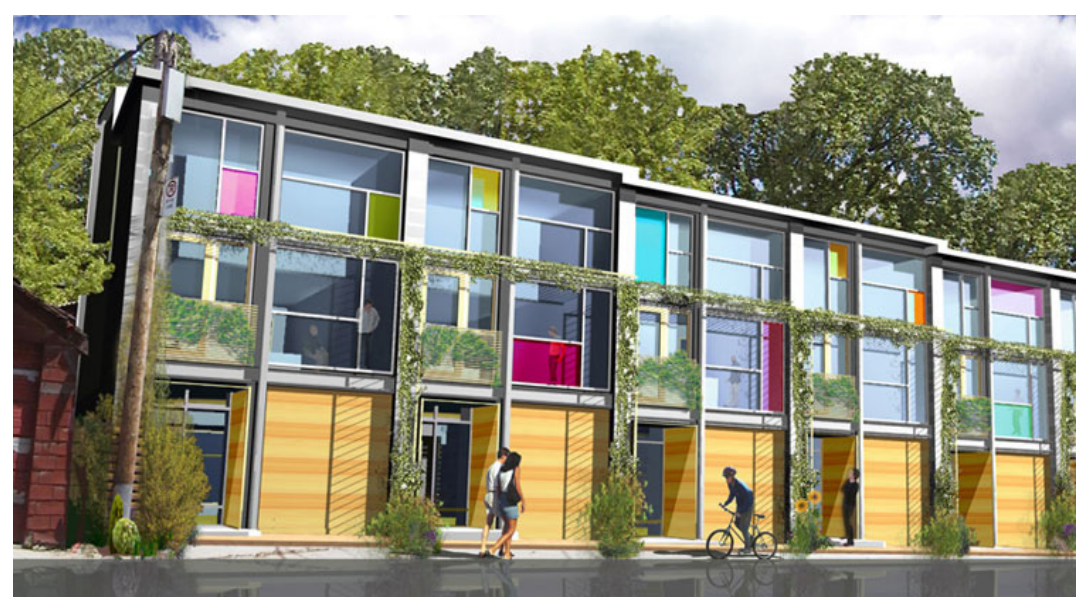

Figure 2-31 Proposed townhouse development by Van Elslander Carter Architects for a laneway in the City of Toronto. It is a great example of how low-rise residential infill can be incorporated into existing established neighbourhoods. 


\section{Helping Expand Transportation Choices}

Building in established neighbourhoods that are close to most necessary amenities alleviates reliance on the automobile. Increasing the amount of people living in these neighbourhoods, without accommodating the standard Toronto zoning requirement of one parking space per unit creates choice in alternative transportation methods such as bicycling, public transit and car share programs. More people looking for alternative choices will create demand thus financially supporting the development of necessary programs and increasing the usage of existing ones such as public transit (US EPA, 2003). A study conducted by the IBI Group on car share potentials found "that each car share vehicle typically allows three to four members to get rid of a vehicle they currently own, and helps approximately twice as many members to avoid purchasing a vehicle in the first place" (IBI Group, 2009, p. 21).

\section{Supporting Community Fiscal Health}

Increasing density in established neighbourhoods "can improve community fiscal health by reducing infrastructure duplication and making efficient use of present capacity, before investing in costly infrastructure expansion" (US EPA, 2003). The majority of Toronto's laneways contained all necessary infrastructure to support residential development. Effort should be placed in maintaining this extensive infrastructure system and updating those portions that do not contain appropriate servicing instead of constructing new infrastructure that supports unsustainable practices. Also, laneway development "property tax and developmental charges can increase the cities annual revenue by tens of millions of dollars"(Stinson \& Van Elslander, 2003) as well as provide fiscal contributions to local businesses, public transit use, and potential monetary value for property owners who decide to build laneway houses as income properties.

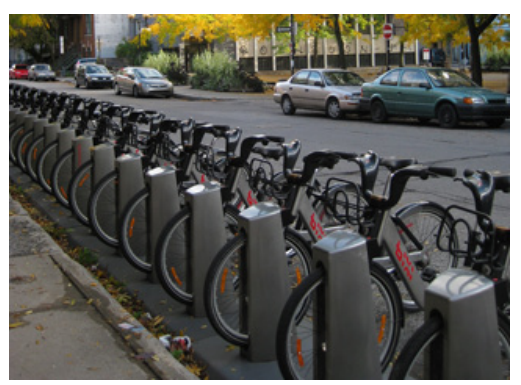

Figure 2-32 Toronto's BixiBike stations located throughout the city.

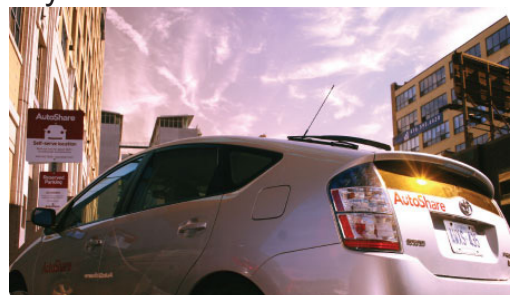

Figure 2-33 Toronto's AutoShare program has over one hundred locations throughout the city.

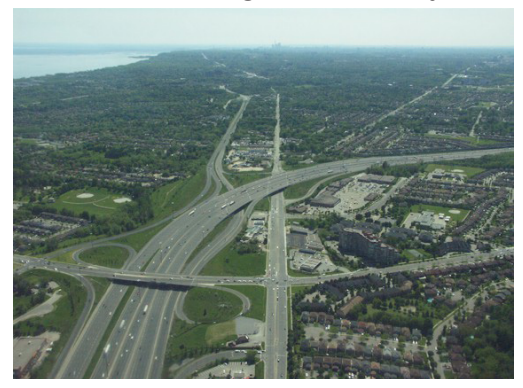

Figure 2-34 Construction of infrastructure, such as highways, that services auto-dependent residential communities cost the City of Toronto millions of dollars each year.

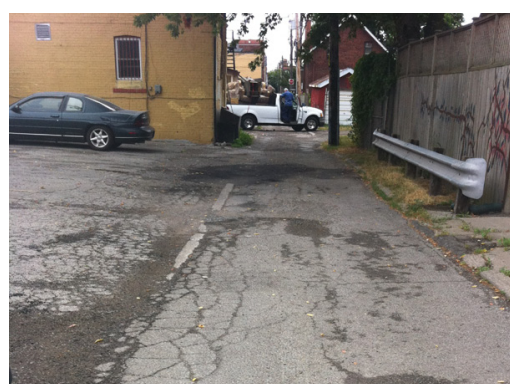

Figure 2-35 Existing infrastructure such a laneways receive little to no infrastructure updating. Yet, with investment, has the potential to support a large housing stock without the construction of new infrastructure. 


\section{Protecting The Environment}

Most important, out of all the densification characteristics that Laneway housing can help achieve, is its potential to help in protecting the environment. Infill projects around the world have been implemented for this very reason, with the realization that our growth patterns are destructive to the very environment that supports our needs. By building laneway housing in existing neighbourhoods there is an opportunity to concentrate people "within a smaller geographic area, reduce land consumption and allow communities to protect open space, habitat, farmland and ecologically sensitive areas" (US EPA, 2003). Based on the housing opportunity available in laneways established in The Study of Laneway Housing in Toronto (Stinson \& Van Elslander, 2003) coupled with the average Toronto household size of 2.8 pph (people per household) laneway development in Toronto could potentially prevent over sixteen thousand people from commuting in and out of the city each day. Or, looking at it from another perspective, laneway housing could protect thousands of hectares of greenfield land from development for ground related housing outside of the city.

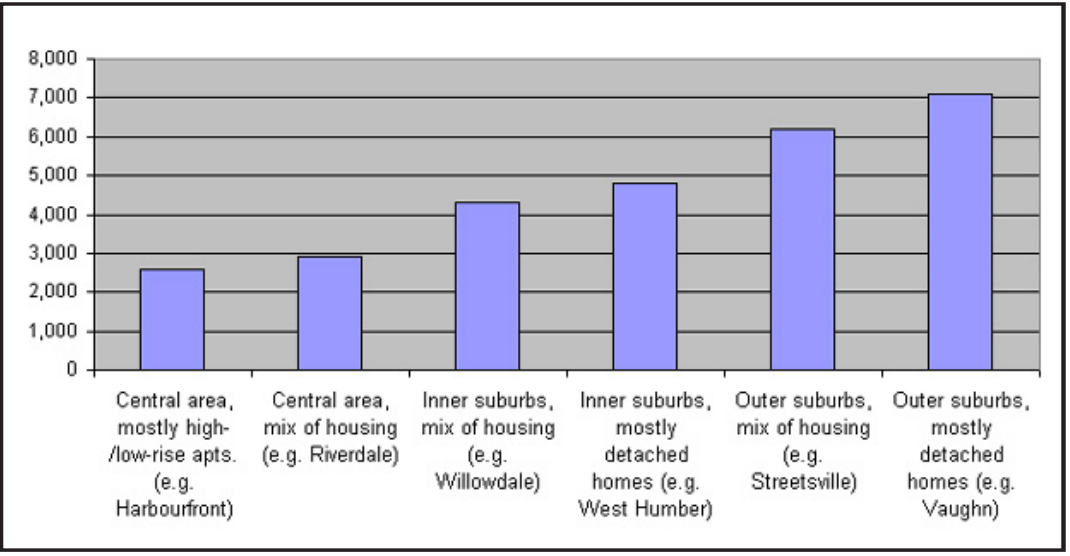

Table 2-05 Estimated annual greenhouse gas emission from weekday urban car trips - Toronto. Based on weekday urban travel, 245 weekdays, average GTA household size of 2.8 people. 


\section{Toronto Laneway Interest and Recognition}

Though the vast majority of Toronto's laneways maintain the appearance of urban wastelands a significant interest in these spaces and the specific laneway housing typology has been emerging in the city. For those of us to whom these places are unfamiliar territory, laneway walking or bicycling tours can be arranged by Graeme Parry, who has been exploring and mapping these hidden places for years. Stroll through Toronto's laneways and you may be surprised to find incredible vernacular architecture, hinting at a time when these lanes were recognized as part of Toronto urban system. Parry will also point you to contemporary artists studios and residences built by the few that recognize these lanes appeal.

The City of Toronto's press has also done a lot in increasing people's awareness and interest on the subject in recent years. Numerous newspapers, blogs and urban magazines have been reporting on the intrigue and housing opportunity in Toronto's laneways. Their subtle existence in Toronto's urban form causes excited attention to any unique laneway happenings. Even the City of Toronto itself has awarded recognition to urban initiatives in laneways.

Most interesting, is the fact that Toronto's own residents have shown an interest in making these laneways home. A survey was conducted for the purpose of this thesis two years ago, asking people whether they could see themselves living in a laneway, and the majority response was yes.

The existing infrastructure of laneways, coupled with the growing interest, are suggesting that a day may come in the near future where these places are respected and recognized in the potential they embody as desired residential communities. tour 1

Trinity Bellwoods, Little Italy,

Kensington Market and Queen West
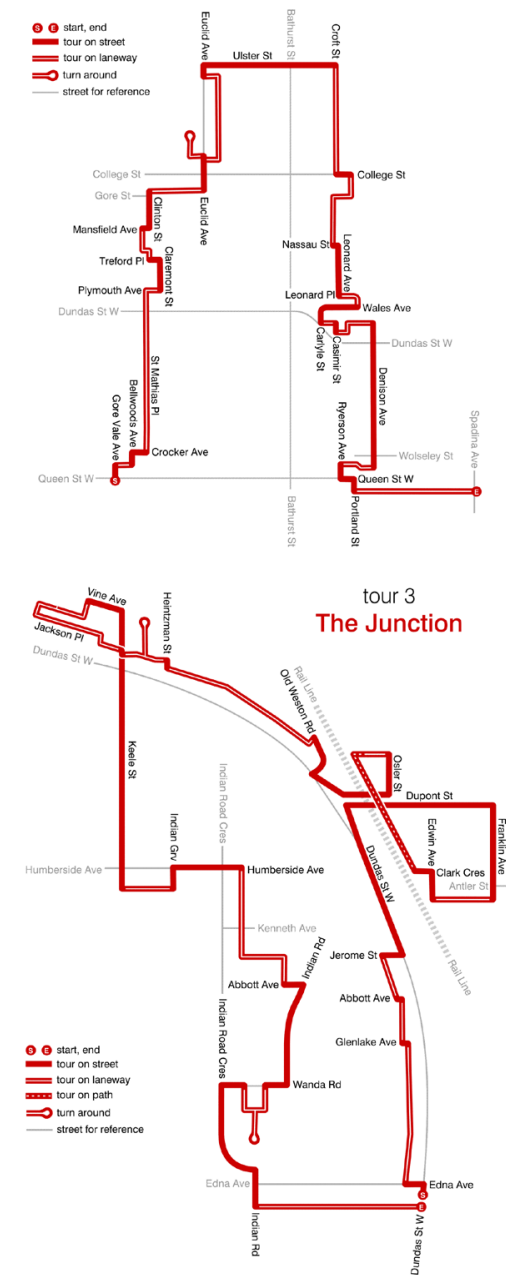

Figure 2-36 Graeme Perry's Toronto Alley way love affair tour maps.

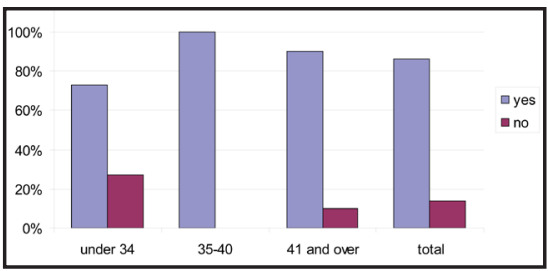

Table 2-06 Toronto Laneway Field Research survey indicates the interest in laneway housing as a option for numerous user groups looking for a unique residential opportunities located in the central areas of the City of Toronto. 


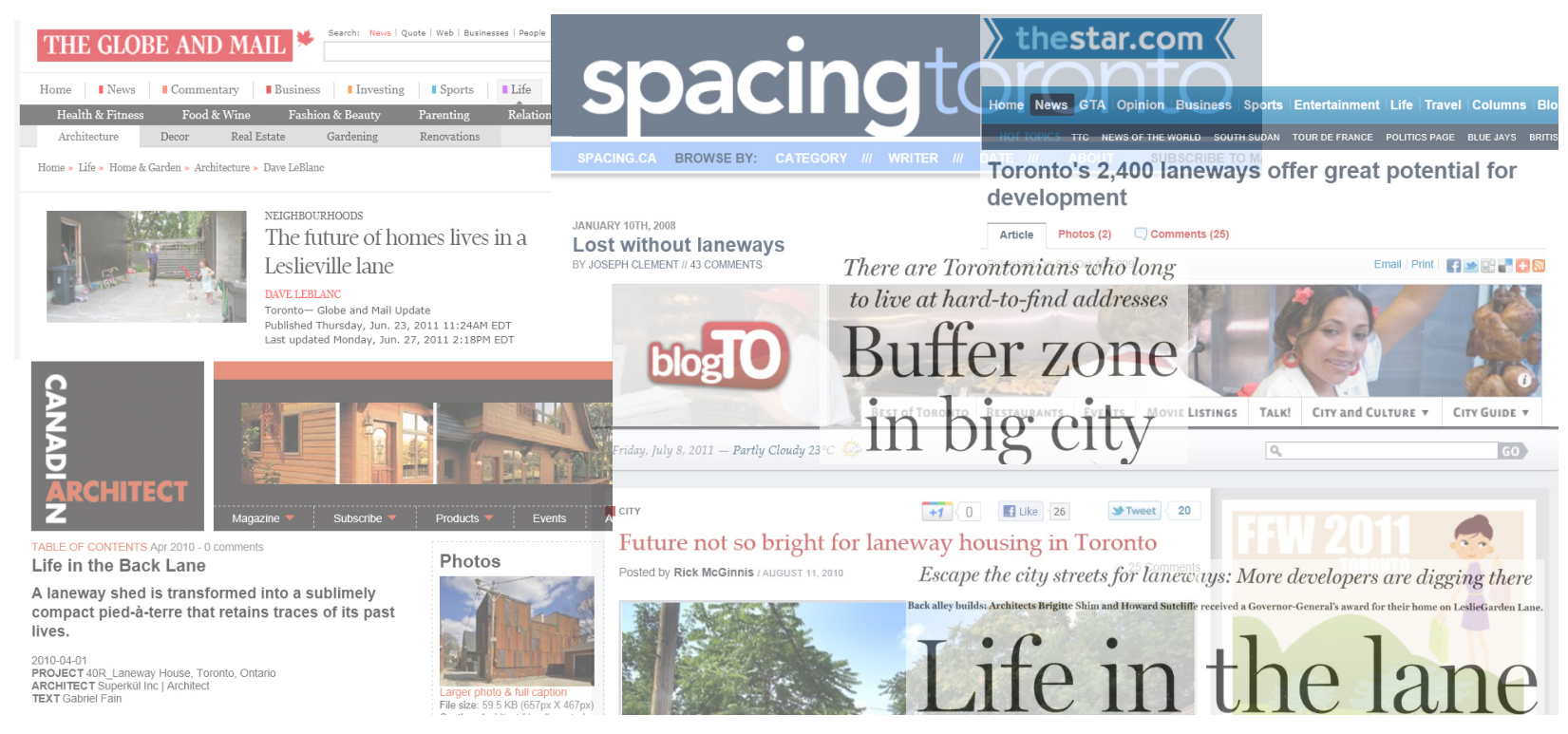

Having these layers and parallels are what makes cities amazing places to be...that you can discover corners that you never thought existed - it gives it layers that a city like Toronto desperately lacks. Cities like Rome that have all these layers and collisions of different things happening, you can really experience that, and if the laneways were developed that's what you'd get in the city - layers of experience.

Peter Tan as cited in (McGinnis, 2010).

2009

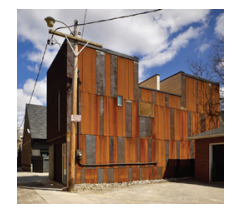

2007

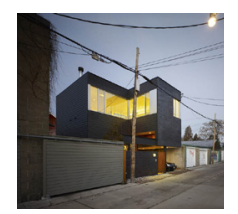

2003

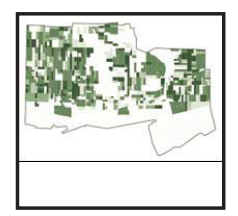

2001
City of Toronto Urban Design Award

40R_Laneway

Award of Excellence: Building in Context - Private - Low-scale building

Project Team: Superkül inc | architect

Figure 2-37

\section{City of Toronto Urban Design Award}

Laneway House

Honourable Mention Building in Context - Private Low-scale building

Project Team: Kohn Shnier Architects

Figure 2-38

\section{City of Toronto Urban Design Award}

Laneway Architecture and Urbanism

Visions and Master Plans - Award

Architect: Professor Brigitte Shim with Donald Chong

together with University of Toronto Masters of Architecture students

Figure 2-39

City of Toronto Urban Design Award

Award of Excellence - Buildings

1 Ways Lane

Architect: A.J. Diamond, Donald Schmitt and Company
Figure 2-40 


\section{Toronto's Laneway Housing Policy}

Toronto's laneway infrastructure is extensive, it can support a housing typology that can alleviate demographic and environmental issues, and a growing interest amoung the city's residents is slowly resurrecting these places. However, the City of Toronto's stance on laneways and laneway housing is skeptical and unsupportive. The destructive development pattern of the 1960s in Toronto which cleared many inner city residential neighbourhoods in favour of high-rise/high-density development resulted in a 1972 Central Area Plan that called for the "virtual stop of development of middle class inner city neighbourhoods" (Myers \& Baird, 1978, p. 20). As a result, subsequent Official Plans for the City of Toronto, including the most recent one, have discouraged any form of infill development in established residential neighbourhoods.

\section{SECTION 4 - REGULATIONS APPLYING TO ALL USE DISTRICT}

(11) RESIDENTIAL BUILDINGS: FRONTAGE ON A PUBLIC HIGHWAY, MINIMUM FRONT LOT LINE, HOUSE BEHIND A HOUSE

(a) No person shall erect or use a residential building otherwise than on a lot having a minimum front lot line of 3.5 metres fronting or abutting a highway assumed for public highway purposes, other than a lane laid out in the rear of lands abutting a highway or an outlet connecting the lane with a highway.

(b) No person shall erect or use a residential building in the rear of another building.

(c) No person shall erect or use a building in front of another building as to produce the condition of a residential building in the rear of another building.

(d) Paragraphs (b) and (c) do not prevent the erection of additions to the front or rear of an existing building provided the additions are so located and constructed as to form a part of and be used in conjunction with the original building.

(e) For the purposes of this subsection, residential building includes a hotel and the residential portion of a mixed-use building.

Figure 2-42 By-law 436-86 Section 4 (11)a specifically prohibits the construction of laneway houses in the City of Toronto.

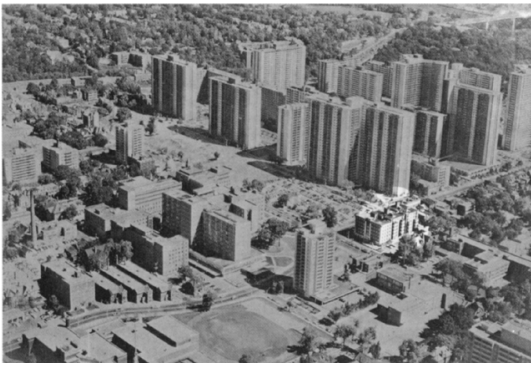

Figure 2-41 The St. James Town development Toronto, constructed in the 1960 s required the clearing of existing inner city neighbourhoods. Later recognized as destructive and bad planning.

\section{- IHE DENSE-CrTy. \\ 1 if alleys ane no longer being used for their indended purpose, perhaps its time to reclaim them." 47.}

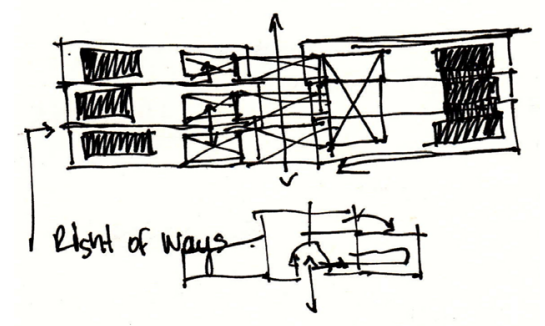

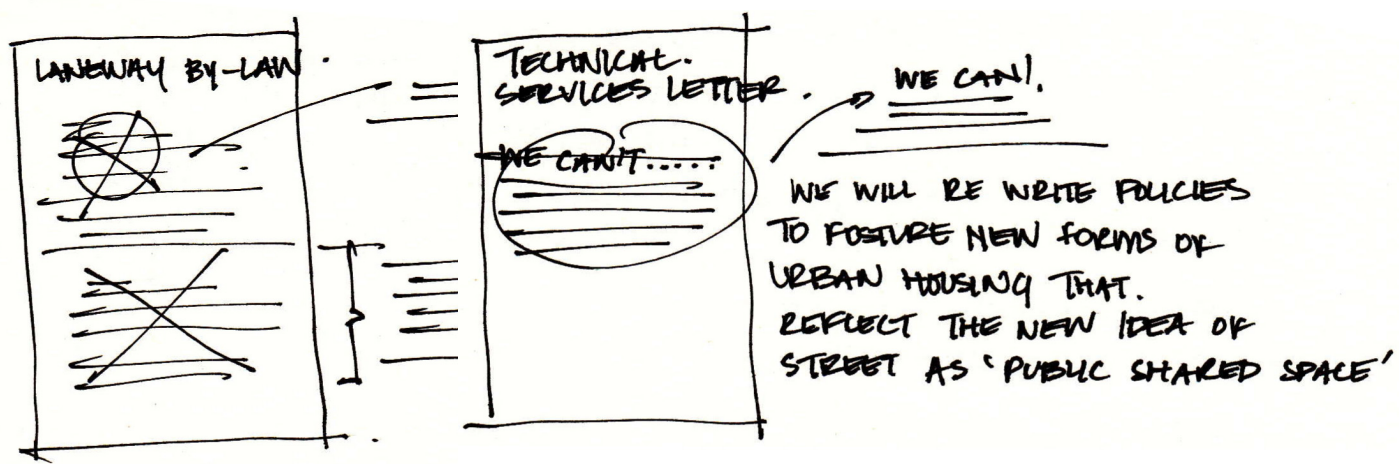




\section{Cities that allow Ancillary \\ Dwelling Units (ADUs)}

- Washington, USA - 13 cities including Seattle

- Vancouver, BC

- Portland, Oregon

Cities considering ADU's

- Bellevue

- Denver, Colorado

- Madison,

- Wisconsin

- Calgary, AB

\section{Learning from Precedent}

Policies and laws are only as valid as the times in which they are created; eventually they become obsolete and need to evolve for the sake of supporting, not deterring, the organic growth of cities. As a result, planning policy should change and be adapted accordingly. Laneway housing development in Toronto has yet to be approved because of dated planning policy that continues to be seen as relevant by those who refuse to believe that solutions exist to the issues surrounding this type of development. While the City of Toronto does not recognize the opportunities available in laneway housing approval, numerous North American cities have approved laneway housing (also referred to as ancillary dwellings, granny suites, backyard cottages) as a densification strategy and to provide unique housing opportunities for their residents.

\section{Vancouver's Approval of Laneway Housing}

Vancouver is the only Canadian city to have approved laneway housing in all areas. Considered the most sustainable city in Canada, it is not surprising then that Vancouver's approval of laneway housing came about as a sustainable strategy under the EcoDensity Charter adopted by City council in 2008. Containing significant land restraints, Vancouver investigated unique densification strategies to deter sprawl development and offer an alternative to high-rise/high-density development. Laneway housin was recognized as a "hidden density [that] provides an exceptional opportunity for incremental densification and new affordable housing options within residential neighbouhoods" (EcoDensity, Initial Actions, p. 18) and was approved by Vancouver's city council in 2009.

Since the approval of this housing typology a considerable amount of laneway housing projects have been emerging throughout the city, bringing with them the formation of specialized designbuild firms and a steady income for the City as well as for property owners. 


\section{Summary}

Laneways, which have been forgotten for decades are slowly making a resurgence. The implementation of these urban networks as opportunities for spatial reform through infrastructure improvements, greening initiatives and residential development are redefining the laneway program and once again making them usable and inviting places in the existing urban system. Policy amendments, made by some cities, are allowing for people to call these laneways home. The hope is that one day the same will be possible for the laneways of Toronto. The following portion of this thesis' intention is to prove that laneway housing development is possible within Toronto's existing urban fabric. Using The Study of Laneway Housing in Toronto (Stinson \& Van Elslander, 2003) and the City's of Vancouver and Seattle as a foundation, this thesis argues that the 'adverse impacts' of laneway housing depicted by the City of Toronto are solvable through unique design solutions and that this housing typology can successfully fit into Toronto's urban context. 
1. Prove 


\section{Prove: It Can Be Done}

In order to explore the potential emergence and evolution of laneway housing on Toronto's urban form, the specific building typology must be understood in relation to the lots on which it would be constructed and the 'adverse issues' surrounding this building typology.

Toronto's historical development, in relation to lot division, varied throughout the city (see figure 3-01 ). As a result, the city contains differences in lot sizes. For the purpose of this exploration, three different urban blocks containing laneways were chosen, from three different locations in the Old (pre-amalgamated) City of Toronto (see figure 3-02 ), whose lot sizes and built form reflect their historical emergence and provide different urban form variables.

Based on the information gathered in A Study of Laneway Housing in Toronto [A.S.L.H.T.] (Stinson \& Van Elslander, 2003) and the approval of laneway housing and backyard cottages in Vancouver and Seattle, the following exploration attempts to prove that laneway housing development is possible within Toronto's existing urban fabric.

While the technical issues surrounding laneway housing are just as important as the non-technical issues, the following exploration concentrates on the former. Keeping in consideration the technical issues, this thesis argues that the City of Toronto should not view the technicalities of laneway housing development as 'adverse issues' that deter this type of development, but as opportunities. Opportunities to allow for more unique and sustainable housing development by improving our cities urban form, existing infrastructure and expanding city services rather than concentrating on the construction of new infrastructure that supports unsustainable suburban sprawl development.

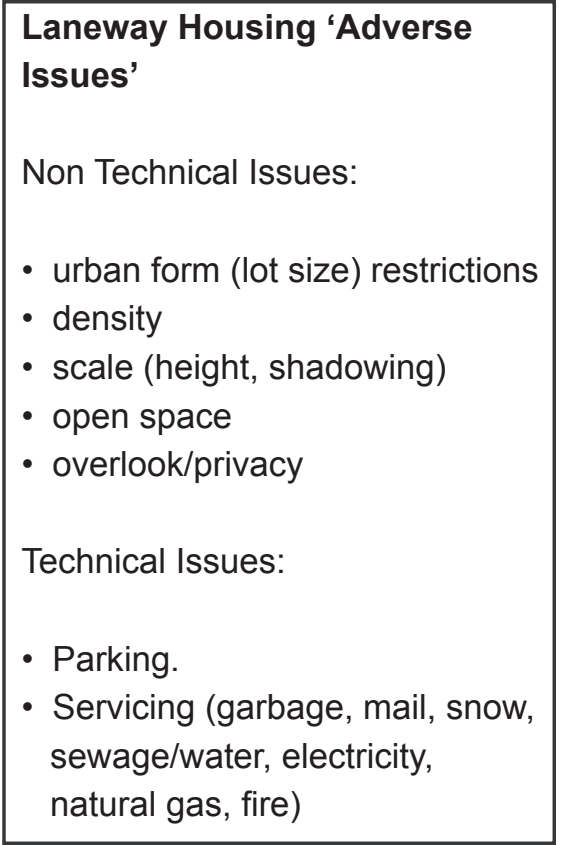

Potential Solutions to Technical Issues surrounding L.W.H. development.

Parking:

-carshare.

Servicing:

-smaller vehicles, or the consolidation of all services.

\section{THIS IS (NOT) A LANEWAY. ENVISIONING TORONTO'S FUTURE MID-BLOCK COMMUNITIES. September 16, 2011. By: Maya Janikowski. Supervisor: Miljana Horvat.}




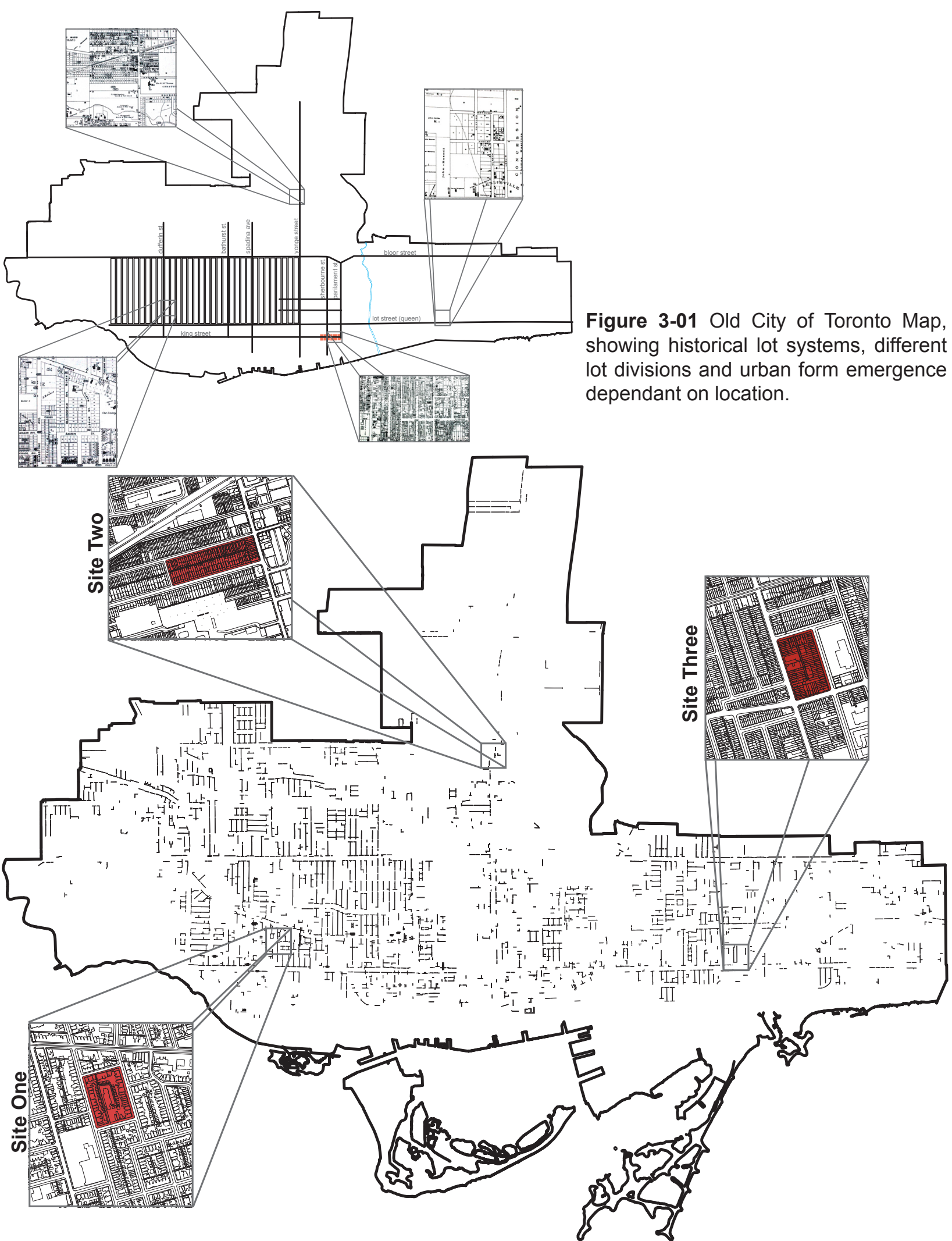

Figure 3-02 Old City of Toronto (Pre-Amalgamated) boundaries highlighting three different chosen design exploration urban blocks containing laneways for design exploration. 


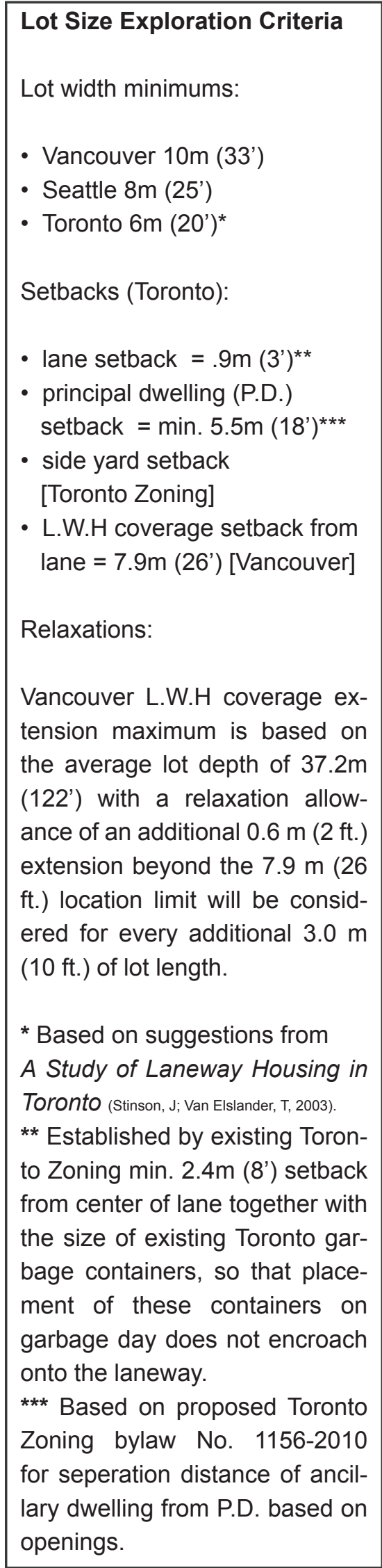

\section{Urban Form (Lot size) Restrictions}

The purpose of the lot size restrictions exploration was to examine what the achievable laneway housing lot coverage could be based on the exploration criteria gathered from A.S.L.H.T. and Vancouver and Seattle examples. The conclusions are that based on the identified criteria, even though both Toronto's short and long lots have a significantly more restrictive urban form than Vancouver and Seattle's lots, they can still accommodate the precedent criteria and therefore support the laneway housing typology.
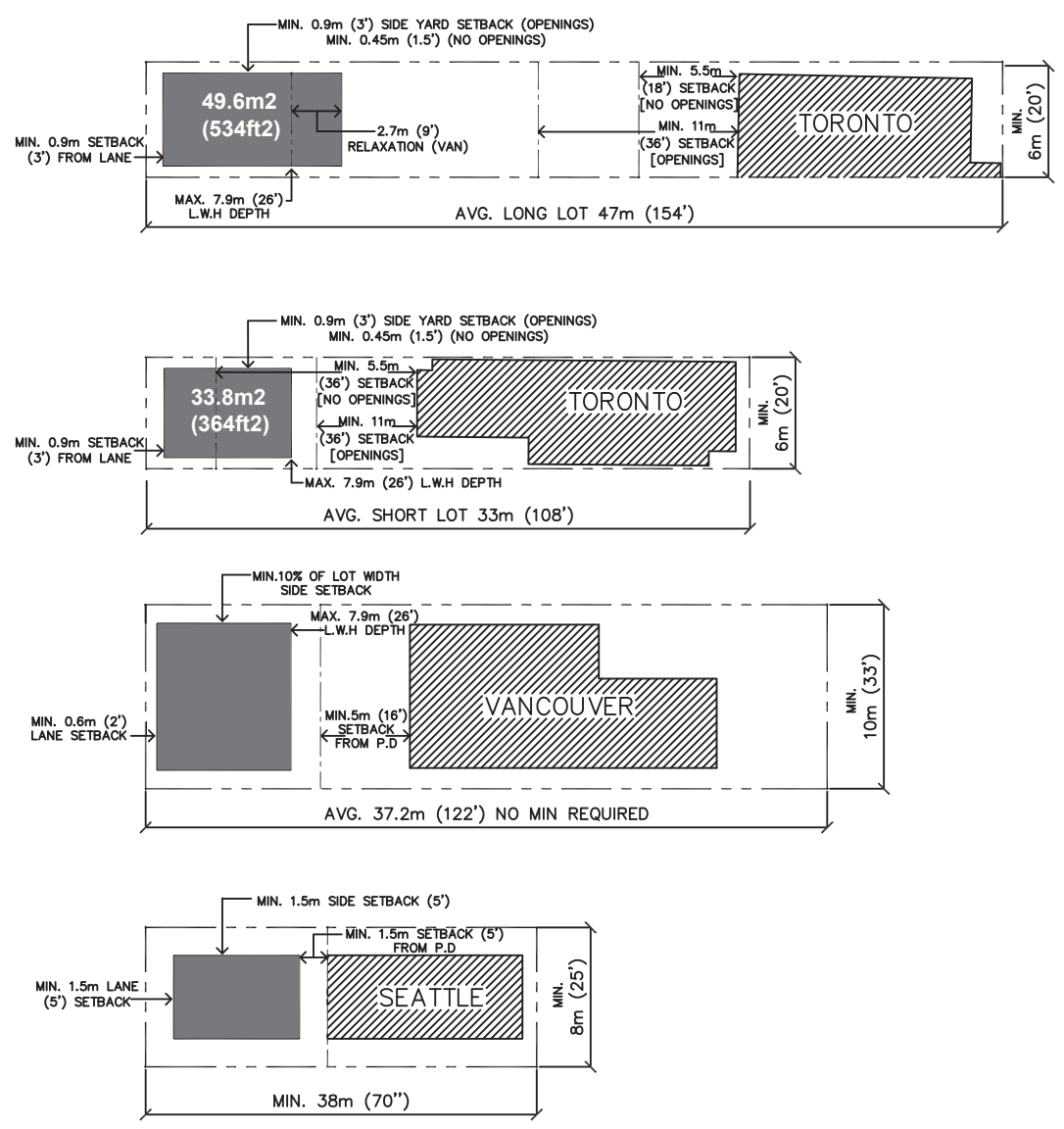

Figure 3-03 Lot size restriction comparison exploration based on setback and lot minimum requirements for L.W.H. allowance. Does not take into consideration lot coverage maximums. 


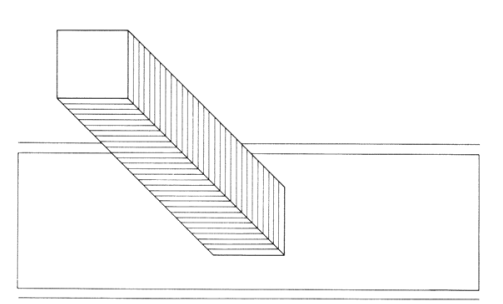

कासे सित्रा

4 婴

and and as

Figure 3-04 Sherbourne lanes, density distribution comparison.

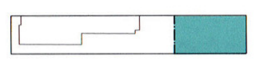

Single Lot, used: Severed

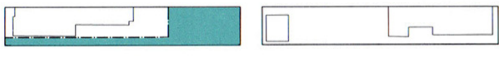

Single Lot, used: Severed with keyhole
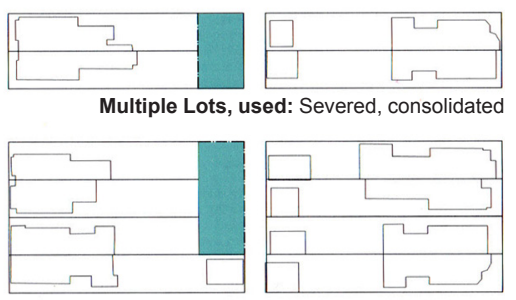

Multiple Lots, unused: Severed, consolidated

Figure 3-05 Potential laneway lot severance options.

\section{Density}

There is an existing negative predisposition to density, mostly based on the misconceptions that density increase cannot be sensitive yet appears only in high-density/high-rise form. However, the key to infill of any form is densification. The following section attempts to justify lot severance and density increase for the purpose of laneway housing development by arguing that lot subdivision has been part in parcel of Toronto's historical urban form development in order to increase density. Lot severance for the purpose of laneway housing development, would simply be an evolution of the same urban form development patterns. More considerate than high-rise/high density developments, laneway housing has the potential to increase Toronto's housing density significantly without destroying the existing character of Toronto's established neighbourhoods.

\section{Cities can absorb massive population increase and still be sustainable without jeopardizing future generations.}

(Rogers, 1997, p. 28 ). 

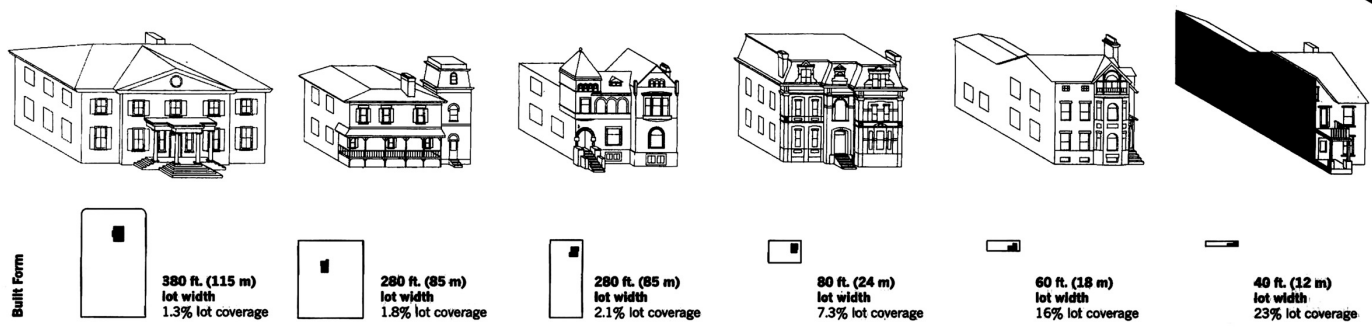

$280 \mathrm{ft.}(85 \mathrm{~m})$
lot witth
$1.8 \%$ lot coverage
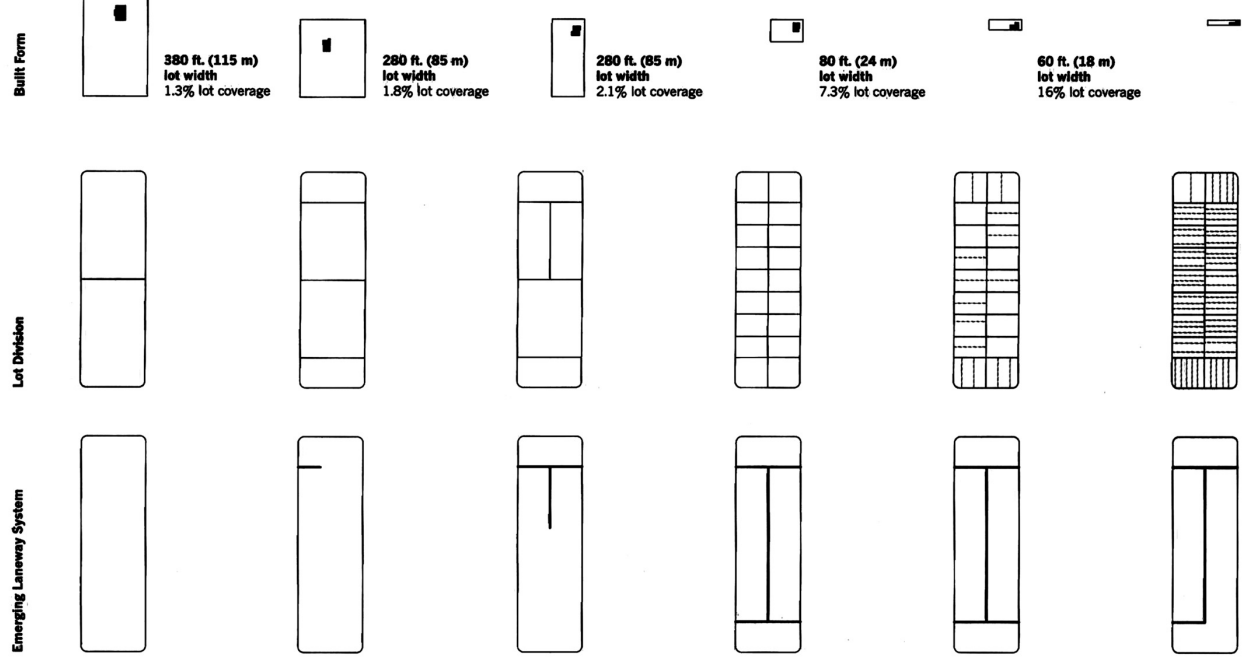

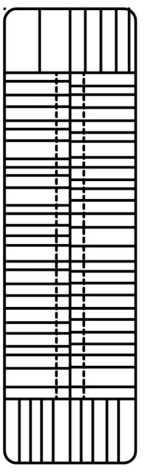

Figure 3-06 The historical evolution of Toronto's lot division. The last image on the right is an addition, showing the potential for Toronto's future lot subdivision to accommodate laneway housing development. 


$\begin{aligned} & \text { Housing Density Exploration } \\ & \text { Criteria }\end{aligned}$
- min. lot width of $6 \mathrm{~m}\left(20^{\prime}\right)^{*}$
- min. P.D. setback of $5.5 \mathrm{~m}$
$\left(18^{\prime}\right)^{* *}$
- max. $30 \%$ existing lot
coverage ${ }^{* * *}$ (challenged).
- lot severance \& consolidation
* A.S.L.H.T. established that any
lot below $6 \mathrm{~m}$ (20') in width is un-
suitable for L.W.H. development,
unless consolidated with another
lot to increase width.
** Based on Toronto Zoning
bylaw No. $1156-2010$, no L.W.H.
will infringe on this minimum P.D.
separation.
$* * *$ Based on suggestion from
A.S.L.H.T.

Housing Density Potential (L.W.H. Infill)

The cities of Vancouver and Seattle have established maximum lot coverages for their ancillary dwelling unit [A.D.U.] to regulate density levels as well as restrain the sizes of the A.D.U.'s in order to guarantee competitiveness on their housing markets. A.S.L.H.T. (Stinson \& Van Elslander, 2003) also makes the suggestion that laneway housing development should not be considered on lots with an existing building coverage of over $30 \%$. However, due to the differences in Toronto, Vancouver and Seattle's lot size averages, laneway housing potential would be meagre if these cities lot coverage maximums were implemented on Toronto. The existing coverage of the majority of Toronto's residential neighbourhoods is already very close to or above $30 \%$, providing only $5-10 \%$ of these lots to be severed and considered for laneway housing development based on A.S.L.H.T. recommendations (Stinson \& Van Elslander, 2003). As a result, the following exploration lightly challenges A.S.L.H.T.'s suggestions of an existing coverage of $30 \%$ to determine how many more lots could be opened up to laneway housing potential.

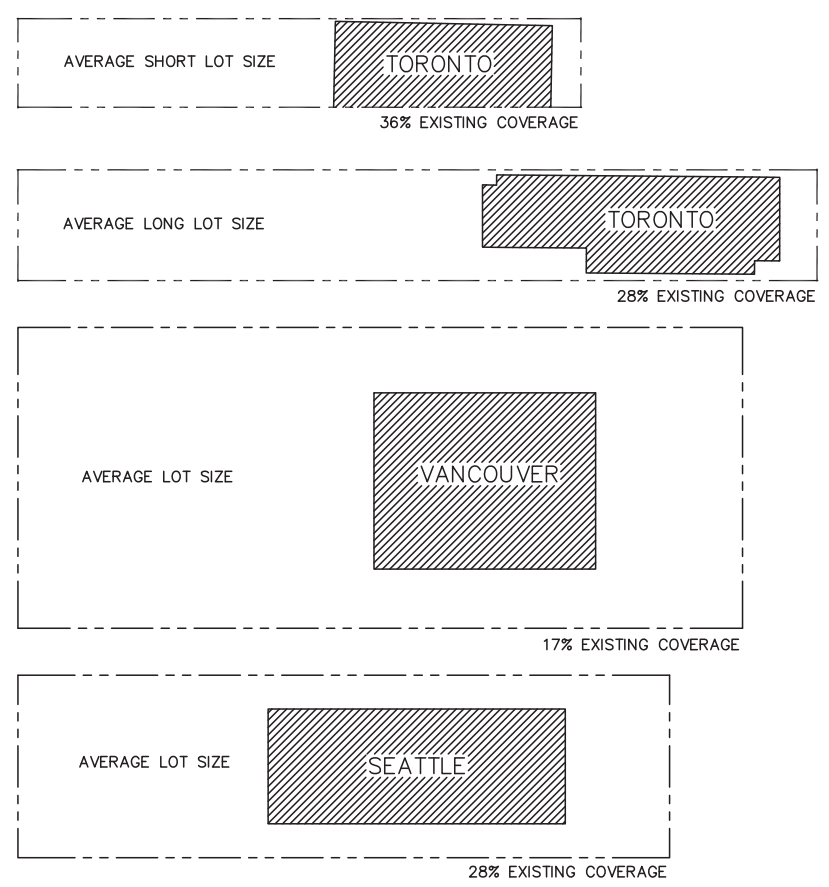

Figure 3-07 Average Lot Sizes and existing coverage. 


\section{Legend}

Grade A Infill opportunity - Existing lot width is greater than $6 \mathrm{~m}\left(20^{\prime}\right)$ \& existing lot coverage is less than $30 \%$. Established setback specifications are maintained.

Grade B Infill opportunity - Existing lot width is greater than 6m (20') \& existing lot coverage is greater than $30 \%$. Established setback specifications are maintained.

Grade C Infill opportunity - Existing lot width is less than $6 \mathrm{~m}\left(20^{\prime}\right)$ and only favourable for consolidation lot infill. Established setback specifications are maintained.

No Infill opportunity - Existing lot width is less than $6 \mathrm{~m}\left(20^{\prime}\right)$ and cannot be consolidated with a neighbouring lot. Established setback specifications cannot be achieved.

Existing L.W.H. unit

Potential L.W.H. unit

Existing parking garage

Existing Commercial/Institutional Land

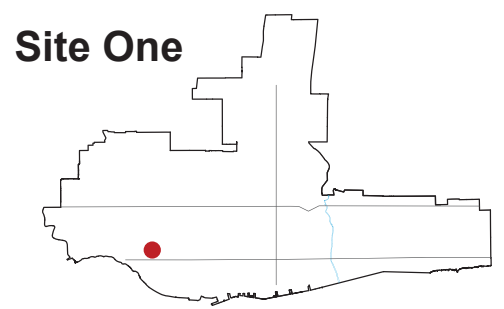

Existing Site Built Form

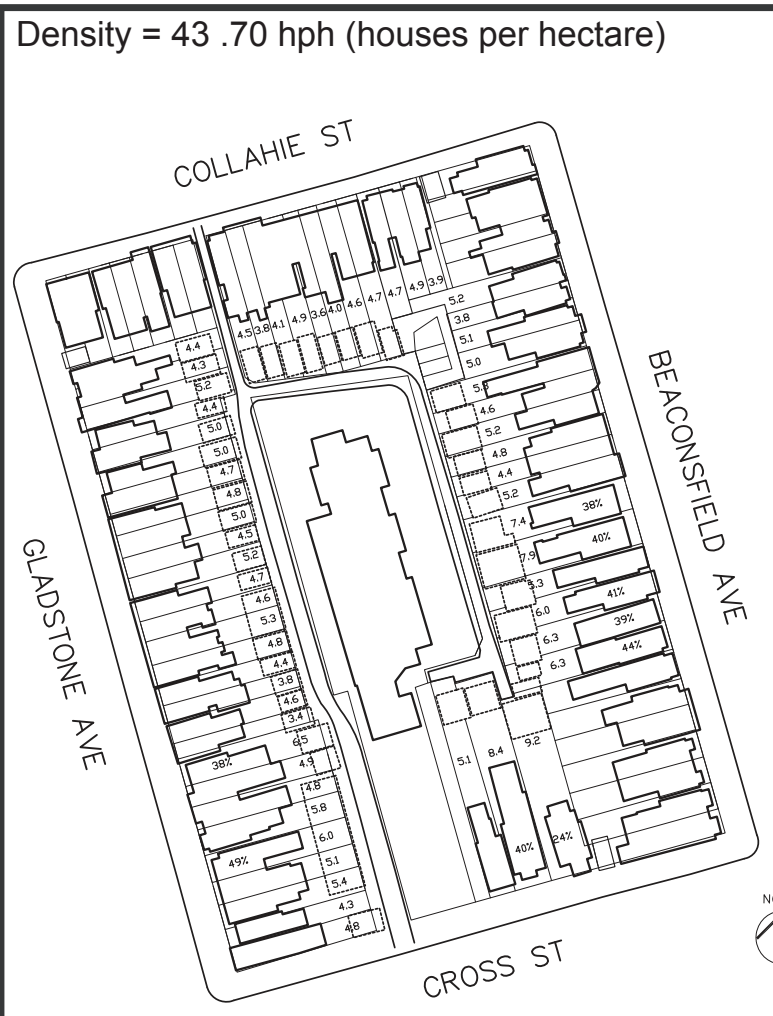

Potential Site L.W.H. Built Form
Density $=55.62 \mathrm{hph}$

An increase of $27 \%$ or $11.91 \mathrm{hph}$

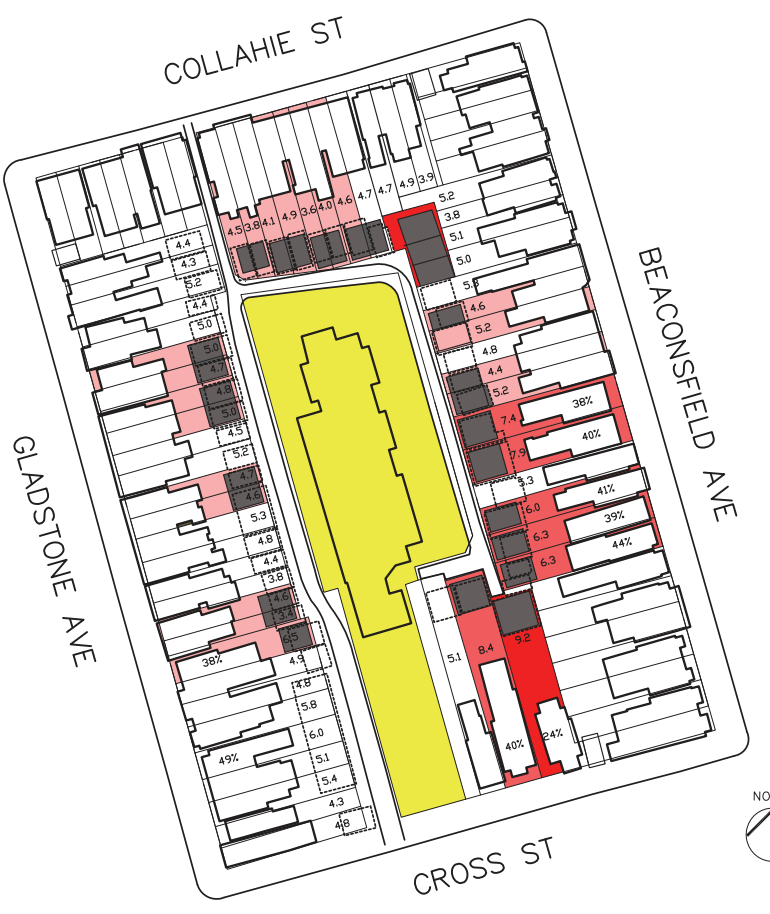

Figure 3-08 Site One Existing and Proposed Housing Density. 


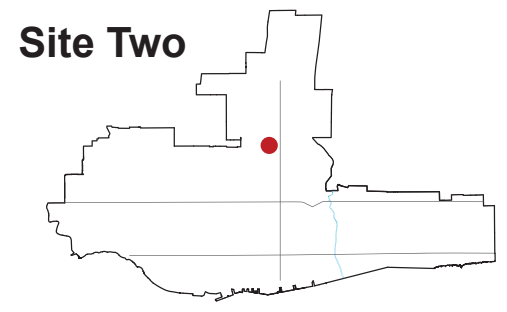

\section{Existing Site Built Form}

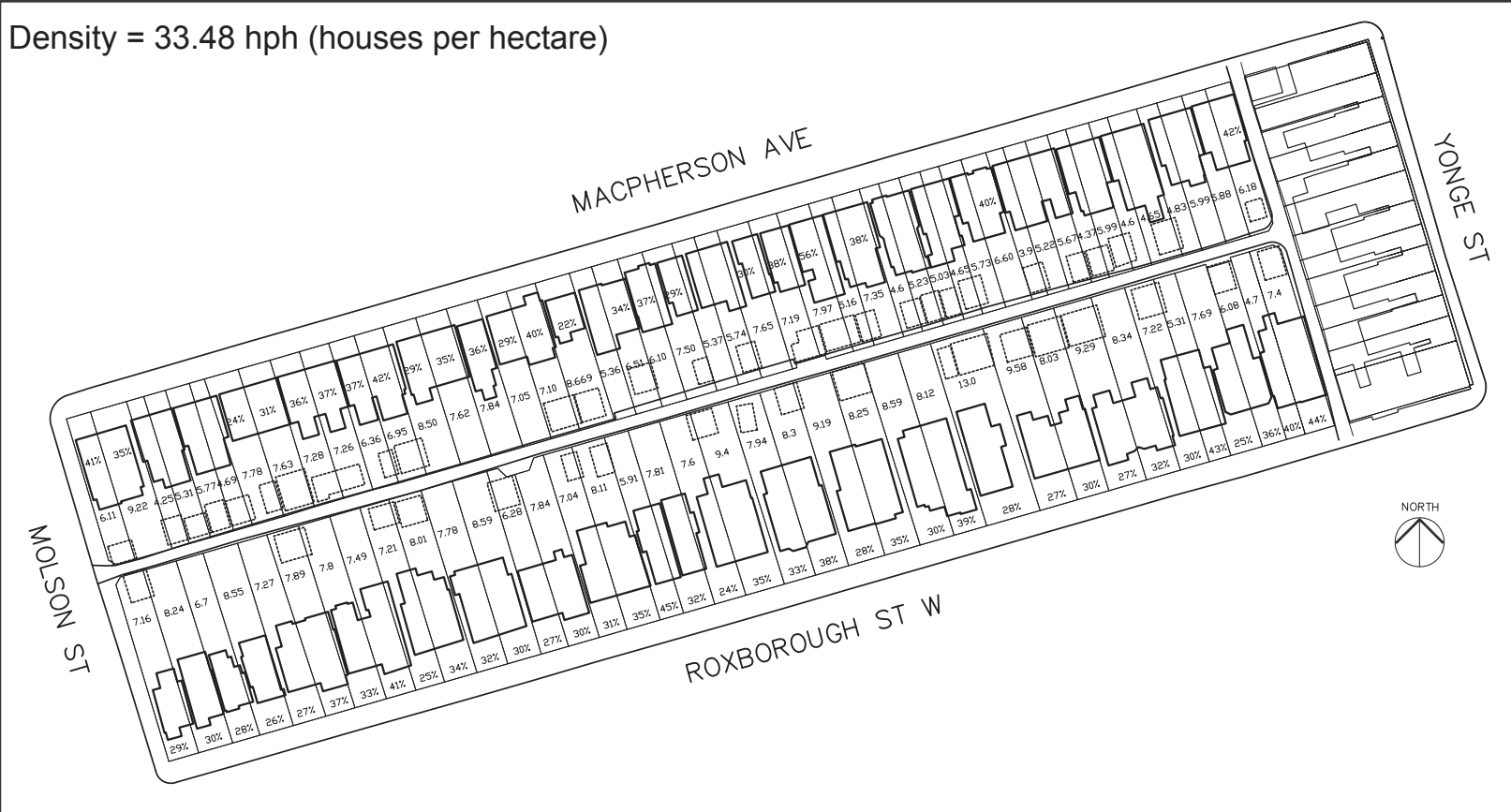

\section{Potential Site L.W.H. Built Form}

Density $=60.48 \mathrm{hph}$

An increase of $79 \%$ or $27 \mathrm{hph}$

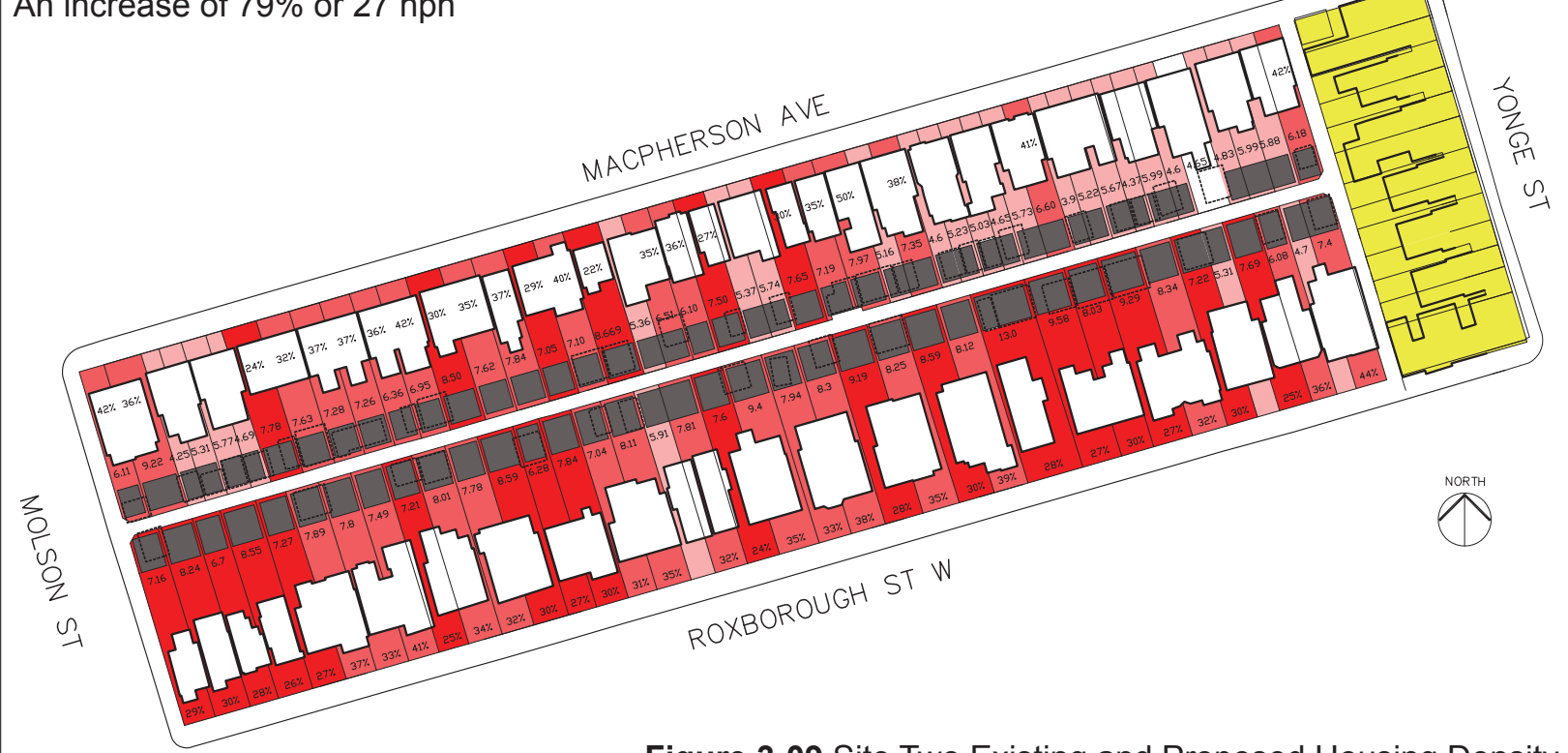

Figure 3-09 Site Two Existing and Proposed Housing Density. 


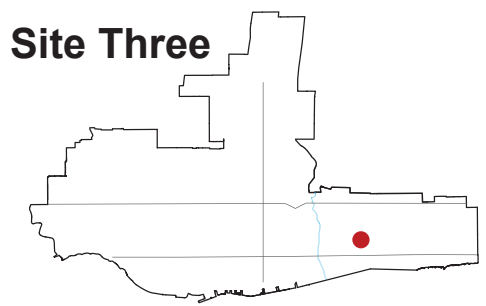

Existing Site Built Form

Density $=39.46$ hph (houses per hectare)

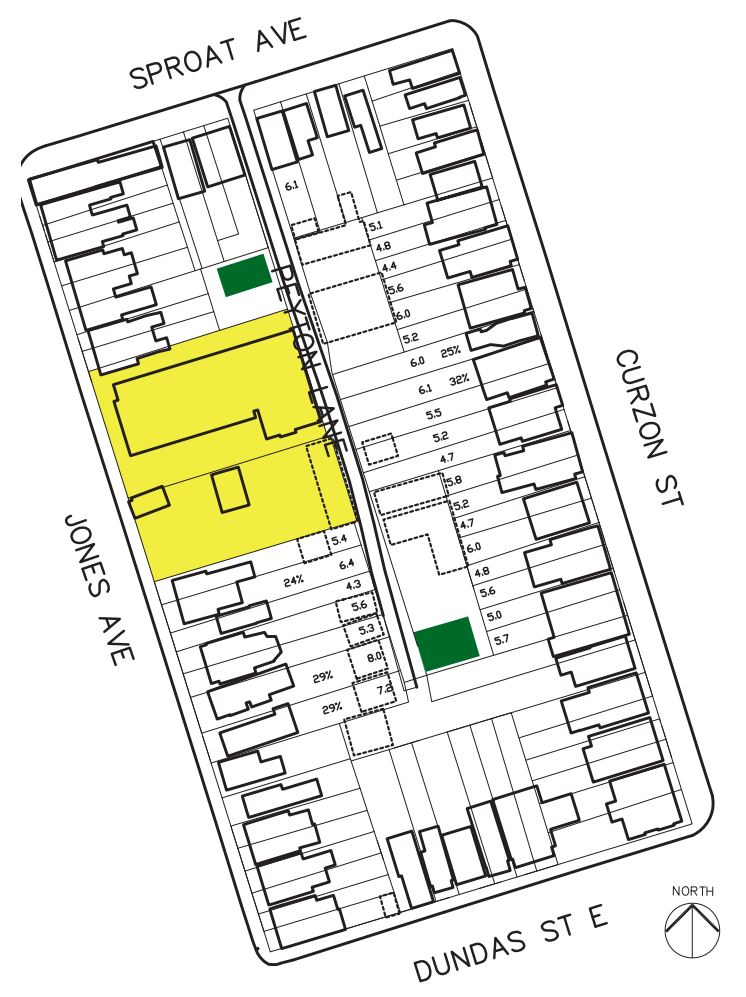

Potential Site L.W.H. Built Form

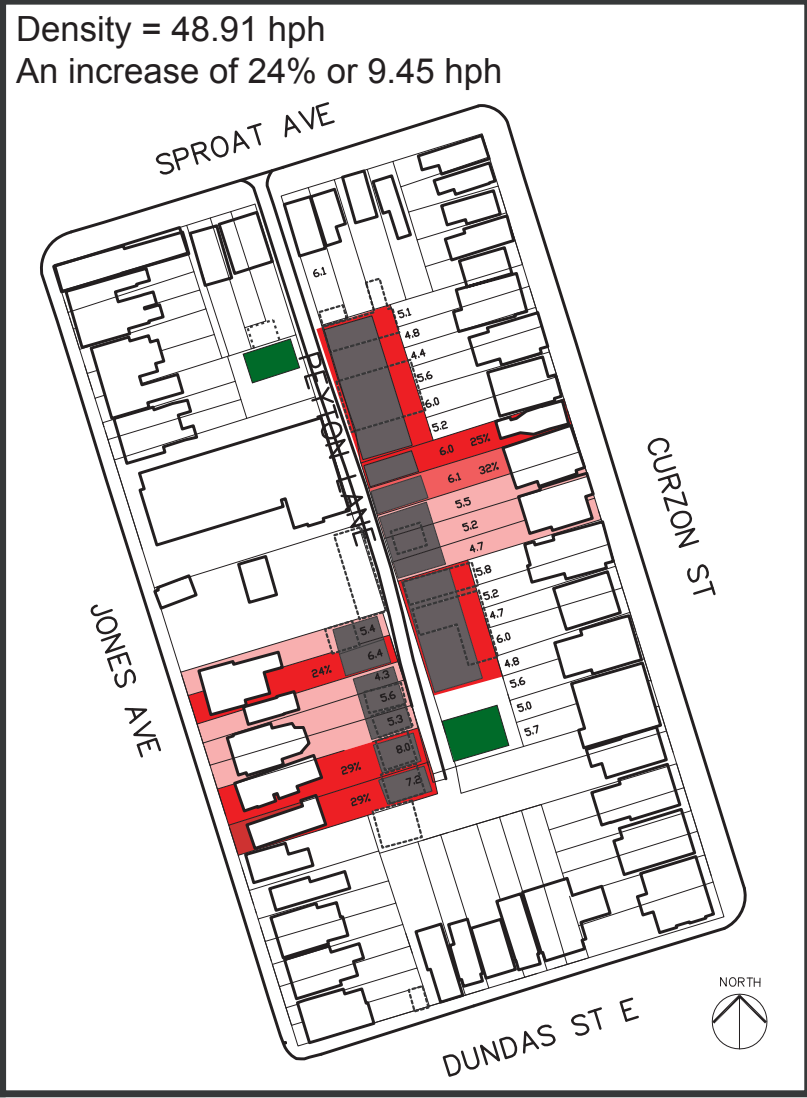

Figure 3-10 Site Three Existing and Proposed Housing Density.

\section{Conclusions}

Though the coverage of the existing study sites would significantly increase if lot severance, consolidation, and laneway development occurred, the principal dwelling setbacks, based on the established Toronto Zoning criteria, as well as open space, and therefore access to daylighting, are still maintained. The result of this exploration is a significant increase in household density. However the form of the laneway housing typology is much smaller than the existing housing typology and therefore would support a smaller household size. The increase in dwellings does not necessarily mean a significant increase in the amount residents and the benefits of density relaxation would allow for the construction of the highly demanded ground related housing typology as well as satisfy smart growth initiatives. 


Scale Characteristics
- Height.
- Massing.
- Shadowing.
- Relation to principal dwelling.

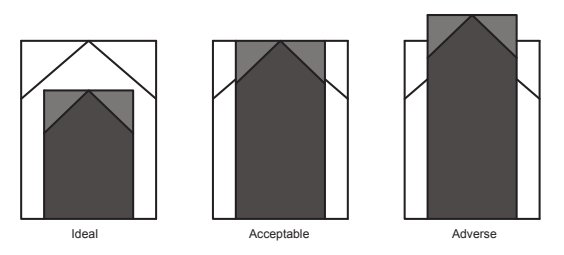

Figure 3-11 A.D.U. scale in relation to principal dwelling.

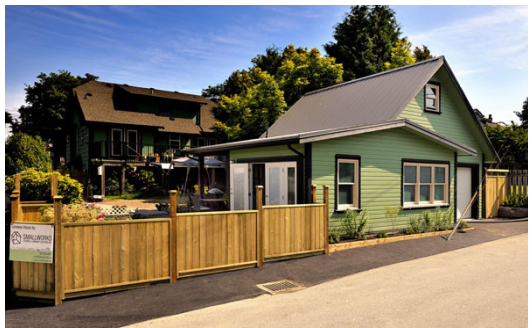

Figure 3-12 Vancouver L.W.H. (foreground) in relation to principal dwelling.
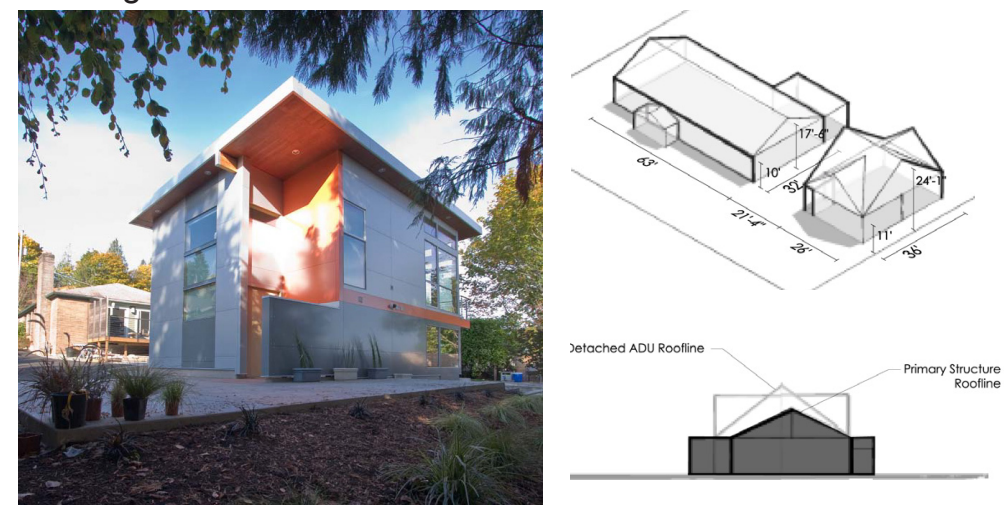

Figure 3-13 Seattle back-yard cottage (foreground) in relation to principal dwelling.

\section{Scale} 71).

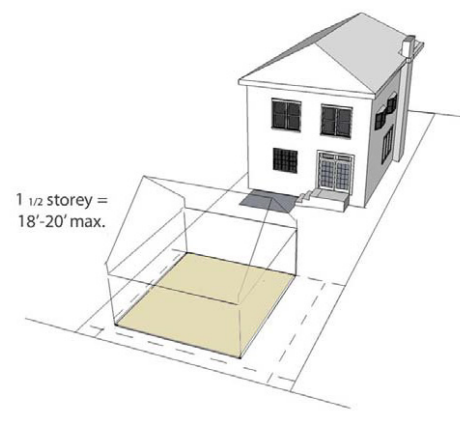

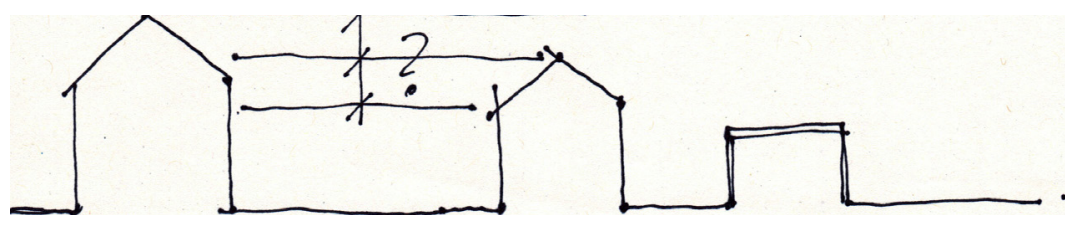

The scale of a laneway house is the most critical characteristic of its design due to how it relates to surrounding buildings and open spaces (Stinson \& Van Elslander, 2003). The height, massing and proportion of a laneway house can determine its acceptance into a neighbourhood based on whether it appears overwhelming in relation to the existing context or casts shadows on surrounding buildings. Avi Friedman suggests that the most important determination of an A.D.U.'s appropriate scale is its ability to be subordinate to the principal dwelling and therefore acceptable to surrounding residents (Friedman, 2002, pg

Figure 3-14 The City of Vancouver maintains strict scale restrictions for their L.W.H. proposing that they should not exceed the footprint of the existing garage and should not be taller than 1.5 storeys (with height relaxations on larger lots) in order to maintain a subordinate nature in relation to the existing principal dwelling and neighbourhood.

Figure 3-15 The City of Seattle, on the other hand, also regulates the heights of their backyard cottages, however Seattle's height restrictions are not as stringent as Vancouver's, and the backyard cottage scale in relation to the principal dwelling is not regulated to be subordinate. 
Height Determination Through Shadow Studies

When determining the height of an ancillary unit such as a laneway house, consideration must be taken to examine the effects of sun access and shadowing effects on the principal dwellings building structure as well as its open space (such as backyard gardens). With Toronto's residential lots having different orientations as well as depths, the principal dwellings will observe varied effects from the height of a laneway house. The following pages contain shadow studies to determine the shadow and sun access to the principal dwelling based on different laneway house heights, lot depths, and orientations.

The conclusions from the shadow studies show that a universal height cannot be determined for all of Toronto's lots due to their varying depths and orientations. As a result, sun/shadow studies should be conducted separately for different laneway house locations to determine the ideal height and potential setback locations, taking into consideration the importance of minimizing shadowing effects on the laneway as well, as this is the largest usable open space for laneway housing residents.
Shadow Study Characteristics

- Lot orientation

- Lot depth

- $6 \mathrm{~m}$ (2 storey L.W.H. height).

- $6 \mathrm{~m}$ second storey recessed.

- 9m (3 storey L.W.H. height).

Shadow Study Conclusions

Short lots

North/South orientation

- 1.5 storey $(4.5 \mathrm{~m})$ max height.

East/West orientation

- 1.5 storey $(4.5 \mathrm{~m})$ max height or;

- 2 storey $(6 \mathrm{~m})$ max height with second floor setback from P.D.* depending on specific circumstances.

\section{Long Lots}

North/South orientation

- 2 storey $(6 \mathrm{~m})$ max height (conduct shadow study to determine if second storey requires a setback from P.D.)*

East/West orientation

- 2 storey $(6 \mathrm{~m})$ max height.

* Vancouver L.W.H. guidelines

suggest a min. of $1.2 \mathrm{~m}\left(4^{\prime}\right)$.
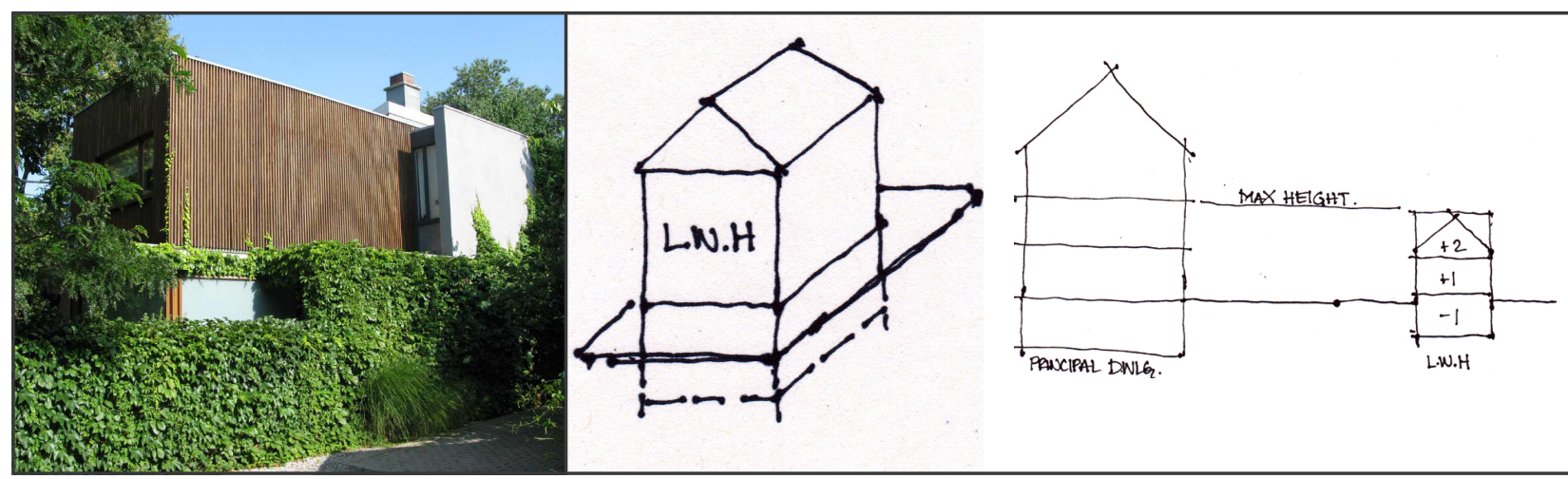

Figure 3-16 Innovative ways of dealing with laneway housing height restrictions. 7 Leslie Garden Lane is a wonderful example of how subordinate height considerations were maintained while maximizing interior floor space by sinking the dwelling into the ground. 
Figure 3-17: North/South Short Lot - L.W.H. Height Shadow.

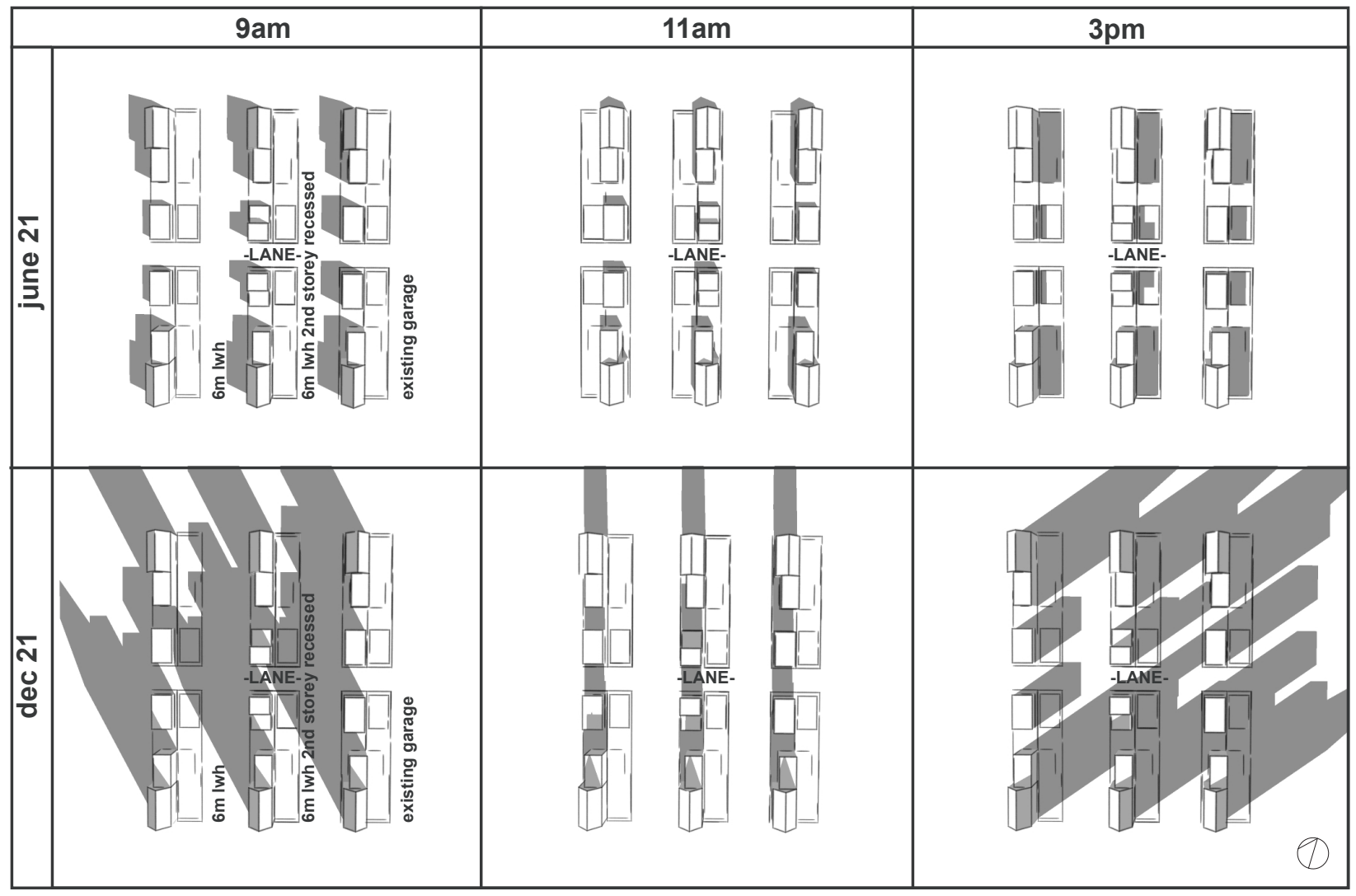

Figure 3-18: East/West Short Lot - L.W.H. Height Shadow.

(1)


Figure 3-19: North/South Deep Lot - L.W.H. Height Shadow.

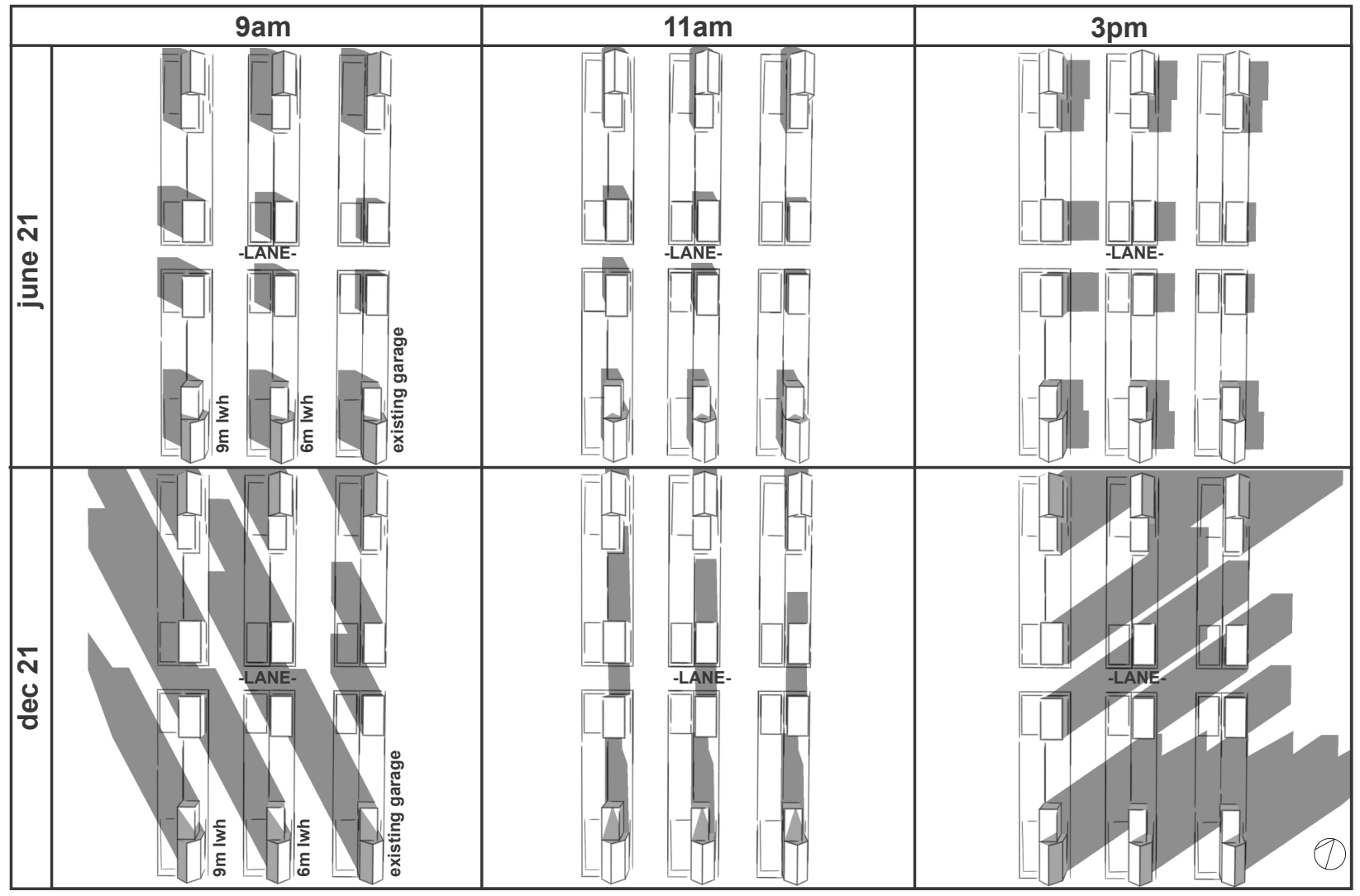

Figure 3-20: East/West Deep Lot - L.W.H. Height Shadow.

(11)




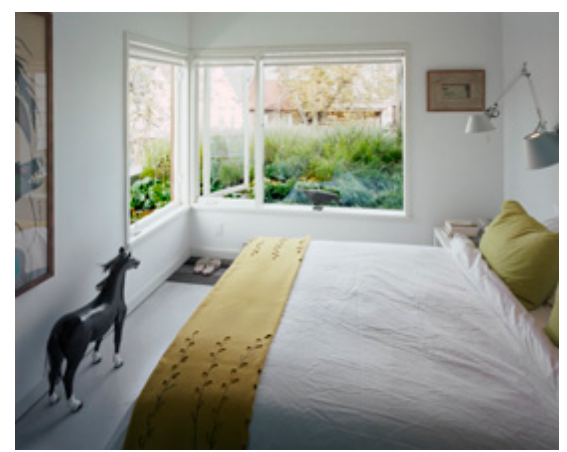

\section{Privacy / Overlook}

One of the main deterrents from laneway housing acceptance by existing neighbours is the fear that infill projects such as laneway houses pose privacy and overlook issues. However, by orientating the majority of the glazing towards the laneway and maintaining small window proportions on the back side

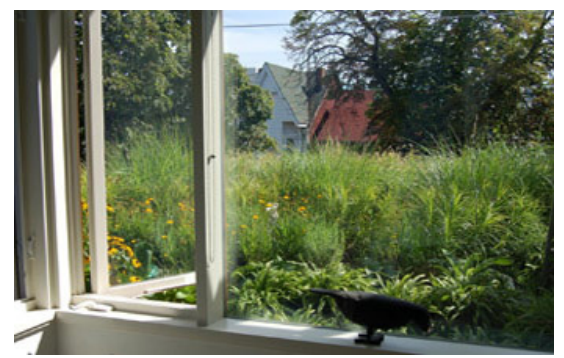
of the laneway dwelling (for ventilation and day-lighting) these issues can be avoided. Vancouver laneway housing specifications go as far as to suggest that if there are any green-roofs on the side of the principal dwelling, no door and stairway access can be designed to allow for this space to be usable as an outdoor space. Backyard wall features and natural elements can

Figure 3-21 Levitt Goodman infill house, with greenery providing privacy and protecting from overlook.

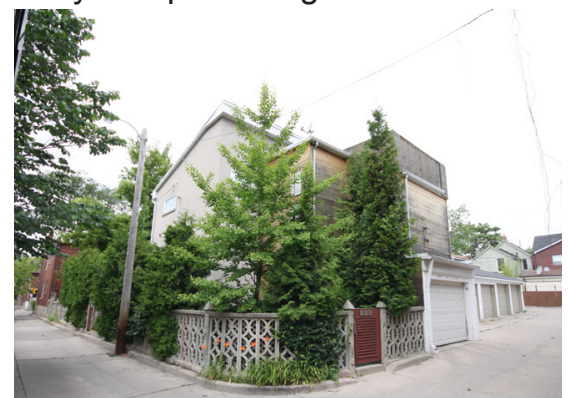

Figure 3-22 Toronto L.W.H. exterior garden protected by greenery.

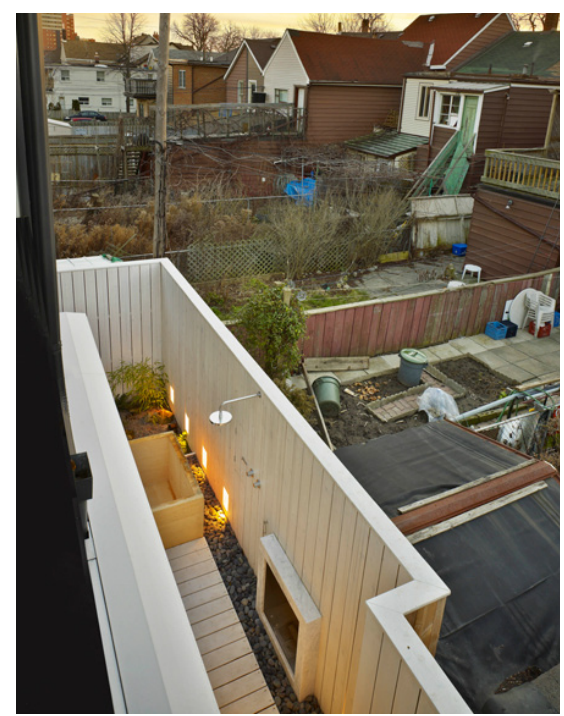

Figure 3-23 Kohn Shnier Architects L.W.H. with enclosed backyard.

provide privacy buffers between the two dwellings as well as appropriately designed shading devices that allow daylight, yet deter direct views.

The majority of picture (view) windows should face the laneway.

Green space should be achieved through landscaping any openspace and providing a green roof to maximize permeable sur-

Open space should be limited to patios facing the lane and privacy protected back yard space. Roof top terraces should be considered when height and space restrictions permit.

Figure 3-24 Glazing, green space and open space locations to maintain privacy and deter overlook. 


\section{Open Space/ Day-lighting}

Due to the lot restrictions of ancillary dwellings such as laneway houses, designing for adequate open space is an important aspect of achieving desirable living conditions in such dwellings as, "access to sunlight and air positively affects housing quality" (Stinson \& Van Elslander, 2003). Vancouver and Seattle's laneway specifications, as well as A.S.L.H.T. suggest numerous options for achieving open space requirements in ancillary dwelling units such as side gardens on wide lots, patio's and decks, and backyard spaces when the depth of the lot permits. Height restrictions on laneway housing dwellings cause difficultly in providing open space such as rooftop gardens, however good design proves that even small areas have potential for great open spaces.
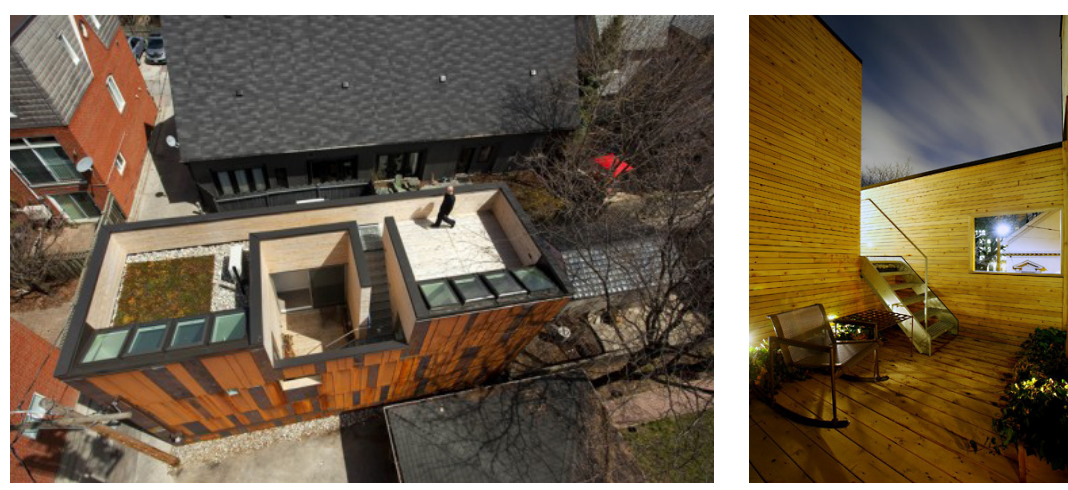

Figures 3-26, 3-27 Open space achieved through micro-courtyard design and garden terraces.

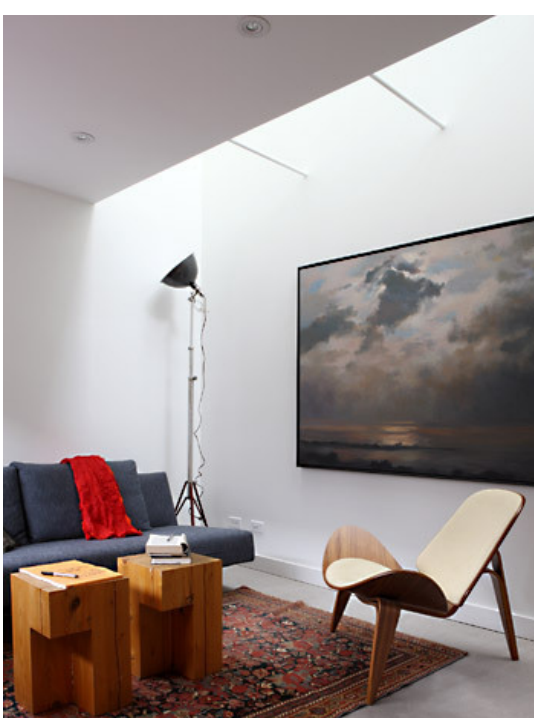

Figure 3-25 Day-lighting provided through sky lights.

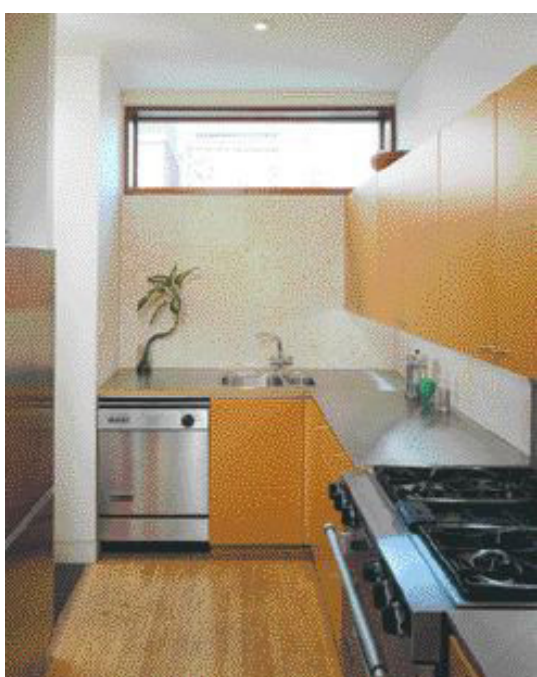

Figure 3-28 Day-lighting provided through high windows.
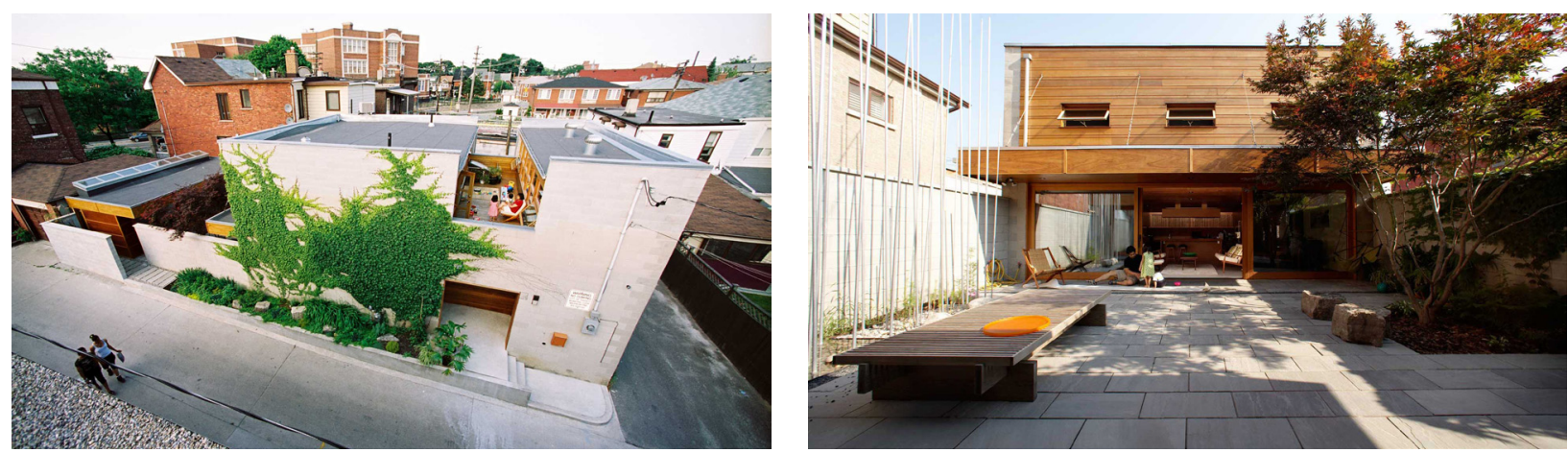

Figures 3-29, 3-30 Open space achieved through courtyard design and garden terraces. 


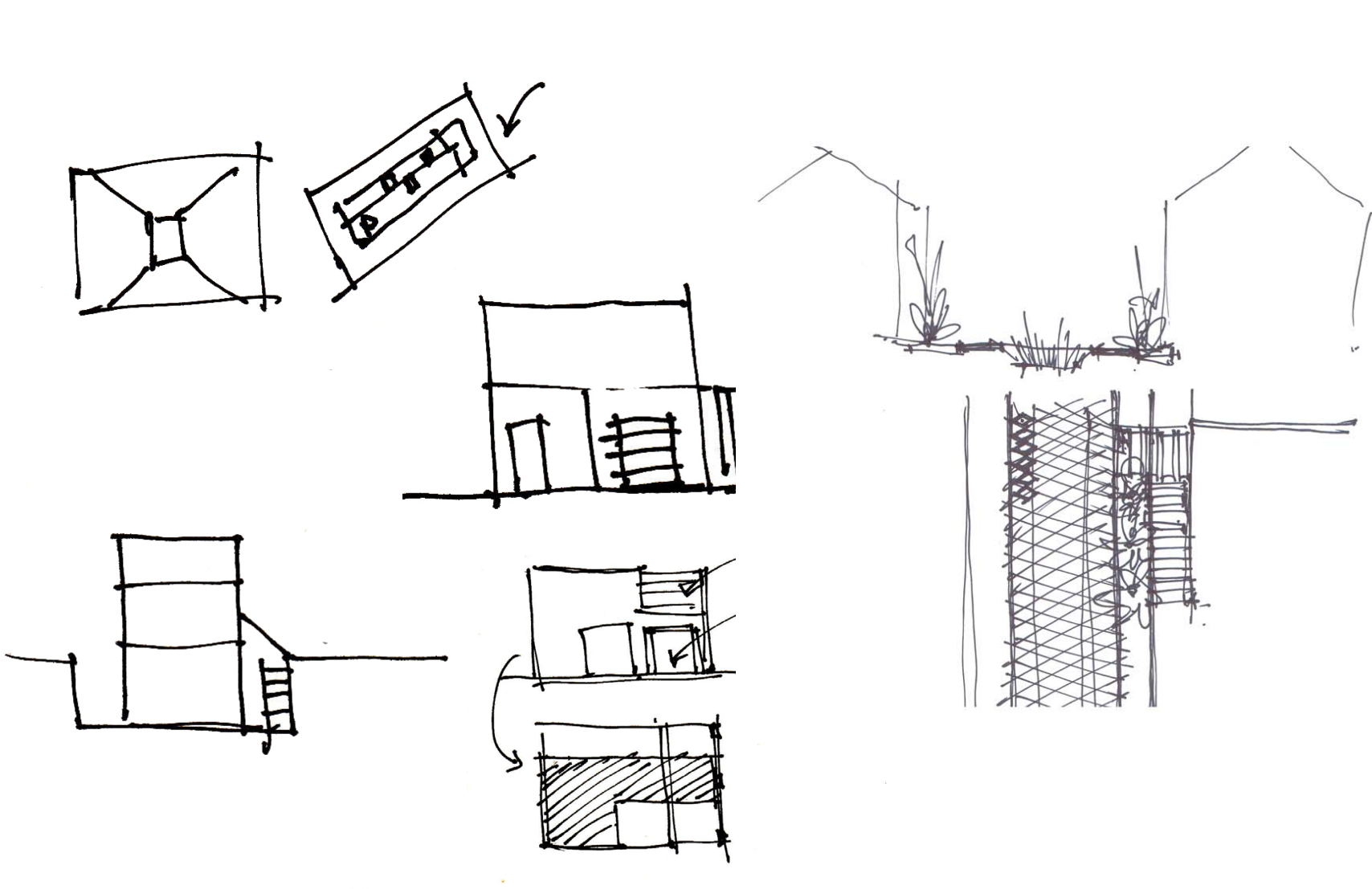

2. IMAGINE. 


\section{Imagine - What it Would Look Like}

The following is an exploration of laneway housing typologies on three different blocks in the City of Toronto. Using the information gathered in the previous section, regarding the 'adverse issues' surrounding laneway housing, the prototype laneway housing designs attempt to minimize these issues, while providing desirable interior spacial configurations, access to day-light and open space. The interior spacial configurations and unit sizes attempt to reflect potential laneway housing user groups. The purpose of this section is to imagine what the laneway housing typology could look like in the context of Toronto's urban form.
Design Methodology

Test 4 different laneway housing typologies on the 3 different chosen block typologies, reflecting needs of identified user groups.

\section{Design Considerations}

Lot restrictions (setbacks)

Height maximums

Open Space

Privacy/Overlook

Parking

\section{Housing Typologies}

Micro Rental

Single Family House

Live/Work House

Townhouse (Rowhouse)

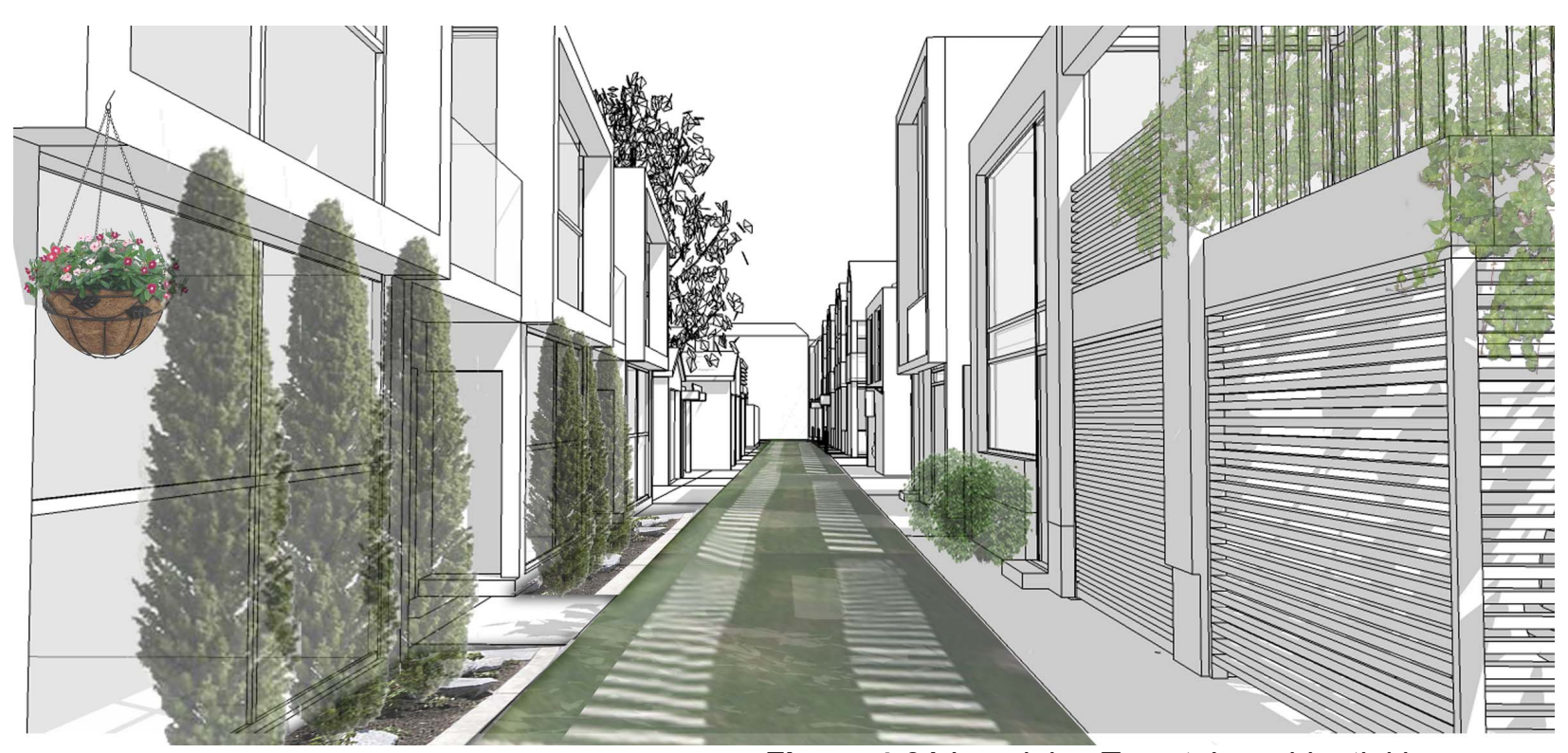

Figure 4-01 Imagining Toronto's residential laneways. 


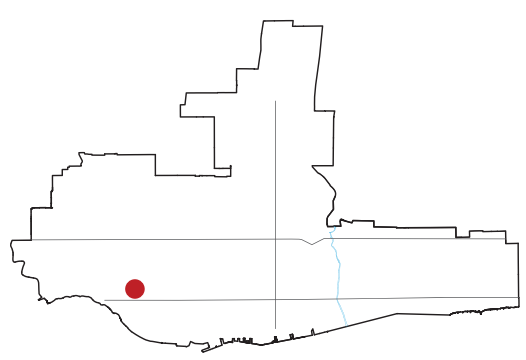

Potential User Groups

Singles

Scenario: Do not require a large space, but do not want to live in a high-density/high-rise apartment, and prefer to live in a detached ground related house located in a vibrant and established neighbourhood.

$65+$

Scenario: They are ready to downsize, but want to stay in their preferred neighbourhood in a ground related house and maintain the legacy of ownership.

\section{Site One - The Micro House}

The first test site is located in the western part of Old Toronto in an established residential neighbourhood. The back of the lot faces a laneway and a retirement home which is located on an island lot circled by the laneway. The existing block typology is dense, and the lots are what are considered short lots. However, based on the identified design considerations, a modest size two storey, one bedroom, one bath, no parking, laneway house can be supported by this site.

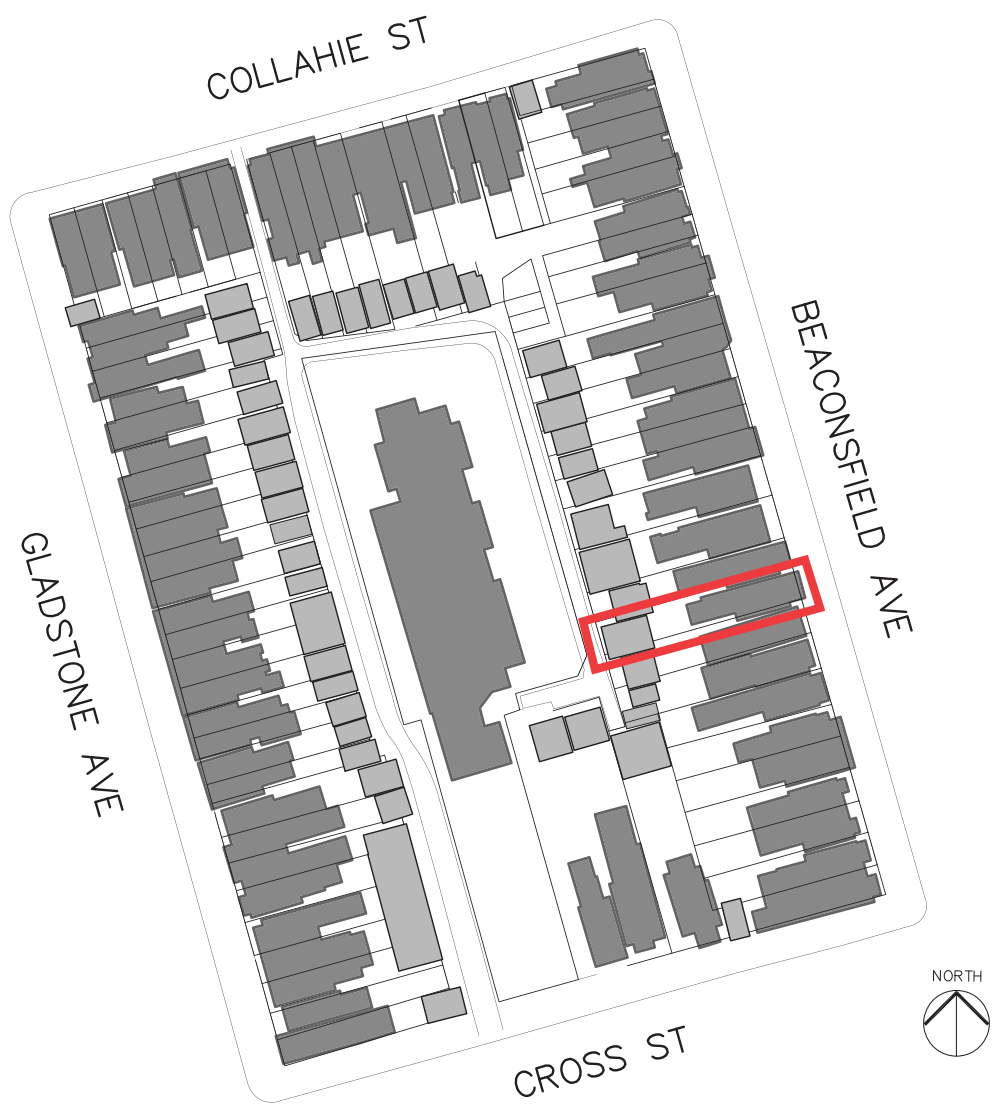

Figure 4-02 Site One block plan.

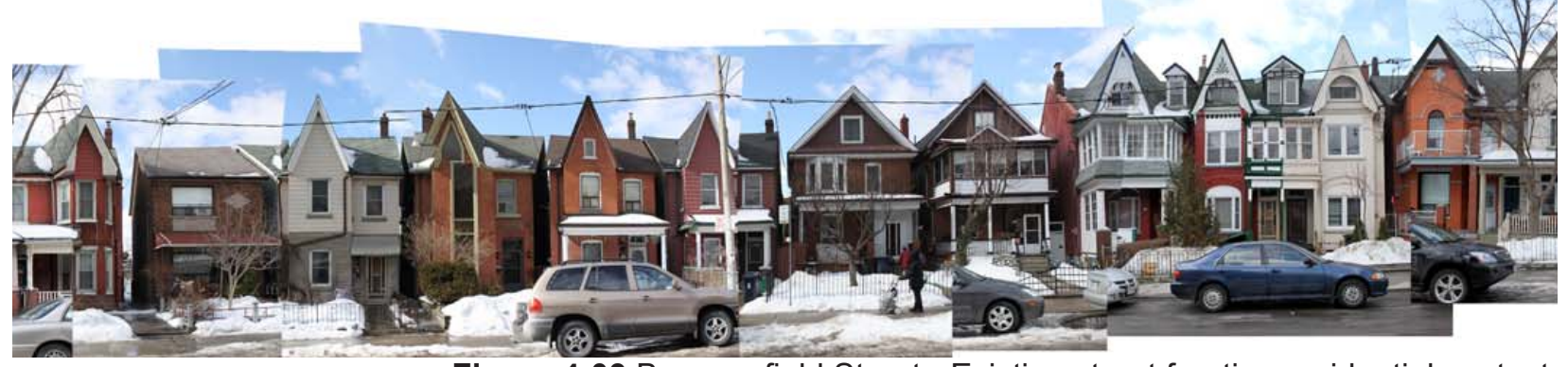

Figure 4-03 Beaconsfield Street - Existing street fronting residential context. 

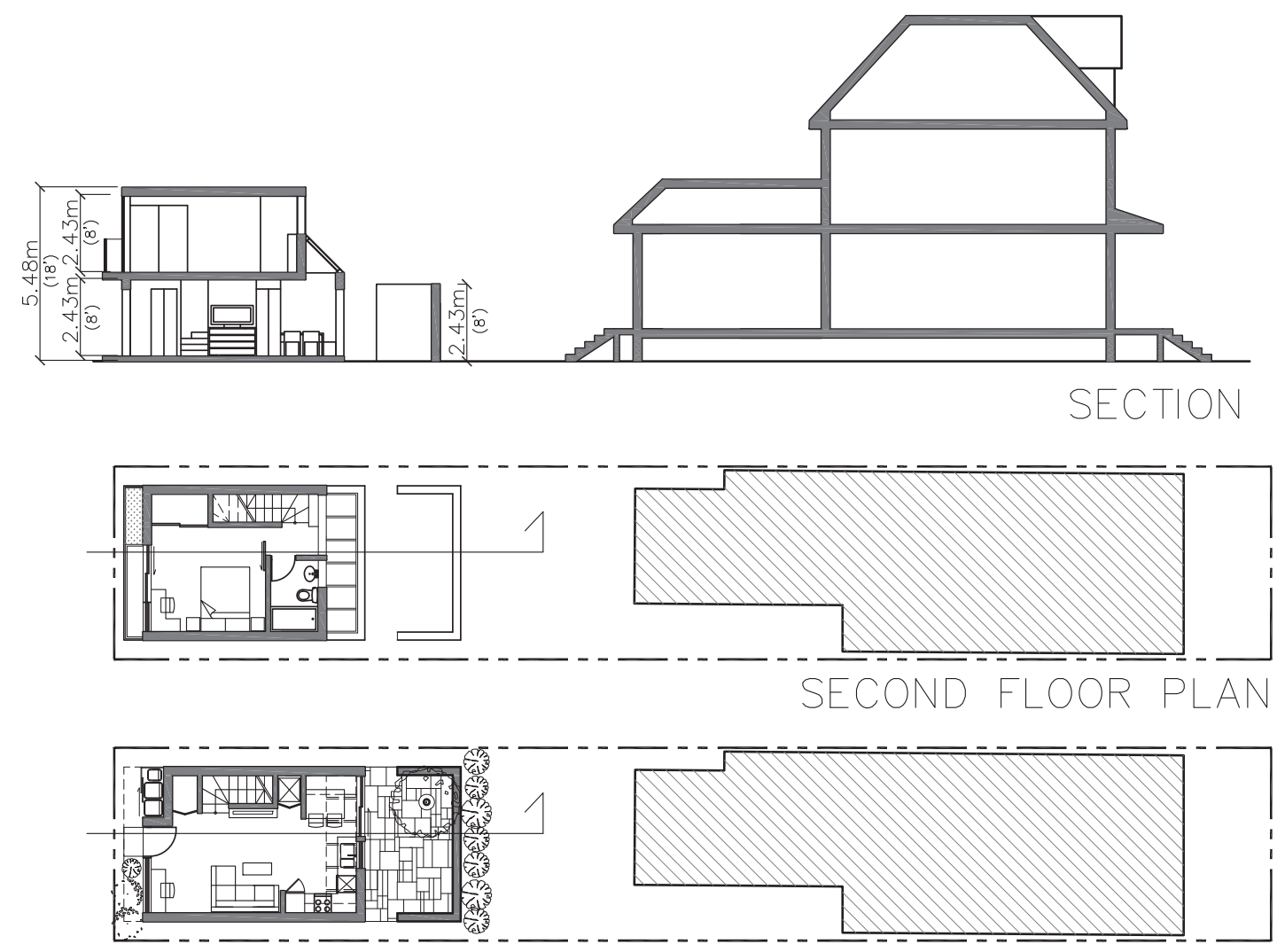

Total Area: $46.45 \mathrm{~m}^{2}\left(500 \mathrm{ft}^{2}\right)$
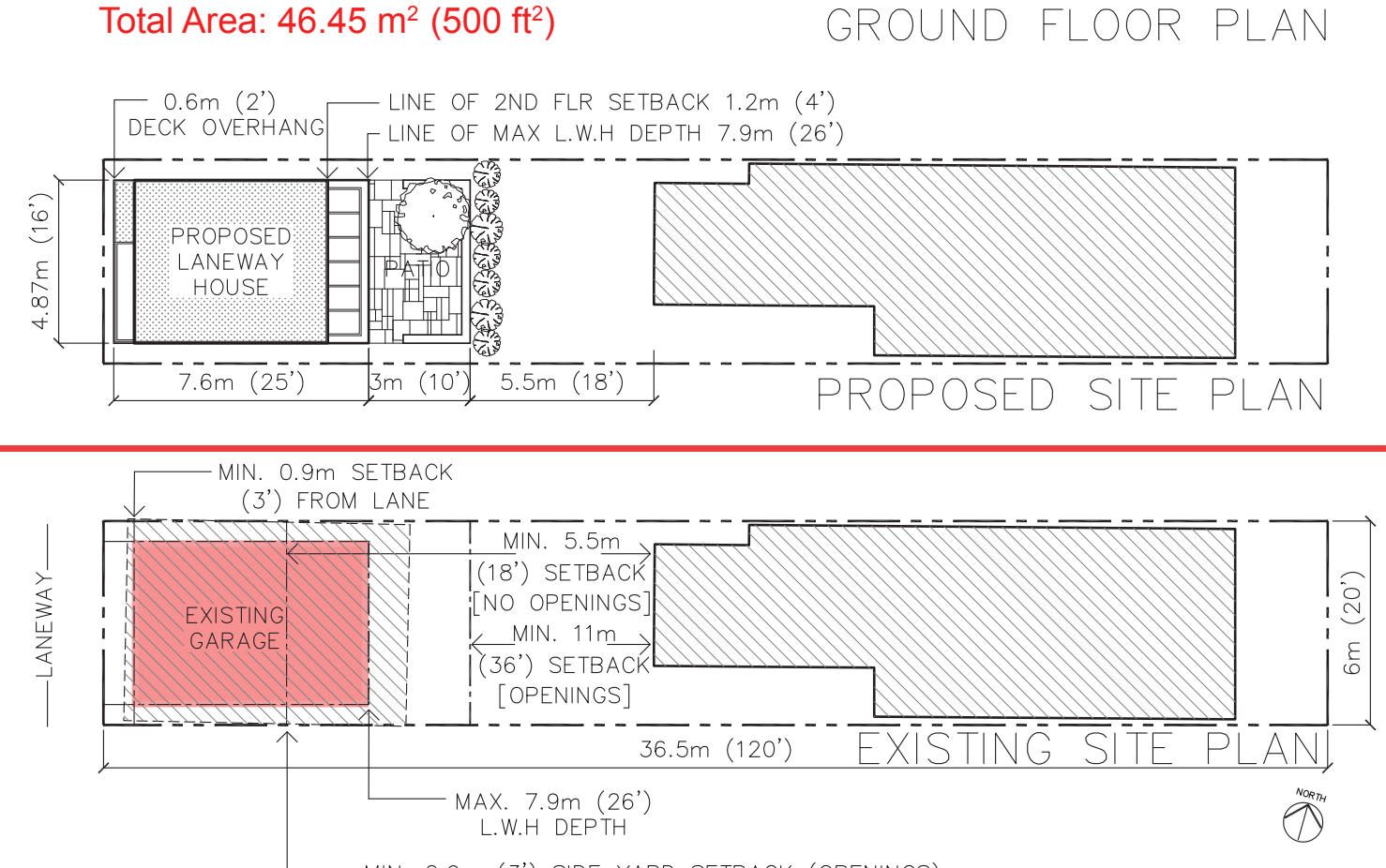

MIN. $0.9 m$ (3') SIDE YARD SETBACK (OPENINGS)

MIN. $0.45 \mathrm{~m}\left(1.5^{\prime}\right)$ (NO OPENINGS)

Figure 4-04 Site One - site and building plans and sections. 


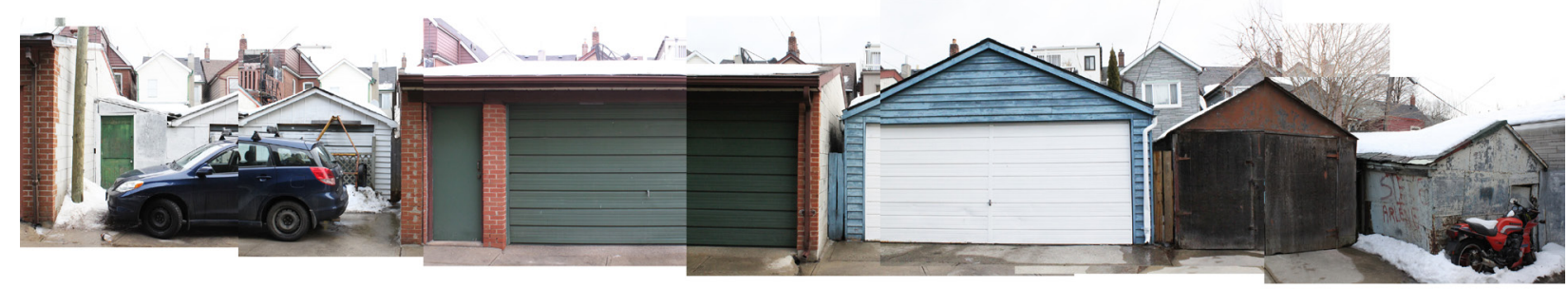

Figure 4-05 Site One Existing Lane Context.

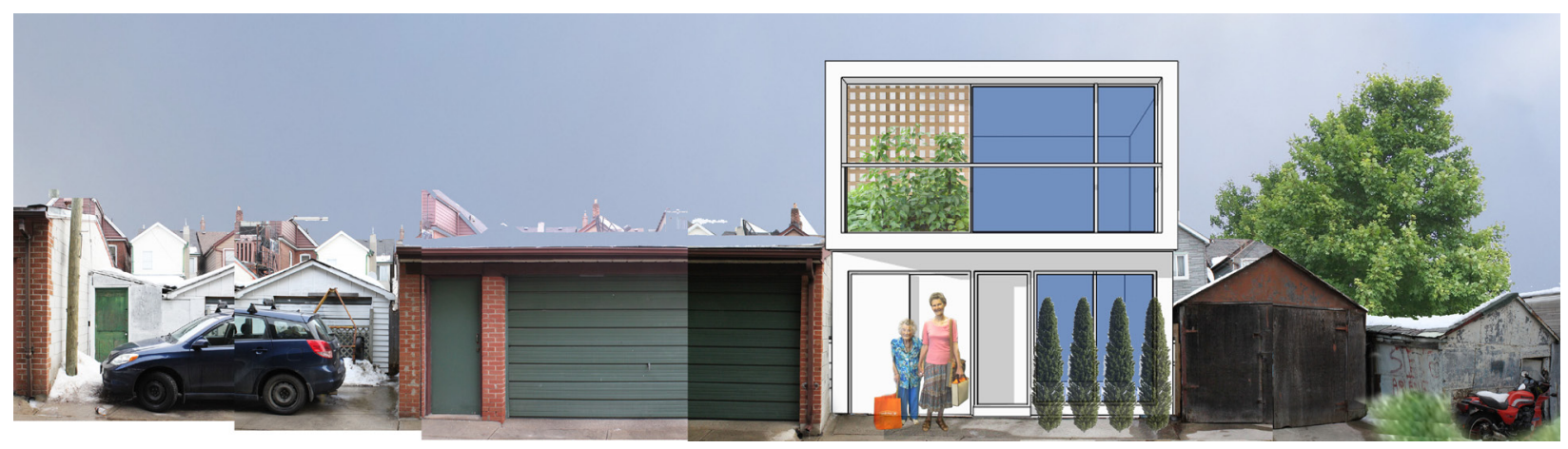

Figure 4-06 Site One Proposed Lane Context. 


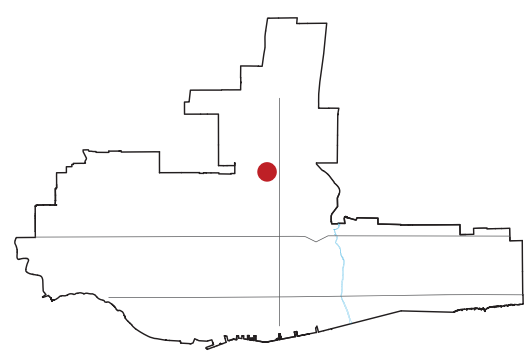

User Group

Young Family

Scenario: Small family looking to live in a detached house in the city, in an established neighbourhood with amenities within a walkable distance.

Working Couple

Scenario: Require a modest home, in a vibrant neighbourhood close to all amenities in which they can set up an at home office.

\section{Site Two - The Family Home and The Live/Work Home}

This second site is located in the north-central part of Old Toronto, in a historic neighbourhood containing larger lot depths and widths. Two neighbouring laneway house scenarios were tested on this block. Both houses were envisioned as being owned by the tenants, therefore required parking. The family home, being located on a wider lot, contains a drive in parking spot for the laneway house, as well as maintaining two parking spots for the principal dwelling.
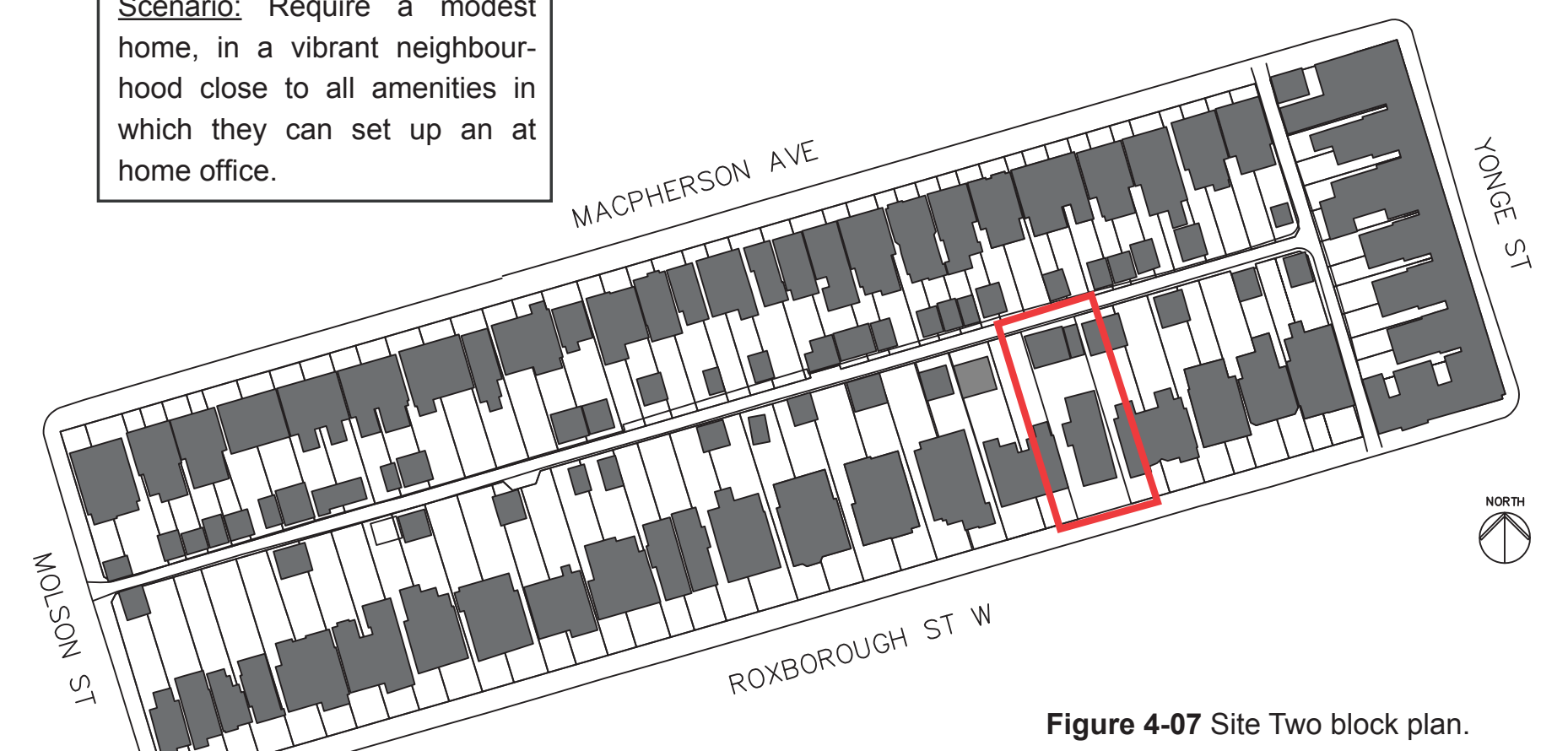

Figure 4-07 Site Two block plan.

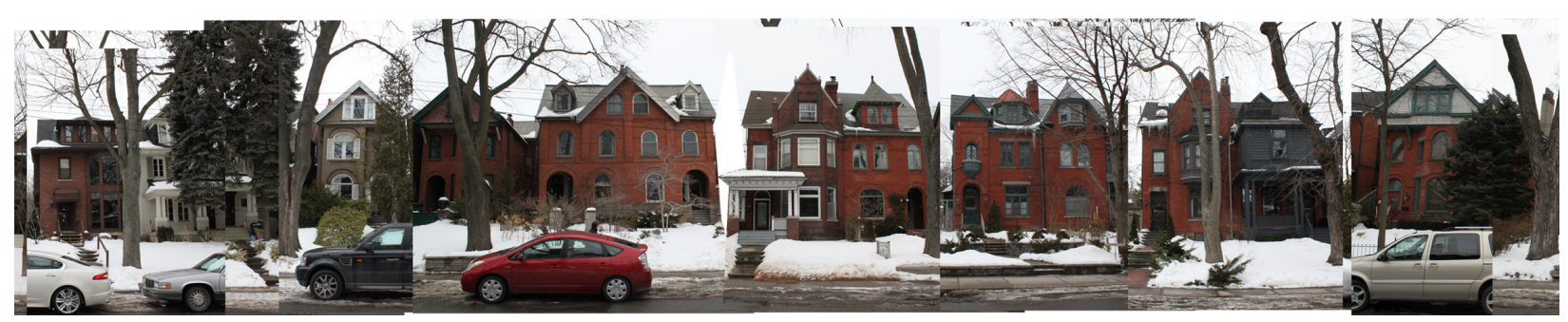

Figure 4-08 Roxborough Street - existing street fronting residential context. 

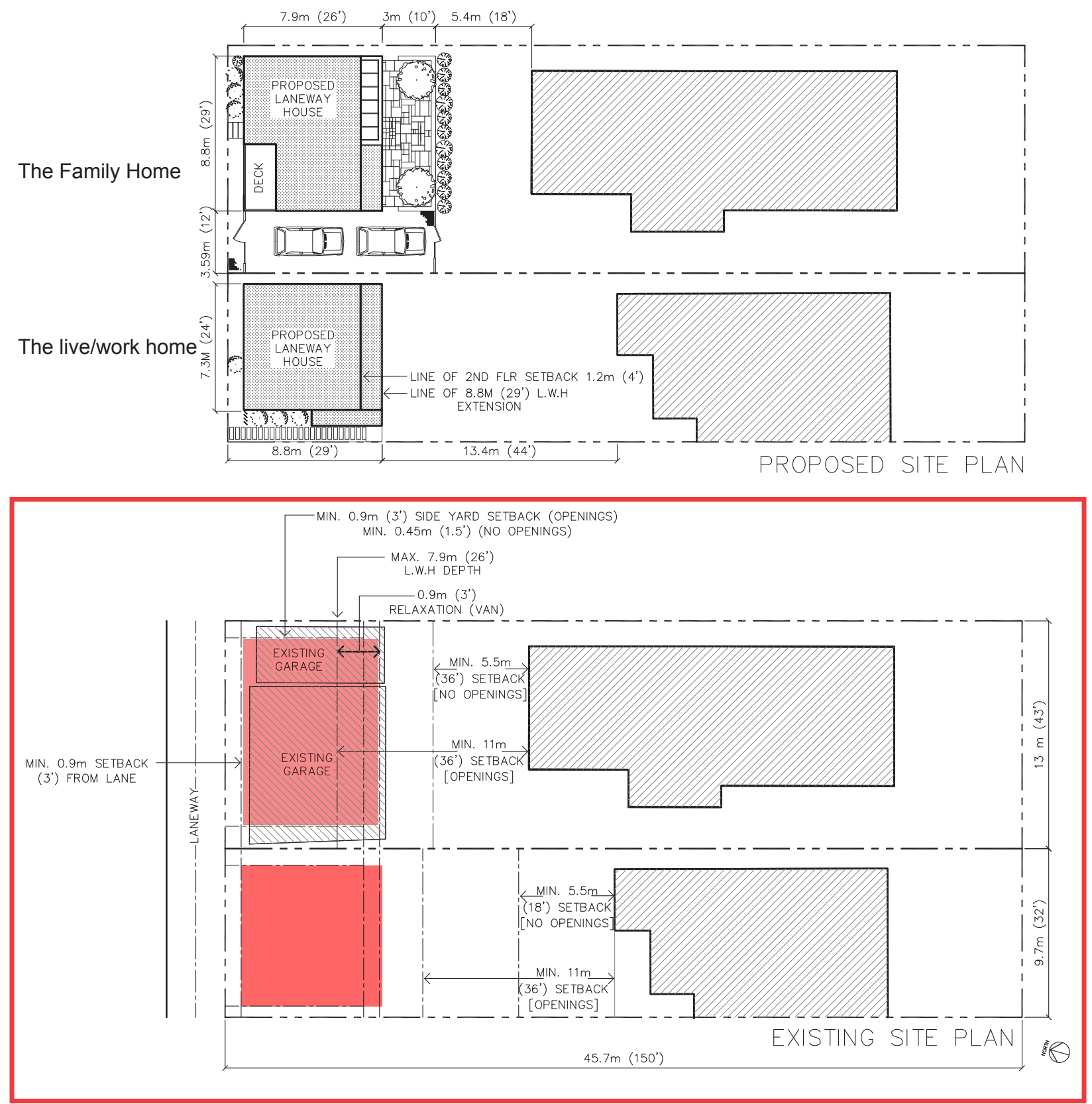

Figure 4-09 Site Two site plans. 


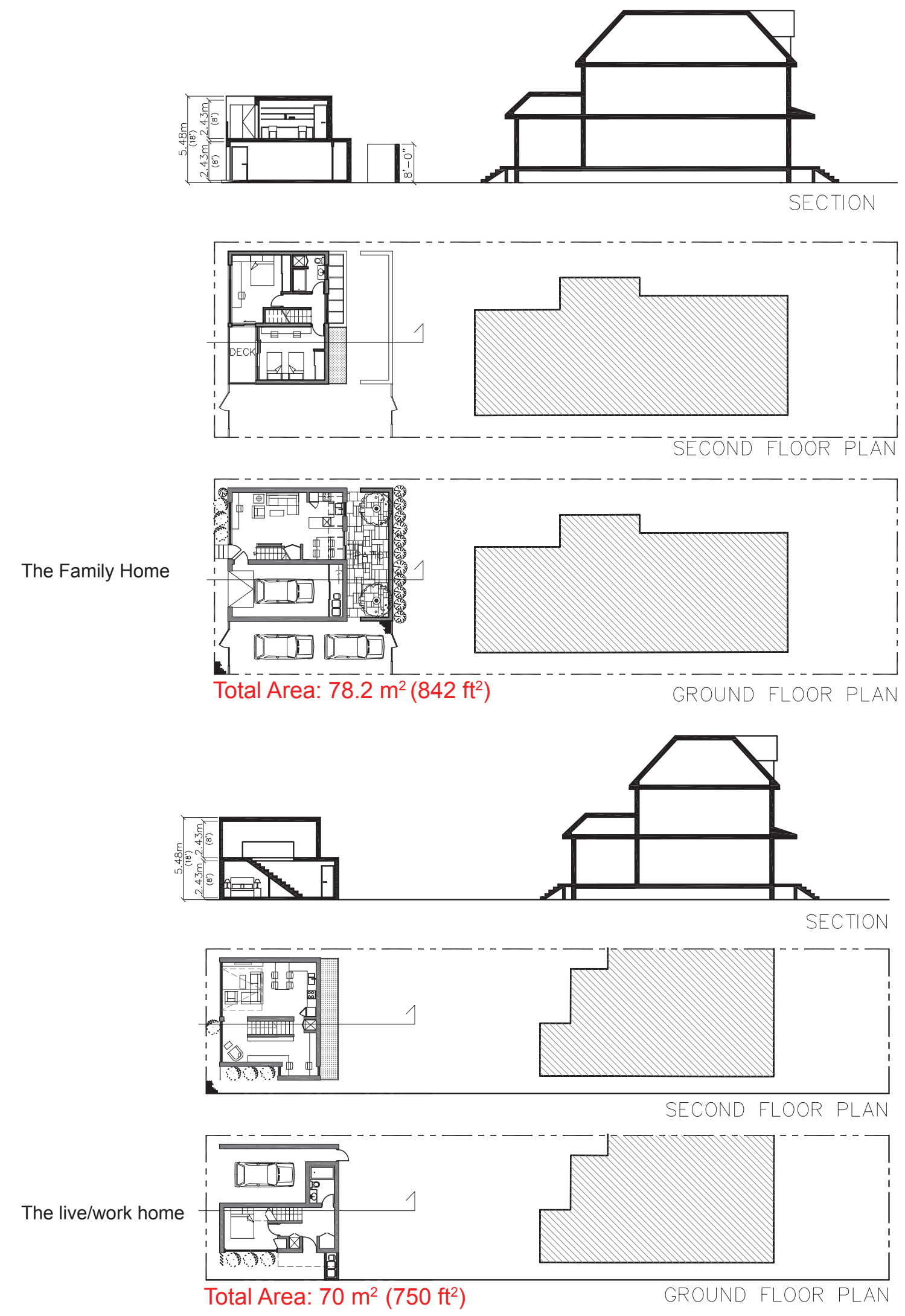

Figure 4-10 Site Two building plans and sections. 


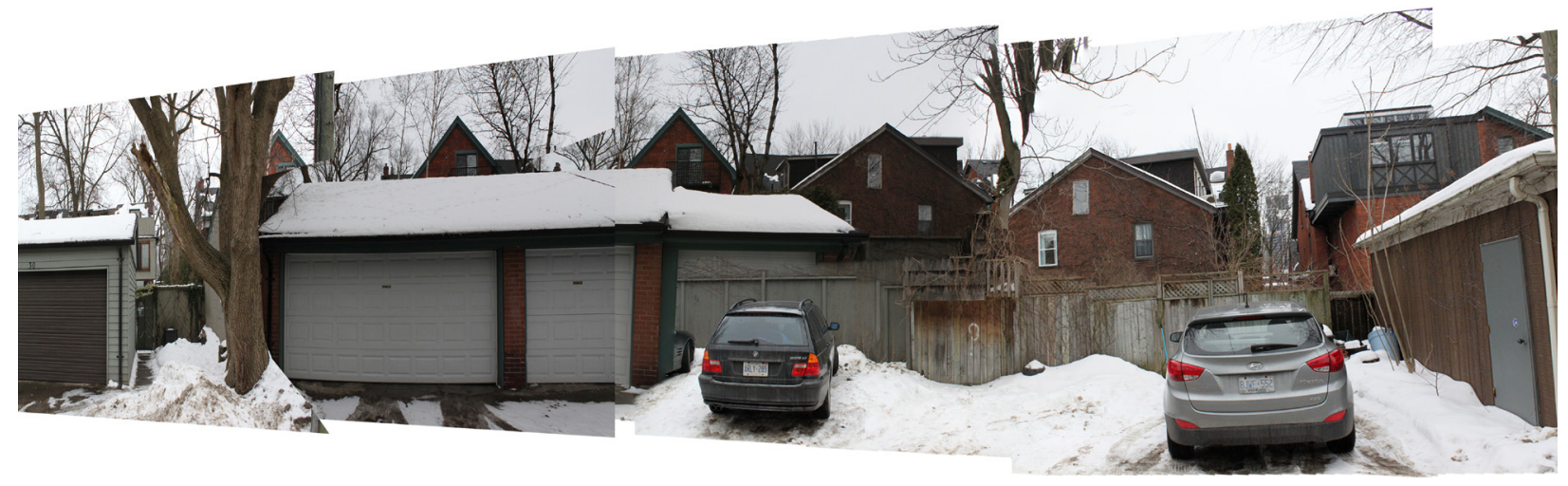

Figure 4-11 Site Two existing lane context.

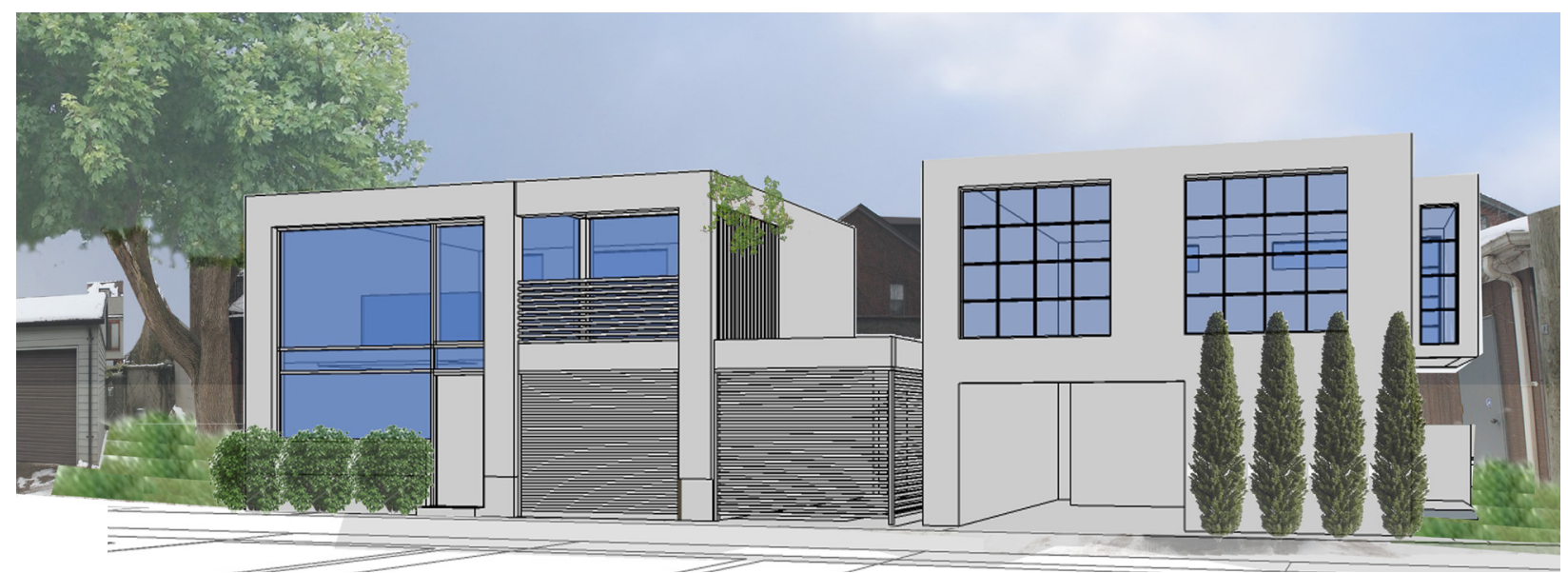

Figure 4-12 Site Two proposed lane context. 


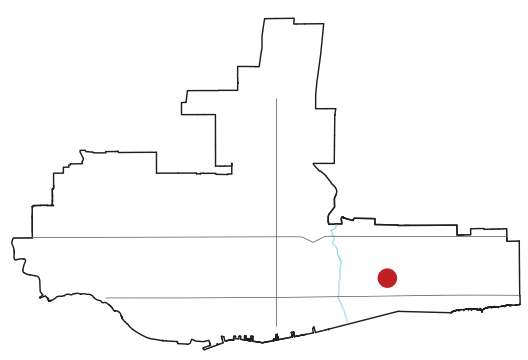

\section{User Group}

Young Family

Scenario: Small family looking to live in a detached house in the City, in an established neighbourhood with amenities within a walkable distance.

Single Parent

Scenerio: Requires a modest sized house in an established neighbourhood close to all amenities.
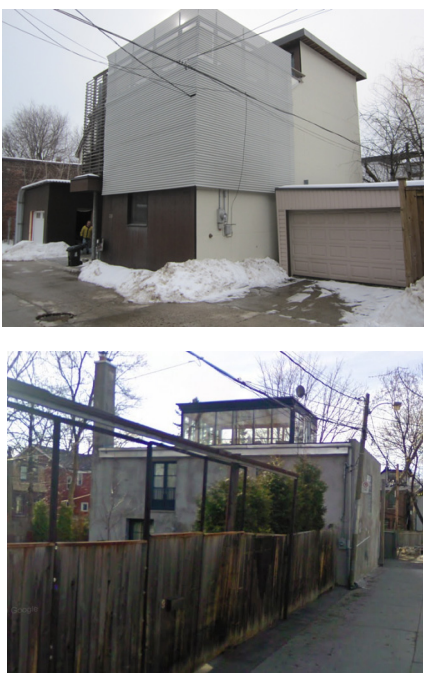

Figures 4-13, 4-14 Existing laneway houses.

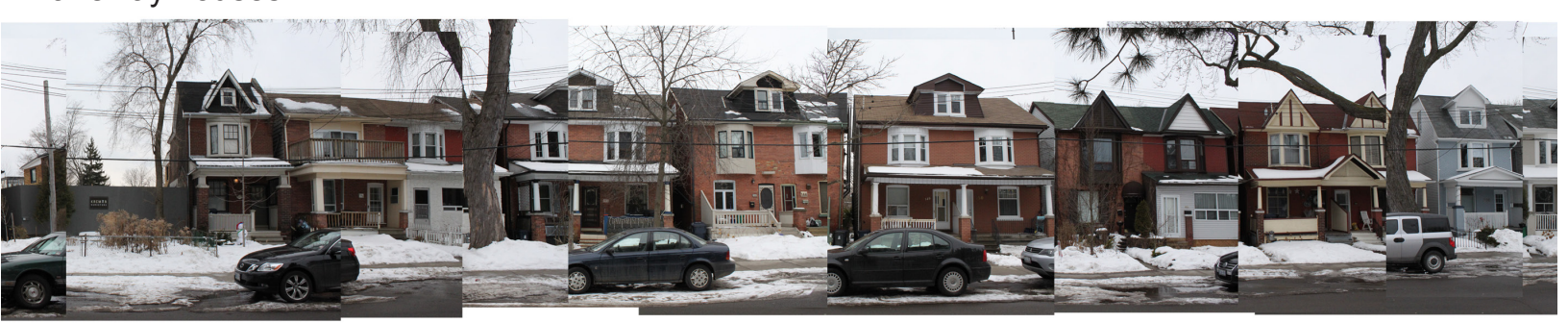

Figure 4-16 Curzon Street - existing street front residential context.

\section{Site Three - The Townhouse (Row house)}

This third site is located in the eastern part of Old (Pre-amalgamated Toronto) in an up and coming established residential neighbourhood. The block already contains two existing laneway houses. The site for the proposed laneway townhouses or rowhouses currently contains parking infrastructure. This site is presently up for a by-law amendment to allow for the construction of laneway rowhouses (see figure 2-31).

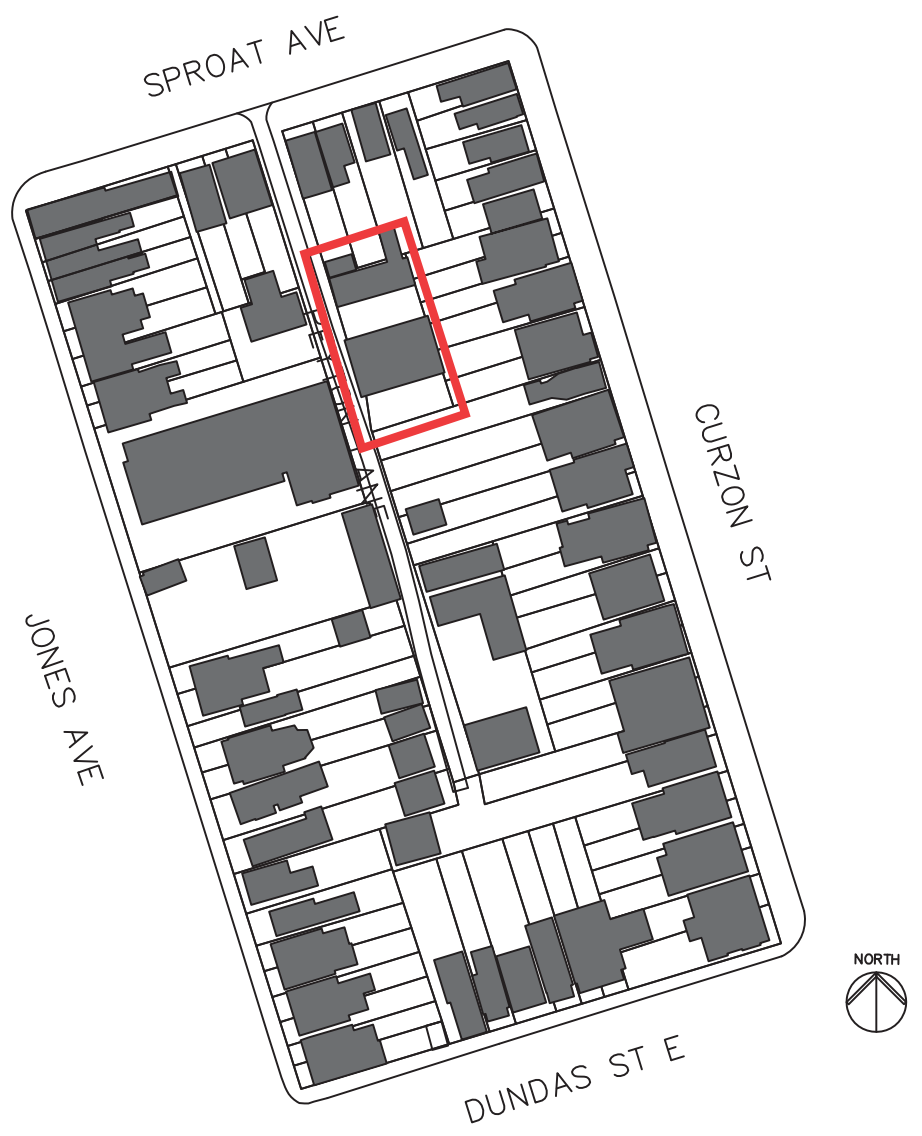

Figure 4-15 Site Three block plan. 

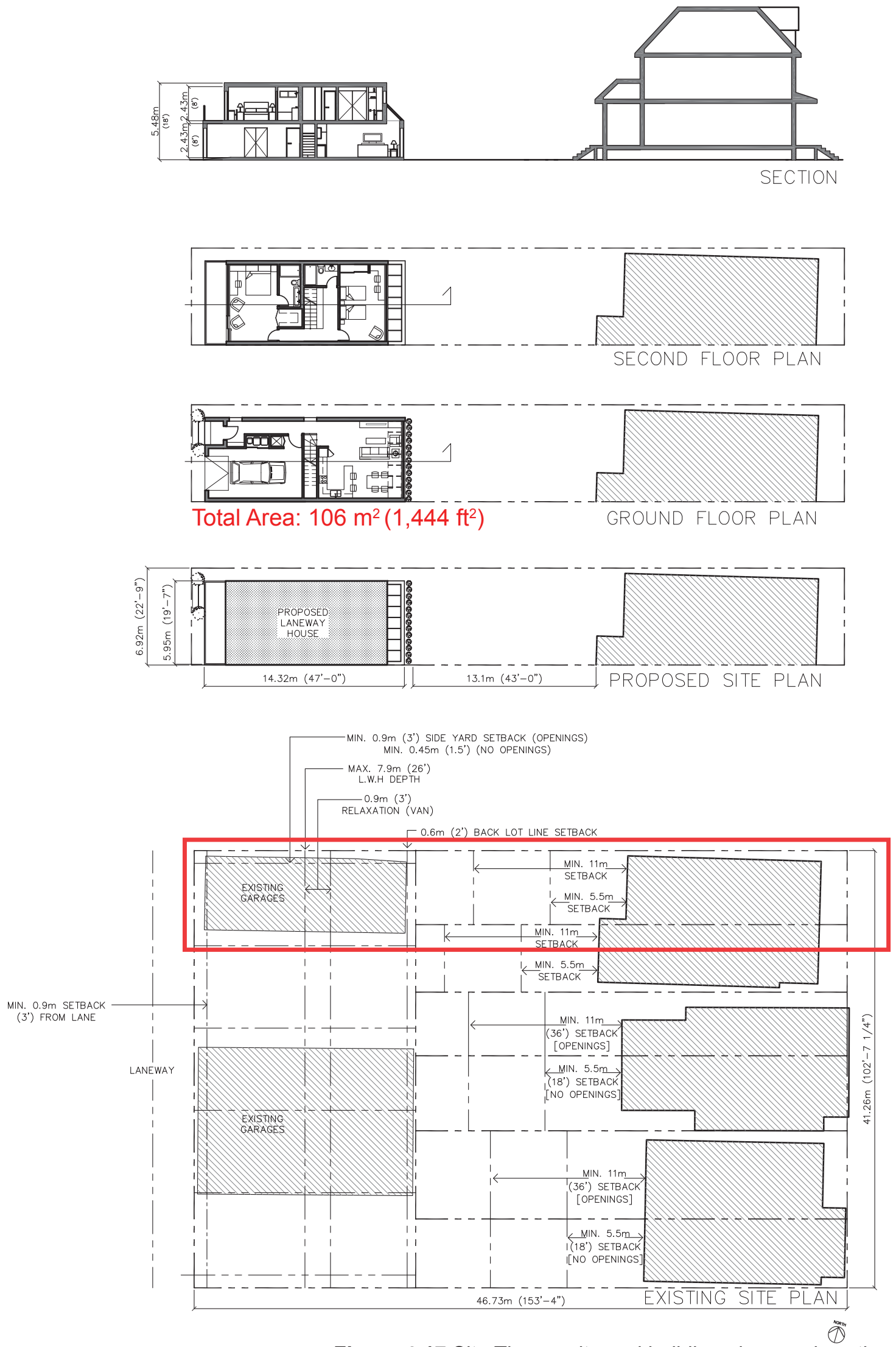

Figure 4-17 Site Three - site and building plans and section. 


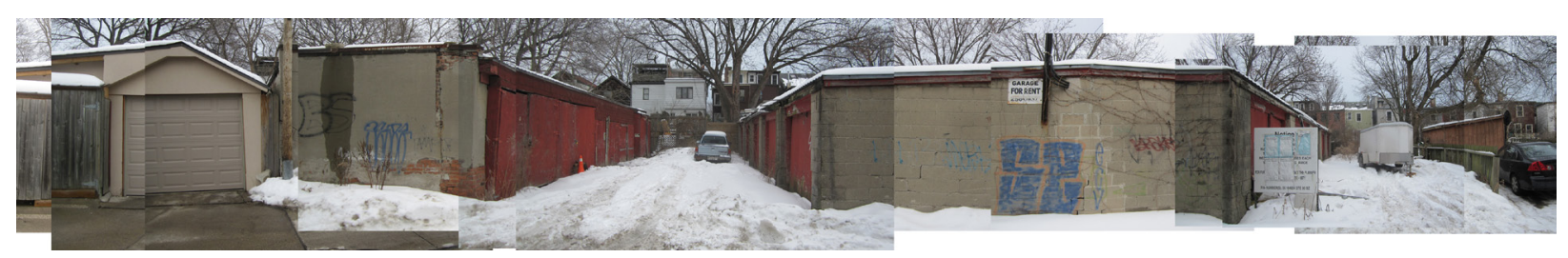

Figure 4-18 Site Three existing lane context.

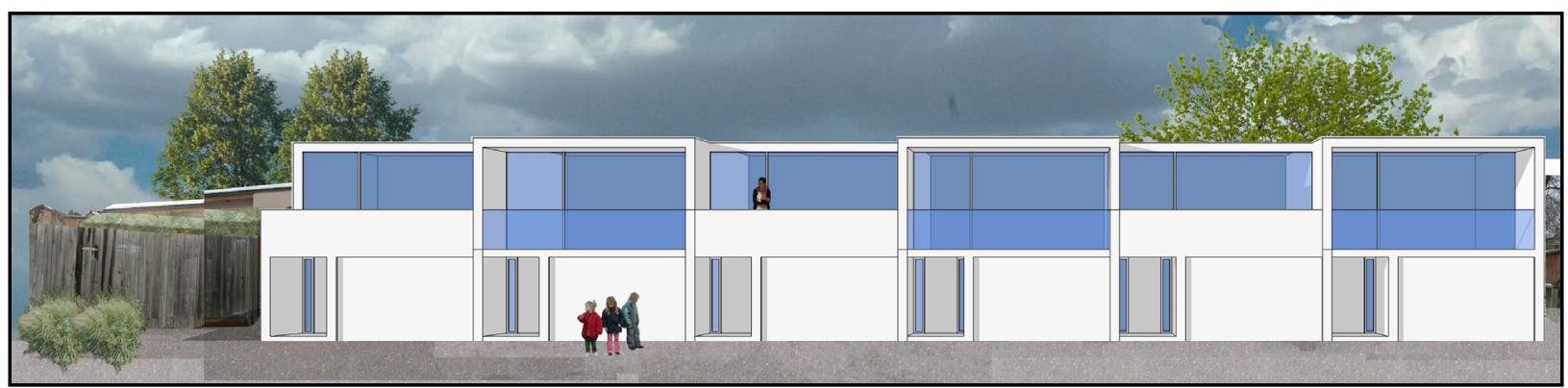

Figure 4-19 Site Three proposed lane context. 


\section{Summary}

The realized conclusions from the design explorations are two fold. Firstly, they confirm the findings in A.S.L.H.T. (Stinson \& Van Elslander, 2003) that the laneway housing typology can be supported by the City of Toronto's urban form. Even though some of the lot sizes are significantly restrictive, it is possible to design the laneway housing in a way that minimizes the 'adverse affects' associated with this typology and achieve considerably sized, well located, quality infill housing on Toronto's laneways. Many people live in apartments and condominiums of equal or lesser size than the aforementioned laneway houses in order to stay in the city. The laneway housing typology provides the opportunity of location and relationship to the street.

Conversely, through the process of placing all the test laneway houses from each site study onto a singular laneway in order to observe the potential emergent form of a residential lane-scape, it was realized that the proposed laneway housing form and its placement on the lot, created linear and constrictive results on the lane-scape. Concern for the laneway house's spatial restrictions and attempt to be subordinate in relationship to the principal dwelling and surrounding context, has resulted in an uninteresting and un-welcoming lane-scape due to the emergent laneway housing forms. With laneway housing facades built right up to the lane property lines, and all open space located in the back, or on the roof, the laneway housing program has been internalized, barricading itself from the principal dwelling and the laneway.

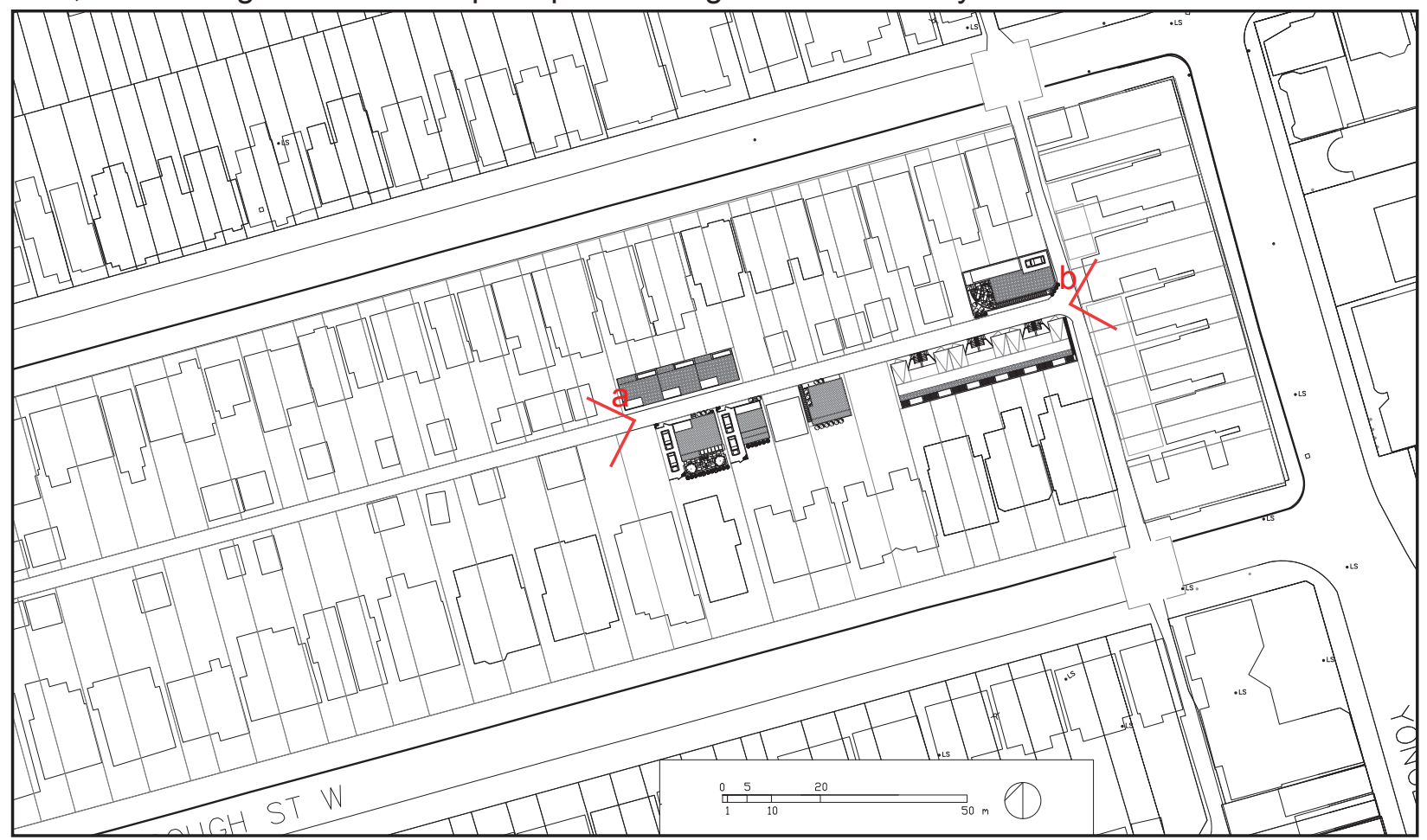

Figure 4-20 Site Two block plan containing all L.W.H. prototypes. 


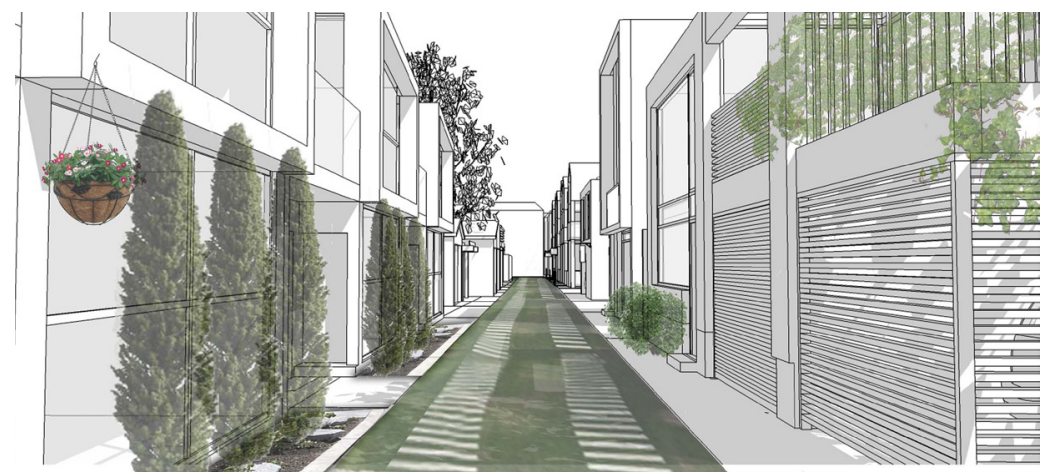

Figure 4-21 (a) Laneway view one.

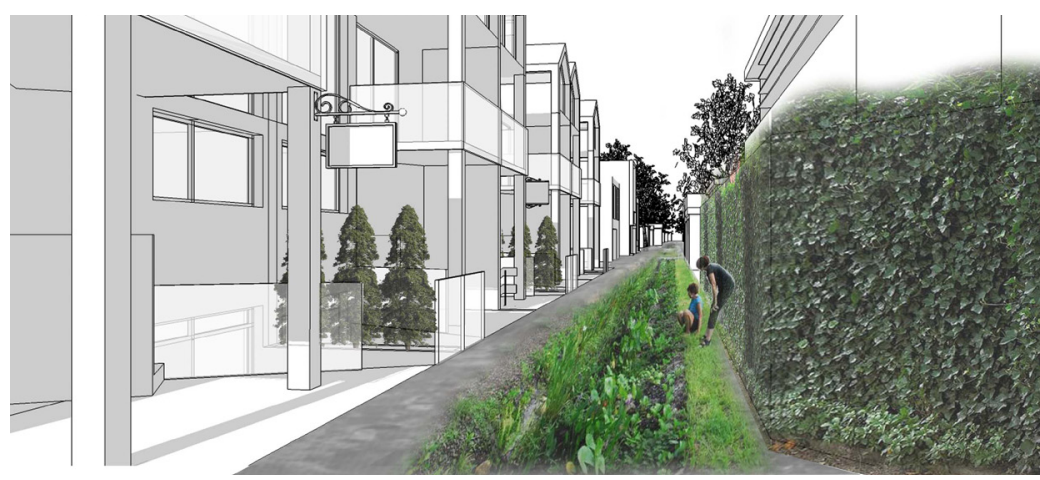

Figure 4-22 (b) Laneway view two.

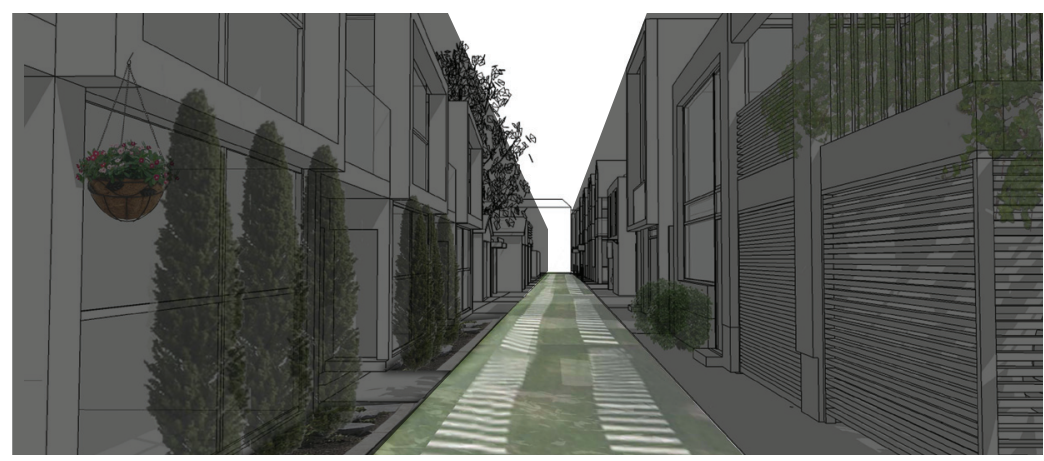

Figure 4-23 (a) Narrow and constrictive lane-scape resulting from laneway housing form and lane setbacks.

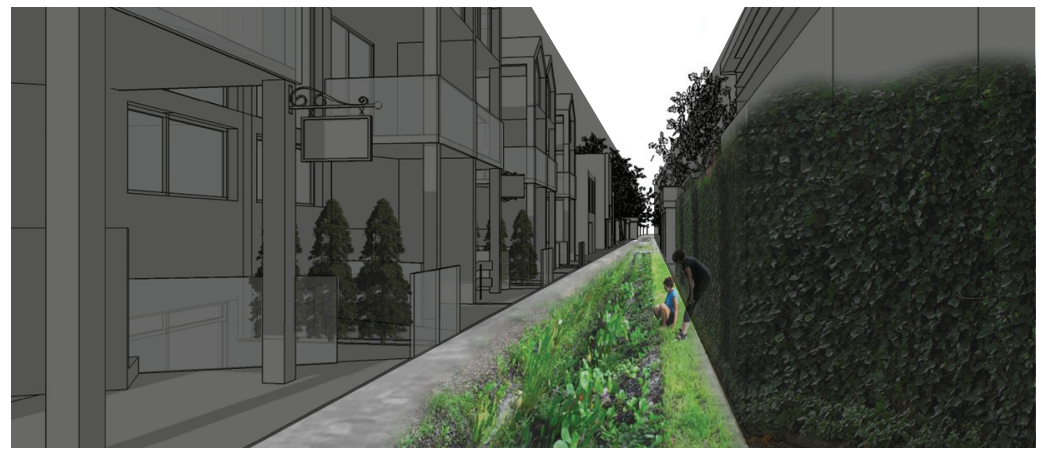

Figure 4-24 (b) Narrow and constrictive lane-scape resulting from laneway housing form and lane setbacks.
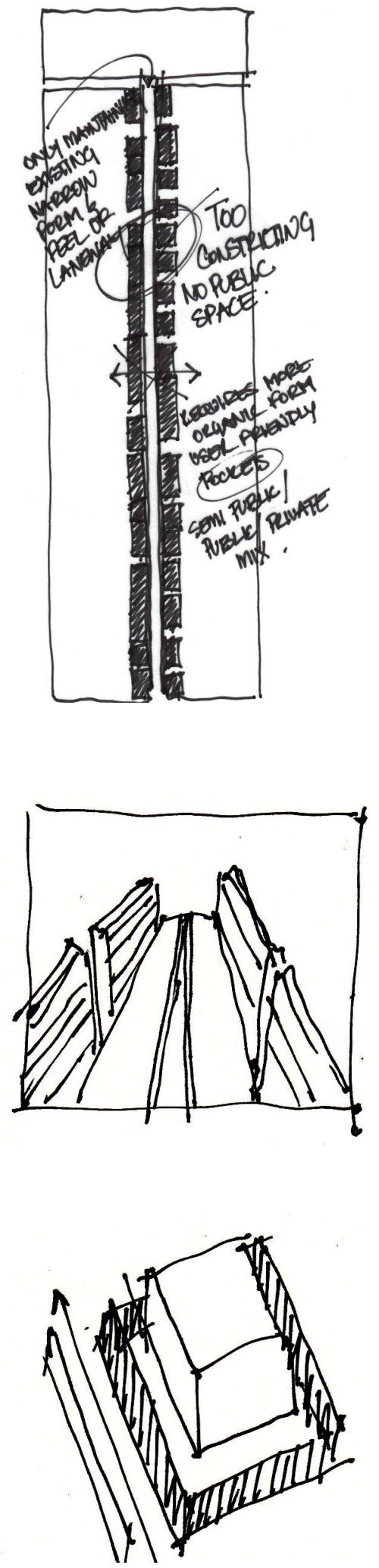
3. explore. 


\section{Explore - Evolution and Organic Growth}

The following design exploration was born out of the conclusions and realizations of the previous two intentions. It's goal is to explore the laneway housing form, not on a lot by lot basis, but its evolution in the entire laneway context, arguing that when designed from this perspective, the laneway housing form has the potential to foster the growth of strong and desirable mid-block communities.

Site two will be used for the purpose of this design exploration (see figure 4-02). The lot depths reflect the average lots depths and the City of Toronto and the widths and principal dwelling setbacks vary, providing for interesting building form responses. The block is located in an affluent part of the City of Toronto, with varying residential building typologies. The block abuts one of the main arterial commercial corridors of Yonge Street, with access to numerous amenities, and public transit.

This block is seen as an opportune choice to envision the construction of a desirable laneway community. With ground related housing prices in this area being very high, the development of laneway housing could provide a much desired and more affordable ground related housing typology in this neighbourhood.
Design Considerations

- Maintain established setbacks (increase lane setback to min. $1.5 \mathrm{~m}$ (5').

- Maintain established height restrictions.

- Maintain open space and privacy requirements.

- L.W.H. lot options: severed; severed and consolidated.

- Consolidate services (garbage, mail) and maintain considerations for emergency vehicle access.

- Remove parking requirement and provide consolidated autoshare option.

- L.W.H. building form to engage laneway.

- L.W.H. open space to be brought to the front of house.

- Preserve existing trees.

- Design varying housing typologies to reflect the needs of different laneway housing user groups.

- Incorporate laneway improvement, woonerf, and community greens principles to create a relationship between the laneway dwellings and the lane-scape. 


\section{A Comment on Existing Laneway Housing Form}
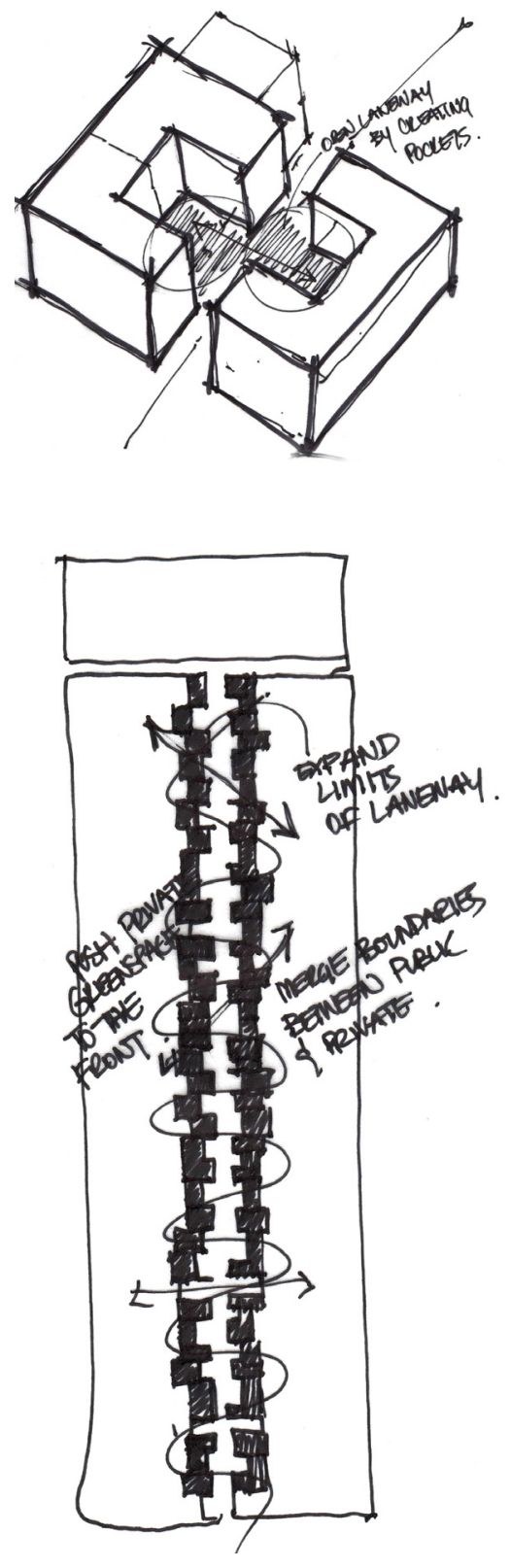

Existing laneway housing form resembles fortresses on the laneway. They appear defensive, as if trying to disguise themselves, so no one notices their existence and therefore have no relationship to the laneway. This is a response to the predisposition of this type of building typology in Toronto, however, in order for laneway housing to be accepted as a legitimate housing typology in the city, the negative predispositions must be dismissed. As a result, "the laneway dwelling should not appear to be a fortress, or of secondary nature" (Stinson \& Van Elslander, 2003, phase two), instead architectural design considerations must promote the functionality and desirability of these buildings so that the "negative association of the 'back alley' can be improved by the construction of laneway dwellings" (Stinson \& Van Elslander, 2003, phase two).

The facing page shows four revered existing Toronto laneway houses. Each house was designed by a highly respected Toronto architectural firm. These laneway houses are a prime example of how extremely functional and desirable residential spaces can be designed on Toronto's laneway lots. They exemplify architectural precision in interior spatial configurations, designing for natural daylighting and open space. However, all four of these houses (some more than others) also reflect a very internalized and defensive architectural form. Most likely as a response to the urban form constrictions and issues of privacy, these houses seem to hide from the laneway.

This exploration argues that the design of laneway dwellings should not be informed only by the 'adverse effects' associated with this building typology. The form of the laneway dwelling should be informed by its relationship to the laneway and the anticipation of adjacent laneway properties in order to, through building form, foster the growth of vibrant and desirable midblock communities. 

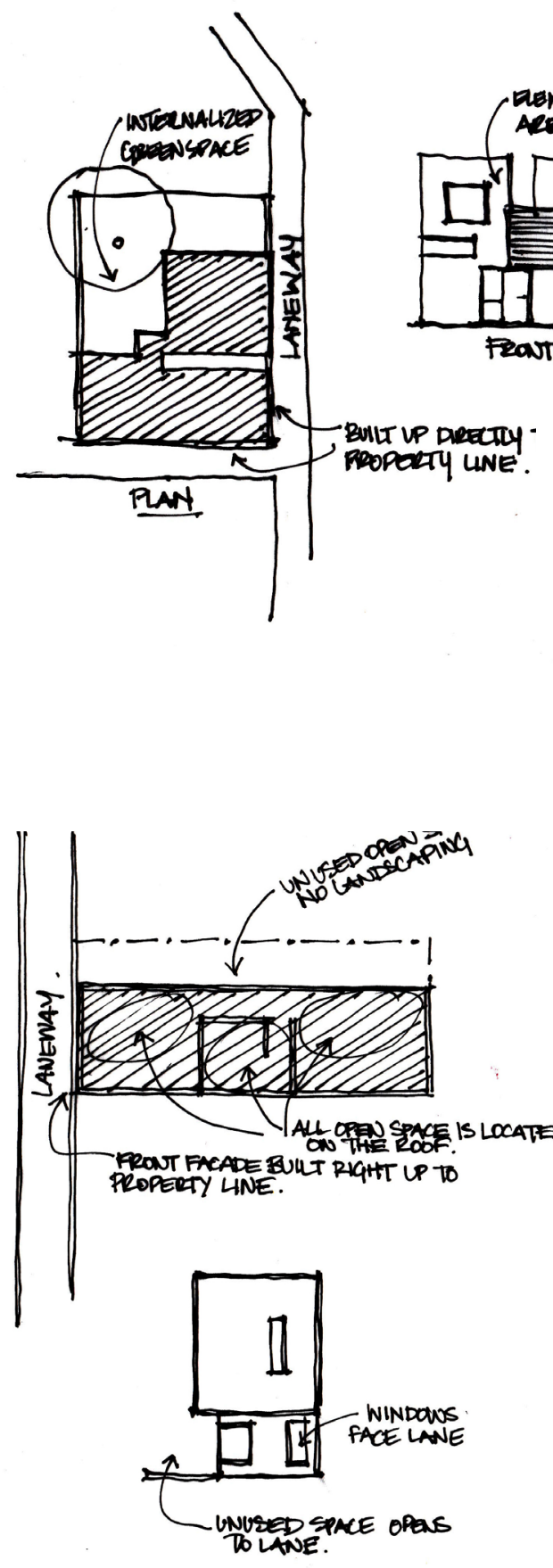

Figure 5-03 40R Shaftesbury by superkul inc Architect.

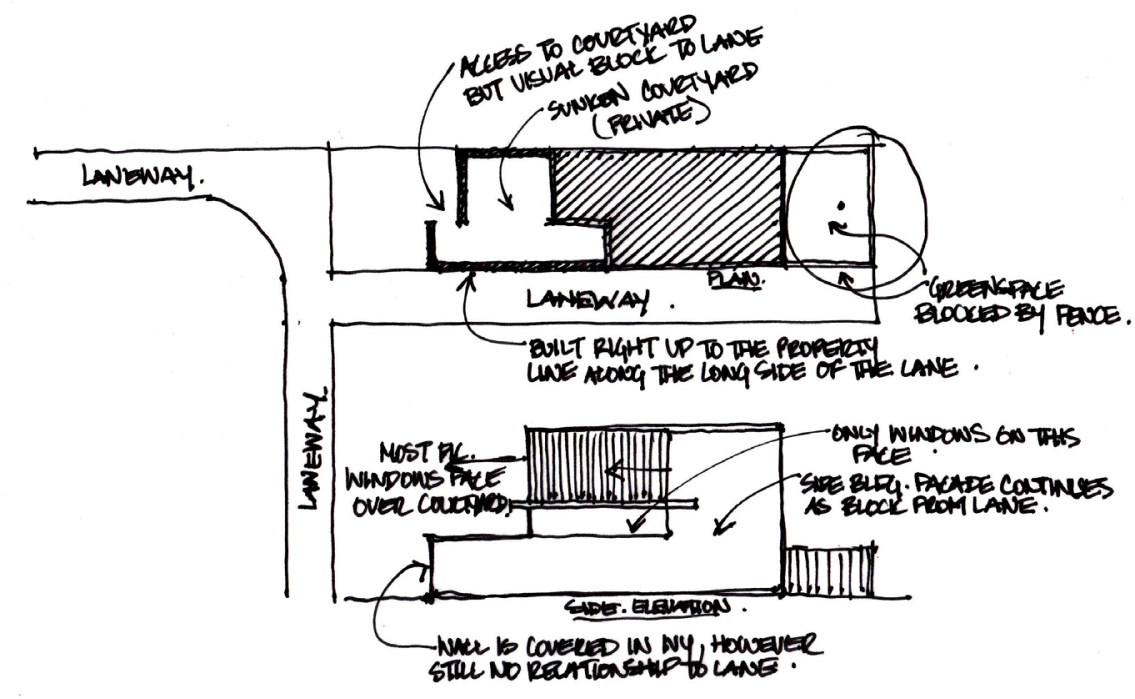

Figure 5-02 7 Leslie Garden Lane by Shim Sutcliffe Architects.

Figure 5-01 1 Ways Lane by Diamond and Schmitt Architects.

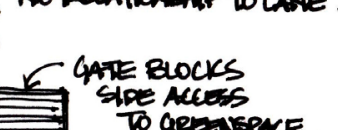

TO GPECNEPACE
(CARPARC)

Reyation. 
Site Typology Analysis

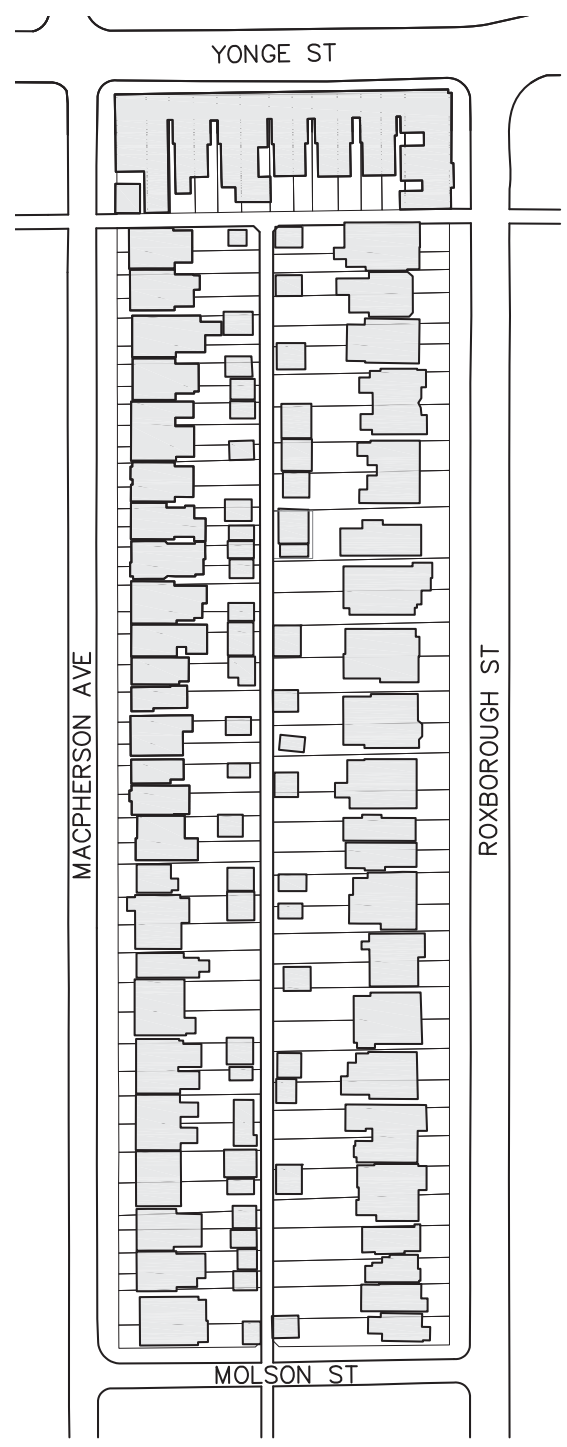

EXISTING BLOCK TYPOLOGY

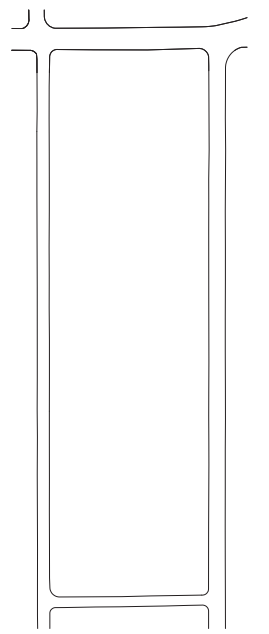

MAIN ROADS

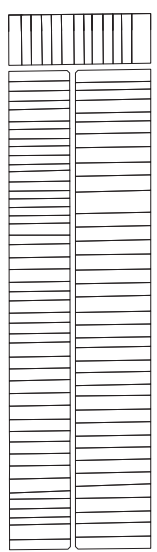

EXISTING PROPERTY LINES

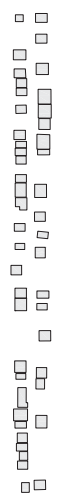

EXISTING GARAGES

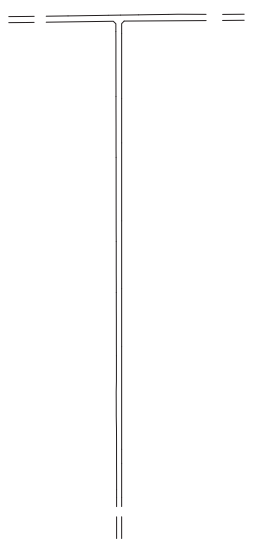

LANEWAY

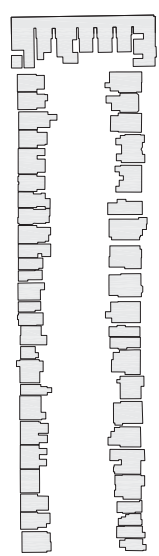

EXISTING BUILT FORM

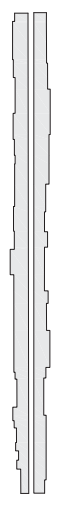

EXISTING PARKING DESIGNATION COVERAGE 
Site Typology Development

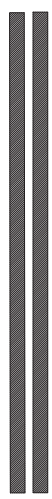

POTENTIAL L.W.H. COVERAGE $11 \mathrm{M}\left(26^{\prime}\right)$ MAX DEPTH EXTENT. (BASED ON VANCOUVER CRITERIA).

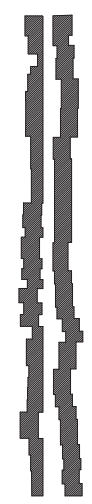

POTENTIAL L.W.H. COVERAGE BASED ON 11M (26') MAX DEPTH EXTENT \& 5.5M (18') P.D. SETBACK.

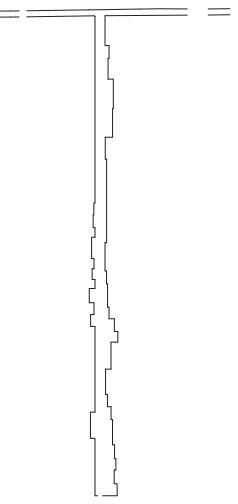

PROPOSED LANEWAY FORM

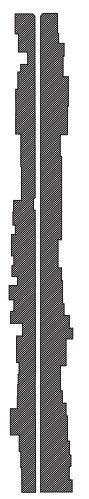

PROPOSED SITE PLAN AREA

POTENTIAL L.W.H. MAX COVERAGE 5.5M (18') P.D. SETBACK.

(BASED ON TORONTO ZONING CRITERIA).

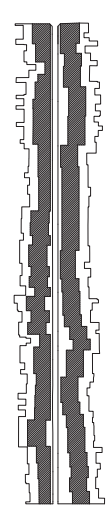

SITE STUDY BOUNDARY

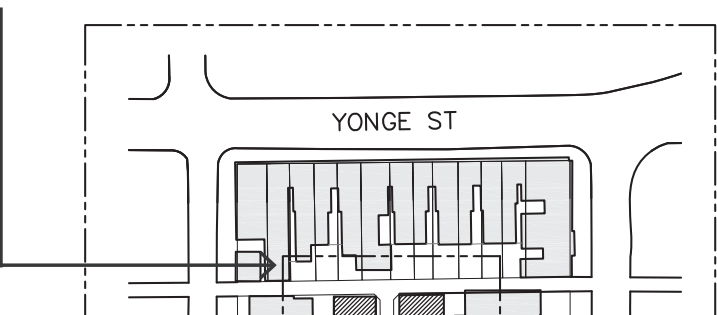

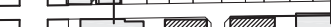
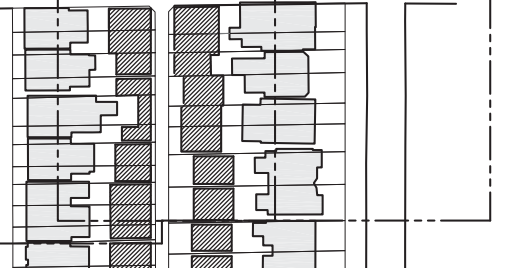

POTENTIAL L.W.H. COVERAGE BASED
ON $11 \mathrm{M}\left(26^{\prime}\right)$ MAX DEPTH EXTENT \& 5.5M ON 11M (26') MAX DEPTH EXT
(18') P.D. SETBACK

(SHOWING REMAINING P.D. OPEN

$$
\text { SPACE). }
$$
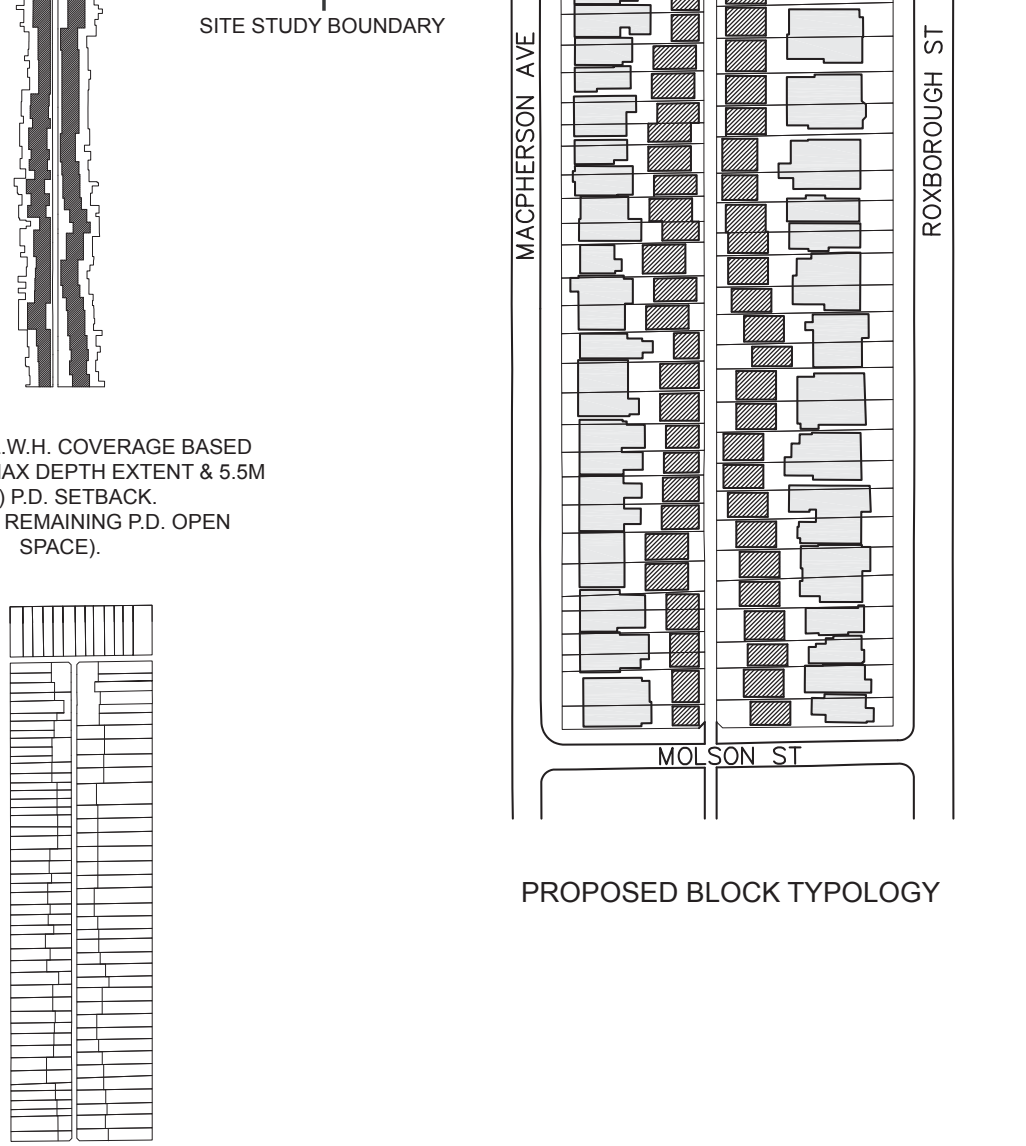

PROPOSED BLOCK TYPOLOGY

PROPOSED PROPERTY LINES 


\section{Site Form Development}

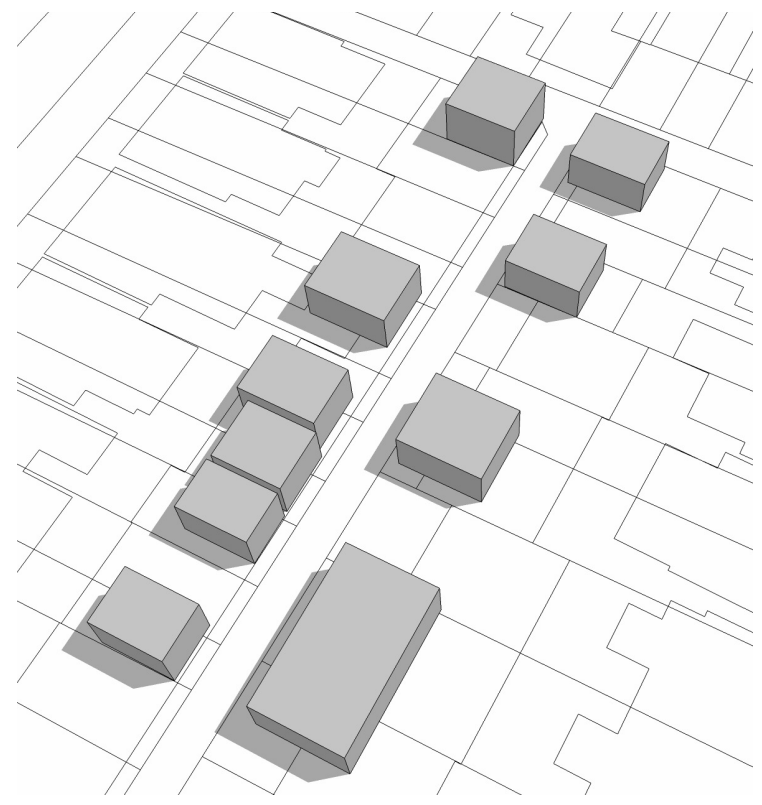

EXISTING GARAGE FORM

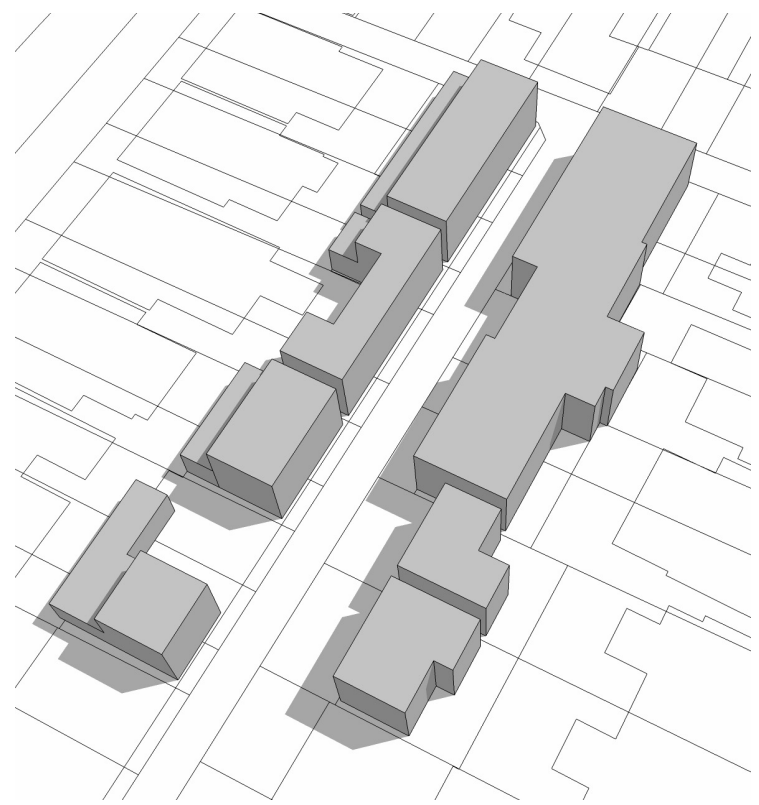

4. SECOND FLOOR CONTRACTION

(SHADOWING ON P.D.)

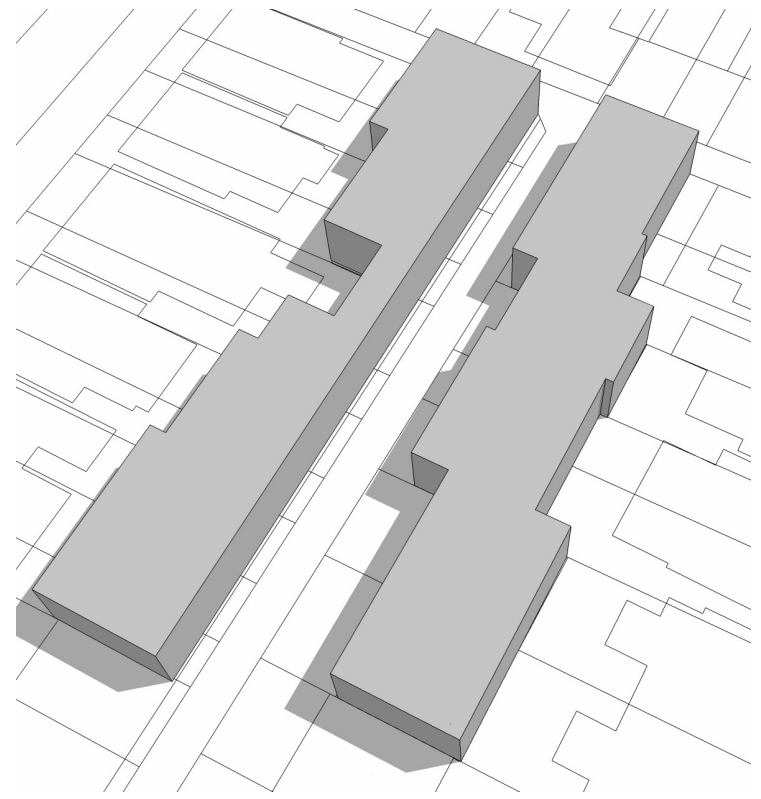

1. PROPOSED L.W.H. COVERAGE

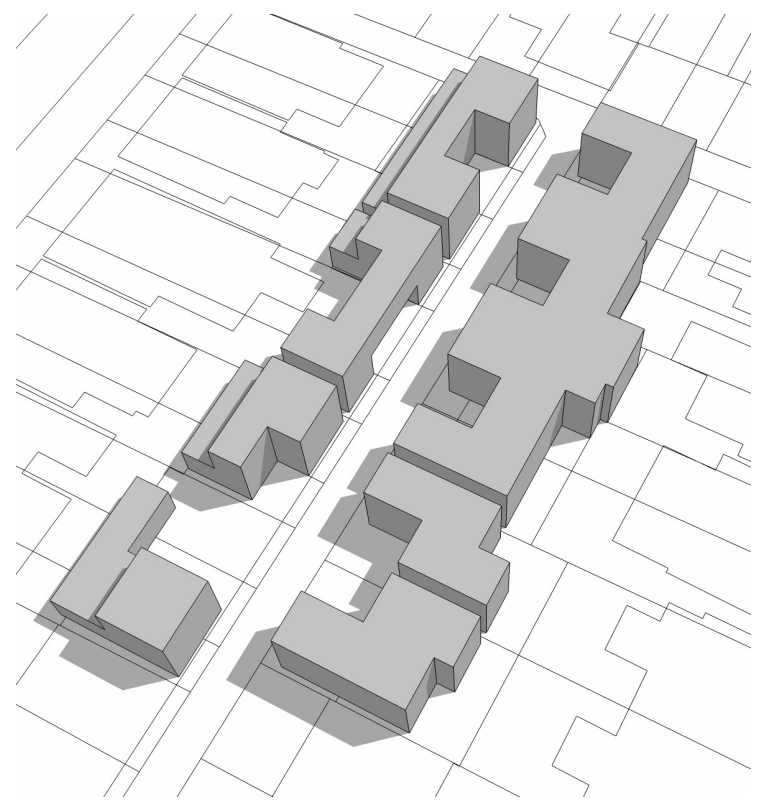

5. RELATIONSHIP TO LANE \& NEIGHBOURING L.W.H. CONTRACTION \& EXTRACTION 


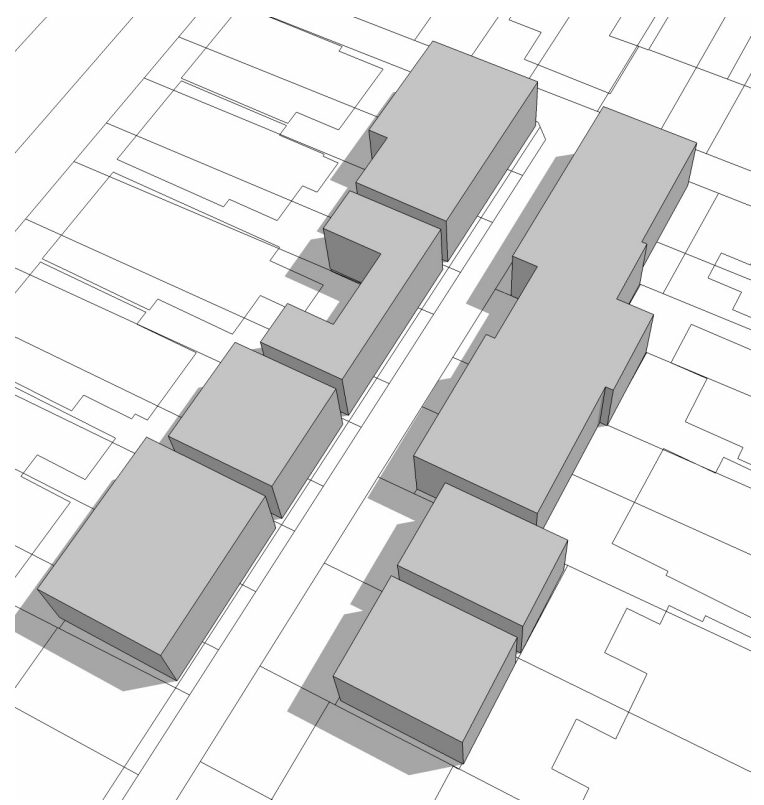

2. SIDE YARD SETBACK CONTRACTION

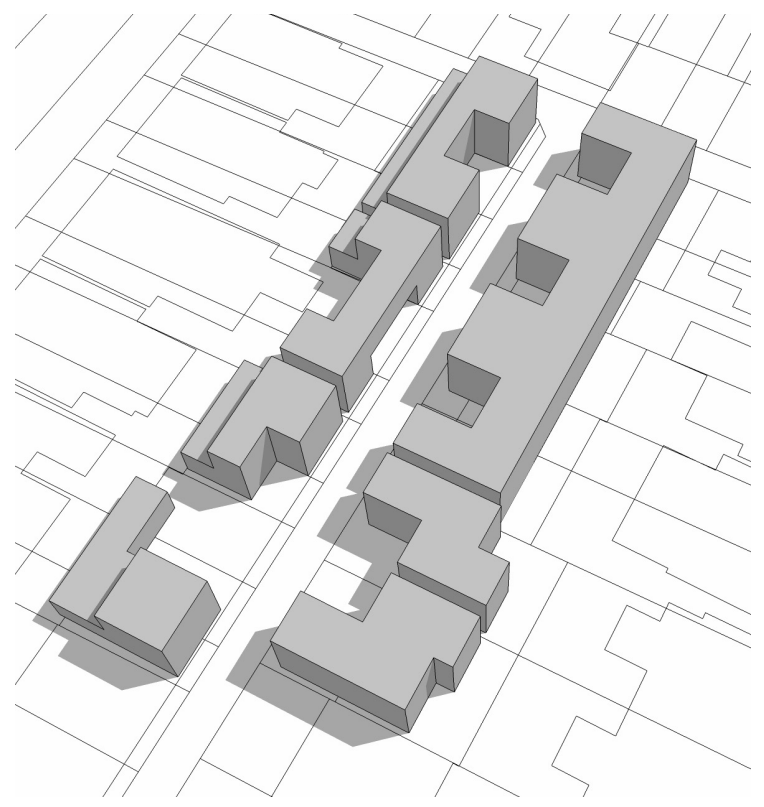

6. FORM CLEAN UP

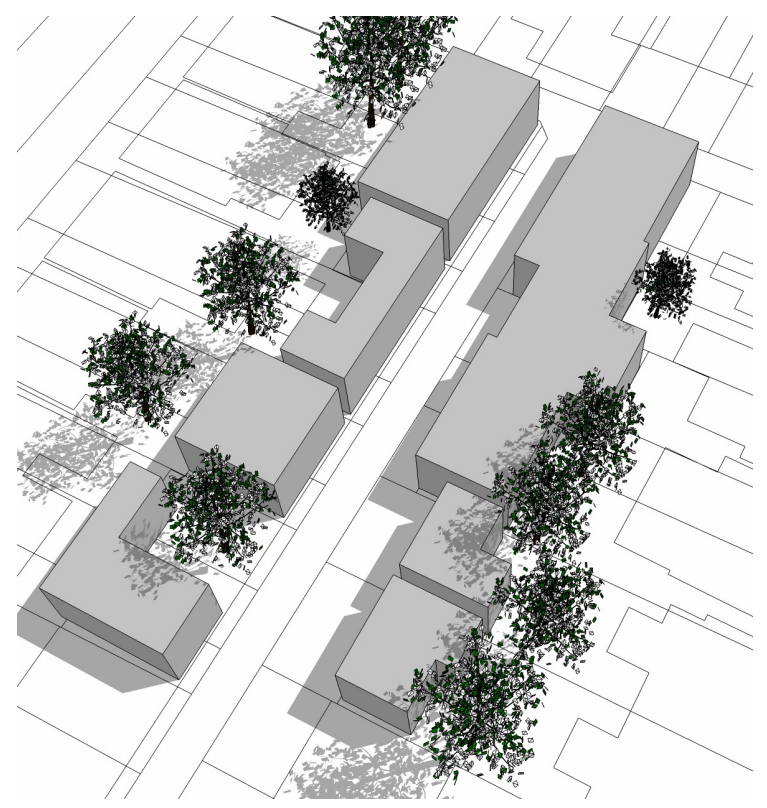

3. EXISTING TREE CONTRACTION

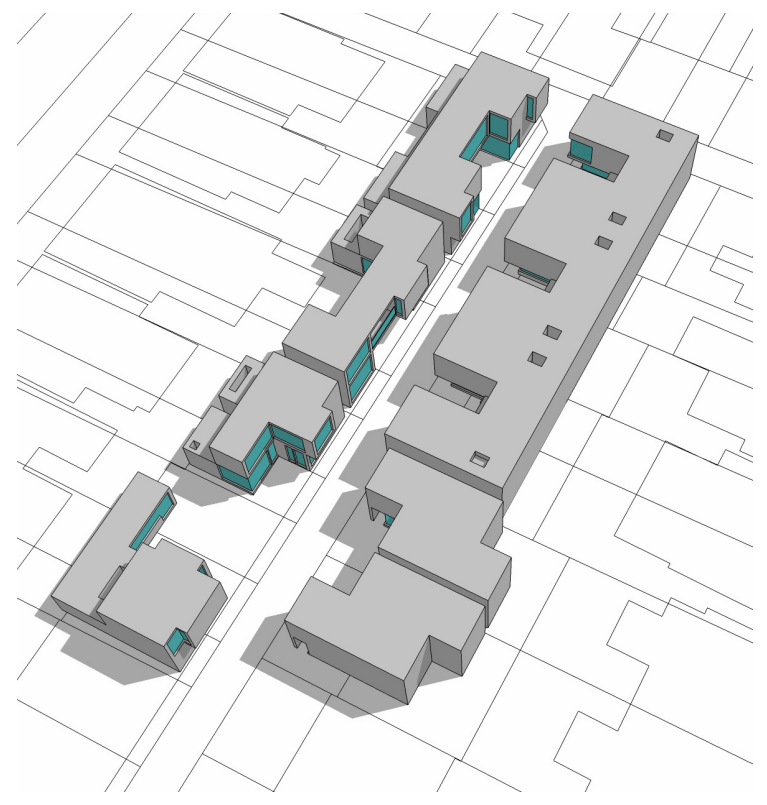

7. GLAZING 


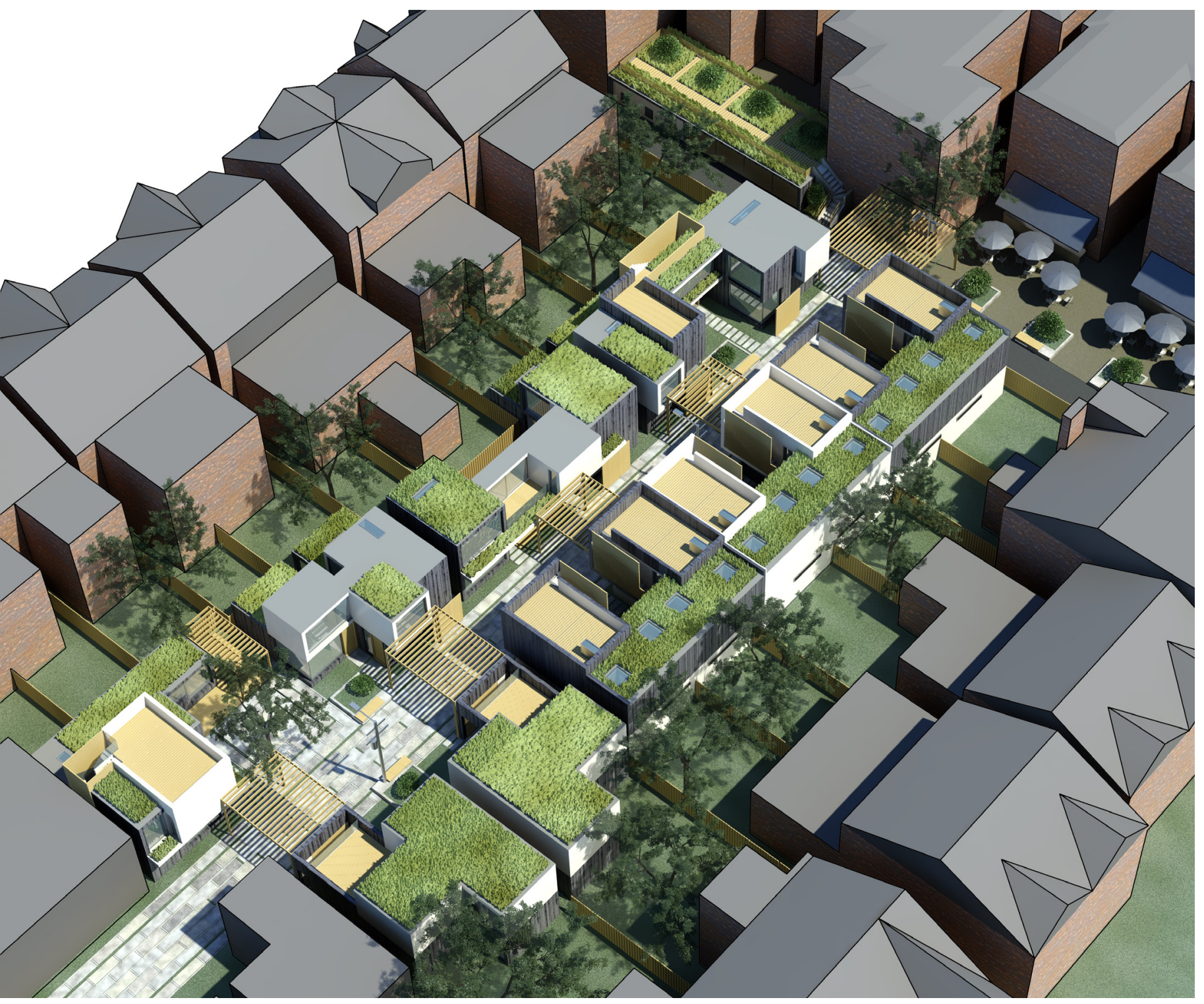

Figure 5-05 Final design manifestation. Aerial view looking North East. 


\section{Final Design Manifestation}

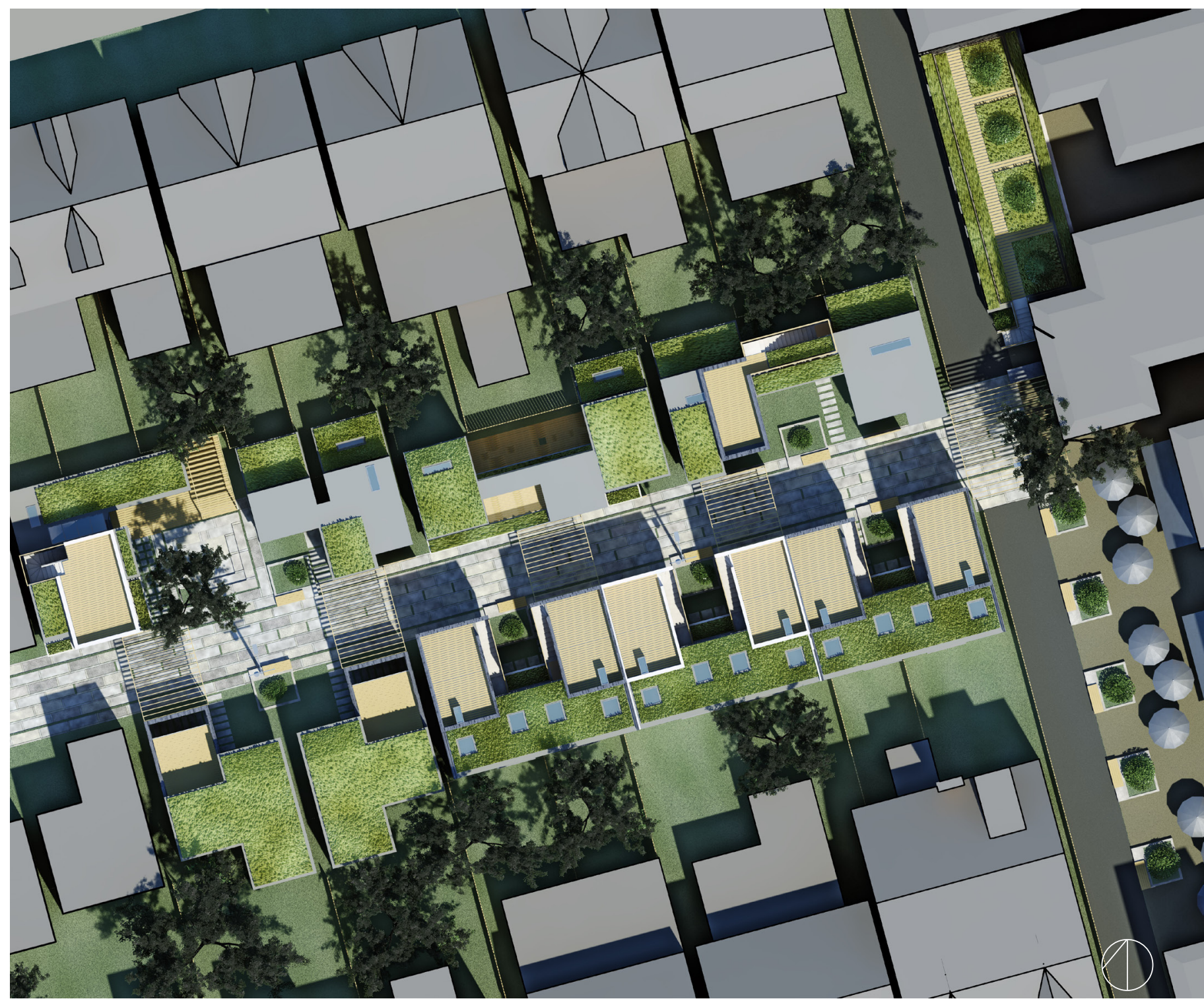

Figure 5-06 Final design manifestation. Proposed site plan. 

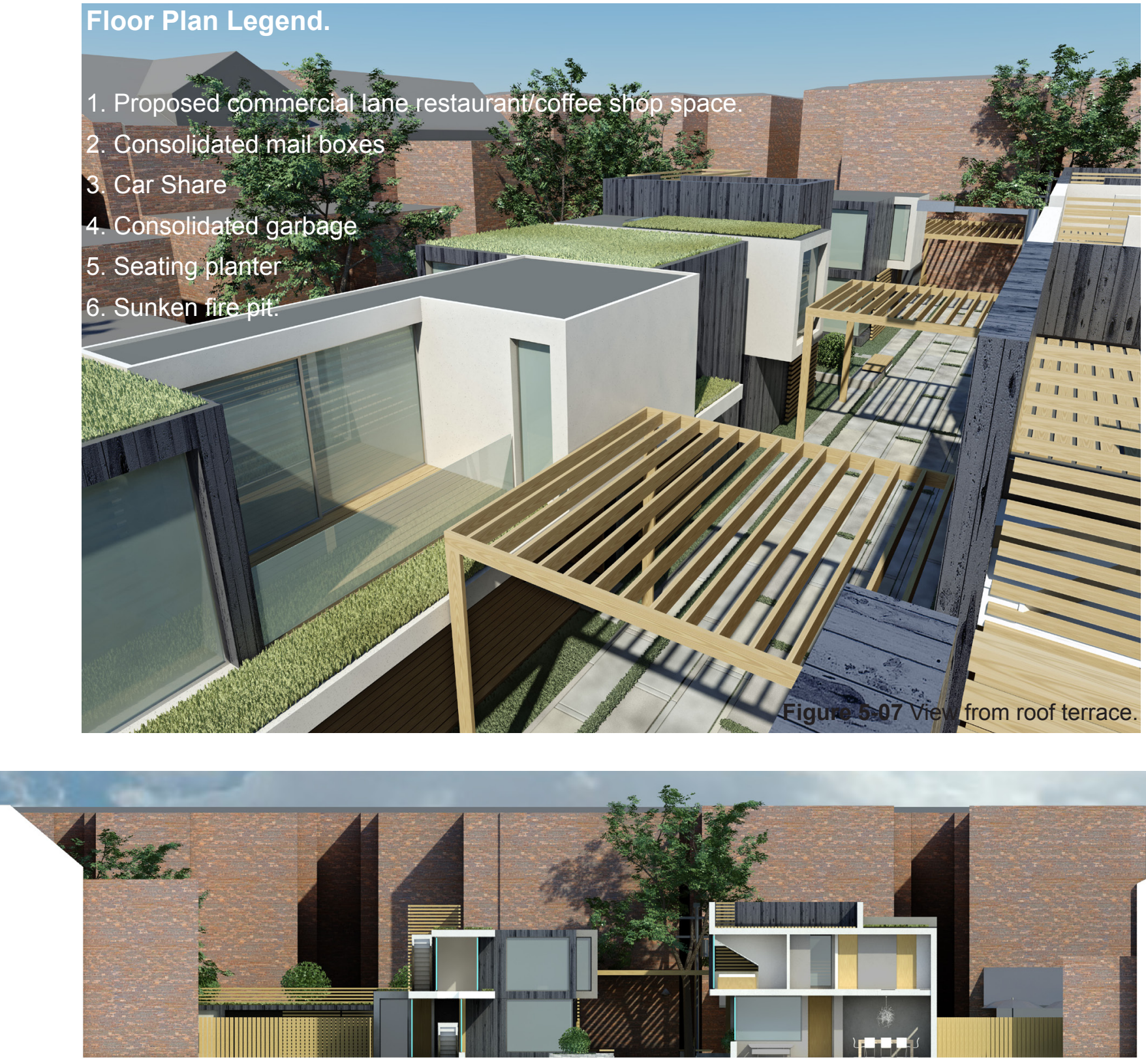

A: Section looking East.
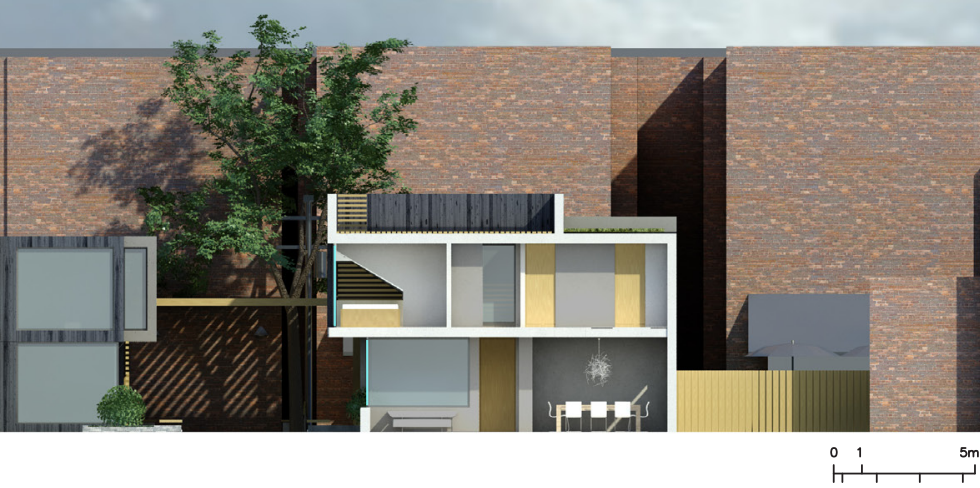

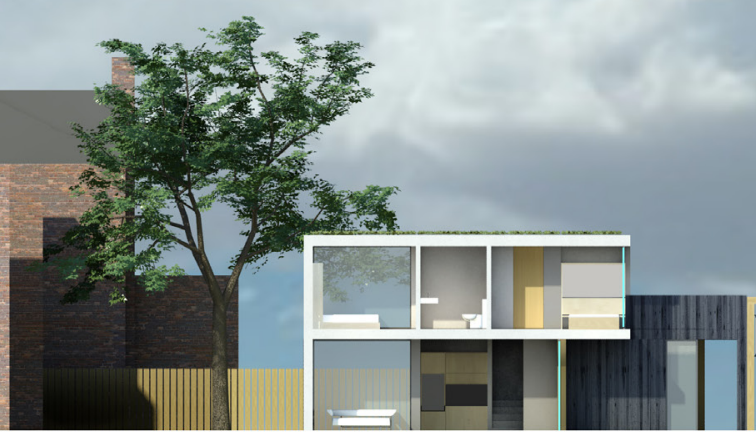

B: Section looking West.

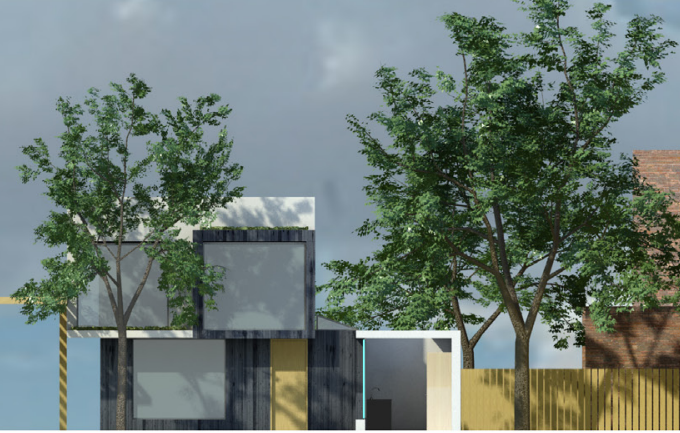

Figure 5-08 Proposed Sections. 


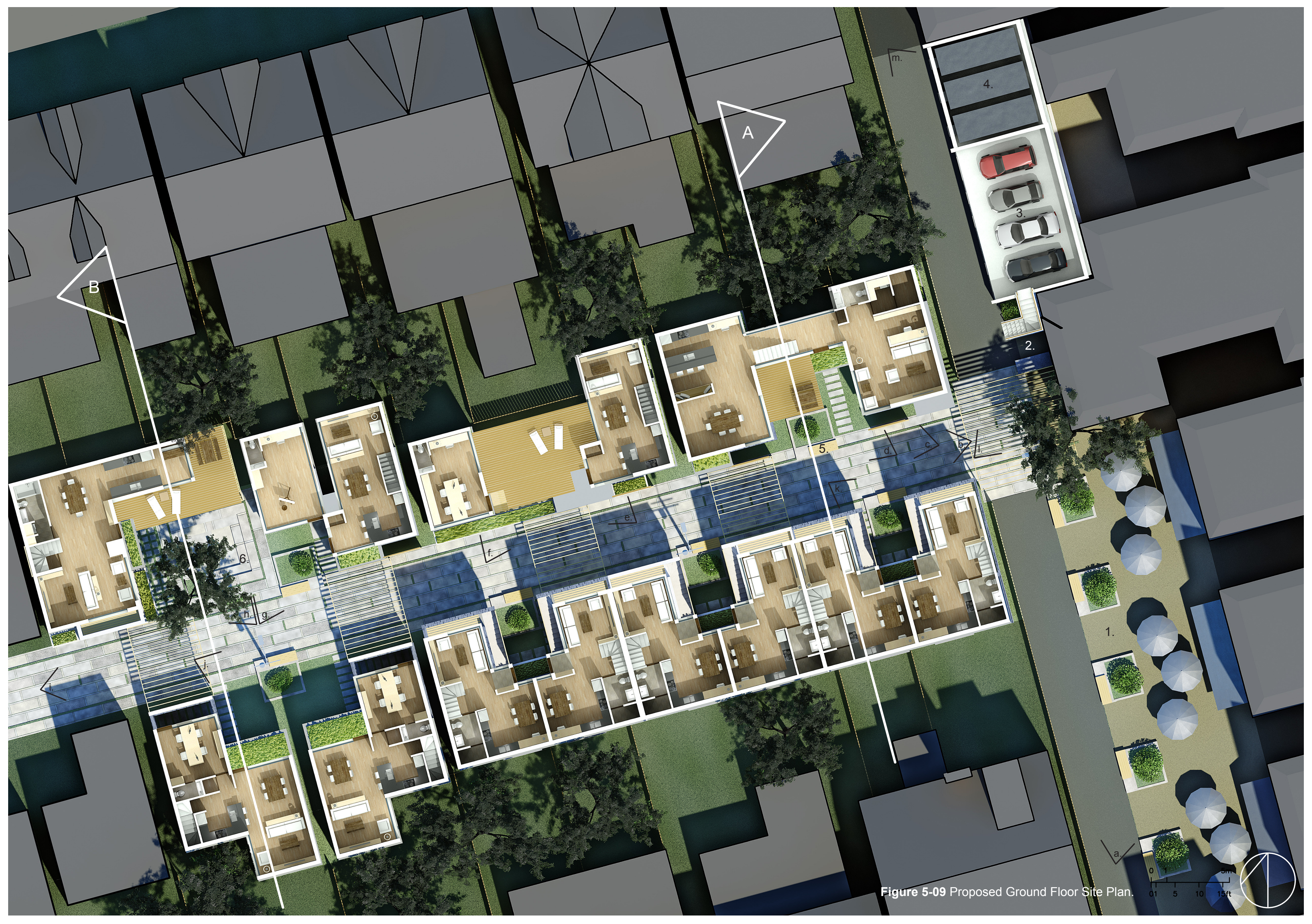




\section{A Design Tour}

The following is a pictorial tour of the final design manifestation of this thesis. Its goal is to introduce the reader to the cumulated exploration of the third intention of this thesis; how architecture can begin to envision the potentials of Toronto's laneways to foster the growth of unique and desirable mid-block communities.

Please refer to figure 5-09 for tour stops.
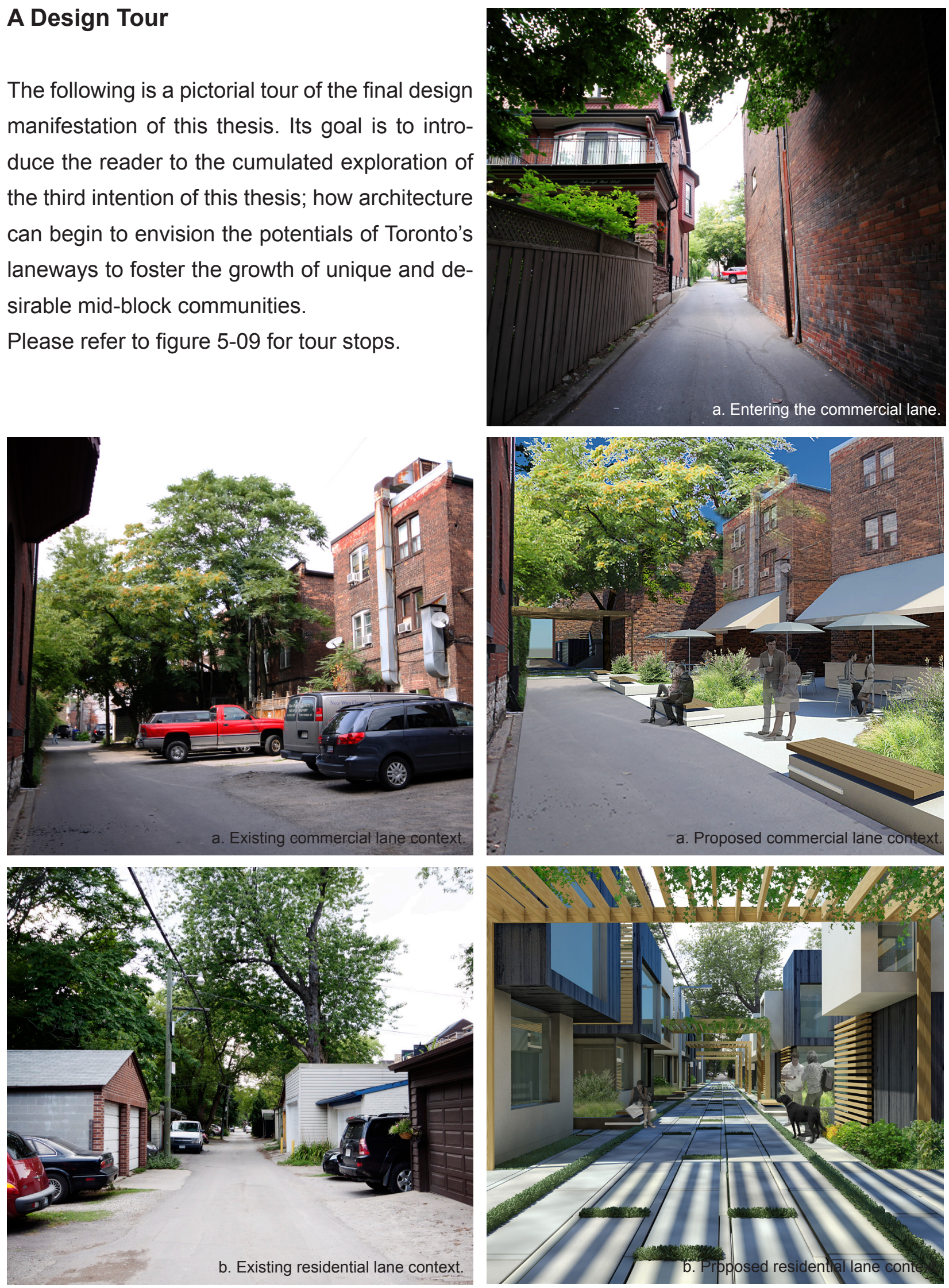

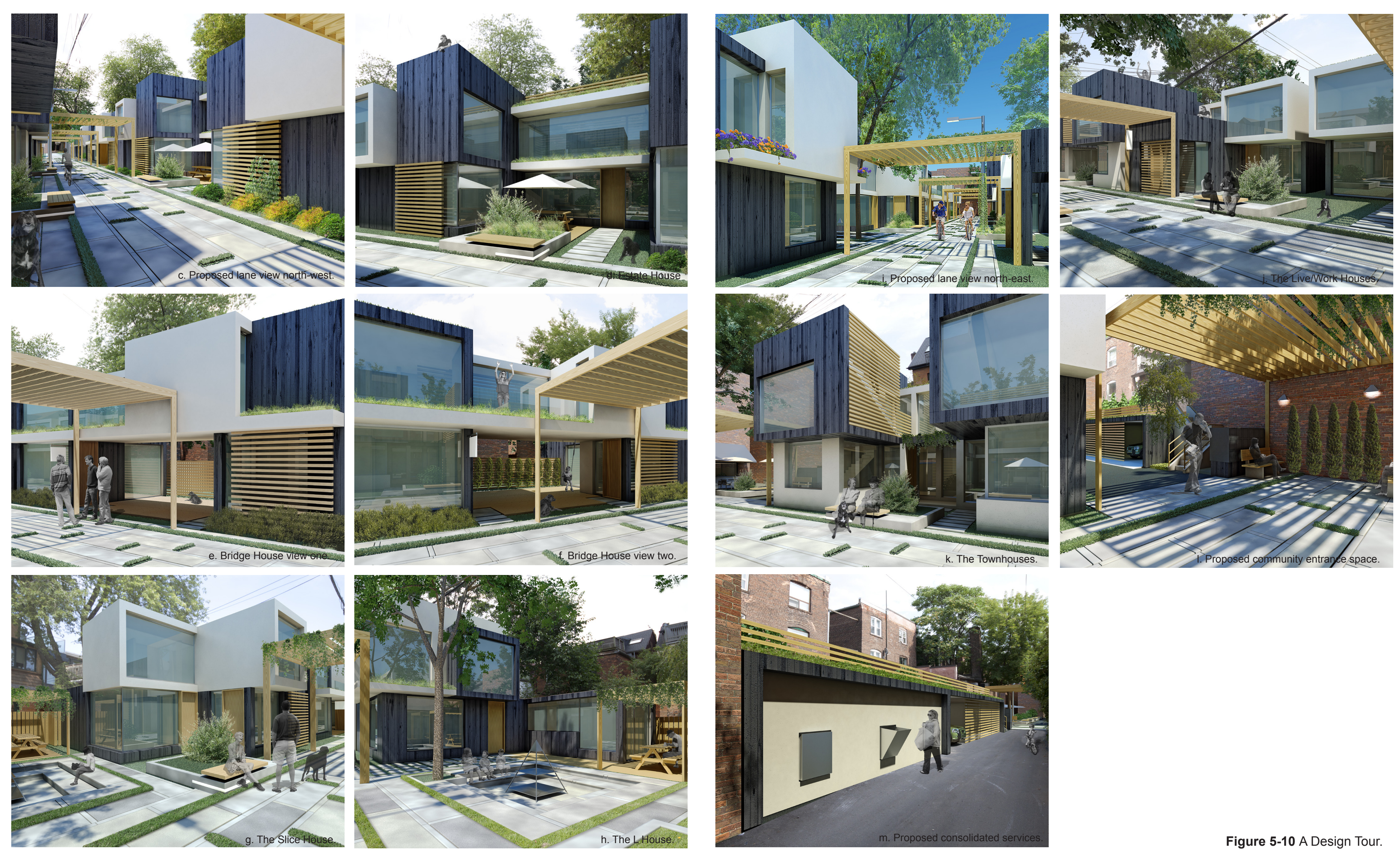

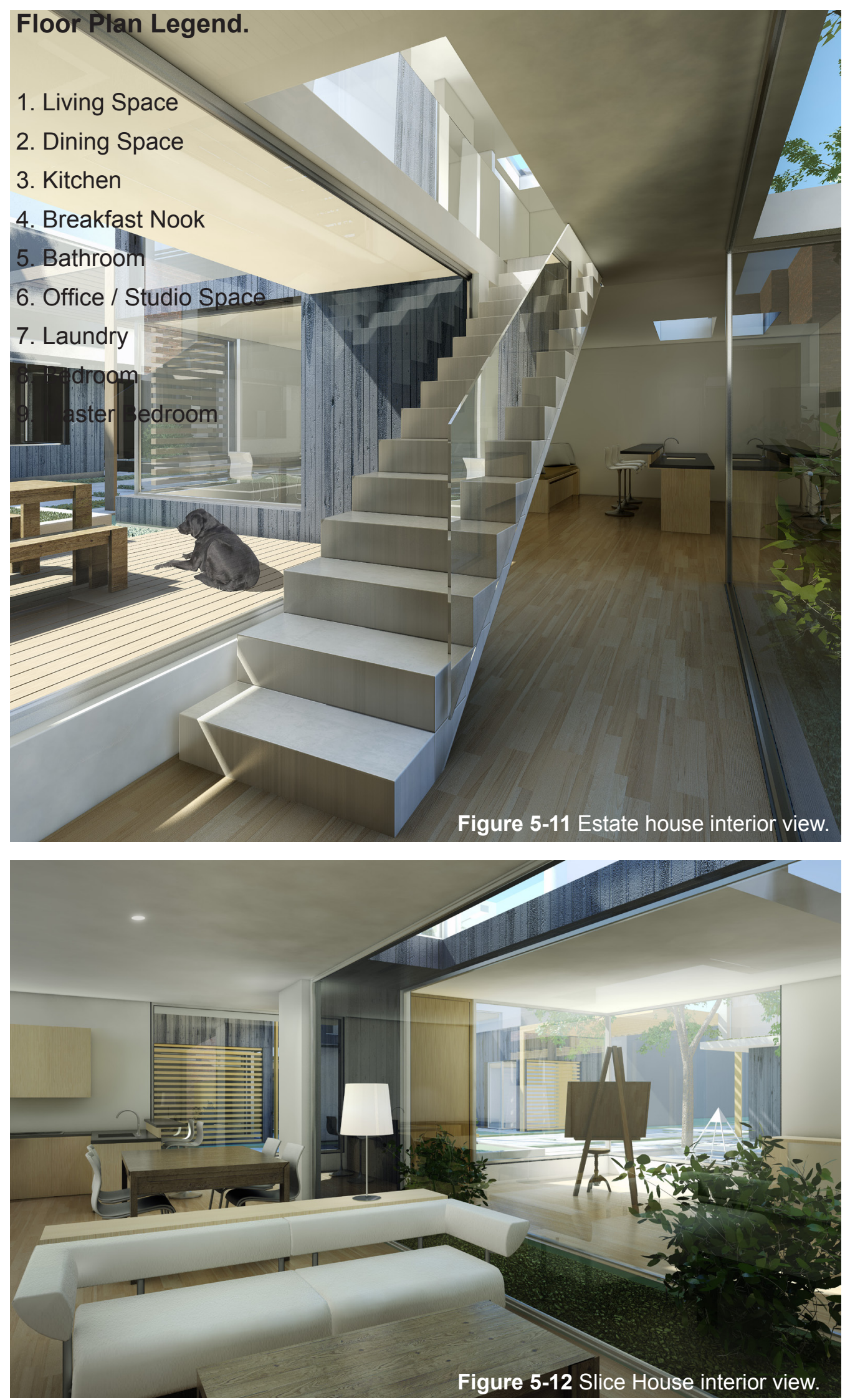

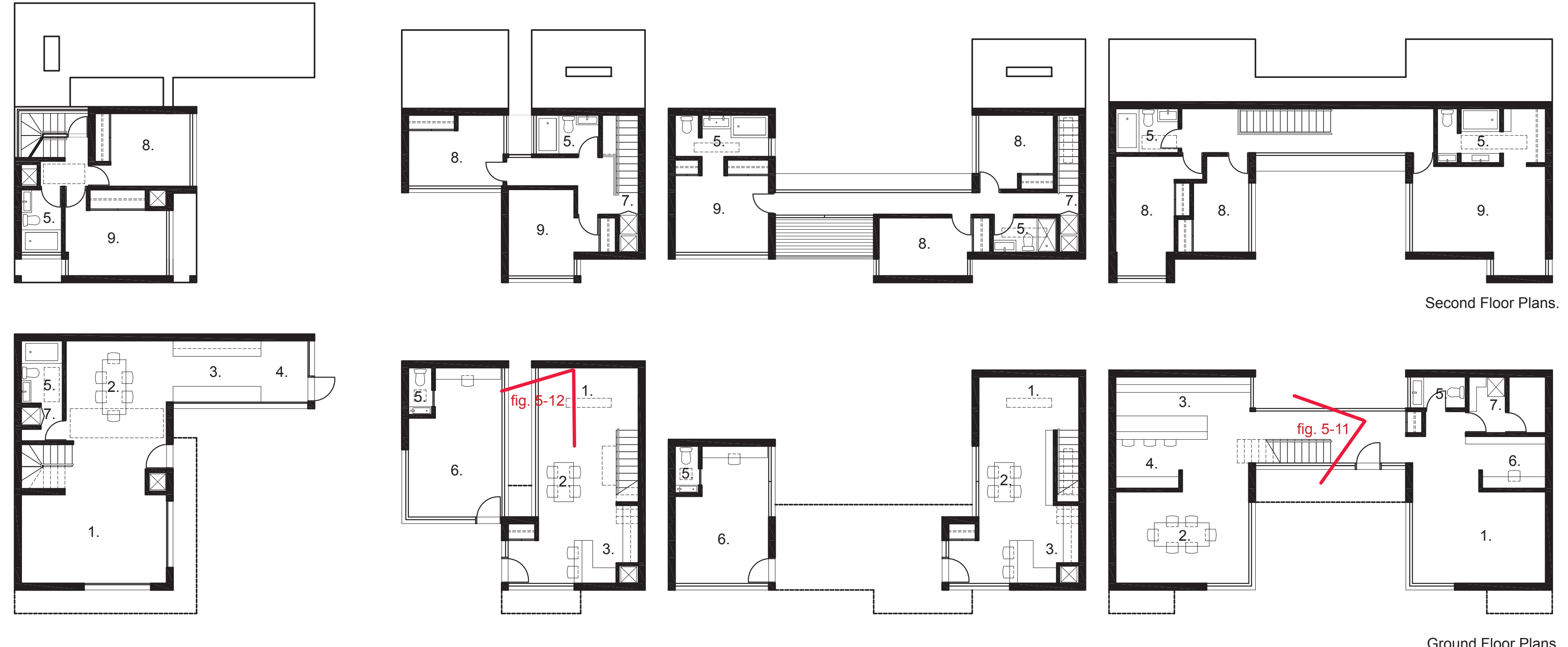

The L House. (Single Family). Total Area: $99 \mathrm{~m}^{2}\left(1070 \mathrm{ft}^{2}\right)$

The Estate House. (Single Family).

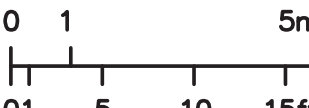

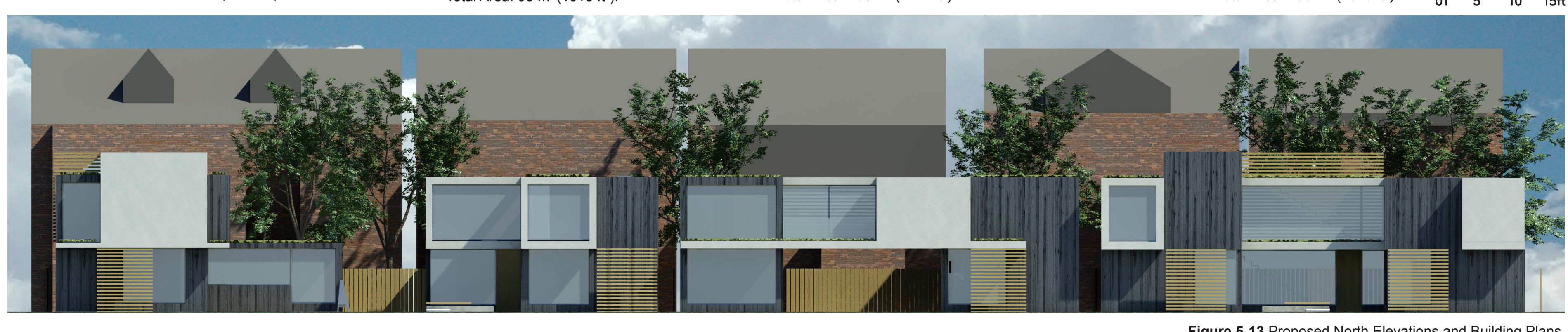



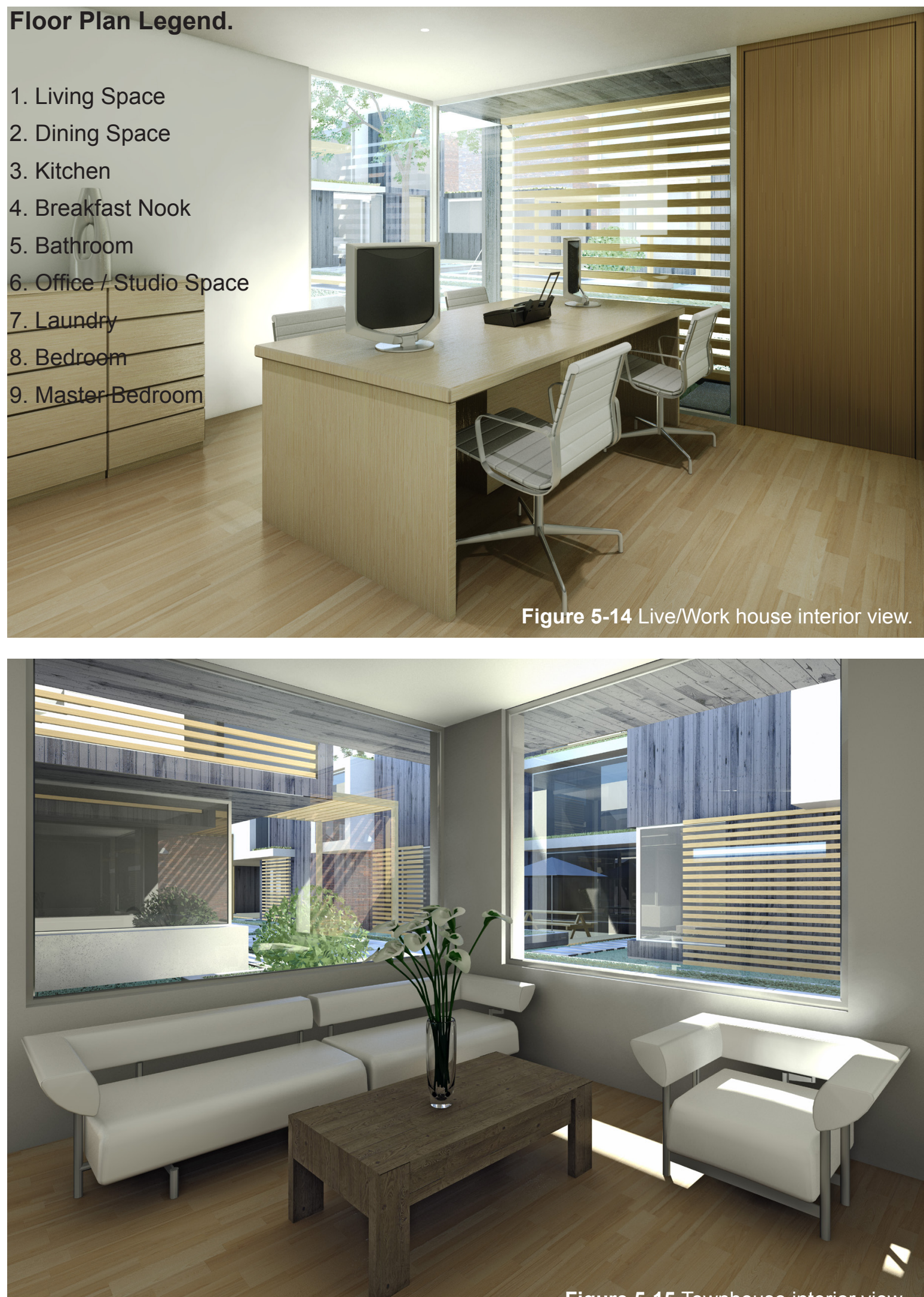

Figure 5-15 Townhouse interior view. 

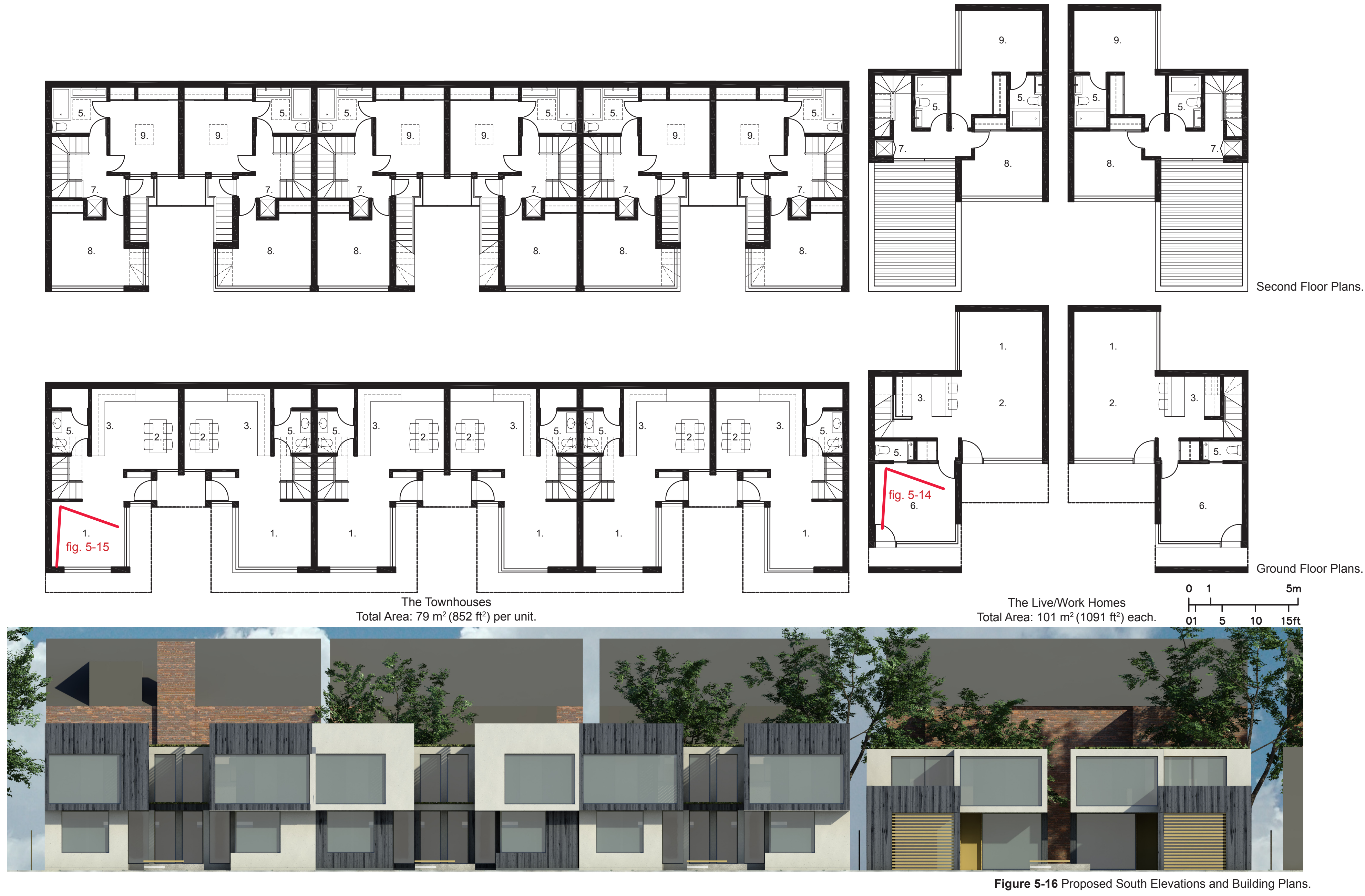


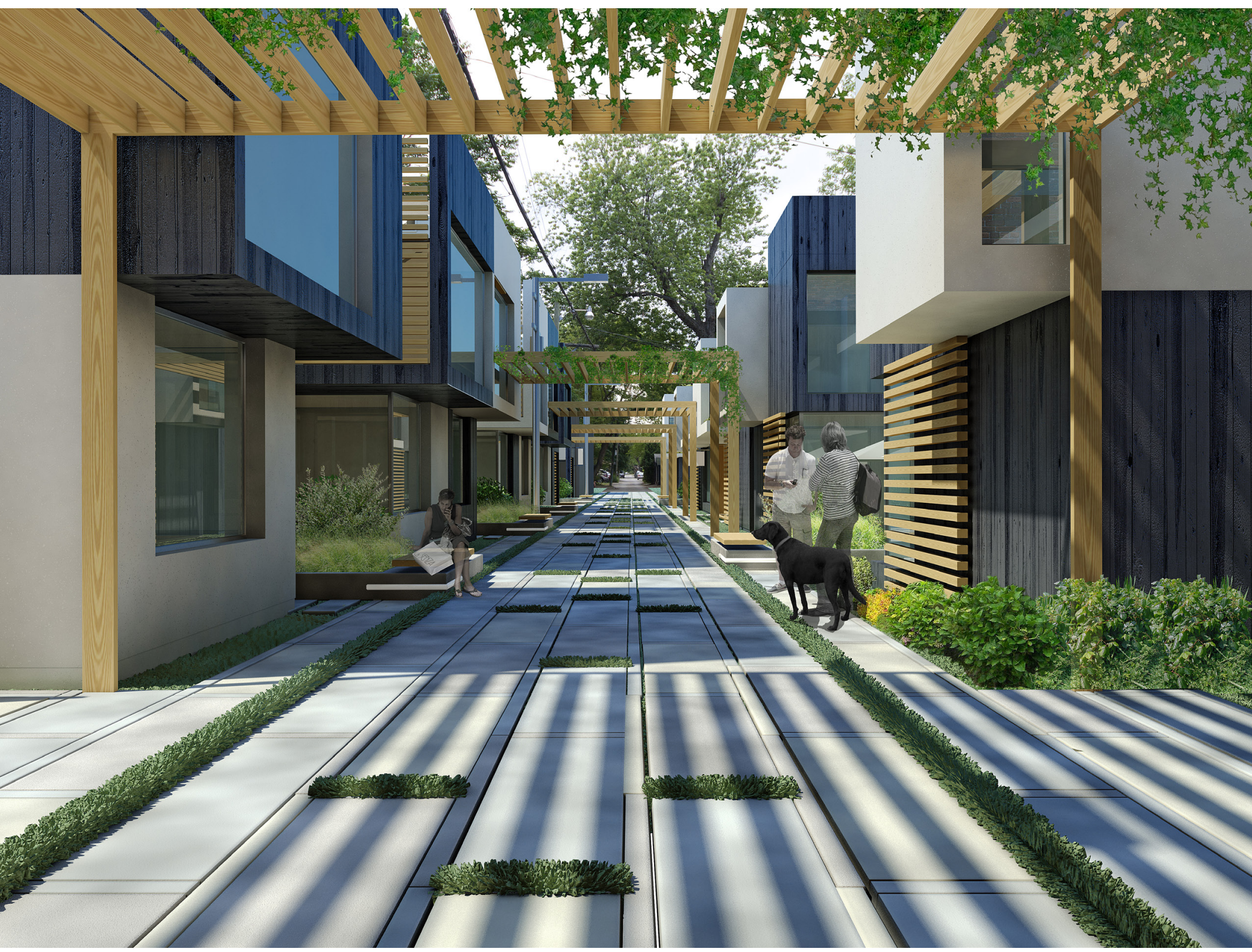

Figure 5-17 Proposed Lane View West. 


\section{Further Considerations}

The intention of this thesis was to use architecture as a guiding tool to achieve three goals; to prove, imagine and explore the potentials of laneway housing in the City of Toronto. The final design manifestation, it can be argued, provides an image of the possibility of Toronto's laneways to support the growth of unique and desirable mid-block communities.

Although this thesis addressed the numerous issues surrounding laneway housing development in Toronto and attempted to provide design solutions and suggestions, it does not claim to have found all the answers. On the contrary, through this process and design exploration many new considerations have arisen.

For example, while this thesis confirmed that Toronto's urban form can support the laneway housing typology, careful consideration must be taken into the understanding of how this typology can be constructed in such constrictive circumstances. While prefabrication of building materials would minimize the construction time, and aid in erection of these buildings on narrow lots, the accessibility of the necessary machinery for prefabricated construction, such as cranes, would be difficult. As a result, further research needs to be completed on developing a construction method suitable for the laneway housing typology.

Another topic that was only lightly touched on in this thesis was the relationship between the back of the laneway dwelling and the open space of the principal dwelling. While it has been suggested that the glazing and open space of the laneway house be directed away from the principal dwelling due to privacy and overlook issues, further considerations need to be made in how to mediate the relationship between these two spaces. The adverse issues associated with privacy and overlook may manifest 
themselves in an undesirable back laneway facade. This thesis concentrated on the relationship of the laneway dwelling to the lane, investigating architectural form and lane-scaping methods to improve this interaction, the same must be investigated for the interaction between the laneway and principal dwellings.

Another important topic that requires further investigation is that of servicing laneway developments. While proposals were made for the consolidation of mail and garbage, further research should be done on the possibility of consolidating energy services for laneway communities. Argued in this thesis as a more sustainable housing typology because it aids in density increase, laneway housing should also be serviced by passive strategies. Radiant, in floor heating/cooling, cross ventilation (which would need careful design due to the restrictive location of window openings), solar harvesting, water harvesting and geothermal, are some strategies that should be investigated for their consolidated service potentials in laneway housing communities.

The subject of laneway housing encompasses many fields, such as architecture, urban planning, engineering etc, and is not nearly exhausted. It requires the cooperation of all these fields, together with the City of Toronto and resident groups in order to work towards ideal solutions for the laneway housing typology. I encourage those interested in seeing the laneway housing typology one day become present in Toronto's laneways to continue building a solid case for why and how laneway housing can one day become part in parcel of Toronto's urban form. 


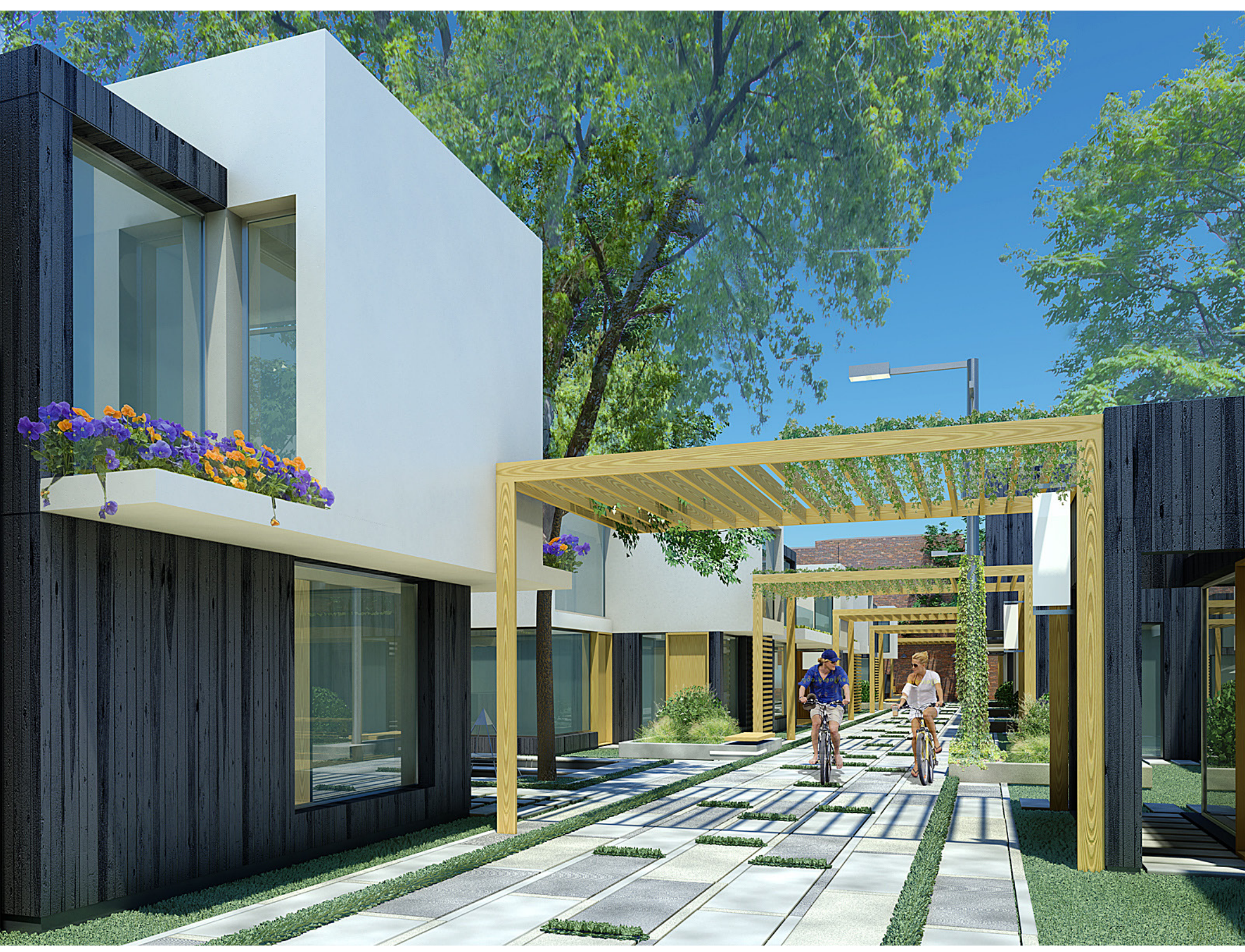

Figure 5-18 Proposed Lane View East. 


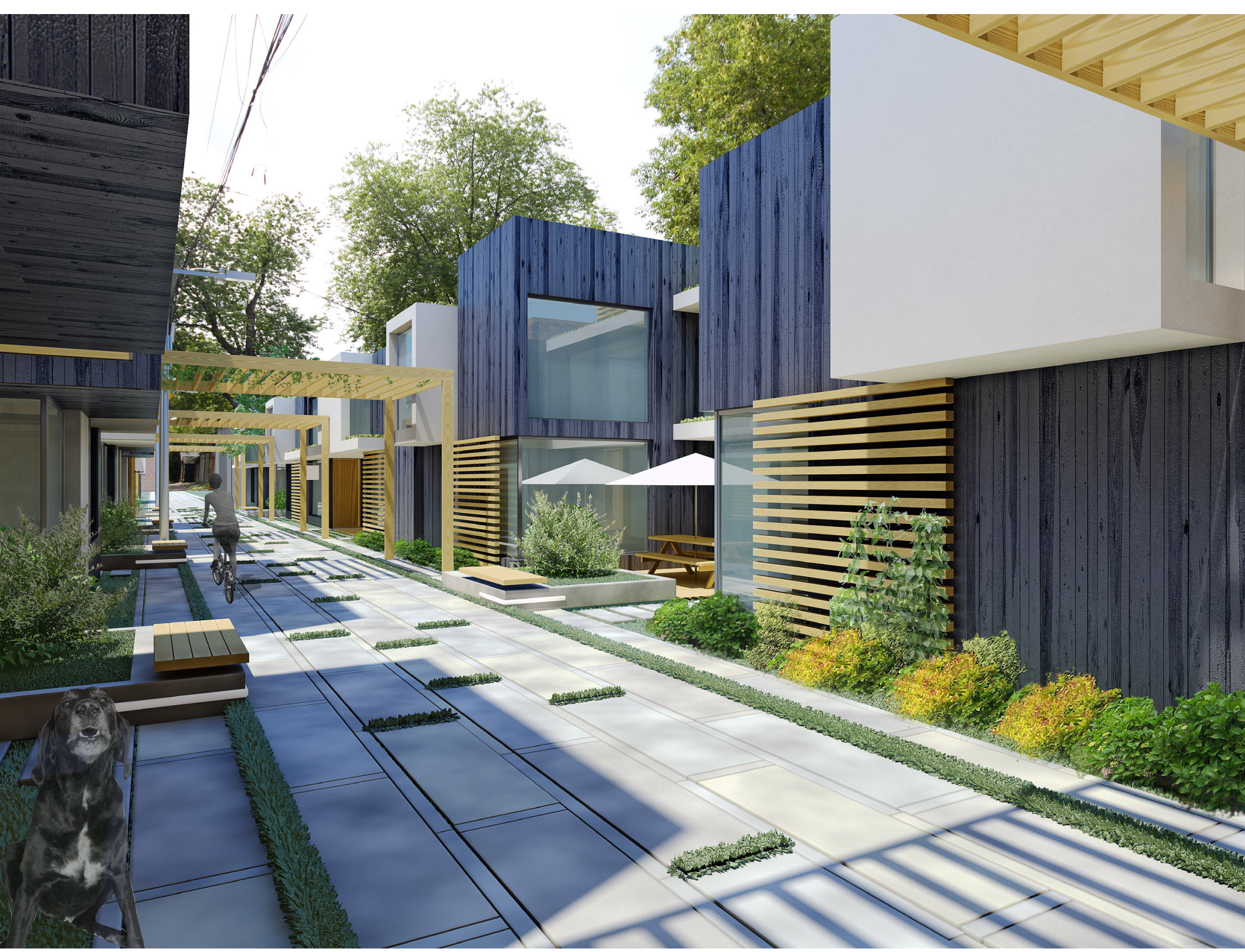

Figure 5-19 Proposed Lane View North West. 


\section{Final Thoughts}

Inspired by existing laneway housing form in the City of Toronto, the opportunities for laneway housing development, and the approval of this type of building typology in Vancouver and Seattle, the intent of this thesis was to explore the potentials of the laneway housing typology in the context of Toronto's urban form. The findings gathered from precedent studies, and research presented in the review of literature confirm that significant opportunities exist for laneway housing development.

With an extensive, under-utilized existing laneway network, the City of Toronto contains the necessary infrastructure to support this type of housing development. Evidence gathered in $A$ Study of Laneway Housing in Toronto (Stinson \& Van Elslander, 2003), highlights the potential significant increase in ground related housing form in the City of Toronto if laneway housing was approved by right and recognized as a legitimate housing typology. The approval of laneway housing development would alleviate Toronto's growing housing pressures and provide an affordable housing typology for the vulnerable population in need of ground related housing in areas where it is needed most (in established neighbourhoods, close to public transit and necessary amenities).

Laneway housing development, as a form of infill, also offers significant opportunities in supporting sustainable development practices. Densification, is a key characteristic of sustainable development and smart growth initiatives. The construction of laneway housing in established neighbourhoods would increase housing density without destroying the existing character of these areas, while providing a housing typology that supports walkability, the use of public transit and the potential to relieve the dependence on automobile reliant suburban sprawl housing developments. 
While the Old (pre-amalgamated) City of Toronto's existing lot sizes contain a more restrictive urban form than Vancouver and Seattle's lots they can still accommodate laneway housing based on the precedent criteria established for this type of development. This thesis has found that while the allowances for existing lot coverage in the City of Toronto would have to be increased, it concludes that the potential housing density increase is significant and argues that lot severance for the purpose of laneway housing development would simply be an evolution of historical urban form development patterns. More considerate than high-rise/high density developments, laneway housing has the potential to increase Toronto's housing density significantly without destroying the existing character of Toronto's established neighbourhoods.

A significant amount of the City of Toronto's existing lots can support the development of acceptable housing form. Though some of these laneway houses may be small in size, they provide a relationship to the street that high-rise/high-density units (comparable in size) cannot and can be designed for appropriate functionality in a way that minimizes the 'adverse affects' associated with this housing typology such as overlook / privacy, shadowing issues etc.

Lastly, this thesis has found that if the laneway housing typology is designed not on a lot by lot basis, but from the perspective of its evolution in the entire laneway context, this housing typology has the potential to foster the growth of strong and desirable communities. Laneway housing can set a precedent for living in closer proximity with our neighbours, for sharing services and open space. 
Lot severance will ultimately be determined by the current land owners and as a result will be sporadic and unpredictable. While this thesis looks at the possibility of numerous lots being severed and consolidated on the same laneway, this type of lot severance may not be true of the near future in the City of Toronto. However, if societal changes continue moving towards patterns of re-urbanization and density; if people continue to want to live in urban centres that contain necessary amenities, reducing their requirements in the size of the typical family home, and increase their use of more sustainable transportation forms - if society recognizes the overwhelming benefits of living in each others company in established and vibrant neighbourhoods, the push for lot re-subdivision may be fed by the demand of future societal needs.

However, in order for this to happen, the City of Toronto and its policy makers must recognize the opportunities available in the approval of laneway housing development. Laneway housing must be recognized by the Toronto Official Plan as a legitimate and opportune form of infill in established residential neighbourhoods and subsequent zoning policies must be amended to encourage this type of development.

The potentials for laneway development as well as the opportunities they present to the City of Toronto must continue to be made manifest. The education of the residents of the City of Toronto is integral to acceptance of this housing typology and to encourage its development. It is through continual exploration of this topic, and the envisioning of the potentials of laneway housing, that we may one day live to see Toronto's mid-block communities flourish. 



\section{Table Credits}

${ }^{*}$ All tables not listed below are credited to the Author.

2-01

Number and Length of Public Laneways in each Community Council Area. Consolidated Clause in Works Committee Report 5. Construction of Housing in Laneways (All Wards). City of Toronto. City Clerks Office. 2006.

\section{2-02}

Forecasted GTA Population. Tyndorf, T. (2006). City of Toronto. Toronto Plan. Flashforward Addendum: Projecting Housing Demand by Tenure to 2031. City Planning Division. Retrieved February 17, 2010 from http://www.toronto.ca/torontoplan/pdf/flashforward_addendum.pdf.

\section{2-03}

The City of Toronto's Housing Surplus and Shortfall. Tyndorf, T. (2006). City of Toronto. Toronto Plan. Flashforward Addendum: Projecting Housing Demand by Tenure to 2031. City Planning Division. Retrieved February 17, 2010 from http://www.toronto.ca/torontoplan/pdf/flashforward_addendum.pdf.

2-04

Proximity to Daily Amenities. Canadian Mortgage and Housing Corporation. (2011). Retrieved June 10, 2011 from http://www.cmhc-schl.gc.ca/en/co/buho/sune/sune_006.cfm\#CP_JUMP_98623. 



\section{Figure Credits}

${ }^{*}$ All figures not listed below are credited to the Author.

\section{i-01}

Laneway House: 7 Leslie Garden Lane. As cited in: TO Built. Krawczyk, Bob. (2010). Retrieved November 16, 2010 from http://www.tobuilt.ca/php/tobuildings_more.php?search_fd3=9004.

$\mathrm{i}-06$

Suburban Sprawl in Markham. Bock, Tony. The Toronto Star. (May 31, 2008). Retrieved September 13, 2010 from http://www.thestar.com/News/article/434427.

\section{i -07}

Toronto Waterfront Condos. Toronto Condos Blog. (June 20, 2011). Retrieved July 2011 from http://torontocondosblog.wordpress.com/.

\section{$\mathrm{i}-08$}

[No Title]. Geller, Michael. (July 29, 2009). Michael Geller's Blog. Retrieved September 13, 2010 from http://gellersworldtravel.blogspot.com/2009/07/life-in-back-lane-toronto-style.html.

\section{$\mathrm{i}-10$}

[No Title]. Geller, Michael. (July 29, 2009). Michael Geller's Blog. Retrieved September 13, 2010 from http://gellersworldtravel.blogspot.com/2009/07/life-in-back-lane-toronto-style.html.

$\mathrm{i}-11$

[No Title]. Geller, Michael. (July 29, 2009). Michael Geller's Blog. Retrieved September 13, 2010 from http://gellersworldtravel.blogspot.com/2009/07/life-in-back-lane-toronto-style.html.

$\mathrm{i}-09$

40R Shaftesbury Ave. As cited in: Blog TO. Pasold, Lisa (September 22, 2009). Retrieved September 13, 2010 from http://www.blogto.com/city/2009/09/toronto_urban_design_awards/.

\section{1-03}

Capri, Italy. Retrieved May 12, 2011 from http://www.newurbanism.org/newurbanism.html.

\section{1-04}

Pedestrian-friendly Markham. Sgro, Christine. (2011). The Urban Design Forum. Retrieved February 10, 2011 from: http://udf.org.au/udf-quarterly/udfq-91-september-2010/article/new-urbanism-the-face-oftoronto-suburbs/.

\section{1-05}

Sectional Perspective. Myers, B; Baird, G. (1978). Vacant Lottery. Design Quarterly, No. 108, p. 37. Retrieved January, 2011 from http://www.jstor.org/stable/4090990.

\section{$1-06$}

[No Title]. Myers, B; Baird, G. (1978). Vacant Lottery. Design Quarterly, No. 108, p. 39. Retrieved January, 2011 from http://www.jstor.org/stable/4090990. 



\section{1-07}

Aerial View of Completed Project. Myers, B; Baird, G. (1978). Vacant Lottery. Design Quarterly, No. 108, p. 38. Retrieved January, 2011 from http://www.jstor.org/stable/4090990.

\section{1-08}

View From Belgrave Place. Firley, E; Stahl, C. (2009). The Urban Housing Handbook. West Sussex, England: John Wiley and Sons, Ltd, p. 106.

\section{$1-09$}

Urban Plan. Firley, E; Stahl, C. (2009). The Urban Housing Handbook. West Sussex, England: John Wiley and Sons, Ltd, p. 109.

\section{$1-10$}

Washington Mews. As cited in: Forgotten New York. Walsh, Kevin. [No Date]. Retrieved May 15, 2010 from http://www.forgotten-ny.com/Alleys/GREENWICH\%20VILLAGE/green.html.

\section{$1-12$}

[No Title]. Chapin, R. (2011). Pocket Neighborhoods. Newton, CT: The Taunton Press, p. 102.

\section{$1-13$}

[No Title]. Chapin, R. (2011). Pocket Neighborhoods. Newton, CT: The Taunton Press, p. 101.

\section{$1-14$}

[No Title]. Chapin, R. (2011). Pocket Neighborhoods. Newton, CT: The Taunton Press, p. 28.

\section{1-15}

Haarlem, Netherlands. Burden, Dan. (2006). Pedestrian and Bicycle Information Centre Image Library. Retrieved March 2, 2011 from http://www.pedbikeimages.org/pubdetail.cfm?picid=397.

\section{1-16}

Woonerf Design. As cited in: Panayotova, Tzeta. (July 2002). Ecology of the Street. The Journal of Undergraduate Research. Volume 6, Issue 9. Retrieved March 2, 2011 from. http://www.clas.ufl.edu/jur/200207/ papers/paper_panayotova.html

\section{1-17}

[No Title]. Attarian, J.L. (2010). The Green Alley Handbook. City of Chicago. Streetscapes and Urban Design Program. Department of Transportation, p.4. Retrieved January 20, 2011 from http://www.cityofchicago.org/content/dam/city/depts/cdot/Green_Alley_Handbook_2010.pdf.

\section{$1-18$}

[No Title]. Cassidy, A; Newell, J; Wolch, J. (2008). Transforming Alleys into Green Infrastructure for Los Angeles. USC Centre for Sustainable Cities, p. 22. Retrieved November, 2010 from http://www.chc-inc. org/downloads/CASLA\%20Alleyway\%20Report.pdf.

\section{1-19a}

Images of Mole Hill. (2011). The Mole Hill Community Housing Society. Retrieved March 2011 from http:// www.mole-hill.ca/about/images-of-mole-hill/.

\section{$1-19 b$}

A True Neighbourhood. (May 23, 2005). West End Residence Association. Retrieved December 3, 2010 from http://www.wera.bc.ca/legacy/index.php?blogid=1\&archive=2005-05. 

1-20

Figure 4.26. Friedman, A. (2002). Planning the New Suburbia. Flexibility by design. Vancouver, Toronto: UBC Press, p. 80.

\section{1-21}

6.24 Lots with Alleys. Friedman, A. (2007). Sustainable Residential Development. Blacklick, OH, USA: McGraw-Hill Professional Publishing, p. 223.

\section{$1-22$}

City of Vancouver. (2009). Laneway Housing. Illustrative Examples. p. 7. Retrieved August 2010 from http://vancouver.ca/commsvcs/lanewayhousing/regulations.htm.

\section{$1-23$}

City of Seattle. Department of Design, Construction and Land Use. (June 20, 2003). Evaluation of the 1998-2001 Demonstration Program for Innovative Housing Design: Detached ADUs and Cottages. Retrieved August 15, 2010 from http://www.seattle.gov/dpd/Planning/Alternative_Housing_Choices/DemonstrationProgram/default.asp.

\section{1-24}

Laneway Housing. City of Vancouver. (March 24, 2011). Retrieved April 2011 from http://vancouver.ca/ commsvcs/lanewayhousing/.

\section{1-25}

Seattle Cottages. As cited in: Griswold, Kent. (May 27th, 2010). The Tiny House Blog. Retrieved September 2010 from http://tinyhouseblog.com/tiny-house/seattle-backyard-cottages/.

\section{2-01}

ORTH176280483502005FBS. Adapted from City of Toronto Orthophotos 2007. Retrieved November 2010 from Ryerson University.

\section{2-03}

Adapted from: Shim, B; Chong, D. (Eds). (2004). Site Unseen. Laneway Architecture \& Urbanism in Toronto. Toronto : University of Toronto Faculty of Architecture, Landscape, and Design.

AND

Map 22, 28, 31 and 35. As Cited in: Martyn, L.B. (1982) The Face of Early Toronto. An Architectural Record 1797-1936. Sutton West \& Santa Barbara: The Paget Press.

\section{2-04}

Adapted from: Shim, B; Chong, D. (Eds). (2004). Site Unseen. Laneway Architecture \& Urbanism in Toronto. Toronto : University of Toronto Faculty of Architecture, Landscape, and Design.

\section{2-05}

Lane between Taylor and Dundas.(Sept. 23, 1936). City of Toronto Archives. Fonds 200, Series 372, Subseries 33, Item 68.

\section{2-06}

Street Cleaning Department - Lane Scenes. (194-?). City of Toronto Archives. Fonds 200, Series 372, Subseries 100, Item 632. 



\section{2-07}

1, 3 Turners Lane. (Nov. 13, 1936). City of Toronto Archives. Fonds 200, Series 372, Subseries 33, Item 94.

\section{2-08}

Rear from lane 232A 226-228 Lippincott St. (June 12, 1952). City of Toronto Archives. Fonds 200, Series 372 , Subseries 33b, Item 354.

\section{2-09}

Lane rear of 40-44 Wellington St. E. (March 10, 1916). City of Toronto Archives. Fonds 200, Series 372, Subseries 58, Item 541.

\section{2-10}

Slum - Price's Lane. (August 27, 1914). City of Toronto Archives. Fonds 200, Series 372, Subseries 32 , Item 320.

\section{2-11}

Rear of 215 Margueretta Street - Stable. (December 10, 1929). City of Toronto Archives. Fonds 200, Series 372, Subseries 3, Item 751.

\section{2-15}

Adapted from: Shim, B; Chong, D. (Eds). (2004). Site Unseen. Laneway Architecture \& Urbanism in Toronto. Toronto : University of Toronto Faculty of Architecture, Landscape, and Design.

\section{2-17}

Sample Study Area: Laneway Housing Sites. Stinson, J; Van Elslander, T. (2003). A Study of Laneway Housing in Toronto. (unpublished).

\section{2-18}

As cited in: Metapolis: Urban and Regional Research. (February 7th, 2011). Retrieved April 4, 2011 from http://www.metapolis.ca/wordpress/?p=23.

\section{2-19}

As cited in: Toronto Condos Blog. (November 16, 2009). Retrieved July 2011 from http://torontocondosblog.wordpress.com/2009/11/16/high-rise-apartments-reveal-a-new-perspective/.

\section{2-20}

www.maps.google.ca

\section{2-21}

USA As The Uni-Centered City. As cited in: Myers, B; Baird, G. (1978). Vacant Lottery. Design Quarterly, No. 108, p. 8. Retrieved January, 2011 from http://www.jstor.org/stable/4090990.

\section{2-22}

Toronto Skyline. As cited in: http://www.alllake.org/toronto.html. Retrieved April 12, 2010.

\section{2-23}

Ontario greenbelt 2.0. GreenBelt. (2011). Retrieved on April 12, 2011 from http://www.greenbelt.ca/ maps/ontarios-greenbelt-20. 



\section{2-24}

Measuring Intensification Rates. The Neptis Foundation. Implementing Residential Intensification Targets: Lessons from Research on Intensification Rates in Ontario. Library and Archives Canada Cataloguing in

Publication, p. 7.

\section{2-25}

Neighbourhood Types. Canadian Mortgage and Housing Corporation. (2011). Retrieved June 10, 2011

from http://www.cmhc-schl.gc.ca/en/co/buho/sune/sune_006.cfm\#CP_JUMP_98623.

\section{2-26}

Adapted from: $50 \mathrm{H}-21$. (August 2010). City of Toronto Zoning By-law 1156-2010 - Schedule "B". Retrieved March 202010 from http://www.toronto.ca/zoning/.

\section{2-27}

www.maps.google.ca

\section{2-28}

www.maps.google.ca

\section{2-29}

www.maps.google.ca

\section{2-30}

www.maps.google.ca

\section{2-31}

Peyton Lane Terrace. Van Elslander Carter Architects Incorporated. Retrieved February 16, 2011 from http://www.tvearch.com/residential/peyton.html.

\section{2-32}

Bikes and cars: living together in harmony. Coop ECTO. As Cited in: by Mcgraph, John Michael. Torontolife.com (October 19, 2010. Retrieved June 2, 2011 from http://www.torontolife.com/daily/informer/intransit/2010/10/19/bixi-bike-share-program-has-1000-members-thanks-to\%E2\%80\%A6a-car-company/.

\section{2-33}

Retrieved on June 2, 2011 from http://www.autoshare.com/aptcoop/metcap.html.

\section{2-34}

Present Day Highway 2A (Toronto). Bevers, Cameron. (May 30, 2004). Retrieved June 2, 2011 from http://www.thekingshighway.ca/PHOTOS/Hwy2A_torontophotos.htm.

\section{2-36}

Tour 1 \& Tour 3. Parry, Graeme. (2011). Retrieved April 2011 from http://www.graemeparry.com/Site/Toronto_Laneways.html.

\section{2-37}

Award of Excellence: Building in Context - Private - Low-scale building. 40R_Laneway House. City of Toronto. Urban Design Awards. (2009). Retrieved March, 2010 from http://www.toronto.ca/tuda/2009/ excellence-private-low-scale-building.htm. 



\section{2-38}

Honourable Mention Building in Context - Private Low-scale building. Laneway House. City of Toronto. Urban Design Awards. (2007). Retrieved March, 2010 from http://www.toronto.ca/tuda/winners/2007/2007_building_honourable_laneway.htm.

\section{2-39}

Visions and Master Plans - Award. Laneway Architecture and Urbanism. City of Toronto. Urban Design Awards. (2003).Retrieved March, 2010 from http://www.toronto.ca/auda/2003/a_laneway_architecture_urbanism.htm.

\section{2-40}

Awards of Excellence - Buildings. 1 Ways Lane. City of Toronto. Urban Design Awards. (2001). Retrieved March, 2010 from http://www.toronto.ca/auda/bldg_award_ex_wayslane_2001.htm.

\section{2-41}

Toronto Intersection, 1948-1973. Myers, B; Baird, G. (1978). Vacant Lottery. Design Quarterly, No. 108, p. 22. Retrieved January, 2011 from http://www.jstor.org/stable/4090990.

\section{2-42}

Section 4 (11)a. City of Toronto Zoning By-law 438-86 - Schedule "A".

\section{3-01}

Adapted from: Shim, B; Chong, D. (Eds). (2004). Site Unseen. Laneway Architecture \& Urbanism in Toronto. Toronto : University of Toronto Faculty of Architecture, Landscape, and Design.

AND

Map 22, 28, 31 and 35. As Cited in: Martyn, L.B. (1982) The Face of Early Toronto. An Architectural Record 1797-1936. Sutton West \& Santa Barbara: The Paget Press.

\section{3-04}

Sherbourne Lanes. Myers, B; Baird, G. (1978). Vacant Lottery. Design Quarterly, No. 108, p. 12. Retrieved January, 2011 from http://www.jstor.org/stable/4090990.

\section{3-05}

Shim, B; Chong, D. (Eds). (2004). Site Unseen. Laneway Architecture \& Urbanism in Toronto. Toronto : University of Toronto Faculty of Architecture, Landscape, and Design, p. 21.

\section{3-06}

Adapted from: Shim, B; Chong, D. (Eds). (2004). Site Unseen. Laneway Architecture \& Urbanism in Toronto. Toronto : University of Toronto Faculty of Architecture, Landscape, and Design, p. 14.

\section{3-12}

The Arts and Crafts 750. Smallworks Studios / Laneway Housing Inc. Retrieved July 10, 2011 from http:// www.smallworks.ca/gallery/index.html.

\section{3-13}

Wike, David. As Cited in: City of Seattle. Seattle Planning Commission. Department of Planning and Development. (2010). A guide to building a backyard cottage, p. 4. Retrieved on August 10, 2010 from http://www.seattle.gov/dpd/Codes/BackyardCottages/Overview/. 



\section{3-14}

City of Vancouver. (2009). Laneway Housing. Illustrative Examples. p. 4. Retrieved August 2010 from http://vancouver.ca/commsvcs/lanewayhousing/regulations.htm.

\section{3-15}

Magnolia detached ADU. City of Seattle. Department of Design, Construction and Land Use. (June 20, 2003). Evaluation of the 1998-2001 Demonstration Program for Innovative Housing Design: Detached ADUs and Cottages, p. 8. Retrieved August 15, 2010 from http://www.seattle.gov/dpd/Planning/Alternative_Housing_Choices/DemonstrationProgram/default.asp.

\section{3-16}

Laneway House: 7 Leslie Garden Lane. As cited in: TO Built. Krawczyk, Bob. (2010). Retrieved November 16, 2010 from http://www.tobuilt.ca/php/tobuildings_more.php?search_fd3=9004.

\section{3-21}

Euclid Avenue House. Levitt Goodman Architects. Retrieved May 2010 from http://levittgoodmanarchitects.com/project?p=levittgoodmanhouse \&c1=residential\&c2=None.

\section{3-23}

Laneway House. Arban, Tom. Kohn Shnier Architects. Retrieved May 2010 from http://www.kohnshnierarchitects.com/site.html.

\section{3-25}

40R_Laneway House. superkül inc | architect. Retrieved June 10, 2011 from http://superkul.ca/ projects/40-r-laneway-house\#.

\section{3-26}

40R_Laneway House. Arban, Tom. superkül inc | architect. Retrieved June 10, 2011 from http://superkul. ca/projects/40-r-laneway-house\#. 



\section{Works Cited}

Attarian, J.L. (2010). The Green Alley Handbook. City of Chicago. Streetscapes and Urban Design Pro gram. Department of Transportation. Retrieved January 20, 2011 from http://www.cityofchicago. org/content/dam/city/depts/cdot/Green_Alley_Handbook_2010.pdf.

Blais, P. (2003). Smart Development For Smart Growth. Smart Growth Issues Papers. Neptis Foundation: Library and Archives Canada Cataloguing in Publication. Retrieved September 2010 from http:// www.neptis.org/.

Brytus, N; Fram, M; McClelland, M. (Eds). (2001). East/West. A guide to where people live in downtown Toronto. Coach House Books. Retrieved October 2010 from http://archives.chbooks.com/online_ books/eastwest/contents.html.

Cassidy, A; Newell, J; Wolch, J. (2008). Transforming Alleys into Green Infrastructure for Los Angeles. USC Centre for Sustainable Cities. Retrieved November, 2010 from http://www.chc-inc.org/downl oads/CASLA\%20Alleyway\%20Report.pdf.

Chapin, R. (2011). Pocket Neighborhoods. Newton, CT: The Taunton Press.

City of Vancouver. (2009). Laneway Housing. Illustrative Examples. Retrieved August 2010 from http://vancouver.ca/commsvcs/lanewayhousing/regulations.htm.

City of Vancouver. Land Use and Development Policies and Guidelines. (2009). Laneway House (L.W.H.) Guidelines. Retrieved August, 2010 from http://vancouver.ca/commsvcs/lanewayhousing/regula tions.htm.

Clay, G. (1978). Alleys: A Hidden Resource. Louisville: Grady Clay and Company.

Crowther, W.G. (June, 2006). City of Toronto Staff Report. Construction of Housing in Laneways ALL WARDS. Retrieved February 10, 2010 from http://www.toronto.ca/legdocs/2006/agendas/commit tees/wks/wks060705/it007b.pdf.

Donnelly, D. (January 31, 2010). Making the Case for Higher Density, Rather Than Higher Buildings. SB Magazine. Summer 2010. Retrieved July 2011 from http://www.sbmagazine.ca/archives/659.

City of Vancouver. (2007). EcoDensity. Initial Actions. Retrieved August 2010 from http://vancouver.ca/ commsvcs/ecocity/pdf/actions-FINAL.pdf

Fisher, S. (2009). Livable Lanes: A Study of Laneway Infill Housing in Vancouver and Other Growing B.C. Communities. Canadian Housing and Mortgage Corporation. Retrieved on April 2010 from http:// www.cmhc-schl.gc.ca/en/index.cfm.

Friedman, A \& Krawitz D. (2002). Peeking through the Keyhole. Montreal \& Kingston: McGill \& Queens University Press.

Friedman, A. (2002). Planning the New Suburbia. Flexibility by design. Vancouver, Toronto: UBC Press.

Hulchansky, D. (2010). The Three Cities Within Toronto: Income Polarization Among Toronto's Neighbour hoods, 1970-2005. Cities Centre, University of Toronto. 

IBI Group. (March 2009). Parking Standards Review: Examination of Potential Options and Impacts of Car Share Programs on Parking Standards. Submitted to the City of Toronto. Retrieved April 16, 2011 from http://www.toronto.ca/zoning/pdf/car_share_2009-04-02.pdf.

McConnell, V; Wiley, K. (2010). Infill Development: Perspectives and Evidence from Economics and Planning. Resources for the Future. Retrieved January 2011 from http://www.rff.org/rff/docu ments/RFF-DP-10-13.pdf.

McGinnis, R. (2010, August 11). Future not so bright for laneway housing in Toronto. BlogTo. Retrieved August 15, 2010 from http://www.blogto.com/city/2010/08/future_not_so_bright_for_laneway_ housing_in_toronto/.

Myers, B; Baird, G. (1978). Vacant Lottery. Design Quarterly, No. 108, pp. 1-3+6-51. Retrieved January, 2011 from http://www.jstor.org/stable/4090990.

New Urbanism. (No date provided). Sustainability. Retrieved January 15, 2001 from http://www.newurban ism.org/newurbanism.html.

Oberstein, J. (Curator, Ed.). (2011). Los Angeles. Alleys. (No publisher).

Rogers, R. (1997). Cities for a Small Planet. London: Westview Press.

SFS Planning (2009). Life in the Lane. Mapping Ward 20 Lanes. Toronto, Ryerson University Faculty of Urban Planning.

Shim, B; Chong, D. (Eds). (2004). Site Unseen. Laneway Architecture \& Urbanism in Toronto. Toronto : University of Toronto Faculty of Architecture, Landscape, and Design.

Statistics Canada. (2006). 2006 Census of Population. Statistics Canada catalogue no. 97-554XCB2006028 (Toronto, C Code3520005). Retrieved on May 2, 2010 from http://www12.statcan. gc.ca/census.

Stinson, J; Van Elslander, T. (2003). A Study of Laneway Housing in Toronto. (unpublished).

Stinson, J; Van Elslander, T. (2003). A Study of Laneway Housing in Toronto. Phase Two. (unpublished).

Tyndorf, T. (2006). City of Toronto. Toronto Plan. Flashforward Addendum: Projecting Housing Demand by Tenure to 2031. City Planning Division. Retrieved February 17, 2010 from http://www.toronto.ca/ torontoplan/pdf/flashforward_addendum.pdf.

Tyndorf, T. (2009). City of Toronto. Toronto Official Plan 2007. Retrieved February 15, 2010 from http:// www.toronto.ca/planning/official_plan/introduction.htm.

US EPA. Local Government Commission. (2003). Creating Great Neighborhoods: Density in your commu nity. Retrieved March 10, 2011 from http://www.epa.gov/dced/density.htm.

Vaughan, M. (2004). 35 Peyton Lane. Unpublished Raw Data. 



\section{Extended Reference List}

Ashoka Community Greens. [No Date]. Design Criteria for Backyard Common. Retrieved, May 16, 2011 from http://www.communitygreens.org/designcriteria. (website reference).

Baker, S. (2006). Sustainable Development. New York. Routledge.

Beatley, T. (2000). Green Urbanism: Learning from European Cities. Washington, California. Island Press.

Bula, F. (October 29, 2010). B.C.'s big boom in little houses. The Globe and Mail. Retrieved November 2010 from http://www.theglobeandmail.com/news/national/british-columbia/bcs-big-boom-in-littlehouses/article1779054/singlepage/\#articlecontent.

Burrows, M. (2009, June). Vancouver laneway housing motion approved. Straight.com. Retrieved February 3, 2010 from http://www.straight.com/article-232976/laneway-motion-approved.

Chiotti, Q. (2004). Toronto's Environment: A discussion on urban sprawl and atmospheric impacts. Pollution Probe. Retrieved February 15, 2010 from http://www.pollutionprobe.org/Reports/toron tosenvironment.pdf.

City of Toronto (2005). Development Infrastructure Policy and Standards: Policy and Standards for Public Local Residential Streets And Private Streets. Retrieved October 2010 from http://www. toronto.ca/developing-toronto/darp_guidelines.htm.

City of Toronto. (2011). Parking Standards. Retrieved April 16, 2010 from http://www.toronto.ca/zoning/ parking.htm.

City of Toronto. (2009). 2010 Interim Property Tax Rates. Retrieved February 20, 2010 from http://www. toronto.ca/taxes/property_tax/tax_rates.htm.

City of Vancouver. (2008). Public Feedback Received for Laneway Housing after October 15th, 2008. Re trieved September 2010 from http://vancouver.ca/commsvcs/ecocity/lanewayhousing.htm.

City of Vancouver. (2009) Laneway House (Iwh) Guidelines. Land Use and Development Policies and Guidelines. Retrieved August, 2010 from http://vancouver.ca/commsvcs/lanewayhousing/regula tions.htm.

City of Vancouver. (2008). Policy report urban structure. Laneway Housing (LWH) in Single Family Areas Issues and Options. Retrieved September 2010 from http://vancouver.ca/commsvcs/ecocity/lane wayhousing.htm

Clark, H; Brody, D. (Eds.). (2009). Design studies: A reader. Oxford; New York: Berg.

Dault, G.M. (2004, Aug.). Inverse City: Urban density and the possibilities of a city's laneways and hidden conduits are explored. Canadian Architect. Retrieved February 6, 2010 from http://www. canadianarchitect.com/issues/story.aspx?aid=1000191939.

Derren. (2009, Jan.). Laneway Housing: Back Alley homes to ease pressure off tight rental market. Mega Phone: Vancouver's Street paper. Retrieved February 16, 2010 from http://www.megaphonemaga zine.com/content/laneway_housing_back_alley_homes_could_ease_pressure_tight_rental_mar ket.html. 

DeWolf, C. (2007, Feb.). Toronto's Innovative Infill. Urban Photo. Retrieved February 14, 2010 from http:// www.urbanphoto.net/blog/2007/02/16/torontos-innovative-infill/.

Duran, S.C. (Ed.). (2009). PreFab houses. Spain: Evergreen.

Farquharson, V. (2009, Aug.). The Next Frontier: Laneways. The Financial Post. Retrieved February 12, 2010 from http://www.financialpost.com/news-sectors/energy/green-energy/greenhomes/story.html?id=1939793\#ixzzOfksBcmRI.

Ford, Larry R. (2000). The Spaces between Buildings. Baltimore and London: The Johns Hopkins University Press.

GHK International Ltd (2000). The Future of Downtown Toronto. Retrieved August 2010 from www.toronto.ca/torontoplan/downtown_future.pdf.

Goldman, L. (2009, July). Vancouver Laneway Housing. Vancouverresidence.com. Retrieved February 16, 2010 from http://www.vancouverresidence.com/market-insights/2009/07/ vancouver-laneway-housing.html.

Hayes, Derek. (2008). Historical Atlas of Toronto. Vancouver: Douglas \& McIntyre.

Hume, C. (2009, Oct.). Toronto's 2,400 laneways offer great potential for development. The Toronto Star. Retrieved February 13, 2010 from http://www.thestar.com/news/insight/article/707696--toron to-s-2-400-laneways-offer-great-potential-for-development.

Kerr, D; Spelt, J. (1965). The Changing Face of Toronto: A Study in Urban Geography. Ottawa: Queen's Printer.

Kunz, M.N; Galindo, M. (2005). Modular houses. Austria: Avedition.

Latham, D. (2000). Creative re-use of buildings. Volume two. United Kingdom: Donhead Publishing Ltd.

Lemon, J. (1985). Toronto Since 1918: An Illustrated History. Toronto: James Lorimer \& Company, Publishers and National Museum of Man, National Museums of Canada.

Monsebraaten, L. (2004, Jan.). Life in suburbia costs more than you'd think. Retrieved February 13, 2010 from http://www.walkablestreets.com/suburbcost.htm.

Monsebraaten, L. (2007, Sept.). Driving to Green Buildings: The transportation energy intensity of buildings. Retrieved February 13, 2010 from http://www.walkablestreets.com/greenbuilding.htm.

Mostaedi, A. (2006). Great spaces: Flexible homes. Barcelona: Links Books.

Ng, E. (2010). Designing High Density Cities for Social and Environmental Sustainability. London: Earthscan.

[No Author Given]. (2009, July). Laneway housing approved by Vancouver council. CBC News. Retrieved February 16, 2010 from http://www.cbc.ca/canada/british-columbia/story/2009/07/29/bcvancouver-lane-way-housing.html. 

Norden, D. (Ed). (1988). Reweaving the urban fabric: Approaches to infill housing. New York: Princeton Architectural Press.

Ontario Smart Growth.(2003). Shape the future: Central Ontario Smart Growth Panel. Ontario: Ministry of Infrastructure.

Orr, D.W. (2002). The nature of design. Oxford ; New York : Oxford University Press.

Ray, M; Sherman, R; Zardini, M. (Eds). (1999). The Dense-city: dopd la dispersion: after the sprawl. Milano: Electa.

Rybczynski, W. (1986). A short history of an idea of home. New York: Penguin Books.

Sewel, J. (1993). The Shape of the City. Toronto Struggles with Modern Planning. Toronto: University of Toronto Press.

Schneider, T. \& Till, J. (2007). Flexible housing. Oxford: Elsevier.

Scheurer, J. (2007). Compact City Policy: How Europe rediscovered its History and Met Resistance. Urban Reinventors Paper Series. Retrieved October 2010 from http://www.urbanreinventors.net/ 2/scheurer/scheurer-urbanreinventors.pdf.

Town, H. (1974). Albert Franck: Keeper of the Lanes. Toronto: McClelland and Stewart Limited.

The Green Door Alliance (2001). Sprawl - Smart Growth Report. Retrieved in January 2010 from http:// www.thegreendooralliance.ca/pubs.html .

Verge, S. (2005). Changing lanes: a conversation with Jeffery Stinson. In J. McBridge. \& A. Wilcox. (Eds.), Utopia. Towards a new Toronto (pp. 86-95). Toronto: Coach House Books.

Villagomez, E. (2009, April). The future of urban planning is open source. Replace Magazine. Retrieved August 2, 2010 from http://regardingplace.com/?p=3942.

Virilio, P. (1997). The overexposed city. In N. Leach (Ed.), Rethinking architecture: A reader in cultural thinking. (pp. 9-27). London ; New York : Routledge.

Wise, L; Gould, A. (2000). Toronto Street Names: An Illustrated Guide to their Origins. Willowdale, Ontario: Firefly Books Ltd.

Wolch, J. (2010, February). Places to Play: Environmental justice and the distribution of urban parks and recreation in Los Angeles. arcCA. P15-20.

Woo, L. (2003, June.). Ontario Smart Growth. Making Smart Growth a Reality: Putting Principles into Practice. Retrieved February 15, 2010 from http://www.smartgrowth.on.ca/index.htm.

Wright, G. (2009). City of Toronto. Toronto Official Plan 2009. Retrieved February 15, 2010 from http://www. toronto.ca/planning/official_plan/pdf_chapter1-5/chapters1_5_oct2009.pdf. 